University of Louisville

ThinkIR: The University of Louisville's Institutional Repository

Electronic Theses and Dissertations

8-2013

\title{
The rhetoric of Africa : historical turns in constructing a continent, 1780-1890.
}

Dexter Peck Mahaffey

University of Louisville

Follow this and additional works at: https://ir.library.louisville.edu/etd

\section{Recommended Citation}

Mahaffey, Dexter Peck, "The rhetoric of Africa : historical turns in constructing a continent, 1780-1890." (2013). Electronic Theses and Dissertations. Paper 884.

https://doi.org/10.18297/etd/884

This Doctoral Dissertation is brought to you for free and open access by ThinkIR: The University of Louisville's Institutional Repository. It has been accepted for inclusion in Electronic Theses and Dissertations by an authorized administrator of ThinkIR: The University of Louisville's Institutional Repository. This title appears here courtesy of the author, who has retained all other copyrights. For more information, please contact thinkir@louisville.edu. 


\title{
THE RHETORIC OF AFRICA: HISTORICAL TURNS IN CONSTRUCTING A CONTINENT, 1780-1890
}

\author{
By \\ Dexter Peck Mahaffey \\ B.A., Middlebury College, 1993 \\ M.A., Bread Loaf School of English, 1998
}

\begin{abstract}
A Dissertation
Submitted to the Faculty of the

College of Arts and Sciences of the University of Louisville

in Partial Fulfillment of the Requirements

for the Degree of
\end{abstract}

Doctor of Philosophy

Department of English

University of Louisville

Louisville, Kentucky

August 2013 
Copyright 2013 by Dexter Peck Mahaffey

All rights reserved 



\section{THE RHETORIC OF AFRICA: HISTORICAL TURNS IN CONSTRUCTING A CONTINENT, 1780-1890 \\ By \\ Dexter Peck Mahaffey \\ B.A., Middlebury College, 1993 \\ M.A., Bread Loaf School of English, 1998 \\ A Dissertation Approved on}

August 7, 2013

By the following Dissertation Committee:

Dr. Carol Mattingly, Dissertation Director

Dr. Glynis Ridley, Committee Member

$\overline{\text { Dr. Stephen Schneider, Committee Member }}$

Dr. Beth Willey, Committee Member

Dr. Wyatt MacGaffey (Haverford College), Committee Member 


\section{DEDICATION}

For Iain and Kai

and always, for Era 


\section{ACKNOWLEDGMENTS}

My utmost gratitude goes to Dr. Carol Mattingly, longtime advisor, and director of this project from its inception years ago through to the end. Her steadfast encouragement and enthusiasm, her sharp critical eye, and her vision of a field of Rhetoric inclusive of work such as this have been humbling. I am also grateful to the other members of the committee, Dr. Beth Willey, Dr. Stephen Schneider, and Dr. Glynis Ridley, whose insights and critiques at key moments have pushed the work forward to its conclusion. For his frankness, generosity with his long and extensive expertise in African Studies, and willingness to be involved, I am grateful to Dr. Wyatt MacGaffey of Haverford College, and equally so to Dr. Susan Herlan, whose encouragement was ceaseless, and whose friendship and hospitality here and in Ghana are the stuff of legend for a reason. And lastly thanks goes to my extended family whose unflinching support, sympathy and empathy, patience, and interest in the project both allowed it and made it worth the trouble: they are graciousness. 


\section{ABSTRACT \\ THE RHETORIC OF AFRICA: HISTORICAL TURNS IN CONSTRUCTING A CONTINENT, 1780-1890 \\ Dexter Peck Mahaffey}

August 7, 2013

This dissertation examines historical rhetoric about Africa in British and American writings between the beginnings of the Abolition period and the 1884 Berlin Conference at which the continent was divided by colonial powers. Tracing rhetorical trends of travel writers and their constituents through the explorations of the continent, it demarcates two turns in the way Africans and Africa were constructed rhetorically. In the process it reveals a $19^{\text {th }}$-century evolution from depicting Africa largely in terms of its viability for commerce and reception of European culture, to an Africa fallen into darkness, to Africa as the Dark Continent, permanently fixed in a savage darkness. These rhetorical turns are examined through the theoretical frameworks of rhetorical imperialism and rhetorical sovereignty.

Chapter I explores the creation of Sierra Leone for resettling freed British blacks and the varied, at times contradicting, rhetoric lacking in uniform vision of the continent or its people other than a general trend of focusing on the viability of Africa as a site for British post-slavery endeavor and an ambivalent view of African cultural inferiority. Chapter II explores the American creation of Liberia, revealing a specific rhetoric of Africa as benighted, fallen, and degraded. This chapter demonstrates the rhetorical turn 
that occurred between the establishment of Sierra Leone and subsequent founding of Liberia, when the importance of Christian faith came to trump all other concerns for evaluating and characterizing Africa. Chapter III contains two case studies of the extent to which such rhetorical imperialism can be contested, one of Samuel Crowther, a Nigerian recaptive settled in Sierra Leone who then returned to Nigeria years later as an explorer, and another of Martin Delany, a free African American who traveled to Nigeria to seek an emigration site for African Americans fleeing slavery. Chapter IV juxtaposes the rhetorical work of Henry Stanley and his reports on explorations in Central Africa with the simultaneous rhetoric of the Great Zimbabwe debates. In so doing, the arc of rhetorical development since the Sierra Leone era is traced, complicating contemporary definitions of the Dark Continent and suggesting its continued limitation on African rhetorical sovereignty today. 


\section{TABLE OF CONTENTS}

ACKNOWLEDGEMENTS....................................................

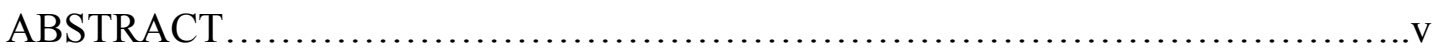

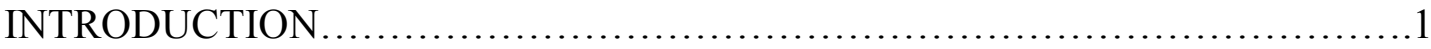

CHAPTER I: The Discovery of Sierra Leone: Britain Goes Exploring in West

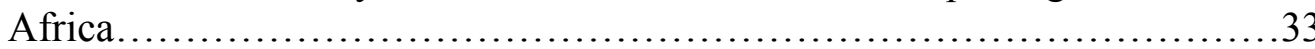

I. Henry Smeathman, the Committee for the Black Poor, and a Plan for Sierra Leone. 36

II. In the Eye of the Public: the Establishment of Sierra Leone and

The Times

III. Sierra Leone as Company and the Rhetoric of the Corporate Document

IV. Success in Africa: The Times' Ongoing Relationship with Early Sierra Leone............................................75

CHAPTER II: Liberia and the Christian Turn in the Rhetoric of Africa.

I. The Founding of Liberia. 93

II. The Lexicon of Africa: A Focus on American Writing at the Occasion of Liberia. 109

III. American Explorers in Africa: American Colonization Society Expeditions, 1818-1821

CHAPTER III: Diasporant Rhetorical Constructions: The Limits of Rhetorical Sovereignty in the Travel Writings of Samuel Crowther and Martin Delany...136

I. Samuel Crowther's Transnational African Experience. 140

II. Martin Delany's Transatlantic African Experience.... 156

CHAPTER IV: The Second Rhetorical Turn: The Dark Continent, Inhumanity, and the Place That Never Could. 
I. Rhetoric of Africa after Liberia: Politics, Science, and Unchecked Racism.......................................................194

II. The Africa That Never Could: Dark Continent Rhetorics and Great Zimbabwe

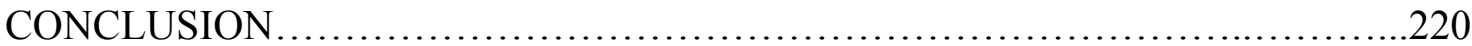

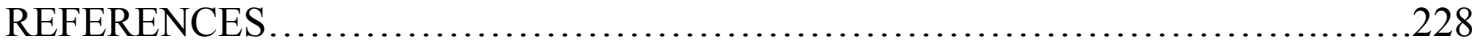

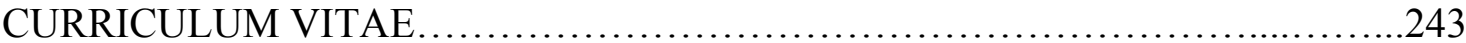




\section{INTRODUCTION}

After visiting Africa for the first time in 2006, culinary-adventurer Anthony Bourdain introduced it to his television audience by saying it was "once known as the Dark Continent because so little was known about it." In early 2013, the BBC aired a new television series entitled, "Africa: Eye to Eye with the Unknown," in which the program presents “the world's wildest continent as you've never seen it before...venturing into genuinely unexplored places and capturing never-seen-before behavior." The New York Times review quoted in the video's promotions proclaims that the BBC program "turns the dark continent bright.", The ability of contemporary media to depict Africa as a Dark Continent, wild, unknown, and unexplored assumes an audience literate with such a metaphor. That literacy did not come to be through a constant, repeated use of the term over the course of several hundred years, but rather through nuanced shifts in rhetoric taking place over the course of a century of western expeditions to Africa, between the beginnings of the Abolition movement in the 1770s and the division of the continent by colonial powers at the 1884 Berlin Conference. Over the course of that period, the rhetoric of Africa made two major rhetorical turns that

\footnotetext{
${ }^{1}$ Anthony Bourdain, No Reservations. The Travel Channel. Season 2, Episode 10, 3 September 2006.

${ }^{2}$ Africa: Eye to Eye with the Unknown. 2013. London: BBC Home Entertainment, 2013. DVD.
} 
ended with the creation of the Dark Continent metaphor, one understood at the time to mean something quite different from its connotations today.

When the Clapham Sect created Sierra Leone as a dumping ground for freed British slaves in the 1780 s, British writers and explorers depicted the continent through a broad set of differing rhetorics that in general had to do with Africa's viability for postslavery commercial and abolitionist interests. And while British writing typically portrayed Africans as overall somewhat inferior, they did not develop a specific, consistent trend for depicting them or characterizing the continent. Unlike in the decades to follow, the words Africa and African were not modified by any consistent adjectives or marked by other pervasive qualifiers. This changed in the early- $19^{\text {th }}$ century, once Sierra Leone was well-established, when the American Colonization Society invented Liberia: at this point a specific, focused rhetoric came into regular use among various and often competing stakeholders in discussions of the continent. The pervasive rhetoric in this period described the continent using the specific terms benighted, fallen, and degraded, and characterized it as an Africa fallen from a once-grand past. This shift marked the first rhetorical turn.

In the following decades, however, as the Liberian colonization scheme's failure suggested that grand African past to be mythical, racial tension in the U.S. increased; meanwhile, differing claims of evolutionary science further complicated understandings of race. By the latter half of the $19^{\text {th }}$ century, a newer, equally specific and focused rhetoric pervaded characterizations of Africa and Africans. The prior rhetoric of an Africa fallen into darkness evolved into one of an always already dark Africa, and of savage, cannibalistic Africans distanced biologically from Caucasians according to 
theories of polygenism: thus the arrival of the rhetoric of the Dark Continent, and the second rhetorical turn.

These shifts in the way English speakers and writers outside of the continent construct it — from an Africa not considered in terms of light and dark, to a darkened Africa, to a Dark Africa — are rhetorical: underneath these metaphors are denotations of civil fixedness or mobility, potential or incapacity, the ongoing manipulation and maintenance of which have maintained discursive dominance over the continent. That the rhetoric is employed by way of simple adjectives and elaborations thereof eases a conflation of these distinct terms, such that both their historical progression and the distinction between them has blurred. Thus it is that dictionaries of today can argue that the term "Dark Continent" was the $19^{\text {th }}$-century term for Africa and in so doing bury those rhetorical shifts that actually populated that century. Furthermore, suggesting-as Bourdain and the $\mathrm{BBC}$ do - that adjectives of darkness have to do with Western ignorance about Africa is a further obfuscation of $19^{\text {th }}$-century rhetorical history, which instead argues that the different associations of darkness with Africa have sharply distinct meanings based on Western beliefs about the place and its people at different stages in the rapidly evolving $19^{\text {th }}$-century dynamic between Africa, Britain, and the U.S.

At stake in unpacking the rhetorical history of Africa between the 1780s-1890s is the ongoing use of the quintessential term Dark Continent as well as its associated rhetorics today, such as the New York Times' refrain that Africa is a place of darkness to which the West must bring light. The continuing rhetorical location of Africa in a state of disadvantage and need simultaneously reiterates old notions of inferiority if not more mercenary characterizations, ones that arguably allow for ongoing inequitable and 
abusive relationships. As Alastair Pennycook argues, it "should not be seen as a forgotten era in the past but rather as the context in which current ideas were framed." That the rhetoric of Africa employed today echoes that of 130 years ago suggests the need for a careful analysis and critique of what Patrick Brantlinger calls the "genealogy" of such rhetoric, so that we know what we actually mean when we depict the continent in this way. Adjectives here reveal the rhetorical turn, their metaphorical nature upon close examination and comparison revealing (rather than obscuring) the rhetorical intent, in the service of which the metaphors are employed.

Such work has begun in both broad ways-looking at grand and long-term inventions and constructions of Africa by those outside it—and through narrow lenses that examine the precise rhetoric of the Dark Continent itself. This dissertation, grounded in the former, seeks to engage the specifics of the latter. For while Brantlinger and others have explored the significance of the rhetoric of the Dark Continent at its creation in the late-1800s and its use ever since, the progression of terms leading up to the Dark Continent — in which the differing understandings of Africa and Africans came into contest over the course of the late- $18^{\text {th }}$ century through the first three-quarters of the $19^{\text {th }}$ century — has yet to be explored and analyzed. This dissertation seeks to intervene in the greater scholarship by detailing and elaborating the two rhetorical turns that lead to the Dark Continent rhetoric, turns that reveal more dynamic rhetoric of Africa than has previously been attributed to this period and also reveal a clearer understanding of what was meant by notions of darkness, as well as the problems of their ongoing use. What is called for is a careful consideration of the history of the use of English in relation to the

\footnotetext{
${ }^{3}$ Pennycook, English and the Discourses of Colonialism, 23.
} 
continent: in short, what the language has done with Africa between the beginnings of Abolition and when the land grab of colonialism was formalized.

Before proceeding, it is important to establish the theoretical framework grounding the analysis of this project. From a theoretical standpoint, the question of rhetorical constructions of Africa and Africans can be viewed as a case study of what Scott Lyons refers to as rhetorical imperialism, a compatriot to what Robert Phillipson describes as linguistic imperialism.

Scott Lyons's discussion of the concept "rhetorical sovereignty," in his article on American Indians and writing, answers the dilemma Jacqueline Jones-Royster has posed over the control of under-represented voices and who speaks for them (i.e., themselves or others). ${ }^{4}$ Lyons argues that for peoples who have historically been victims of injustice involving (mis)representation by others, the antidote is the control of that rhetoric about themselves. "Sovereignty is the guiding story in our pursuit of self-determination," writes Lyons, "the general strategy by which we aim to best recover our losses from the ravages of colonization: our lands, our languages, our cultures, our self-respect." ${ }^{, 5}$ Under that broad umbrella of sovereignty, "rhetorical sovereignty," then, is the "inherent right and ability of peoples to determine their own communicative needs and desires in this pursuit, to decide for themselves the goals, modes, styles, and languages of public discourse."

\footnotetext{
${ }^{4}$ Jones-Royster, "When the First Voice You Hear is Not Your Own."

${ }^{5}$ Lyons. "Rhetorical Sovereignty," 449.

${ }^{6}$ Ibid., 449-50.
} 
Lyons's term here is a response to a specific form of injustice- the opposite of rhetorical sovereignty: it is "rhetorical imperialism," which he explains is "the ability of dominant powers to assert control of others by setting the terms of debate. These terms are often definitional — that is, they identify the parties discussed by describing them in certain ways." "7 As with other struggles for dominance, this control of defining terms is neither to the benefit of nor meant to flatter the recipient; rather, Lyons explains, it is "people being completely redefined by their interlocutors: a ward or pupil—that is, a child—is quite a different animal than a fellow nation in the community of sovereigns." Such redefinition is essential to this theory of rhetorical imperialism because, Lyons argues, "He who sets the terms sets the limits." analysis of historical rhetoric of Africa, which reveals a sharply precise, positivistic selection of terms to depict the continent, terms that effectively limit perceptions of the continent and thus mount a challenge to its sovereignty, rhetorical or otherwise. For as Lyons makes clear, a limit on rhetorical sovereignty indicates a limit on sovereignty overall. Transferring Lyon's model of historical European rhetorical imperialism towards Native Americans to another location where Europeans employed the same tool in the service of overall imperialism is a logical and useful tool for discerning the intricacies of that imperialism, specifically in order to understand where and how it limited rhetorical sovereignty.

\footnotetext{
${ }^{7}$ Ibid., 452.

${ }^{8}$ Ibid.

${ }^{9}$ Ibid.
} 
When Robert Phillipson explores the concept of linguistic imperialism, he focuses on English linguistic imperialism, particularly as carried out in Africa. He suggests that "a working definition of English linguistic imperialism is that the dominance of English is asserted and maintained by the establishment and continuous reconstitution of structural and cultural inequalities between English and other languages." ${ }^{10}$ As a correlate of rhetorical imperialism, Phillipson's focus does not complicate Lyons's, but rather clarifies a particular fact, which is that it is speakers and writers of English who have done much of that rhetorical imperialism to which Lyons refers. Pennycook further suggests a connection, pondering the ways "in which certain discourses adhere to English," ${ }^{11}$ that is, something intrinsic about the language itself that lends it more to imperialist practice than other languages. In so doing, he would "situate English language teaching within the broader discourse of colonialism" and so parallel his assessment of it to Steiner's of German after the Holocaust. Pennycook suggests that English during colonialism operated similarly in that "words were committed to saying things that no human mouth should ever have said and no paper made by man should ever have been inscribed with." 12 After first posing the paradox, "Could it not be the case that it is easier to articulate certain ideas in certain languages?" he suggests that “connections do not lie so much in 'the marrow' of English but in the intimate relations between the language and the discourses of colonialism." 13 The power embedded in the use of language that Pennycook and Phillipson describe informs the tension Lyons

\footnotetext{
${ }^{10}$ Phillipson, Linguistic Imperialism, 47; italics in original.

${ }^{11}$ Pennycook, English and the Discourses of Colonialism, 5.

${ }^{12}$ Ibid., 3.

${ }^{13}$ Ibid., 4.
} 
depicts, for rhetoric is accomplished in the world of a specific language and its manipulations. That rhetorical imperialism is enacted in a language also forced upon the imperialized people in the case of both Native Americans and Africans exacerbates the power of that rhetoric, for it is thereby consumed and potentially re-enacted by those literate in the imperializing language. ${ }^{14}$

The interaction in Africa between English linguistic imperialism and rhetorical imperialism in English - that many Africans who have been subjugated rhetorically have also had literacy in English intentionally imposed on them—is the subject of much postcolonial theory. ${ }^{15}$ And extending that theoretical analysis to the period before the Berlin Conference - before the colonization of the continent as a whole - allows for an examination of the rhetorical imperialism of British and American authors writing about Africa and the level to which African writers at the time resisted such imperialism and the level of rhetorical sovereignty they attained. As Lyons argues, "At stake in this discussion are the peoples defined by the writing itself: thus one important tenet of rhetorical sovereignty would be to allow [them] to have some say about the nature of their textual representations." ${ }^{, 16}$ Historical rhetoric about Africa—particularly the rhetoric of Diaspora writers in the midst of the rhetorical turns under scrutiny here-repeats Lyons' model of tension between rhetorical imperialism and sovereignty and indicates some of the limits to which rhetorical sovereignty can be achieved. For when Lyons

\footnotetext{
${ }^{14}$ The nuances of linguistic imperialism and resistance to it continue to be explored through the work of Kachru, Canagarajah, Ngugi, and others, in addition to Pennycook and Phillipson.

${ }^{15}$ Again, for example, return to Pennycook, who writes, "How is it that this language, English, can so easily confer civilization on these [populations], while at the same time it is this very language that is constructing [them] racially?....English is both the language that will apparently bestow civilization, knowledge and wealth on people and at the same time is the language in which they are racially defined" (English and the Discourses of Colonialism, 4).

${ }^{16}$ Lyons, "Rhetorical Sovereignty," 458.
} 
suggests that "rhetorical sovereignty requires above all the presence of [their] voice, speaking or writing in an ongoing context of colonization and setting at least some of the terms of the debate, ${ }^{117}$ he leaves open how many "some" is, which is to say how free of someone else's rhetoric one must be, in order to achieve sovereignty.

Lyons, Phillipson, and Pennycook collectively establish a theoretical framework into which to situate an analysis of historical rhetorics of Africa, particularly in the way they clarify the political nature of that rhetoric, both historical and contemporary. And while the field of Rhetoric itself has not been explicitly applied on a regular or extensive basis to considerations of Africa, ${ }^{18}$ a scholarly conversation of a precisely rhetorical nature has occurred in recent decades, creating a robust and lively debate over constructions, representations, inventions, and reinventions of Africa, carried out through the fields of philosophy, history, anthropology, and even museum curatorship. This scholarship on how the West operates towards Africa typically asserts the problem that Africa is constructed as a whole and uniformly, which is to say that Africa is constituted as Africa by the world outside. ${ }^{19}$ The work of these texts is to elaborate the process and nuances of this construction, which varies according to the tools used for analysis. The diversity of scholarly fields brought to bear on this dilemma suggests that if Africa as a holistic, uniform entity is an invention-particularly a conceptual invention of the

${ }^{17}$ Ibid., 462.

${ }^{18}$ Much in the way that Lyons was one of the early writers to do so on writing and Native Americans from within the discipline of Rhetoric.

${ }^{19}$ See, for example, Annie Coombes, who writes of "Africa, as a concept as much as a geographical designation" (Reinventing Africa, 2). 
West $^{20}$ - then understanding the way in which it was conceptualized and invented as well as the progression of that work is crucial.

V.Y. Mudimbe's The Invention of Africa examines how Africa has been characterized historically, particularly since contact in the late-1400s. Specifically, he sets out "to study the theme of the foundations of discourse about Africa," 21 in the same vein of Foucault's theory on discourse and power. He focuses on exploring a bifurcated sense of discourse, which is to say non-African constructions of Africa and African realities that contest those constructions. Mudimbe's interest consists then of the "complex questions about knowledge and power in and on Africa,"22 and to that end, he focuses primarily on art, discussions of African crafts, travel writings, and eventually anthropology (at which point it becomes a critique of the failings of anthropology as a discipline, much like Desai's and Derricourt's similar efforts, discussed below).

By examining certain Rubens, Rembrandt, and Rigaud $17^{\text {th }}$-century paintings as well as Linneas's 1735 Systema Naturae, Mudimbe suggests that there is a "new epistemological foundation...functioning in the West" which consists of "theories of diversification of beings, as well as classificatory tables, explain[ing] the origins of constructing taxonomies." ${ }^{23}$ Therein lies a notion that the West was collectively categorizing Africans in a racialized sense for the first time - in art, science, and elsewhere - and that such racialization served to explain their positions in relation to each other - to be precise, the inferiority of Africans to the West. "The African," Mudimbe

\footnotetext{
${ }^{20}$ One echoing the invention of race, as critical race theory has argued.

${ }^{21}$ Mudimbe, The Invention of Africa, xi.

${ }^{22}$ Ibid.

${ }^{23}$ Ibid., 9.
} 
explains, "has become not only the Other who is everyone else except me, but rather the key which, in its abnormal differences, specifies the identity of the same." ${ }^{24}$ There is a nuance here, however, that is essential to Mudimbe's point about the importance of the $17^{\text {th }}$ and $18^{\text {th }}$ centuries, in terms of the nature of perceptions about Africans. By the 1700s, condescending or negative views of Africans, he argues, were already well established: "The distinction between 'savage Negro' and 'civil Mohometan,' and the commentaries on the Africans' indolence, their unbridled passions, and their cruelty or mental retardation were already there. ${ }^{, 25}$ But the difference between negativity and racialization, he argues, has to do with that epistemological approach, which is to say, a scientific, evidentiary way of thinking about Africans. In particular,

Explorers just brought new proofs which could explicate "African inferiority." Since Africans could produce nothing of value; the technique of Yoruba statuary must have come from Egyptians; Benin art must be a Portuguese creation; the architectural achievements of Zimbabwe was due to Arab technicians; and Hausa and Buganda statecraft were inventions of white invaders. ${ }^{26}$

Mudimbe's effort, then, is to inscribe a line around what made full-blown colonialism in the latter- $19^{\text {th }}$ century possible.

Such discourse that shifts its terms for constructing the African from as other to as inferior was easily extended, Mudimbe argues, to what was to be done with an inferior continent back on the evolutionary progression one step from European society. The explorers, from Mungo Park to Henry Stanley, who produced texts about their times in Africa in the end actually "speak about neither Africa nor Africans, but rather justify the

\footnotetext{
${ }^{24}$ Ibid., 12.

${ }^{25}$ Ibid., 13.

${ }^{26}$ Ibid.
} 
process of inventing and conquering a continent and naming its 'primitiveness' or 'disorder,' as well as the subsequent means of its exploitation and methods for its 'regeneration." ${ }^{\prime 27}$ Exploring the theories of colonization as being in the service of capitalism and moving in tandem with it, Mudimbe further assesses the field of anthropology as in turn doing the same work for colonization; for example, Mudimbe defines anthropology as the cataloging of "the distance separating savagery from civilization on the diachronic line of progress. ${ }^{28}$

Mudimbe shifts from assessing the way in which Africa has been repeatedly and consistently invented to refuting criticisms surfacing in the West, defending Africa from that discourse. For example, he assails Carl Sagan's incredulity towards the Dogons' astronomical abilities, in turn promoting how they possess a sophisticated science not recognized by Sagan due to his own inability to do so, an analysis that exemplifies Lyons's vision of attempts at rhetorical sovereignty.

As with Mudimbe, it would be difficult to speak of the scholarship critiquing discourse on Africa without mentioning Kwame Anthony Appiah. His In My Father's House: Africa in the Philosophy of Culture begins with the chapter "The Invention of Africa." Appiah might more accurately be classed as a critical race theorist, particularly due to his critique of ideas of race in this text. However, his move to debunk the holistic consistencies upon which notions of racism rely effectively makes the same critique other authors in the broader field under discussion here make about conceptions of Africa, which is that such conceptions rely on a universal characterization of the continent and

\footnotetext{
${ }^{27}$ Ibid., 20.

${ }^{28}$ Ibid., 15.
} 
the people living there. Appiah's first move is to unpack racialism, a doctrine he suggests argues for "heritable characteristics, possessed by members of our species, which allow us to divide them into a small set of races, in such a way that all the members of these races share certain traits and tendencies with each other that they do not share with members of any other race." ${ }^{29}$ Racialism, he argues, is a belief not only that these characteristics exist, but also that they collectively "constitute... a sort of racial essence" that "account [s] for more than the visible morphological characteristics." ${ }^{, 30} \mathrm{~A}$ belief in a racial essence is a belief that race is an essential quality of self. And so Appiah defines racism as an ideology which relies on racialism as, in his words, its presupposition. $^{31}$

Part of the problem Appiah outlines - and the most relevant aspect of his work here- - is that this concept of racial essence simplifies and universalizes Africa: to be African is to be black, and to be black follows from an "assumption that the Negro was a single race. ${ }^{, 32}$ What took hold in the early colonial mind in Africa of the late- $19^{\text {th }}$ century was not an oversimplification of African diversity in the service of racist attitudes, but a holistic acceptance of interacting with and identifying Africa as a site of race rather than as possessing various and diverse discourses. "There are only two real players in this game," Appiah claims, "us, inside; them, outside. That is all there is to it." ${ }^{, 33}$ Such a

\footnotetext{
${ }^{29}$ Appiah, In My Father's House, 13. See also the discussion of polygenism - the historical precursors to what Appiah terms "racialism"-in the final chapter here.

${ }^{30}$ Appiah, In My Father's House, 13.

${ }^{31}$ Ibid., 13-14.

${ }^{32}$ Ibid., 20.

${ }^{33}$ Ibid., 56.
} 
"covert universalism," writes Appiah, "within the rhetoric of particularism rears its head, for it is surely Eurocentric presumption to insist on a correspondence within African culture to the institutionalized discourses of the West." ${ }^{\text {,34 }}$ He further argues, "The peoples of Africa have a good deal less culturally in common than is usually assumed."35

Referring to Paulin Hountondji's depiction of this scenario as "unanimism," Appiah further elaborates that what was constructed in the $19^{\text {th }}$ century was a belief not only "in the existence of a peculiar African form of thinking but also... a belief in special African contents of thought. ${ }^{, 36}$ Anecdotally, Appiah discusses his inability, as a Ghanaian, to have a sense of understanding of Botswana, a landscape and culture utterly foreign to him. As he writes,

It is easy to see how history can make you, on the one hand, say, a citizen of Ivory Coast or of Botswana; or on the other, say, anglophone or francophone. But what, given all the diversity of the precolonial histories of the peoples of Africa, and all the complexity of colonial experiences, does it mean to say that someone is African? ${ }^{37}$

At the heart, then, of Appiah's work, in spite of its chief example of the problems of a concept of race and its focus on the time periods of colonialism and postcolonialism, is a firm commitment to complicate the simplistic notions of a singular, uniform Africa and singular, uniform, identical Africans. In seeking to unpack contemporary notions of race, he does the same work Mudimbe seeks to do in terms of resisting the ease with which Africa is constructed rhetorically.

\footnotetext{
${ }^{34}$ Ibid., 68.

${ }^{35}$ Ibid., 17.

${ }^{36}$ Ibid., 24. Part of the work of this dissertation is to elaborate on Appiah's (and others') somewhat broad use of the term " $19^{\text {th }}$ century," and in so doing delineate the progression of the construction that he describes.

${ }^{37}$ Ibid., 25.
} 
Guarav Desai follows directly both Appiah's and Mudimbe's works but also diverges from their efforts by specifying the connection between discourse and rhetoric. In Subject to Colonialism: African Self-fashioning and the Colonial Library, he writes, "Discourses...do things with and in the world, and their very entry into the social is a subject of great importance to students of culture. The question to ask of a discourse is not so much what it says but what it does." It is "reading for 'rhetoric' rather than a reading for 'sense." "'38 Desai's text operates much as Mudimbe's, not only referencing it specifically but also making similar moves to critique anthropology's service to (and generation from) colonialism; but it is the rhetorical approach that he adds to this field of study that is most useful here. It forces a focus on textuality, and it grounds the examination of those texts in the tools appropriate to this particular effort- the unpacking and decoding of how Africa was constructed in the West through the written word.

Desai's first move is to put terminology to what Appiah hints at with the term unaminism (a sense that one can speak of Africa uniformly, as if it were homogenous). “Africanism," writes Desai, "like Said's Orientalism, was a discourse that permeated the lives of both the observed as well as the observers - the colonized as well as the colonizers - and both participated, albeit unequally, in the constitution of the colonial library.. ${ }^{39}$ Desai, then, is interested both in what was written about Africa but also the way in which writers from Africa under colonialism were at times complicit in the rhetorical construction of Africa (such as what he calls "native" anthropologists as discussed below). Desai, however, does not equivocate, clarifying that "to say this is not

\footnotetext{
${ }^{38}$ Desai, Subject to Colonialism, 5.

${ }^{39}$ Ibid., 7.
} 
to erase the distinction between the colonizer and the colonized but to understand the colonial library as itself an important terrain of colonial tension and struggle, ${ }^{, 40}$ strongly echoing the question of rhetorical sovereignty posed by Lyons.

Following Mudimbe's analysis of the power at play in this discourse, Desai argues that the complications of racialized thinking are perhaps not what Appiah suggested — that they are utterly inaccurate or impracticable — but rather that it was the failure of the capacity of race to serve as an effective organizing factor for colonialism. It is here that Desai argues for the entry of rhetoric into colonial practice:

If colonialism was at its heart about the exertion of an external political powerreal or imagined - over an indigenous community, it was no less also about the establishment of a rhetorical power in the same domain... The ability to call the shots of "sameness" ("they are like us") or "difference" ("they are not like us") in differently motivated circumstances, and to call these shots forcefully, was the crux of the rhetorical game. ${ }^{41}$

Race, Desai argues, is not "originary" but a matter of colonial practice, a tool for certain times and places, and one that is not only inconsistently utilized or applied, but also that at times is not apparent whatsoever.

Desai's work progresses through Social-Darwinist explanations of the meaning of primitive cultures in relation to European ones and how that theoretical framework informed colonial practices, especially theorizing and strategizing eugenics, developing education policy and pedagogy, and legitimizing anthropology as a field. In examining the colonial library in these disciplines, he makes close readings of a series of texts meant to be "not exhaustive but "symptomatic,",42 a useful practice as well as guideline when
${ }^{40}$ Ibid.
${ }^{41}$ Ibid., 20.
42 Ibid., 79. 
considering a massive historical body of work. In particular he seeks writings that argue for supposed failures in cognitive development in Africans and the perceived falloutwritings that employed social-Darwinist distinctions between cultures to argue for biological inferiority in brain development of lesser races (efforts such as Morton's, Dart's, and others), writings that justified racialized thinking and used it as a rhetorical tool to enable the transition from empire to colony.

Desai's critique of anthropology, or more specifically the writings of anthropologists, is sourced in "the obvious and indisputable fact that anthropology as a discipline gained tremendously from the colonial project." ${ }^{, 43}$ He elaborates the workings of these gains, arguing,

Anthropology's (colonial?) nostalgia, which quietly turns to the African to teach "us" about our own loss, repeats the troubling trope of the noble savage. In doing so, it insists on inventing the African space as a primordial, pre-economic space, where everyone helped each other through the sheer goodness of their hearts (again the noble savage), without any economic calculations whatsoever. In such a sharply divided world, "they" have symbols (or at most "symbolic capital") while in our own fallen state, "we" have economy. ${ }^{44}$

Desai argues that even "native" anthropologists (e.g., Kenyatta and Kenya, Akiga and the Tiv) only serve to do what Mudimbe and Appiah critique in African literature - to defend Africa rather than assault the West—-because they accept the rhetoric of Africa constructed in the discourse of Africanism and in so doing reflexively advance it. Desai's critique of anthropology, and his justification for revisiting it as a topic after Mudimbe, is its nature as a rhetorical device. Rather than critiquing anthropology as being complicit in colonialism, Desai wants to examine what it does discursively: the

\footnotetext{
${ }^{43}$ Ibid., 98 .

${ }^{44}$ Ibid., 158.
} 
way that anthropology operates through maintaining a conceptual framework of Africa as a whole differs from and is problematically grander than its localized condescension.

\section{Robin Derricourt's Inventing Africa: History, Archaeology and Ideas is}

concerned with the "limits and dangers of generalizing narratives about a complex continent," which in his examination is the way the written interpretations of historical findings have been complicit in concocting "generalized frameworks" about Africa that are neither accurate nor transferable. ${ }^{45}$ Echoing the preceding scholarship (much of which he cites), Derricourt describes "the range of "Africanism" as evolved over the centuries into two contemporary categories: "Negative images of a still-dependent Africa whose social and economic challenges require outside intervention and aid. Or they may be images of a continent with a romantic wilderness of landscape, flora, fauna and still-traditional societies."46 As he argues,

"We" need both terminology and description for "them"- - whether "them" is all of the African continent or those parts of the continent that are not us. This applies if "we" are the pharaonic Egyptians, or the Romans colonizing the Mediterranean coast, or the Islamic cultures distinguishing believer from nonbeliever. It applies if we are white South Africans looking north, or the modern American ecotourist or European charitable donor looking in from outside. ${ }^{47}$

Derricourt observes in particular the presence of "grand narratives applied to Africa,"48 which he seeks to clarify and analyze.

His first move is to deconstruct what primarily constitutes Africa, in the contemporary perspective. "Depending on context," he explains, "everyone draws a

\footnotetext{
${ }^{45}$ Derricourt, Inventing Africa, x.

${ }^{46}$ Ibid., vi-vii.

${ }^{47}$ Ibid., 149.

48 Ibid., X.
} 
different boundary around the Africa of their own choosing, ${ }^{, 49}$ in that the term Africa sometimes refers to black Africa, meaning sub-Saharan, or North Africa, meaning not black Africa. However, as critical race theory has explained, such approaches to geography work neither geographically nor genetically. If at first even a definitional argument of what constitutes Africa fails, then historical frameworks serve only to confuse matters more. While his analytical work begins by examining the conflicting notions of historical takes on Africa, Derricourt's definition of history is neither limited to a focus on the colonial period nor to one dating only as far back as contact with Europe. Instead, he illustrates that actual contact with Europe does not align with the typical understanding of the beginnings of the slavery era in the 1400s, but rather as far back as the classical era and ever since without interruption.

Derricourt's addition to this greater conversation therefore is to recite early in his text historical framings of Africa dating two thousand years in the past; in so doing, he argues for explorations of earlier rhetoric about Africa. While Derricourt is not the first to chronicle such references from ancient texts, he adds to the body of scholarship discussed here- which is to say those interested in conceptual constructions of Africaby suggesting that the way Africa has been invented or constructed can be traced back that far. He explains,

To the ancient classical world, the Islamic world, to a lesser extern medieval and early modern Europe, and importantly the colonizing European nation, it was important to have realistic knowledge of the part of the African continent with which they had contact; contact in trade, political relations or military encounter. Beyond that "real" world the imagination could develop without practical implication. ${ }^{50}$

\footnotetext{
${ }^{49}$ Ibid., 1.

${ }^{50}$ Ibid., 21.
} 
And so early in Derricourt's work, he chronicles the terms that have historically treated Africa. From "Punt" used by Ancient Egyptians to refer to black Africa probably to the southeast in Somalia or thereabouts - "a land neither to be feared (as another state) nor despised (as primitive nomads)" 51 _to the word Aethiopia, which referred to lands south of the Nile (Aithiops comes from aithes, "burnt," and opsis, "face") where in Homer's Iliad Zeus and other gods go off, as far away as possible, to banquet among the local residents, ${ }^{52}$ Derricourt presents evidence of these older Mediterranean and European conceptions of Africa.

Moving quickly beyond the examples of terminology, he further argues that concepts of Africa cannot be a relatively recent development due to the examples of historical contact. To that end, he begins by enumerating the many references to ancient naval trips by Greeks and their contemporaries to Senegal and Cameroon. He then moves through the many Muslim scripts doing the same, as early as the $8^{\text {th }}$-century traveler al-Fazari who "described the medieval kingdom called Ghana," the $11^{\text {th }}$-century geographer al-Bakri who wrote "of the people of Gao, Takrur, and Ghana," and the $14^{\text {th }}$ century traveler Ibn Battuta who famously went to "West Africa-noting the eastward flow of the Niger — and the East African coast."

And so Derricourt adds to the preceding scholars' insights the precursors to the medieval and early modern European conceptualizations of Africa. The argument that Africa was referred to as the Dark Continent in the late- $19^{\text {th }}$ century because so little was

\footnotetext{
${ }^{51}$ Ibid., 8.

${ }^{52}$ Ibid., 9-10.

53 Ibid., 13.
} 
known about it is therefore both factually and historically untrue. The question, as Derricourt clarifies, is precisely what was known about it. In reference to the Muslim sources, for example, he explains that Medieval "Europe's knowledge of Africa was thus not only limited but intermediated by Muslim perceptions and communications," point confirmed but also compounded and expanded by recent Medievalists' work. ${ }^{55}$

The arrival of the importance of a European point of view on Africa has to do with the arrival of the importance of Europe itself, something facilitated by its interaction with Africa but also conditioning the European characterizations of the continent and its representatives. Derricourt writes that when Africa was a major gold supplier for Europe, for example, there was no need to represent Africans as inferior; so they were received in European courts with civility: "Rank took precedence over race where required."56 However, the switch from gold to slaves forced the Europeans to "develop a concept of Africa and Africans in a different mould to mesh with the Christian conscience." ${ }^{, 57}$ As a result, while in renaissance Europe they had been grouped as blacks or as Africans, they were subsequently "reclassified by European societies as less than human; they lost

${ }^{54}$ Ibid.

55 See, for example, Robert Bartlett, "Medieval and Modern Concepts of Race and Ethnicity," Journal of Medieval and Early Modern Studies 31, no. 1 (2001): 39-56; Jefferey Cohen, "On Saracen Enjoyment: Some Fantasies of Race in Late Medieval France and England," Journal of Medieval and Early Modern Studies 31, no. 1 (2001): 113-146; Thomas Hahn, "The Difference the Middle Ages Makes: Color and Race Before the Modern World, Journal of Medieval and Early Modern Studies 31, no. 1 (2001): 1-37; or Kathleen Ann Kelly, "'Blue' Indians, Ethiopians, and Saracens in Middle English Narrative Texts," Parergon 11, no. 1 (1993): 35-52.

\footnotetext{
${ }^{56}$ Derricourt, Inventing Africa, 16.

${ }^{57}$ Ibid.
} 
individuality, history, culture and humanity in the ideology of the nations involved in the Atlantic slave trade over four centuries. ${ }^{.58}$

Having situated his audience in the overarching issues of these "grand narratives" of Africa, and in so doing theoretically justifying his approach and subsequent text, Derricourt shifts the focus of his work to the colonial period, critiquing the mythologizing work of the likes of H. Ryder Haggard and the Great Zimbabwe debates, the findings of early human fossil remains by Raymond Dart and the Leakey family, genetic evidence for human migrations in and out of Africa, Pharaonic theory in terms of cultural diffusion from or to ancient Egypt, and Basil Davidson's construction of histories of Africa. And so while alluding to a massive body of evidence for where inventing Africa began, Derricourt returns to the territory and time frame of the period since formalized colonialism.

Derricourt's introduction of ancient and medieval sources into this theoretical approach to Africa lays the groundwork for a detailed analysis and integration of those sources in future work; and his articulation of the rhetorical dilemma is relevant for use in contemporary analyses. Historical rhetoric about Africa is particularly poignant today because problematic rhetoric about Africa is undiminished:

Two longstanding images of the continent came to stand as contrasts in the perspective of outsiders to Africa. One could be described as romantic primitivism. The other attracted the new name "Afropessimism"; this saw social and economic decline leading to dependency, of numerous states and societies whose future success relies on external aid. ${ }^{59}$

\footnotetext{
${ }^{58}$ Ibid., 17.

${ }^{59}$ Ibid., 143.
} 
While the rhetoric of African dependency is familiar in the $21^{\text {st }}$ century, it is built upon that "romanticisation of aspects of the continent: Africa as a context for unspoilt landscapes, exotic wildlife, rural people leading simpler and more honest lives than their national urban compatriots or the developed world," and it is this "current enthusiasm for a timeless African wilderness, and for selected supposedly simpler societies within it, [that] provides a final aspect of the simplifying narratives of the continent."

While these works of scholarship seek to assess constructions and inventions of Africa in a broad sweep, several scholars have narrowed their contributions to the conversation to the beginnings of colonialism in the late- $19^{\text {th }}$ century. For example, Annie Coombes' Reinventing Africa: Museums, Material Culture and Popular Imagination in Late Victorian and Edwardian England follows the same line of critique as Appiah's in terms of revealing the way in which British rhetoric attempted to construct Africans in totalizing terminology. Her particular focus, however, rather than race or postcolonial literature is on the colonial library itself: she restricts her analysis to the texts surrounding museum collections, such as those on the bronzes and ivories taken from the Benin City royal compound during the Benin punitive expedition by British colonial forces in 1897 and other displays, such as the Earl's Court Exhibitions. Coombes assesses the various brochures and catalogues, for example, the way the depictions of Benin itself shift and morph based largely on proximity of the texts' authors to either first-hand experience or reported information, or the way exhibitors interchanged Senegalese actors for Sudanese characters in exhibition dramas. As a result, Coombes reveals a vivid picture of how Africa was conceived in the metropole during

${ }^{60}$ Ibid., 144, 149. 
this middle-colonial period, specifically how the less-well informed promotional materials for various exhibits spoke to preconceived notions of Africa by British citizens.

Coombes argues that the late Victorians accepted a belief that there was something rotten at the core of Africans, something degenerate, ill, and dark that must be isolated and dealt with. She writes,

The image of Africa, as it was presented to the British public in the last decade of Victoria's reign and the first decade of the twentieth century, has often been historically reconstructed as the product of a monolithic imperial propaganda. According to these accounts, Africa was uniformly reproduced through a series of tropes as a "land of darkness", "the white man's burden", peopled with savages of an inherently inferior order, both intellectually and morally, to the white colonizer. ${ }^{61}$

And so she follows in the same path of Appiah, both painting a picture of and rejecting the unanimism with which the subjects of her study were all too happy to depict Africa.

The nuance, however, that Coombes brings to the scholarly conversation is her observation that all British stakeholders in Africa shared this view of Africa, regardless of their politics. She writes of the "insidious appeal of colonial ideology, even amongst those philanthropic and humanitarian liberals who were its most ardent critics, ${ }^{, 62}$ revealing a collectively held set of concepts about Africa that were an accepted discourse. Coombes argues that the implications of this depiction are not for Africa, but, as Fanon suggests, for the colonizer who creates the discourse:

The Africa that existed in the popular imagination was an ideological space, at once savage, threatening, exotic and productive, inhabited by a population assigned a similarly disparate and ultimately contradictory range of racial traits. Representations of the African were, and are, evidently not "fixed" but eminently recuperable and variable, depending on the political exigencies of any specific historical conjuncture. As such, they necessarily tell us more about the

${ }^{61}$ Coombes, Reinventing Africa, 2. As will be discussed at length in the chapters on Sierra Leone and Liberia below, this is not as consistent or old of a rhetoric as suggested here.

${ }^{62}$ Coombes, Reinventing Africa, 2. 
nexus of European interests in African affairs and about the colonizer, than they do about Africa and the African over this period. ${ }^{63}$

What Coombes suggests here is that regardless of one's nature as a commercial or humanitarian colonial, a shared conception of Africa as "savage, threatening, exotic and productive" reflexively altered the colonizing country itself. ${ }^{64}$

Coombes clarifies her effort: it is her "contribution to the work of excavating the imperial and colonial consciousness, through an archaeology of certain institutions of colonialism. As such, [she is] primarily concerned with British perceptions of Africa and African culture." ${ }^{65}$ Coombes argues for an unbroken movement of this kind of analysis between the colonial and imperial eras, suggesting that colonialism is no more appropriate for such work than its precursors and is in fact on precisely the same continuum. She further argues that this work is first and foremost about unpacking British perceptions, which "tell us more about the speaking subject than they do about the African" $" 66$ and, as Appiah suggests, generally rely on a willingness to totalize Africans into a single, universal identity.

When Coombes identifies characterizations of Benin society in the late-1890s as having descended from a once-great ancient foreign race, ${ }^{67}$ she successfully aligns the colonial project in Benin with contemporaries making the same arguments, such as $\mathrm{H}$. Rider Haggard's arguments about an ancient Phoenician origin for the Great Zimbabwe

\footnotetext{
${ }^{63}$ Ibid., 3.

${ }^{64}$ A problem taken up quite recently by Robbie McLaughlan in Re-imagining the 'Dark Continent' in fin de siécle Literature.

${ }^{65}$ Coombes, Reinventing Africa, 5.

${ }^{66}$ Ibid., 22.

${ }^{67}$ Ibid., 11, 43.
} 
ruins in southern Africa. While Coombes' analysis, like Desai's, positions these British conceptions as "emerging definitions of race and culture,"68 this dissertation seeks through analysis of earlier primary materials to reveal that emergence at least several decades prior to her late- $19^{\text {th }}$-century focus, in order to unpack what she describes as "a set of obsessively repeated characters which were made to stand in for the multiplicity of cultures comprising the African continent." 69

Focusing even more narrowly than Coombes, Patrick Brantlinger in his "Victorians and Africans: The Genealogy of the Myth of the Dark Continent" sets out to resolve the seeming contradiction between the benevolent attitudes of Anti-Slavery-era Britain towards Africans and the malevolent ones by the beginnings of colonialism only decades later. Specifically, he explores how those British so vehemently against the institution of slavery in the early- $19^{\text {th }}$ century could turn to blaming slavery on the Africans themselves and re-characterize them not as inferior humans in need of paternalistic protection, but rather as vicious savages in need of domination. Making use of Foucault's framework of discourse and power and Said's Orientalism, Brantlinger considers this specifically British discourse as created through $18^{\text {th }}-$ and $19^{\text {th }}$-century poetry, visuals and plates from British colonial and expeditionary travelogues and novels, abolitionist texts, Darwinist works, and early anthropology, concluding that Africans were subjugated by the British because the British controlled the discourse and the Africans answered it with silence.

\footnotetext{
${ }^{68}$ Ibid., 43.

${ }^{69}$ Ibid., 63.
} 
His genealogical approach to the characterization of Africa reveals that at the turn of the $19^{\text {th }}$ century, Africa was characterized by the British (particularly by the Romantic poets) as a nearly Edenic place populated by simple and fragile beings in need of protection. Such a characterization served the abolitionist side of the slavery debate in England, leading to the British outlawing of importing slaves by 1807 . The British rhetoric then shifted from characterizing Africans specifically to a broader focus on the evils of slavery for Africa as a whole, and the European responsibility for that evil, which in turn supported the effort to end British slavery altogether in 1833. "The first abolitionists," writes Brantlinger, "had placed blame for the slave trade mainly on Europeans, but, by mid-century, that blame had largely been displaced onto Africans. ${ }^{, 70}$ And so those with an economic incentive to do so - the control of the continent's natural resources - and with Darwinian science in their service ventured into Africa. Writing of their expeditions and encounters, they depicted Africans as violent, cannibalistic, degenerate savages and Africa as a place of dissolute darkness, thereby justifying their immediate efforts as well as colonialism writ large. African response to such characterizations, Brantlinger argues, was neither gathered nor publicized, which allowed the British to believe a that Africans were merely silent because they were unable to enter into discourse. The notion (and specifically the linguistic modifier) of the "darkness" of Africa, Brantlinger argues, was therefore created through the rhetoric of these $19^{\text {th }}$ century British writings.

Lisa Jarosz's "Constructing the Dark Continent: Metaphor as Geographic Representation of Africa" builds upon Brantlinger's argument, accepting his explanation for the Dark Continent metaphor and briefly examining its origins further through the use

${ }^{70}$ Brantlinger, "Victorians and Africans," 198. 
of Dorothy Hammond and Alta Jablow's survey, The Africa that Never Was: Four Centuries of British Writing about Africa. Jarosz, however, is most interested in the use of the Dark Continent metaphor since its inception and proliferation, and she suggests two contemporary case studies - the Kariba Dam project and the AIDS epidemic — as a means of doing so. Seeking to "reveal the historical persistence and the ideological power of the metaphor" itself, she argues that today it "identifies and incorporates an entire continent as Other in a way that reaffirms Western dominance and reveals hostile and racist valuations of Africa and Africans. ${ }^{, 71}$ Jarosz reveals that the rhetoric surrounding the construction of the damn as well as western donations to the fight against AIDS are couched in the same ideology of the BBC Africa television program-that of bringing Africa what is needed from those outsiders who have it, be it loans, medicines, or understanding.

In this scholarly conversation, several gaps remain. As Jarosz, Brantlinger, and Coombes reveal, most of the scholarly analyses have focused on British constructions and inventions of Africa, to the exclusion of American involvement in that rhetorical work (from the slavery debates and creation of Liberia to evolutionary scientific contributions or the influence on Henry Stanley during his early adulthood in the U.S.). As a result, findings that should be limited in their representation to the late- $19^{\text {th }}$ century are often implied to represent the entire century or Victorian era, obscuring what specific constructions might have preceded and evolved into what, for example, Coombes, Brantlinger, and Jarosz have established. An additional factor is the greater ease of expanding our knowledge of the primary source material today, a technological shift that

\footnotetext{
${ }^{71}$ Jarosz, "Constructing the Dark Continent: Metaphor as Geographic Representation of Africa," 105; Jarosz's work is discussed in greater detail below in the context of Henry Stanley and the Dark Continent rhetoric itself.
} 
has made Hammond and Jablow's oft-cited work outdated due to its incomplete survey of British writing on Africa. Their text's exclusive survey of British writing also leads subsequent scholars to ignore the intrinsic relationship between British and American writers, particularly in the early-19 $9^{\text {th }}$ century when the countries had so recently been united politically and ideologically. Lastly, there is a need for a methodological consistency—a unifying approach—with the sorts of texts to be used to discover historical inventions and constructions of Africa and Africans.

The intervention of this dissertation, therefore, is to trace the specific historical evolution of the rhetoric of Africa and Africans in English since the beginnings of Abolition, uncovering the two rhetorical turns since that period that have heretofore not been discussed or analyzed, and in the process create an accurate picture of the source and meaning of contemporary rhetorics of a dark Africa. Furthermore, this intervention incorporates American rhetorics as part of the conversation, arguing for an Atlantic sensibility of rhetorics of Africa, in the vein of Paul Gilroy's Black Atlantic theories of continuity. And this intervention involves specific, thorough interrogations of primary sources, most of which have not been assessed for their rhetoric of Africa but all of which were central texts at the time of their creation and circulation. Lastly, this project seeks to intervene in the conversation by arguing for the sorts of texts that should be assessed in terms of the rhetoric of Africa.

When British and American interests in Africa shifted from slavery to colonization starting in the 1780 s, explorers were sent to the continent to travel inland, beyond its coasts. ${ }^{72}$ With the charge of seeking out viable settlement sites for penal

\footnotetext{
${ }^{72}$ Coasts with which Europeans and Americans were already quite familiar due to the centuriesold slave trade.
} 
colonies, resettlement colonies for freed Africans, or expanded geographic knowledge for trade purposes, it was these explorers whose task it was to report back their first impressions to their British and American employers. In these moments, Africa was constructed by the explorers and invented for those at home who subsequently encountered, assimilated, and responded to their texts. Focusing on explorers' accounts and the writings that came out of them as the starting place for analysis of the rhetoric of Africa provides a consistent framework, drawing that analysis to the source of the rhetoric, the pages of travel journals that eventually lead to homeland impression, constructions, and elaborations on Africa and Africans. Therefore, the final intervention of this project is to argue for the starting place in analyzing rhetoric of Africa in the texts of those British and American travelers who first went there to discover it anew, to know Africa as a territory rather than a border.

Chapter I of this dissertation explores the beginnings of Abolition in Britain after the 1772 Somerset Decision, in which slavery was outlawed on British home soil. Chronicling the factors that lead to the creation of the Sierra Leone colony for resettling freed British blacks, the chapter assesses the rhetoric of early explorer of West Africa Henry Smeathman, Sierra Leone Company corporate documents, and the reactions to them both in The Times. This chapter creates a comparison point for the later chapters through establishing what the rhetorical standard was for representing Africans and Africa at the time of Sierra Leone's creation. Because the rhetoric is varied, at times contradicting, and lacking a uniform vision of the continent or its people other than a general trend of focusing on the viability of Africa as a site for British post-slavery 
endeavor and a vague view of African cultural inferiority, the chapter seeks to clarify how the rhetoric of Sierra Leone serves as a counterpoint to the starkly different rhetoric that soon follows it.

Chapter II explores the creation of Liberia, the American colonial endeavor based directly on the British model of Sierra Leone. Revealing the specific rhetorics of Africa as benighted, fallen, and degraded, this chapter demonstrates the rhetorical turn that occurred between Sierra Leone and Liberia, when the importance of Christian faith trumped all other concerns for evaluating and characterizing Africa. Together, these first two chapters establish the setting for rhetorical imperialism; for however the rhetoric in the Sierra Leone period might seem compared to the subsequent Liberian-era rhetoric, both chapters reveal the way in which Britain and the U.S. maintained rhetorical sovereignty over Africa.

Chapter III includes two case studies that examine the extent to which such rhetorical imperialism can be contested. Through analysis of the travel journals of Samuel Crowther, the Nigerian recaptive settled in Sierra Leone who then returned to Nigeria years later as an explorer, and Martin Delany, the free African American who traveled to Nigeria to seek a settlement site that could challenge the white-controlled Liberia colony, the question Scott Lyons proposes of rhetorical sovereignty is considered. Crowther's and Delany's repetitions of the British and American rhetorics of Africa and Africans are assessed, as are their challenges to them.

Chapter IV reveals the path from the darkened Africa of the Liberian-era rhetorics to the Dark Continent rhetorics of the late- $19^{\text {th }}$ century. Exploring the rhetorical turn after the Liberian-era rhetorics, this chapter juxtaposes the rhetorical work of Henry 
Stanley and his reports of explorations in Central Africa with the simultaneous rhetoric of the Great Zimbabwe debates nearby. In so doing, the arc of rhetorical development since the Sierra Leone era is traced, complicating contemporary topical definitions of "Dark Continent" through that explicitly detailed heritage, and suggesting instead that its underlying meaning based on a more rhetorical etymology continues to limit opportunities for African rhetorical sovereignty today. 


\section{CHAPTER I: THE DISCOVERY OF SIERRA LEONE: BRITAIN GOES EXPLORING IN WEST AFRICA}

The classical consensus...is that these peoples in the hidden interior and on the farthest shores of Africa not only lack civilization but any worthy ethic of social organization or conduct as well. Anarchic, promiscuous, and cruel, they live the life of beasts rather than that of men. The most remote, in addition, are often denied the possession of a truly human form.

$$
\text { -Katherine George }{ }^{73}
$$

Disparaging rhetoric of Africans and Africa is certainly present in today's world: all one need do is watch the trailer for the movie Blood Diamond on YouTube, in which the movie is promoted by images of Africans who only scream, shoot, or do both while white people speak and engage romantically. ${ }^{74}$ Or consider another recent popular film, 2012, in which after a global flood has annihilated the planet, the survivors on a fleet of modern-day arks, discovering that Africa was never submerged, head there to restart humanity: for Africa is both dry land and empty. Ongoing scholarly work seeks to examine representations of Africa, Africans, and the racial Other between the classical period Katherine George describes and the modern era of such films as these. ${ }^{75}$ The

${ }^{73}$ George. "The Civilized West Looks at Primitive Africa," 64.

${ }^{74}$ See most recently, for example, Chrisman's "The Sight, Sound, and Global Traffic of Blackness in Blood Diamond." African Studies Review 55, no. 3 (2012): 123-144. Chrisman "explores the representation of Africa" through the film set in Sierra Leone, a contemporary example of Sierra Leone serving as a proxy for Africa both physically and rhetorically.

${ }^{75}$ Of particular note is the special issue of the Journal of Medieval and Early Modern Studies (31, no. 1, 2001) which focuses entirely on issues of race in the medieval era. The greater body of post-colonial scholarship examining constructions of Africa in the colonial era is vast, represented in the works of Mudimbe, Appiah, Ngugi, Fanon, Césaire, and Desai, among countless others. 
period of the British exploration and discovery of West Africa that led to the creation of the Sierra Leone Colony in the late- $18^{\text {th }}$ century, however, represents at least one break in such expressly negative characterizations of Africans and Africa. The Colony, an invention of British abolitionists seeking a permanent settlement site for the London Black Poor ${ }^{76}$ was established by 1792 after several attempts to secure livable land and a critical mass of people. While the reports coming from those who first explored and settled the area around the Sierra Leone River and the discussions of those reports in Parliament and the press in London reveal that the British maintained a generally condescending attitude towards Africans during this period, they nonetheless did not include the kinds of characterizations George describes or wild misrepresentations of American popular cinema.

Philip Curtin has written that "compared with their opponents—or with most nineteenth-century advocates of African colonization - the eighteenth-century projectors were remarkably free of overt racism, ${ }^{, 77}$ and we see this with the documents of the founding of Sierra Leone. These writings reveal that in the effort to create what would become Britain's first colony in Africa, British explorers set off for the shores of West Africa in the 1770s and 1780s on intentional journeys of discovery, explorations bent on gathering the sort of experiences and information that would inform reconsideration of the continent as a place for settling people rather than removing and enslaving them. Such exploring and documenting of Africa—different from writings by slave traders whose interests were arguably counter to the abolitionists'-provides a rich opportunity

\footnotetext{
${ }^{76}$ See below for discussion of the Black Poor.

${ }^{77}$ Curtin. The Image of Africa, 16. Also, however, see Chapter II on Liberia below, which challenges Curtain's claim that most $19^{\text {th }}$-century colonization proponents were overtly racist.
} 
for analysis. Embedded within their reports are informative rhetorical constructions of Africa and Africans, revealing attitudes at the turn of the $18^{\text {th }}$ century that were not clearly negative but instead often explicitly positive or empathetic. When discussing Africa, these writings about Sierra Leone have rhetorics that are self-contradictory, inconsistent, self-serving, complimentary, condescending, and ultimately varied; they are not uniformly negative, dehumanizing, or belittling of African civilization. The closest thing to a consistent trend shared among them might be that they constantly frame Africa according to questions of its viability and productivity, from an economically speculative lens, while interestingly not doing the same with Africans. ${ }^{78}$

This is difficult to establish as one rhetoric: the lack of consistent terminology and the equally inconsistent attitudes, even from the same writer, make it difficult to speak of the rhetoric of Sierra Leone. Rather, the great finding in analyzing the way Africans and Africa are depicted here is that there are a variety of rhetorics employed, none of which appear to reach clear dominance.

To arrive at the above conclusions, texts central to the founding of Sierra Leoneexplorers' reports and the discussions, debates, and promotions of their findings back home in Britain — are the focus of analysis here. This is carried out through examination of three kinds of essential texts chronicling the founding of Sierra Leone: the explorer's report, coverage in the popular press, and Sierra Leone Company promotional materials, each of which provide a different view of the development of the colony, and each of which repeat the same rhetorical approaches to Africa and Africans outlined above. The methodology employed in this analysis to reveal these findings is to isolate the places in

\footnotetext{
${ }^{78}$ Interesting because economic considerations of viability and productivity of Africans must have been on the mind of those active in the slave trade.
} 
these texts where references are made to Africa (either part or whole) or Africans (specified or generalized) and to assess those references for consistencies in descriptive language, content, and attitude in order to reveal the rhetorical intent of those representations. $^{79}$ Through the process of this analysis, it becomes apparent that the lack of a dominant rhetoric is, ironically, pervasive throughout the era of the founding of the colony.

Section I of the chapter assesses Henry Smeathman's initial report that proposed the settlement of Sierra Leone and some of the Black Poor Committee's discussions in reaction to his document. Section II explores the coverage in The Times of Parliamentary debate and the passing of the Sierra Leone Bill granting a royal charter to the Sierra Leone Company. Section III analyzes the corporate prospectus of the Sierra Leone Company, published to market its settlement scheme. And lastly, Section IV, returns to The Times for the second, tumultuous, but successful wave of settlement inspired by investors' response to the Company’s promotions.

I. Henry Smeathman, the Committee for the Black Poor, and a Plan for Sierra Leone The early editors of the 1817 iteration $^{80}$ of the colony's paper, The Royal Gazette and Sierra Leone Advertiser, inscribed its masthead with "Virescit, Vulnere, Virtus," loosely translated as virtue ripens through wounds. ${ }^{81}$ That Sierra Leone is a place where

${ }^{79}$ The same methodology used throughout this dissertation.

${ }^{80}$ Christopher Fyfe chronicles the various incarnations of Sierra Leone newspapers from the start of the Sierra Leone Gazette in 1801 through The Royal Gazette and Sierra Leone Advertiser, first printed on August 2, 1817, and beyond (see Fyfe, "Introduction to the Microfilm of the Sierra Leone Gazettes," in "The Royal Gazette - Sierra Leone 1808-1810 / 1817-1827," 1).

81 "The Royal Gazette - Sierra Leone 1808-1810 / 1817-1827.” 
good will be achieved through suffering serves as a poignant preface for how the rhetoric of Africa arose through this late- $18^{\text {th }}$-century nexus of British exploration. As Philip Curtin writes,

Since West Africa was the core-area of the old slave trade, it was the first part of Africa to attract attention; and the British image of "the African," and of African conditions generally, was initially concerned almost entirely with West Africa....for Britain itself, the early-nineteenth-century image of Africa was, in fact, the image of West Africa. ${ }^{82}$

Of all the possible sites for British focus on the West African coast, however, the peninsula and naturally protected harbor on the Sierra Leone River estuary arguably became central as much by chance as any other factor.

The failure of Britain in the war with its American colonies led to groups of exslaves who, having fled slavery to fight on the losing side of the British, made their way to London or were evacuated to Nova Scotia. ${ }^{83}$ By the late-1780s, certain wealthy Londoner humanitarians, including Granville Sharp, had taken notice of them on the streets of London and formed the Committee for the Relief of the Black Poor. ${ }^{84}$ At first the Committee sought to feed and support those benefiting from the Somerset Ruling of 1772 that outlawed repatriating freed blacks to slave territories, ${ }^{85}$ but soon its resources were exhausted and members sought government support and alternatives, such as

\footnotetext{
${ }^{82}$ Curtin, An Image of Africa, vi.

${ }^{83}$ This has been explored extensively by Fyfe in A History of Sierra Leone and Sierra Leone Inheritance, Wilson in The Loyal Blacks, Braidwood in Black Poor and White Philanthropists, as well as by Kup, Mouser, Schama, and most recently by Land and Schocket and Sharpe.

${ }^{84}$ Kup, "John Clarkson and the Sierra Leone Company." 203.

${ }^{85}$ Ibid. Kup writes, “After Lord Mansfield's celebrated judgment in the case of James Somerset in 1772, which declared that it was illegal for a master to forcibly remove his slave from England to sell him in the New World, all were free."
} 
resettlement. ${ }^{86}$ At the same time, the scientific community's interest in botanic and geographic knowledge had led luminaries such as Joseph Banks, ${ }^{87}$ to dispatch explorers in pursuit of further knowledge, as well as specimens for study or cultivation. Banks employed Henry Smeathman to travel to West Africa in 1771, who during a residency of nearly four years became an expert on termites and gained broad knowledge of what was referred to as the Grain Coast. ${ }^{88}$

Smeathman's biographer Griffin writes that "his visit to Africa was primarily to collect specimens, but he corresponded with Linnaeus and sent him undescribed plants." "89 Furthermore, he "left England to collect for his 'Subscribers' Dru Drury, John Fothergill, Marmaduke Tunstall, Joseph Banks, and, later, the Dowager Duchess of Portland." 90 As Griffin reveals, Smeathman planned to trade in a profitable export of specimens for these collectors. Delivery of his specimens however was small and intermittent to their chagrin, and his final collection, while massive was nonetheless too little too late and led to significant financial problems for him, the solution of which was “another scheme, for forming a settlement of Poor Blacks near Sierra Leone, in which he

${ }^{86}$ Ibid.

${ }^{87}$ Founding botanist at Kew and future President of the Royal Society, the scientific society chartered by Charles II at the beginning of the Restoration; Banks was President from 1778-1820 (http://royalsociety.org).

88 Schama, Rough Crossings, 219; also Curtin, who writes, "Two general ways existed for organizing the flow of data from overseas for scholarly ends. One method, in occasional use for centuries, was to send a questionnaire to people who were already there.... The second alternative was to send junior researchers with specific objects in mind....Sir Joseph Banks followed the same method" (The Image of Africa, 14-15).

${ }^{89}$ Griffin, "Henry Smeathman,” 1.

${ }^{90}$ Ibid., 2. 
was supported by Jonas Hanway, Samuel Hoare and others, with a promise of assistance from the Commissioners of the Treasury." $" 91$

And so when the Committee for the Relief of the Black Poor ran short of the resources necessary to accomplish its mission in London and began to consider resettlement of the Black Poor elsewhere, Smeathman leveraged his West African experience into a proposal to the Committee, as Curtin writes, "To become the first promoter of the English settlement at Sierra Leone." 92 While some in Parliament had pushed for a West African site for a penal colony and had sought Smeathman's advice on the possibility, he rejected the plan on the high likelihood of prisoners and guard mortality. ${ }^{93}$ Instead in Plan of a Settlement to be made near Sierra Leona, on the Grain Coast of Africa (1786), he recommended that the part of West Africa with which he was particularly familiar — the Sierra Leonean peninsula — be used for a Black Poor resettlement scheme. Published for the Committee, Smeathman's text was later used as the blueprint for the original 1787 settlement, what Sharp would call the Province of Freedom.

A careful examination of precisely when and how in his Plan he refers to Africa or Africans suggests the state of thinking about the continent by those who were beginning to be there not for the purposes of the slave trade, but rather to know the place
${ }^{91}$ Ibid., 6, 9.
${ }^{92}$ Curtin, An Image of Africa, 16.
${ }^{93}$ Fyfe, A History of Sierra Leone, 15. See also www.blackloyalists.com/canadiandigitalcollection. This decision away from West Africa led to the formation of Botany Bay; see Coleman, "Sierra Leone, Slavery, and Sexual Politics,"4, where Coleman cites Wilson, The Loyal Blacks 141-2, and Curtin, The Image of Africa, 94-96. Coleman sees in the "ironic conjunction notions of transportation and of resettlement, the convict and the free." 
and its people, even if doing so was in the service of assessing the viability of a scheme to displace a London social problem. At the outset of the Plan, Smeathman refers to Sierra Leone first by depicting it in promotional terms, as might be expected given his hopes for the implementation of his design. He suggests that "any person desirous of a permanent and comfortable establishment, in a most pleasant fertile climate, near Sierra Leona, where land may be purchased at a small expence may have an opportunity of doing it on the following advantageous conditions." 94 Here, Africa is described as a land of opportunity where it will rise up to meet one's effort in kind. In a more detailed characterization of the environment at Sierra Leone itself, he writes that the

favourable circumstances, combined with the peaceable temper of the natives, promise the safest and most permanent establishment of commerce; the numerous advantages resulting from the quiet cultivation of the earth, and the exploration of its valuable productions, which may be exchanged to great advantage for the manufacturers of this country. ${ }^{95}$

Within this first description lie the three central claims Smeathman argues in favor of Sierra Leone throughout his treatise: that it is a fertile and peaceful environment, that the local people will not challenge the settlement, and that it will perfectly initiate a commercial market between Africa and Great Britain based on products rather than people.

When Smeathman specifically mentions Africa in his text, his precise language is unadorned: on the title page he situates Sierra Leona on the "Grain Coast of Africa," in distinction to the Gold Coast further east. ${ }^{96}$ Importantly the word Africa is only modified

\footnotetext{
${ }^{94}$ Smeathman, Plan of a Settlement, 3.

95 Ibid., 9.

96 The English names for regions of the coast refer to what products were most readily available for trade on that portion of coastline. The Gold Coast refers to the gold trade coming out of what is today southern Ghana, dating back to the first Europeans to arrive hundreds of years earlier. The Grain Coast
} 
by the specific part of the coastline to which Smeathman refers; it is not a modification with any adjective or, significantly, evaluative sensibility. The only other time he mentions Africa by name is midway when he refers to "the coast of Africa" or simply "the coast," $"$ " equally unadorned descriptions of the continent.

Smeathman's somewhat vaguer reference to Africa comes at the times when he uses the word "country" as a proxy for Sierra Leone. Several times he simply refers to it as "that Country," "this country," "the country," the simple use of demonstrative adjectives allocating no evaluation to Africa. ${ }^{98}$ Given that Smeathman's Plan was expressly a rhetorical document meant to sway the Committee for the Black Poor favorably towards an African settlement by which he might benefit, it is not surprising that the Plan was not overtly condescending or negative towards Africa. It might be expected, however, that at a time in which enslavement of Africans was at its height, some derision towards the people, even if subtle, would be found.

Quite to the contrary, not only are the word and phrase-level references to the continent ambivalent, but the more developed depictions are Edenic. Sierra Leone is where everything is readily at hand. Smeathman writes of a

climate not requiring either compact or durable houses: a slight hut is a sufficient shelter for the severest season of the year; and the material for building are so near at hand, that a company of ten or twelve men may erect very comfortable habitations for themselves and their families in a few days. Each person will be

refers to the prolific grain production of the region, the reputation of which lead to the exporting of communities from there to the Carolina and Georgia Lowcountry, to what is now known as the Gullah region, for rice production. That the regions in West Africa were referred to as "Coasts" at this time in British geography indicates again how Britain perceived Africa as a border rather than a territory prior to the explorations that lead to Sierra Leone (and eventually, some years later, South Africa).

${ }^{97}$ Smeathman, Plan of a Settlement, 11, 4, 8, 10.

${ }^{98}$ Ibid. 
allowed, by common consent, to possess as much land as it may be judged he or she can cultivate. ${ }^{99}$

This Africa is the land of milk and honey, a place of utter satisfaction and fulfillment. He expands this image, moving from housing to protein, explaining that settlers

will have other easy means of supplying themselves, not only with the necessaries, but also the conveniences and comforts of life. Such provisions as fowls, hogs, goats and sheep, are very cheap, being propagated with a rapidity unknown in these colder climates; and great quantities of fish may be caught with the utmost facility: the forests abound with venison, wild fowl, and other game. ${ }^{100}$

And so while Africa will provide materials, an easy-going environment, and enough land to satisfy the demands of one's hard work and aspiration, it is also a fecund place where one need not fear going hungry, unlike the streets of London. That productivity is not limited to domesticated animals and game, however, as the overall ability of Africa to generate lucrative natural resources as well as resource-based products is, according to Smeathman, intrinsic:

The productions of this country are Rice, and a species of Indigo superior to any other, Cotton and Tobacco equal to those produced in the Brasils, and purchased of the Portugeuse [sic], Dying Woods of various kinds, Ivory, Wax, Tortoise Shell, Gold, and other merchandise. Add to this, the woods and plains produce spontaneously great quantities of the most pleasant fruits and spices, from which may be made oils, marmalades, wines, perfumes, and other valuable articles, to supply the markets of Great-Britain and Ireland. ${ }^{101}$

Africa's potential is such that it suggests the production not just of sustenance but of surplus.

Smeathman's rhetoric is either ambivalent, casting Africa geographically through plain description, or decadent, when it comes to the particular part of Africa for which he
${ }^{99}$ Ibid., 6.
${ }^{100}$ Ibid., 7-8.
${ }^{101}$ Ibid., 8. 
advocates, and this sets a tone for those who will read and cite his work - that the rhetoric of Africa in the lens of colonization (a still future endeavor for the British in the 1780s) is either neutral or positive and opportunistic. The significance of the absence of negative depiction regarding Sierra Leone contrasts starkly with later periods where adjectives are repeatedly fixed to the word Africa and specific rhetorical negativity is cast upon the continent. That this is not the case with Sierra Leone predicts a rhetorical turn and importantly suggests that what rhetoric evolves out of Sierra Leone will maintain some of the ambivalence or positive sensibility about Africa portrayed by Smeathman and his contemporaries.

Smeathman's tone, begun by his list of what will be needed by each settler heading to Sierra Leone, is one of utmost pragmatism, making a case for simplicity—not that one should pursue simplicity, but rather that it is all that is needed to enjoy a comfortable and happy life there. In language reminiscent of Thoreau's sixty years later, Smeathman argues that at Sierra Leone,

Such are the mildness and fertility of the climate and country, that a man possessed of a change of cloathing, a wood axe, a hoe, and pocket knife, may soon place himself in an easy and comfortable situation. All the cloathing wanted is what decency requires; and it is not necessary to turn up the earth more, than from the depth of two or three inches, with a slight hoe, in order to cultivate any kind of grain. ${ }^{102}$

It is the place where everything a settler needs would be available, or anything he or she wants could be grown; and as a result, he suggests that "the climate is very healthy to those who live on the productions of the country."103 In response to some preceding concern regarding "why it has been fatal to many white people," and as a precursor to

\footnotetext{
102 Ibid., 8-9.

${ }^{103}$ Ibid., 10.
} 
encouraging settlers to envision a path where they would only be reliant on Committee support for "three months," he argues that it was because those slave traders settled near "close rivers or creeks, not choosing healthy spots" or that they did not know how to treat "diseases in that climate."104 In his final analysis of Africa itself, therefore, Smeathman's rhetoric constructs a land containing "one of the most pleasant and fertile countries in the known world."105 Smeathman's text was foundational in how it informed and was cited in discussions and debate of Sierra Leone; his rhetoric of Africa is essential to understanding where some of the greater British rhetoric was coming from in this period.

Similarly, his rhetoric of Africans portrays them as entirely suitable neighbors, both to Diaspora settlers and the British who would accompany them. He acknowledges that his positive characterization of Africans is, however, contradictory to what some of his contemporaries might expect, as he states, "The Africans in the neighbourhood of Sierra Leona, are sagacious and political, much beyond what is vulgarly imagined." 106 While Smeathman writes for an organization with several members of abolitionist leanings, he brings up contrary, vulgar imaginings of Africans seemingly with a nod to the greater society in which he writes, one thoroughly involved and invested in an active slave trade. That vulgar-or common-imagination suggested by Smeathman is the one holding a view of Africans as generally unwise and ignorant of politics, a derision

\footnotetext{
${ }^{104}$ Ibid., 10, 4, 11.

105 Ibid., 24.

${ }^{106}$ Smeathman, Plan of a Settlement, 10.
} 
commensurate with allowing them to continue to be enslaved in the service of British interests.

Smeathman himself, however, only refers to the people as either "Africans" or "natives," 107 and those words are themselves unmodified other than the example mentioned above. He does describe a system of finance and business already in place, referring to "the currency of the country" and the fact that "a lucrative trade may be carried on with the natives." ${ }^{108}$ Additionally, he hints at the presence of local social organization, specifically "the custom of the country," or that if settlers "[offend] against the natives, in neighbouring districts, they will be amenable to the laws of the country."109 Here the word country takes on the political specificity of a place of trade, currency, custom, law, and sensitivity, rather than the vague geographic definition and usage of the term.

However positive these representations of Africans and Africa may be, it is important to keep in mind that Smeathman also employed an ambivalent rhetoric of them. For example, while he describes Africa as Eden and the people as organized, he carves out a rhetorical landscape that is ideologically empty of Africans and their influence, a logistical necessity if "settlers" or "adventurers"110 are to immigrate there without displacing residents, but a fabrication because such emptiness was factually untrue. When Smeathman writes, for example, that the settlers "will also be entitled to the necessary allotment of a quantity of land, and other benefits, in as great a latitude as will

\footnotetext{
${ }^{107}$ Ibid., 10, 24, 15-16.

${ }^{108}$ Ibid., 13, 15.

${ }^{109}$ Ibid., 15-16.

${ }^{110}$ Ibid., 24, 18.
} 
render their lives easy," ${ }^{111}$ he argues that no one is in possession of the land or making use of it, promoting an image of an un-peopled landscape, or where the scattered inhabitants will not mind being moved to the side for settlers.

He further writes, "It is also intended that the adventurers shall be accompanied by a Clergyman, in order to promote Christian Knowledge; likewise a Schoolmaster and Mistress, that those who have children may have them instructed."112 Here Smeathman clarifies that they will need a priest and a teacher because neither are present there already. In the grand scheme of things, the land is perfect, the nature of area Edenic, but the society is absent, or at least inadequate. This latter depiction seems to challenges Smeathman's prior one of civilized Africans, and the nature of this disparity is that while he acknowledges some qualities in the Africans that are familiar and positive, their social organization is inadequate for British needs: fertile ground lacking the gardener. The Africans are simultaneously there and not there, civilized and heathen, grandly productive yet disconnected from the land which enables such surplus. This inconsistent rhetoric of Africans is an essential finding: they are not clearly delineated or occupying a fixed rhetorical space, other than that they will not cause problems for the development of Sierra Leone. Smeathman combines the fertility of Africa with Africans who are not impediments to construct a rhetoric of them as viable for British interests.

This rhetoric of viability recalls Smeathman's argument that settlement would initiate an ideal trade in goods between England and Africa. And so from the first moment in the era of Sierra Leone - that point when Britain first looked at the continent

\footnotetext{
${ }^{111}$ Ibid., 18.

${ }^{112}$ Ibid., 12.
} 
with probing eyes - the rhetorical construction of Africa has also inextricably to do with trade. Those African productions already mentioned — the foodstuffs, dyes, oils, construction materials—will, as stated above, "supply the markets of Great-Britain and Ireland," where they "will find a ready market, and receive the manufactures and other necessaries imported from Great Britain in exchange."113 Smeathman depicts a trade that involves Africans not as the product but as the partner: as Deirdre Coleman writes, "Instead of selling them, the idea was to sell them goods."114 Local African traders would themselves remain in their positions as merchants, but with a stock of a different sort altogether.

With this shift from the slave trade economics, however, Smeathman invokes the old lexicon, writing, "Such will be the situation of those adventurers who occupy themselves on their plantations" and "their own freehold plantations and gardens." 115 While the trade is not in people as such, it is a good reminder that the material with which Smeathman is encouraging the Committee for the Relief of the Black Poor to work is the Black Poor, this subjectivity arguably constructing the Black Poor as more of an it than a they. It is, as he writes, still the world of the plantation, a rhetorical space in and of itself meant to contain black people in the context of white hegemony. While not constructing Africans through an explicitly negative image, it does reveal an underlying assumption of British superiority over them, an integral if understated component of his rhetoric. What Smeathman's proposal suggests, in prepositional terms, is an Africa with which one does,

\footnotetext{
${ }^{113}$ Smeathman, Plan of a Settlement, 8, 14.

${ }^{114}$ Coleman, "Sierra Leone, Slavery, and Sexual Politics," 5.

${ }^{115}$ Smeathman, Plan of a Settlement, 13, 14.
} 
in addition to an Africa from which one takes. As Land and Schocket state, "The establishment of a settler colony with a territorial footprint in Africa marked a new departure"; it is, they explain, "what historians refer to as the first British Empire."116 Smeathman published and presented his report in early 1786 to the Black Poor Committee, which initially accepted it; however, his death shortly thereafter in July of that year ${ }^{117}$ called into question the decision to resettle the Black Poor in Africa, particularly by Committee chair Jonas Hanway, whose inclination was Nova Scotia where other Black Loyalists had attempted settlement. ${ }^{118}$ The Committee's meetings that summer consisted of deliberations between settlement locations, and their minutes reveal rhetoric similar to Smeathman's, including language at times seeming to invoke his treatise, an indication of the influence of his Plan on subsequent rhetorics of Africa and Africans.

These minutes construct Africa as a site of illness, something Smeathman worked to refute. They speak of "another great ambiguity respecting the Coast of Africa. The various accounts given leave many doubts. Mr. Smeathman himself brought from thence a Constitution which lasted him but a little while, and always seemed to be more anxious about his medical knowledge and Medicine Chest than his Tools for husbandry." 119 While the minutes are clear about referring only to the Coast of Africa- the site of their interest, but also the limit of their knowledge - they reveal a preceding rhetoric of Africa

\footnotetext{
${ }^{116}$ Land and Schocket, "New Approaches to the Founding of the Sierra Leone Colony," n.p.

${ }^{117}$ Fyfe, A History of Sierra Leone, 15; Griffin, "Henry Smeathman," 1.

${ }^{118}$ The Black Presence Exhibition.

${ }^{119}$ Ibid.
} 
as a place of illness, grounded in a suspicion due both to Smeathman's demise after having lived their for several years and his privileging of the medical.

Expanding on this, they continue, "To all appearance there will be much greater security for liberty and life and the Comforts arising from freedom and health in his Majesty's Dominions in New Brunswick than there can possibly be in any Part of the Coast of Africa." ${ }^{, 20}$ New Brunswick additionally was already Christian as well as governed, "The peaceful Government of which must be a security beyond any which the most sanguine hope can suggest respecting Africa." ${ }^{, 21}$ The Committee's fears for a settlement in Africa were not precisely a fear of Africa or a condescension towards Africa, but rather a wariness of the mire which it had become due to the European slave trade, as well as simple health issues which, while stated as unfavorable, are not equated in any kind of evaluative way suggesting something morally or culturally problematic about Africa. Indeed, the language of Africa in these initial minutes, like Smeathman's, is plain, invoking his more ambivalent rhetoric: it is "Africa," "the Country," "the whole Coast of Africa," "that Country," or "any Part of the Coast of Africa." Here too is Africa unadorned, in spite of the Committee's preference against Africa and for North America.

The significance of this cannot be understated. If the rhetoric of settlement is often about enticement, that is, if the Committee opposes Africa and wants New Brunswick, they might be inclined to emphasize a number of problematic aspects of Africa. That the contrary is true argues strongly against entrenched negativity about Africa at this time, and rather begins to paint a portrait of a pervasive rhetorical trend at
${ }^{120}$ Ibid.
${ }^{121}$ Ibid. 
the time of representing Africa and Africans ambivalently at worst, and enthusiastically when needed.

On 6 October 1786, a "Memorandum of Agreement" was drawn up between the would-be settlers and the British government, outlining the legal commitment of the settlers to go to Sierra Leone and the assurance of the Crown—now represented by Joseph Irwin after Smeathman's demise — that they would be protected from slavery upon arriving in Africa. Specifically, the agreement states that the signing Black Poor "choose and wish to be happily Settled on the said Grain Coast of Africa" and that the British government "will provide for all and every of the undersigned Men Women and Children proper Certificates of their being Loyal Subjects to His said Majesty King George the Third his Heirs and successors to be printed on Parchment and deliver them in a Tin Box in order to preserve the same." 122

The government's rhetorical construction of Africa and Africans bears a striking similarity to the documents created by Smeathman and the Committee: while there is no mention of Africans, the "Grain Coast of Africa" phrase is repeated four times, the only reference to Africa itself. The rhetoric that Smeathman used for depicting Africa and Africans was carried forward by subsequent parties in the first stages of development of Sierra Leone, with its generally ambivalent tone and content; little would change as the Sierra Leone Colony progressed from idea to implementation.

By 16 February 1787 , nearly 400 black men and women, white women, ${ }^{123}$ and their children were on board the Vernon, the Atlantic, and the Belisarius and waiting to

\footnotetext{
${ }^{122}$ The Black Presence Exhibition. "Bound for Sierra Leone.” T 1/638, no. 249 (6 Oct 1786).

${ }^{123}$ Much has been made of who was put on board the boats that undertook the first wave of settlement of Sierra Leone. Until recently, historians referred to the "women of the lowest sort" who had
} 
leave British waters for Sierra Leone. ${ }^{124}$ On 9 April of that year they sailed, but by

1791 - due to death on the journey, illness upon arrival, and getting caught in the politics

between slave traders and locals once there-only 60 of them survived. ${ }^{125}$ Nonetheless,

Smeathman's Plan and its rhetoric of a viable Africa and inoffensive or irrelevant

Africans successfully paved the way for the first attempt at establishing a British Colony

on the coast of West Africa.

II. In the Eye of the Public: the Establishment of Sierra Leone and The Times

The Times, which came into existence in London at approximately the same time

Sierra Leone transitioned from slave factory to colony, ${ }^{126}$ tracked Sierra Leone's

inception and early history. Providing a glimpse into the discussion and debate at the

national level of the colony scheme and its implementation, The Times reveals a more

public view of and reaction to the efforts Smeathman and the Black Poor Committee

been forcibly placed on the settlement ships under false pretences and then forcibly married to the Black Poor men. The massive mortality prior to arrival in Africa of this first wave of settlers has historically been attributed to what these settlers supposedly brought with them - the loose morals and disease of white prostitutes and the lack of restraint and inebriation of the Black Poor men. At least one specific source of this explanation is Anna Maria Falconbridge, although she too may be citing an earlier source. Braidwood as well as the National Archive Black Presence Exhibition have recently corrected this history, through the manifests of passengers as well as the record of the ships' journey. The white women who joined the settlers were already the wives of the Black Poor men, and these couples brought their children with them on the journey: in short, the first wave of settlers consisted of whole families who sought another life in Africa. The inefficiency of the Committee's plans for the journey to Africa, however, meant that the boats once underway were forced to stop down river on the Thames for several months with the settlers living on board under atrocious conditions, leading to the wave of illness that wiped out much of their population prior to departing from England.

${ }^{124}$ The Black Presence Exhibition. "The Passenger Lists of the Vernon and the Atlantic." T 1/643: 135-38 (Feb 1787).

${ }^{125}$ The Black Presence Exhibition.

126 From 1785-1788 the Times was known as The Daily Universal Register. From its inception, it reported on topics including legal proceedings, Parliamentary debate, gossip about royals, real estate and financial transactions, reports from the Continent as well as British colonial affairs, and news of social welfare and philanthropic endeavors. That the paper faced little competition lead to a substantial readership in London and further afield. 
undertook and the rhetoric Smeathman propagated. Over the decades, the primary and most prolific news source in Great Britain reported the parliamentary debates in the early 1790s and the ongoing fiscal reports and challenges of the Sierra Leone Company, the eventual failure of Sierra Leone as an economic prospect but success in securing the passage of abolition, and the 1807 return of the territory to the crown and its beginnings as a colony.

The first years from The Times on Sierra Leone trace a dual path of abolitionist interests related to the effort to end slavery and the exploratory interests in the continent of Africa, which are tied up in similar aspects of coming to terms with Africa as the African Association that subsequently employed Mungo Park: geography and both import and export commercial interests are paramount. Woven into the ongoing narrative The Times reports, however, is rhetoric of Africa and Africans, the careful analysis of which reveals a continuity with that of Smeathman and the Black Poor Committee: the people and place are again constructed rhetorically with either ambivalence or promotion of the viability of the place, and depictions of the people that are condescending but devoid of consistent terminology of belittlement.

The first appearance of Sierra Leone in The Times regards the parliamentary debate over the Sierra Leone Bill, when the St. George's Bay Company sought a Royal Charter. ${ }^{127}$ The debate is not only a glimpse into depictions of Africa that are parallel to Smeathman's, but also the revelation that those ways are pervasive between the

\footnotetext{
${ }^{127}$ The St. Georges Bay Company was the precursor to the Sierra Leone Company and formed by members of the Clapham Sect, most influential of whom were Granville Sharp, Henry Thornton, Thomas Clarkson, and William Wilberforce. See Mouser, "Trade, Coasters, and Conflict in the Rio Pongo," 55; Kup, "John Clarkson and the Sierra Leone Company," 203; and Curtin, An Image of Africa, 97-98.
} 
competing sides: those with slave trade interests speak of the continent no differently from those with abolitionist sentiments. The discussion of the bill, reported on 4 May 1791, begins with "a petition from the Merchants trading to the Coast of Africa, praying that the Bill for establishing the St. George's Bay Company on the River Sierra Leone, might not pass into law." This association of merchants descended from the Royal African Company, the first chartered monopoly of British slave traders; somewhat ironically, their "principal objection to this Bill went on the ground that it would establish a monopoly, and thereby injure the Slave Trade." ${ }^{128}$ Liverpool MP Bamber Gascoigne, who appears throughout The Times over the first three decades of British Sierra Leone as chief Parliamentary detractor, elaborates the pro-slavery block's objection: in "that quarter of Africa, the River Sierra Leona was the only river for conveying the produce of the country for a length of coast extending 1600 miles. If therefore it was meant in the smallest degree by this Bill to restrain the African Slave Trade in that quarter, or in any respect to create a monopoly, he should oppose it." Interesting in even these first statements in The Times about Sierra Leone — and those by investors in the slave tradeis the simple, geographical way Africa is described, in keeping with Smeathman's method in his Plan.

This consistency continues. While the Sierra Leone Company's own documents speak of its purpose to bring an end to slavery, ${ }^{129}$ the 4 May 1791 report of the Parliamentary debates in The Times quotes Thornton denying this: "The object of the bill was simply," he states, "to erect into a company certain persons, in number about an

\footnotetext{
${ }^{128}$ Fyfe, A History of Sierra Leone, 7, 4-5.

${ }^{129}$ See the October 1791 Substance of Report of the Court of Directors, in which it states that "they will not deal in slaves themselves, nor allow of any slave trade on their ground" (51).
} 
hundred, who wished, partly from public spirit, and partly from speculation, to attempt a more extensive trade with Africa in the natural productions of that country. He could not possibly see how the Bill could affect the Slave Trade in the smallest degree." Even when Gascoigne expresses the Merchants' incredulity at "what was really the object of the Bill," Thornton maintains it is "having a quiet territory in which the company could carry on the trade without any danger. With regard to preventing the Slave Trade from being carried on in that quarter, it was perfectly groundless; the bill only gave the land on one side of the River Sierra Leona; and this river was just as applicable as it was before to all the purposes of the Slave Trade." Africa and its geographic features continue to be described plainly and factually.

This is not to say that the debate is free of bias, any more than Smeathman's Plan is. The "clause in the bill that...gave the company the privilege...of purchasing...thirty miles in length on the side of Sierra Leona"130 echoes Smeathman's claims about the ease of land acquisition; both reveal that general assumption of Britain's superiority and belief in its ability to get what it wants. While the reported debate in Parliament was a collision of two competing sets of British interests — slavers versus abolitionistsconsideration of the field of battle was irrelevant. ${ }^{131}$ And the ability of this debate (and the general conversation of this time) to disregard local considerations is suggestive not of an ignorance or dismissal of the challenging logistics or local resistance, but of a general disregard of the presence of Africans or the landscape of Africa as a noteworthy

${ }^{130}$ The Times, 4 May 1791, 2, B.

${ }^{131}$ Arguably, in fact, what was being implicitly debated was precisely where the field of battle would be, which is to say, whether or not it would be outsourced to African soil. This was not an insignificant consideration, given that the choice to keep the contest between pro-slavery forces and those of abolition on home ground was one chief difference between the American internal slavery dispute and the British one. 
long-term challenge to settlement. Such condescension arguably comes from an attempt again to position the area in Africa as a viable one for British colonial goals.

Coverage in The Times of the Sierra Leone Bill debates continued through May of 1791, with the Merchants in the West Indies and the Merchants of Liverpool, sibling slaving organizations, joining the African Merchants in their continued objection to the bill. ${ }^{132}$ The depiction of Africa without rhetorical embellishment continued as well: on 17 May 1791, when Lord Sheffield requests that all land distributions already made at Sierra Leone be published for Parliament's examination, he refers to "the peninsula of Sierra Leone, on the coast of Africa." Africa here is simply Africa, a geographical marker: the way local Africans might respond to British settlement is not part of the debate, ${ }^{133}$ and neither is any explicitly slanted depiction of the peninsula. ${ }^{134}$

On May $31^{\text {st }}$, The Times covers the final stages of the debate of the Sierra Leone Bill, in which British sense of superiority of Africans is perhaps displayed most clearly in all of the rhetoric of the founding of Sierra Leone. Speaking against it, Mr. Cawthorne "was hostile to the principle of the Bill as well as to all its component parts":

He ridiculed in pointed terms the assignment that had been made by the Prince of the district—King Tom — of the lands to his Majesty—-he moved that the deed

${ }^{132}$ The Times, 13 and 24 May 1791, respectively. I use the term coverage in regards to The Times writings about Sierra Leone at this point (1791) because the newspaper had yet to form news reporting into distinct articles or even sections. The reporting on Sierra Leone often came in unbroken prose with social reporting, legal announcements, etc. By 1795, headings appeared on a more regular basis.

${ }^{133}$ Perhaps because it was thought in London that no one in fact inhabited the proposed site, a belief that plausibly eased goals of settling large numbers there - there was, in short, no one to displace, a notion supported by subsequent descriptions in Substance of the Report of when the first wave of settlers "took possession of some deserted houses that were standing" (7). Later reports in the settlement of the colony indicate that this neighborhood had become empty due to its inhabitants having been taken into slavery en masse. thereafter.

${ }^{134}$ See Substance of the Report from page 5 forward; see also The Times 6 January 1792, 3 B and 
should be read, which when the signature was mentioned by the Clerk, as the mark of King Tom, created much laughter in the House.

Here The Times both names and diminishes the African — a King, but then a Prince: one who assigns lands to the British King but cannot equal British royalty, and so must be merely a Prince; one whose deed of land should be read, but who is mocked for his limitation of making a mark rather than a signature. Cawthorne's ridicule specifies Africans as second-tier citizens who are funny because they do not know they are second tier, and the apparently uncontested laughter in the chamber confirms his rhetoric, as does its reporting by The Times.

The deed itself was the 11 June 1787 treaty with King Tom, and The Times reports its reading to Parliament. Its text reveals a tension between that British condescension and an explicit acknowledgement of political structures and reason, entities challenging those sensibilities of African inferiority and seeming to limit the extent to which Africans could be depicted negatively (despite their regular enslavement by British traders). While the document claims to be the voice of King Tom, its composition is attributed to Bouldon Thompson ${ }^{135}$ and at the time was therefore one of the most publicly performed British rhetorics about Africans and Africa. It reads,

Know all men by these presents that I King Tom, chief of Sierra Leone on the Grain Coast of Africa, by and with the consent of the other Kings, Chiefs, and Potentates subscribing hereto, in consideration of these presents, as by a list annexed, now made me by Captain Bouldon Thompson of His Britannic Majesty's Ship Nautilus, Joseph Irwin Esqre and the Revd Patrick Frazer on behalf of and for the sole benefit of the free community of settlers their heirs and successors now lately arrived from England and under the protection of the British Government, have granted and by these presents do grant, and for ever quit claim to a certain district of land for the settling of the said free community to be theirs, their Heirs and successors for ever, that is to say, All the land, wood and water which is contained from the bay commonly called Frenchman's Bay but by

${ }^{135}$ Ibid., 112. 
these presents changed to that of St. George's Bay, coastways up the river Sierra Leone to Gambia Island and southerly or inland twenty miles. And further be it known to all men, that I King Tom do faithfully promise and swear, for my chiefs, gentlemen, and people, likewise my heirs and successors, that I will bear true allegiance to His Most Gracious Majesty King George the Third, King of Great Britain, France and Ireland etc. etc. and protect the said free settlers his subjects to the utmost of my power against the insurrections and attacks of all Nations and people whatever. And I do hereby bind myself, my Heirs and Successors, to grant the said free Settlers a continuance of a quiet and peaceable possession of the Lands granted their Heirs and Successors forever.

In witness whereof I and my chiefs have set our hands and seals the eleventh day of June.

Witness to the executing the $[$ sic $]$ above and the presents made -

Thomas Bouldon Thompson

Joseph Irwin

Patrick Frazer, A.M.

The mark of King Tom
X
Chief Pabongee
X
Queen Yammacouba
X $^{136}$

In spite of the derisive laughter discussed above regarding King Tom's illiteracy and Cawthorne's criticisms of his "assignment... of the lands," what is not contested is the way the treaty composes Africa or Africans. Africa is once again discussed as the "Grain Coast of Africa," as "Sierra Leone," as dividable into a "district of land," designated geographically but not evaluated specifically. Furthermore, when King Tom refers to defending these "Lands" against other "Nations," it allows for an interpretation of "Nations" as referring not only to the French, but also to neighboring African nationsAfrican political entities. This is furthered by Bouldon Thompson's reference to the “other Kings, Chiefs and Potentates," “the chiefs, gentlemen, and people," King Tom's "heirs and successors," not to mention the very fact of the need for a Treaty in the first place. The legalese of Bouldon Thompson (as proxy for the St. George's Bay Company) recognizes explicitly the existence of political and legal structure in Africa, something

${ }^{136}$ Qtd. in Fyfe, Sierra Leone Inheritance, 112-113. 
not contested by Parliament. While the authority of King Tom to negotiate with King George as equals is contested, and while King Tom's illiteracy is found laughable, Cawthorne does not reject the legitimacy of an African leader to lead his own people nor the social organization described in the treaty.

After the third reading of the Bill, a vote was taken with 87 members for and 9 against. On 31 May 1791, the Sierra Leone Bill passed, bringing into existence the Sierra Leone Company, and with it the first official British colony on the African continent. Through the reporting of these political and legal decisions in The Times, the consistency of rhetoric about Africa and Africans through the particular example of Sierra Leone begins to take shape.

Africans continue to be represented through condescending but not derogatory, overtly negative, or dehumanizing descriptions, when they are represented at all. And Africa itself is described mostly geographically, with other descriptions being either promotional of its viability for settlement or questions about that viability due to health concerns. This is no longer the use of such rhetorics by a lone opportunist to a committee of social welfare patrons; rather, it is by the leadership of the land reported in the prominent news outlet of the time. Therefore, these descriptions of Africans and Africa coming to light in the conversation of Sierra Leone arguably begin to be part of mainstream rhetoric about Africa in the late- $18^{\text {th }}$ century.

Additional interests become involved, however, as the Sierra Leone Company with its Parliamentary charter now in tow sought a broad variety of investors to support the expansion of the settlement by way of the emigration to the colony of Black Loyalists who had fled to Nova Scotia after the American Revolutionary War. The Company's 
promotional documents - based on further explorers' accounts—echo those rhetorics of Smeathman and Parliament, further arguing the rhetorics' pervasiveness.

III. Sierra Leone as Company and the Rhetoric of the Corporate Document For a full eight months after the Sierra Leone Bill's passage, The Times makes no mention of Sierra Leone. When it reappears on 26 January 1792, the discussion is of the preparations of the ships setting out for "the new settlement of Sierra Leone." Sierra Leone is still referred to as being "on the coast of Africa," and to that end, ships were "sitting [sic] out from Bristol... with all kinds of implements for building, and with tools for carpenters, joiners, blacksmiths, and other trades, as well as with instruments for cultivating the ground, which is represented as remarkably fertile." In the interim between the passing of Bill and the arrival of the Nova Scotian Black Loyalists, the Company held meetings of its directors as a formally incorporated entity, one product of which was a 60-page publication printed for each of its "Proprietors," entitled Substance of the Report of the Court of Directors of the Sierra Leone Company to the General Court, Held at London on Wednesday the $19^{\text {th }}$ of October, $1791 .^{137}$ The Times' reference to land "represented as remarkably fertile" was a quotation from this report, as was much of The Times' coverage thereafter. The Report itself amalgamates other key sources including reports from Lt. John Matthews, Alexander and Anna Maria Falconbridge, and

\footnotetext{
${ }^{137}$ The authorship of the Report is somewhat unclear. The document itself is unattributed. Most academic search engines refer to it as authored by the Court of Directors of the Sierra Leone Company, whereas Recoveredhistories.org, a web-based compendium of scans of anti-slavery historical documents attributes it to Alexander Falconbridge, although without explanation. Given Falconbridge's uneasy relationship with the Company after his return and reporting from his first voyage to Sierra Leone (as documented in Fyfe's edition of A.M. Falconbridge's Narrative) it seems unlikely that he would be responsible for preparing the investors' prospectus that the Report was intended as. Fyfe, Curtin, Ferguson, Coleman, and others remain silent on the issue, and I have followed their approach here, leaving the authorship as generally associated with the Company itself.
} 
of course Henry Smeathman, making it a key intersection of experience, investment, and public considerations for Sierra Leone. As such, the Report sets out in precise terms the nature of Sierra Leone and its people, echoing the rhetoric of Africans and Africa found in Smeathman and The Times. As with these other sources, the Report is alternately generally ambivalent or condescending towards Africans, although at times it is simultaneously more specific than the Parliamentary debates or Smeathman. Similar to the preceding sources, it also describes Africa in either geographical or optimistic terms.

The formal section titles in the Report-i.e., Climate, Population and Government, Religion and Morals, Cultivation and Trade, State of the Slave Tradesuggest a positive outlook: that they establish the presence of "government, religion and morals, cultivation and trade" 138 of Africans is the recognition of a certain kind of social organization. ${ }^{139}$ Furthermore the Report increasingly refers to Africans by name and title, such as when it mentions "King Tom, the then neighbouring chief" to the colony site, "King Naimbanna, the king of the country," "King Jammy (successor to King Tom) the neighbouring chief," or "Signor Domingo, Chief of the nearest town on the contrary side to King Jammy's." ${ }^{140}$ And so rhetorically, they are constructed as people with not only individual identity, but also as having political significance to their own people, and recognized by the British. While the level of title (i.e., hierarchies of kingship) is

\section{${ }^{138}$ Substance of the Report, 2.}

${ }^{139}$ This is not to argue that British rhetorics of inferiority meant they were free of stronger racial prejudice: the Report quickly refers to "the streets of London swarming with a number of Blacks" just prior to the first Sierra Leone settlement attempt in 1787. Clearly "Blacks" are those that "swarm"; just a few sentences later, those Poor Blacks are "unhappy objects." And it was their fault for the demise of the first Settlement - "They were extremely unhealthy, chiefly from disorders brought on board with them, which appear to have been aggravated by excessive drinking and other debaucheries" (Substance of the Report, 3-4). Rather it indicates that the British were to this point unclear of precisely what to make of Africans and how to represent those who were not already under the yoke of the Atlantic slave trade.

${ }^{140}$ Substance of the Report, 3, 4, 6, 36. 
somewhat blurred in the Report, and while the respect accorded to these kings pales compared to that of King George (recalling the laughter in Parliament at the "mark" of King Tom), the explicit hierarchy of status in Sierra Leone governance is not contested, which reveals British recognition of African capability for social organization.

This is elaborated further in various explanations of Sierra Leonean governmental and civil organization. As the Report explains, the Sierra Leone Company settlement site is adjacent to

several towns, consisting of scarcely more than fifty houses each. There is generally some chief who is a principal Slave Trader, presiding in the town, who is subordinate to King Naimbanna. The King lives at the small island of Robanna...The inhabitants of Robanna, about fifty in number, are fed by King Naimbanna's bounty, and are entirely dependent on him. The present King is of a peaceable disposition, and is generally respected and obeyed: his territory is said to reach three days journey up the country, being much more populous in the more interior parts; but neither the boundaries of his country, nor the nature and extent of his jurisdiction appear to be at all clearly ascertained. ${ }^{141}$

Here, the Report constructs an image of Africans who possess a clearly delineated power structure known and adhered to by the community to the extent that any population follows its own rules (note the word "generally" in reference to obedience of the people to their king). Simultaneously, the Report critiques the limitations of African knowledge of their own political borders and accompanying "extent of jurisdiction," a reiteration of the ongoing British condescension towards Africans couched in language acknowledging aspects of African culture and social organization. Africans are not represented as equals, but they are constructed as people who can be represented in a British lexicon of governance.

${ }^{141}$ Ibid, 13-14. 
This impression of the structure of the Sierra Leonean monarchy is further elaborated when the Report explains that the "chiefs who chuse the king generally pay regard to hereditary succession." ${ }^{\text {142 }}$ The Report further mentions the king's "eldest son, now in England" and that he "sent one son to France for instruction; another is educating under a Mandingo teacher, who is a Mahometan"; furthermore, "One of the Sierra Leone Chiefs sent his son to a Portuguese settlement, at Biziagos, three hundred miles off, that he might learn to read and write." ${ }^{143}$ The Report suggests as well that intercourse with European knowledge is already underway, as "the secretary of King Naimbanna, of the name of Elliot, learned to write and read in England."144 It must be remembered, however, that this is British rhetoric, something Fyfe clarifies when he explains that Naimbana was merely "styled King by the Europeans" and "was in fact regent, not king, over the Koya Temne, who peopled the southern shore of the estuary."145 Significantly, British desire constructed Africans as people able to understand British governance and to be influenced. This extended the viability beyond the landscape to include the people, who were promoted rhetorically to an ability to receive British influence, specifically the Company's project and plan.

Promoting Africans in this way, the Report quotes a letter from Naimbana to Granville Sharp, citing the King and his son's abhorrence of the "Slave trade; the

${ }^{142}$ Ibid, 14

${ }^{143}$ Ibid, 14-16. See also Fyfe, A History of Sierra Leone, 54-55, for several further examples of educational exchanges between Sierra Leone and Europe at this time.

${ }^{144}$ Ibid, 16. As Fyfe explains, this is Elliote Griffiths, one of the original Black Poor to set out on the first British attempt at settlement of Sierra Leone, "one of the Granville Sharp settlers" (see also Falconbridge, Narrative of Two Voyages, 19; and Fyfe, A History of Sierra Leone, 23 and 29, where he writes, "Naimbana, influenced by his secretary Elliott Griffiths, was inclined to be friendly").

${ }^{145}$ Falconbridge, Narrative of Two Voyages, 19; Fyfe, A History of Sierra Leone, 19. 
mischiefs of which they see and deplore" (a sentiment conveniently aligned with the Company's controversial abolitionist stance). ${ }^{146}$ The letter paints the viability of Africans to serve the Company's plans: it intellectualizes them in that they are (counter to the reception of King Tom's mark in Parliament) literary, morally aligned with the Company, intellectually curious, and confident. Naimbana is represented as a writer (the scribe Griffiths going without mention), a leader able to consider what advantage the colony might bring, and lastly a sensate victim who has witnessed, suffered under, and condemned the institution of slavery. Having been warned by local slave traders against the Black Poor and Sharp's Province of Freedom, Naimbana instead

served them in any little request they asked of me, and have endeavoured to keep peace between them and my people, and also among themselves by settling a great many disquiets between them. It was pleasure to do it as I thought they would become useful to us all in this country, by teaching us things we know not; and common reason must tell, that the most ignorant people in the world would be glad to see their country made good if they had an idea how it might be done. And again I must let you know, that if there were no other reason for my wishing for the welfare of the settlement, I should do it that there might be stop put to the horrid depredations that are so often committed in this country by all countries that come here to trade. ${ }^{147}$

Here Naimbana does not see his own people as "the most ignorant people in the world"; rather it is his ready desire for self improvement that serves to distance the Temne from such ignorance. The Company's depiction of a reasoning, logical, anti-slavery African leader is both counter to what Smeathman refers to as "what is vulgarly imagined" of Africans and directly in alignment with the Company's abolitionist intent: that the presence of a free black colony would resist the hegemony of black enslavement.

\footnotetext{
${ }^{146}$ Substance of the Report, 17.

${ }^{147}$ Ibid., 17-18.
} 
Despite such effort to construct Africans as reasonable and organized enough to be viable partners, the Report subsequently states that there is a "want of any efficient government."148 Rhetorically, such construction of Africans might seem contradictory, yet in the Report, they are appealing logically as partners and also appealing emotionally as beings in need, making them twice fertile ground for the Company's efforts. This is suggested by the Report's sympathetic view of African leadership contrasted by a view of the citizenry that is less so. In reference to "religion and morals, the natives appear to be totally uninstructed. Perpetual feuds and hostilities seem to prevail....to carry each other off is a common mode of retaliation." 149 While the localization of slavery is rhetorically important if the Company is to recast the British as the abolitionists of a global slave trade (rather than the instigators), more important is the notion of Africans as "uninstructed," reinforcing the rhetoric of their inferiority. The Report continues with further condescension:

They are generally pagans; have no priests, no public or private worship, no religious ceremonies. They take as many wives as they please; but their marriage is not considered as indissoluble, and they give no kind of education to their children. They have some superstitions, chiefly on the subject of witchcraft; but in general are without religious prejudice, and appear extremely desirous of all kind of European knowledge and improvement. ${ }^{150}$

That they have social organization and belief systems is not contested, but rather its proximity to the sophistication of British versions of the same: and so while this belittles Africans, it keeps them on a continuum with the British, indicated in particular by their eagerness for British contribution and the accompanying ability to receive it —-thus a
${ }^{148}$ Ibid., 32.
${ }^{149}$ Ibid., 15.
${ }^{150}$ Ibid. 
maintenance of the rhetoric of inferiority and viability. In short, they need to be taught, to become students of the British. So Naimbana sends his son "thence to England, in order to gain useful knowledge in this country."151

The specific nature of that "European knowledge" is elaborated in the Report at the same moment a more elaborate rhetorical construction of the Africans takes place. In the later section of the text focusing on the "State of the Slave Trade," specific details of the hot temper of the Africans is posited as an excuse for the development of the internal slave trade, the foil to which is-delivered without any sense of irony, given the prior three hundred years of the international slave trade-British civilization, most specifically manifested in Christianity. The Report first states, "A sudden vindictive temper seems also to be common with the natives, and to be instrumental in promoting the Slave Trade."152 Exactly how such a bad temper created the slave trade is explained as follows: "This little vindictive temper seems to be joined with another evil principle. It is a point of honour not to forgive an injury, and to perpetuate private feuds between one family and another, so that they will even take each other for slaves, as they can get opportunity." 153 It is the Africans' own fault that the Slave Trade exists: were they not so vindictive, or had they a better means of settling disputes, they would not rely on it. As the Report states, "The spirit of retaliation which now subsists in Africa appears to be much the same with that which has prevailed in all other countries, before Christianity was introduced, or civilization had taken place."154 These new elements in the
${ }^{151}$ Ibid., 16.
${ }^{152}$ Ibid., 29.
${ }^{153}$ Ibid., 30-31.
${ }^{154}$ Ibid., 31 . 
conversation both complicate the depictions of helpful, peaceful Africans suggested earlier by Smeathman and alter that conversation through the first injection of a Christian agenda into it, one already intrinsic to many of the Company's founding members but buried until this time due to its correlation with abolition, a political stance avoided (as discussed above) by Company proxies in Parliament. No better justification for a pronounced Christian agenda in Africa was needed than a construction of African vindictiveness, particularly if Christianity had successfully eradicated vindictiveness wherever it had been adopted.

Such a rhetorical construction of Africans, however, is not entirely negative, at least not to the extent of the dehumanizing rhetorics soon to come in the mid- $19^{\text {th }}$ century. While the Africans may be vindictive in practice, their habit could easily be changed by the arrival of British influence or by the dispatching of the leaders' children to Europe to gather that influence and return with it. The notion of the African, then, is neither fixed nor limited: they are inferior, yes, but viable, possessing enough agency to circumvent and terminate the slave trade upon mere instruction by their British partners. And the Report suggests this desire is already in place: the King and his son, it explains, "have the strongest desire to rescue their country from its present state of ignorance and wretchedness; and also to put an end to the slave trade; the mischiefs of which they see and deplore." $" 155$

Significantly, in reference to slaves, the Report states that "King Naimbana has 120 of these, who take half the produce of their labour for themselves" ${ }^{, 156}$; according to

\footnotetext{
${ }^{155}$ Ibid., 17.

${ }^{156}$ Ibid., 30.
} 
the Report, even slaves are "who," as opposed to that, which is to say that even they-the lowest of Africans - are still people. Furthermore, intermingling with the mentions of vindictiveness are complimentary depictions of the Africans' empathy and hospitality from Matthews' and the Falconbridges' accounts, seemingly intended to reiterate the strong potential for the Africans to follow the British lead towards civilization:

Though the Africans are vindictive to their enemies, Lieut Matthews observes, that, "to their friends they are hospitable and kind," and that "he received such treatment from them, in the time of the utmost distress, as he could have expected only from his best and nearest friends." (Voy. p 96) Mr. and Mrs. Falconbridge in like manner, speak of having experienced the greatest hospitality and kindness from the natives. The latter says, that the women were most uncommonly attentive and obliging to her, and seemed to vie with each other in their endeavours to render her situation comfortable. ${ }^{157}$

Such a regard for African potential suggests a British image of likely candidates for assistance who are nearly where they should be and only need the presence of the Company and its plan for an island within Africa—where slavery would no longer exist and where Christian morals would be introduced - in order to join the company of the civilized world. Such a rhetorical belittling of the Africans was essential, if the Company were to justify its existence in this case not to Parliament (that challenge having already been met) but to investors, for whom the Report was prepared and published.

One final note regarding the rhetorical construction of Africans in the Report is the way in which they are referred to generally, when an individual is not being spoken of by name. Africans are mentioned as "natives" throughout, but also as "man" or "he," as well as "the person," and as already noted, simply as "Africans." "158 Along the lines of

\footnotetext{
${ }^{157}$ Ibid., 31.

${ }^{158}$ For example, see Substance of the Report, 21-24, 26; 29-30; 31.
} 
the rhetorical trend of the late- $18^{\text {th }}$ century, these words appear either entirely unadorned by modifiers, left generally unmarked linguistically. ${ }^{159}$

When it comes to rhetorics of Africa itself, the Report constructed for potential investors an image of the continent in general, and the Sierra Leonean corner of it in particular, in line with Smeathman's rhetorics of Africa. ${ }^{160}$ It is necessarily positive; however, it is specific in several aspects presumably meant to be pleasing and enticing to those investors and their questions regarding viability and profitability. While there was no money to be made in abolition itself - and as the Parliamentary debate covered in The Times reveals, much fear existed about money to be lost— the Company sought to change the direction of the financial discussion on Africa from taking people to trading with them, a discussion contingent on a productive and consumerist Africa. Coleman writes of this ideological shift underpinning the formation of the Company:

Sierra Leone was set up to serve a number of purposes. It was to be an act of atonement for the slave trade, a key weapon in the fight to undermine the entire system of slavery, and a model to the rest of Africa of what could be achieved in terms of untainted commercial transactions with the rest of the world. The charter of the new Sierra Leone Company declared that, "they will send out goods from England and take all kinds of African produce in exchange; that they will not deal in slaves themselves, nor allow of any slave trade on their ground."161

${ }^{159}$ The Falconbridges' description of them as "vindictive" demonstrates this inconsistency perfectly, in that their adjective is not regularly used by writers about Africans in this period. Such inconsistency is precisely what makes it difficult to portray the rhetoric simply and concisely, which both reveals the varied nature of British sensibilities about Africans during the rise of Abolition and establishes a vivid contract with the focused and concise rhetoric of Africans soon to come with the arrival of Liberia.

${ }^{160}$ See Coleman, who writes, "Sierra Leone was the brainchild of an eccentric botanist, Henry Smeathman, who had grandiose mercantile ambitions about an African commonwealth in which ex-slaves would grow rice, sugar, cotton and other commodities, thereby opening a channel of trade and commerce with Britain" ("Sierra Leone, Slavery, and Sexual Politics," 4).

${ }^{161}$ Ibid., 5. Coleman quotes the Company Charter from Meacham, Henry Thornton of Clapham, 104. 
Those "untainted commercial transactions" - commerce free of slavery of any sortrelied on an Africa rich enough in resources as well as productivity that it was capable of generating "all kinds of African produce," in surplus.

At stake in the Report therefore is an image of Africa as a place of plenty, much as Smeathman had already described, but one also ready to be manipulated into becoming a manufacturing economy. To that end the report quickly lays out an image of geopolitical order: "King Jammy’s town," "Bob's Island," and "Par Boson's Town,” and another "former town," 162 it explains, border the colonial territory, the final town being described as "some deserted houses" and that "about four acres of land were already cleared round the town, and planted with yams and cassava." ${ }^{\text {163 }}$ The Report later explains that "a number of towns are now standing without inhabitants on the sea coast, two of which Mr. Falconbridge has seen: they have been all broken up by Cleveland, a very great mulatto slave trader, who was educated at Liverpool."164

Arguably what this information constructs for the potential investors is an image of a settled, agrarian landscape, something intrinsic to the sort of viability proposed in the Report (as opposed to nomadic regions which—while viable for trading partnerships, like certain North African areas-would not tend to support rice or sugar production). And at the same time it portrays an Africa that is organized at least loosely into political territories. The criticism heaped upon both local slave trading (Cleveland) and the scourge of the British slave trade that Liverpool had become was a critique of slavery as

\footnotetext{
${ }^{162}$ Substance of the Report, 6-7.

${ }^{163}$ Ibid., 7-8

${ }^{164}$ Ibid., 34 .
} 
something that had undone a local community that had once been organized enough that — had it remained — would have been useful to the Company.

This rhetoric of human geography was essential to the vision the Company sought to promote of Africa, but alone it would not create a counter to the thriving agricultural production of the West Indies. Ideal climate and fertility of land were equally necessary, and to that end the Report reiterates the Edenic notion of Africa painted by Smeathman, but with much greater elaboration (it is from here that The Times draws its specific wording). "All the most valuable productions of the tropical climates," the Report states, "seem to grow spontaneously at Sierra Leone."165 Furthermore, it states, "The climate may be reckoned to be much the same in point of heat, as that of the West Indies; but there is a very cool sea breeze on the higher grounds; and on the mountainous parts it is believed that a very temperate air may be found." 166 And in a twist counter to the original complaints that led to Botany Bay instead being selected as the penal colony, the Report contends that "the climate of Sierra Leone is extremely favourable to the natives themselves, and no [sic] otherwise unfavourable to the Europeans than other climates of the same latitude." 167 The depiction of Africa in the Report echoes depictions in The Times and Smeathman's Plan, all of which employ what had become a normative way of discussing Africa—either according to its geographic traits or its fertile, productive landscape.

\footnotetext{
${ }^{165}$ Ibid., 27.

${ }^{166}$ Ibid., 9.

${ }^{167}$ Ibid., 11.
} 
Demonstrating that rhetorical continuity, the Report quotes Matthews from his Voyage to Sierra Leone, who writes, "If properly cleared and cultivated, would be equal in salubrity, and superior in cultivation to any of the islands in the West Indies."168 Reflecting the pervasive nature of this rhetoric, when the 26 January 1792 coverage from The Times refers to the soil being "represented as remarkably fertile," it quoting the Report's own quotation of Matthews' Voyage, when he writes that the "accounts afforded in geographical books very much correspond.-The country 'about Sierra Leone' being observed to be 'one of the best in Africa, and the soil very fertile." "169 The Report concludes, "Nature appears to have been extremely liberal, and to have poured forth her treasures with an unsparing hand," the word treasure a rhetorical signifier for prospective investors. ${ }^{170}$ Africa's ability to make fortune outside the slave trade draws attention to the potential of the place itself, which is new ground for the British.

The specifics of cultivation and production are further promoted, suggesting an even richer, grander image of Africa than hitherto conceived, and one well beyond the West Indies. "No country produces more variety of excellent and beautiful timber fit for every purpose," the Report states. The "palm trees which furnish the natives with both wine and oil, flourish here in great plenty and perfection. Wild geese and ducks of various kinds, Guinea hens, pheasants, quails, curlues [sic], plovers, snipes, doves, and pigeons, are found in the woods and on the banks of rivers," indicating the presence of fertile agricultural production but also fecund wildlife. Domesticated fowl "would thrive

\footnotetext{
${ }^{168}$ Matthews qtd. in Substance of the Report, 25-26.

${ }^{169}$ Matthews qtd. in Substance of the Report, 12.

${ }^{170}$ Ibid., 26.
} 
here extremely well," and "most excellent fish" are to be found in the waterways and off the coast. ${ }^{171}$ Furthermore, not only might Sierra Leone replace the West Indies, but it also could reduce the need for reliance on the East: the Report speaks of "several kinds of aromatic fruit, which are excellent substitutes in culinary uses for the spices of the East." And it suggests that which has been attempted in the West Indies succeeds in Africa, for "most of the tropical fruits known in the West Indies, abound here, in the greatest perfection." Indeed, they "thrive amazingly; and nothing can exceed the luxuriancy [sic] of the wild vines, which bear amazing quantities of grapes." ${ }^{172}$ And with an eye to the export market, they have "the best indigo in the world."173 Collectively, Sierra Leone takes on the form of Paradise found, where those things which are needed "grow spontaneously almost every where."174

These echoes of Smeathman's arguments for the continent's viability maintain a view of Africa parallel to that of Africans, which is that this is the place for British endeavor - the people and place are blank enough not to interfere, but fertile enough to be brought to fruition. While Sierra Leone is the land of milk and honey, it is being utterly neglected by the Africans themselves. Thus the Company is needed to guide them towards freeing Africa from the constraint of its own untapped potential. So when the Report makes the claim that "Nature appears to have been extremely liberal, and to have poured forth her treasures with an unsparing hand," it immediately follows, "but in most cases, the indolence of the natives prevents their reaping those advantages, of which an
${ }^{171}$ Ibid., 21-22.
${ }^{172}$ Ibid., 25.
${ }^{173}$ Ibid., 23.
${ }^{174}$ Ibid., 26. 
industrious nation would possess themselves." This justification for the Company's plan for Sierra Leone is clear: Britain is the "industrious nation" to avail itself of the treasures poured forth or lead the new colony to do the same.

Such arguments regarding the local Africans and their unavailing relationship to Africa continue throughout the Report's promotion of the continent's bounty. Those domesticated fowl "would thrive" only "would the natives be at trouble to rear them. And it is not a little surprising that the Guinea fowls... should be neglected by them." Further evidence of this "indolence" is offered regarding "tobacco, which is not esteemed, owing perhaps to their want of knowledge in the cultivation," 176 or cotton, "which is cultivated by the natives, but in no greater quantity than they can manufacture themselves." ${ }^{\prime 177}$ The discussion of the latter is interesting because it continues with speculation about the transition from the current use of cotton—only growing the quantity needed for the cloth required locally ${ }^{178}$ - to the speculative future envisioned by the Company, which would "induce them to propagate it to such an extent as to become an article of European traffic." 179

And this is the direction towards which the comments regarding native indolence appear pointed: that for those "most valuable productions...nothing but attention and cultivation appear wanting, in order to produce them of every kind, and in sufficient

${ }^{175}$ Ibid., 22.

${ }^{176}$ Ibid., 24.

${ }^{177}$ Ibid., 23.

${ }^{178}$ A claim entirely contradicted by Mungo Park, who documented the export of cloth from coastal and savannah Africa north to the Sahel. See Park, Travels in the Interior of Africa, 167.

${ }^{179}$ Substance of the Report, 23. 
quantities to become articles of trade, and even of great national concern." ${ }^{\text {180 }}$ This

conflation of the problem of native inefficiency discussed earlier and reiterated here with the potential for reforming the European relationship with Africa from slave-based to product based serves rhetorically to construct the Company as the panacea for African problems. And it is Sierra Leone that could achieve these lofty goals, for at

Sierra Leone...that country... a coast and river trade, and, through the rivers, an important inland trade, may easily be established by means of small vessels calculated for that purpose: These might deposit at Sierra Leone productions of Africa, brought from other parts. The coast of Africa, neighbouring to Sierra Leone, is more intersected with rivers navigable for small craft, than any other portion of it whatsoever: by which circumstance an extensive commerce might be greatly facilitated. ${ }^{181}$

Rhetorically, the Report works to identify the needs which the Company might meet as well as the means by which it would accomplish them, constructing itself as a compelling investment to the London elite; it is the perfect corporate document. Within its language is a reiteration, however, of descriptions of Africa and Africans that both elaborated on prior rhetoric from Smeathman and The Times and maintained their basic premise of a blank but fecund Africa ${ }^{182}$ and inferior but mutable Africans which collectively made for viable recipients of British intent. The Company sought investors through the Report because in the autumn of 1791, the colony remained anything but certain. 1792, however, was the year in which this changed altogether, when the second great wave of immigration into Sierra Leone took place and it was finally permanently established. The

${ }^{180}$ Ibid., 27.

${ }^{181}$ Substance of the Report, 27-28.

${ }^{182}$ The viral nature of fecundity being downplayed, given the document's goal of securing investment. Those health concerns raised by the Committee for the Relief of the Black Poor in response to Henry Smeathman arise again in the experience of the second wave of settlers whose struggle with illness echoed that of the first wave. 
coverage of that year in The Times brought an enormous amount of fresh detail of Africa and Africans, in which the rhetoric produced thus far pervaded still.

IV: Success in Africa: The Times' Ongoing Relationship with Early Sierra Leone With the arrival of the Nova Scotia Black Loyalists, Sierra Leone as a colonial effort achieved what the Company and its predecessors had envisioned: a permanent settlement on the Grain Coast by Anglicized blacks who might carry out their various agendas. Africa and Africans at this point shifted from being points of speculation in London to ongoing, evolving realities for the Company and for the British public at large. This was both limitation and opportunity—limitation, such as when the colony was assaulted by the French Revolutionary navy in 1795 and nearly burnt to the ground, and opportunity, such as the ability of Company officials to sort out the actual details of maintaining, expanding, and acculturating a new pocket of Britain on the continent. ${ }^{183}$ This also meant learning through experience rather than by proxy: many more British civil servants and Company officials had regular contact with Africa and Africans outside the specter of slavery, and these interactions were reported regularly in The Times.

The coverage in The Times of the second — and finally successful—wave of immigration in the year 1792 in particular reads like the culmination that it is of nearly a decade of discovery and exploration. The articles work like a traditionally-wrought narrative with all the tension and anxiety of unfulfilled desire, a querulous climax, and a conclusion that seems written to - and in fact does - put the discovery and establishment

${ }^{183}$ See Kup: "The 1794 directors' report speaks of the land in Sierra Leone 'as actually purchased and given up, by the native chiefs...so that it is not only an English settlement, but an English territory, where all the free customs and rights of the English common law immediately take place." Kup continues, "The 1794 report said that the directors "considered, as they were bound to do, that the British Constitution, as far as it is applicable... is transferred thence"” ("John Clarkson and the Sierra Leone Company," 212). 
of Sierra Leone to rest for the foreseeable future. Within the momentous year-long chronology, however, the descriptions of Africa and Africans follows the rhetorical trends practiced to this point. Africa continues to be depicted as a generalizable place about which much is hoped, in terms of its potential for agriculture, much is fantasized, in terms of its imagined Edenic plenty, and much is feared, in terms of its unhealthiness. Africans themselves are equally generalized, and at first described simultaneously as inferior and potentially dangerous; however, they come to be constructed as remarkably reasonable, even helpful at times, and lastly as friendly. Rhetorically then, 1792 in The Times reflects the typical rhetoric of Africans and Africa in the late- $18^{\text {th }}$ century: a generalizing and condescending tone at first that evolves apace through direct experience into a mix of regard and continued overall ambivalence.

The coverage from early in 1792 does little to concretize Africans; rather, it hearkens back to the debates of the previous spring of 1791, particularly reiterating the financial prospect that Sierra Leone primarily was to many of the investors in the company: "by the beginning of the ensuing year," The Times states, "the Company will have 2000 acres planted with sugar canes. The natives of the country are to be engaged to work for hire." 184 It also explains the means of land distribution for settlers (as discussed in the Report), which will ensure they are both landed and productive: "To the people who go out from hence, tracks of land are to be assigned." ${ }^{\text {185 }}$ The assumption of this statement- the simplicity with which land could be assigned—reiterates that rhetoric

\footnotetext{
${ }^{184}$ The Times, 26 January 1792.

${ }^{185}$ Ibid.
} 
of an Africa in which one could simply arrive, acquire land, and move in without disrupting or displacing anyone in any meaningful way. ${ }^{186}$

On the other hand, the Company wanted, The Times reports, to do "justice to the various persons, who on the faith of the Company's protection had embarked themselves and their families in the undertaking."187 On the eve of departure of actual British citizens for Africa, the use of the term "protection" reiterates this somewhat sudden anxiety in the minds of the British when faced with the reality of settling there, rather than just settling blacks there. ${ }^{188}$

Whatever fears existed of African hostility (presumably at least part of that from which the settlers must be protected) were reversed by July, where the coverage states that "some of the natives appeared at first to doubt the peaceable intentions of the Company and they had not yet lent any material assistance to the Colony"; however, "a more friendly disposition had also begun to shew itself, and the good offices of King Naimbanna had been exerted in favor of the Company."189 Here the Africans are not

${ }^{186}$ Rhetorically, however, such view of Africans is not specifically a negative one. Its ambivalent sensibilities, an Africa constructed as relatively empty, or only moderately filled by inconsequential things, is not the same as an evil, dark, fallen Africa that consumes or destroys. While this latter sort of rhetoric, common in the mid- $19^{\text {th }}$ century, is specifically negative, it might be more accurate to consider the former - the majority of what was constructed at the end of the $18^{\text {th }}$ century - as problematic or ignorant, an entirely different matter altogether.

${ }^{187}$ The Times, 10 February 1792, 3D.

${ }^{188}$ Such fears presumably included both sickness and attack. The conflict that brought about the destruction of the first settlement at Sierra Leone four years prior was retribution for the settlers' getting in the middle of a dispute between local slave traders and a chief in the area. The conflict that nearly destroyed the second, vastly larger settlement four years later was between the French and British. A further conflict that risked the settlement's destruction in 1801 came from within, as Nova Scotian Blacks protested the Company's broken promises. Such fears of attack by the local populations do not appear to be grounded in reality but rather born of a belief in a certain kind of Africa, one that is loosely threatening but can be overcome with careful, thoughtful planning and calculation.

189 The Times, 11 July 1792, 3B. 
threatening, but feeling threatened, and nonetheless becoming more compliant: such a transformation of the way the "natives" are described would certainly be in the service of the Company, which by necessity needed to report an ability to maintain security as well as curry favor with the locals. This shift from fear of hostility to a more hopeful, expectant ambivalence correlates with the shift from anxiety of what will happen in Africa to ambivalence towards what had happened after a few months there, that ambivalence revealing a return to the rhetorical trend of this period. If anything, the depiction of Africans in this report depicts them as no impediment, as Smeathman had originally suggested.

The more the British encountered Temne, Mande, or Foulah peoples, the more sympathetically they reported on them to the press in London, a fact emphasized later that year in a report reaching The Times of a local leader in Sierra Leone who abolished slavery. Equating the leader's political consciousness with that of the newly minted United States as well as revolutionary France, The Times states,

It should seem that every people on earth had given the signal for operating some great change in their governments....Alkadi, who had been named Chieftain, by 15,000 of his countrymen, has published a proclamation as follows:- "No war with our neighbours - at least no unjust attack on them. It is prohibited under pain of death to sell a prisoner, or to deliver up a man who has escaped from the sword of war, or from bondage." Alkadi then will no longer deliver up his equals to European traders:- he will buy his guns, his powder, his ball, and give ivory in exchange. It is said that this resolution has produced wonderful good effects, and that agriculture flourishes....If such a spirit of philosophy gains ground on the coasts of Africa, the Antilles will be soon deserted. ${ }^{190}$

In this reporting of African Abolition, Africans fulfill the Company's rhetoric of them, not merely because a chief has decided to end the practice of slavery, but also because Africans are confirmed as those among whom philosophy can take hold. This was

${ }^{190}$ The Times, 26 November 1792, 2B. 
perfect alignment with British intention: already, Africans had renounced vindictiveness and copied British morality. The Times was clearly willing to elaborate its rhetoric of Africans according to the new details it received; however, it should be noticed that this depiction of Alkadi, ${ }^{191}$ rather than being a depiction that elevates the image of Africans, is reframed at the end as testimony of British success, the result of the British "signal" reaching the continent: Africans even when at their best remain rhetorically merely a viable tool for British intent,

The concluding discussions of Africans in The Times near the end of 1792 portray the settled nature of Sierra Leone, writing of the "Company's Mineralogist" who had "set off upon an expedition into the country" and the "Botanist...pursuing his researches," presumably peaceful pursuits undertaken in a suggestively peaceful locale. Additional harmony had occurred: "The free Black inhabitants of Granville Town (who went from England five or six years ago) had been united in some measure with the Nova Scotia Blacks." 192 All was coming together, including the helpfully "perfectly friendly" natives who continued to be both friendly and little else. They "often flocked to Free Town, though no regular trade with them had been opened, nor had any material advantage been yet derived to the Company from their labour." ${ }^{193}$ Now understood to be aligned with British morality thanks to the exemplar of Alkadi and indisposed to cause problems for British colonization thanks to a peaceful year, Africans themselves seem to have taken on less relevance than ever before, not only losing any specific identity by the end of the year, but also rhetorically being conflated simply with potential for Company profit.

\footnotetext{
${ }^{191}$ Perhaps a confusion of a Muslim title for his name.

${ }^{192}$ The Times, 4 December 1792, 3B.

${ }^{193}$ Ibid.
} 
Rhetorically, by the end of the first year of robust British contact, this is not a particularly negative portrayal of Africans, nothing condemning them or painting them as evil, inhuman, or fallen, as they would come to be depicted in the next century. Instead, they continued to be largely constructed as they had been since Smeathman, which is to say stripped of their personhood and refilled with market value. Yet, such a construction is not exclusive, but rather is accompanied by the specified coverage of the chiefsNaimbanna and Alkadi. And so a complicated, at times contradictory vision of Africans remained in place. These late- $18^{\text {th }}$-century rhetorics of Africans indicated an ongoing British practice of subsuming the African identity by dominant British interests or reviving and highlighting it, depending on the British need of the moment. In either case, Africans remained malleably in the service of British interests, a trend utterly in contrast with the $19^{\text {th }}$ century, when representations of Africans became more specific and consistently repeated. With no such fixity suggested in British conceptions of Africans during the founding of Sierra Leone, the trend rhetorically was to remain flexible in the way one conceived Africans so that they could first be feared, then be befriended, and then converted ideologically, but always reframed according to viability for British interests. Arguably, then, the work of The Times in 1792 on Africans was to complete their rhetorical conquest.

To the extent that Africans were brought under British rhetorical control at the outset of successful settlement of Sierra Leone, Africa itself was worked in a similar rhetorical process. In the course of the year's coverage, Africa is introduced with great hope, dismissed during the rainy season as utterly problematic and hopeless, and redeemed once a clement state returns. 
While the emigrants from Nova Scotia began to arrive in Sierra Leone in February 1792 and continued to do so for several weeks thereafter, The Times makes no mention of the colony until mid-summer, at which point it refers to "the fever which the free Blacks had brought with them from Nova Scotia, and which had also carried off several of them after their arrival in Africa." But the coverage further explains that it "appeared to be entirely stopped and the whole Colony was in remarkable good health"; and while two whites had died, "Neither of these deaths could be attributed to the climate." 194 In the rhetorical pattern of writing about Sierra Leone, this repeats the trend of writing Africa as an entirely unadorned noun, without any sort of modifier, and goes so far to preemptively counter any suggestion of problems with the climate. The cloud of illness was something brought with the blacks from the New World, symbolic of their struggle and their misplacement there; matters are alleviated, not exacerbated, by arrival at Africa and thus Africa is, at least for the blacks upon arrival, a place of healing, echoing the trend of depicting Africa as a place of growth. Interestingly the cause of the whites' deaths is merely treated in the negative - it was not a matter of climate — and so Africa cannot be to blame.

Similarly Africa continues to offer "fish, vegetables, and fruit...in tolerable plenty," and the "settlers had begun to sow a variety of seeds," while the "Company's Manager had collected a few sugar canes together, with a view of beginning a plantation.” ${ }^{\prime 195}$ The transplanting of that familiar structure of British human geographythe plantation - suggests that an Africa limited rhetorically to agricultural viability

\footnotetext{
${ }^{194}$ The Times. 11 July $1792,3 \mathrm{~B}$.

${ }^{195}$ Ibid.
} 
provides a more or less blank slate (or at least an entirely malleable one) necessary to recreate the productive New World agricultural model without the problems of slavery.

By late summer, however, this vision of Africa represented in The Times recedes, in large part because "the rains began to set in" and "a considerable degree of sickness and mortality had prevailed from that time." 196 The Times laments that "Sierra Leone and its settlement we fear, such is the pestilential tendency of the climate, will never answer the end proposed by the benevolent proprietors, who however fairly deserve, though they cannot command success." ${ }^{\prime 197}$ The reality of increased malaria occurrences as well as intestinal tract infections and other illness increased by the near-equatorial rainy season challenged the Edenic imagery of Africa; however, the editors of The Times for the first time suggest an adjective to associate with Africa, even if only referring to its climate: "pestilential" denotes evaluative implications different from the use of a term such as difficult or challenging, reiterating that there is something inauspicious about Africa, something better off if under British control. What precisely is not named, but it appears lurking under the surface, hinted at by the use of such terms.

In a fascinating reversal, however, just a few months later, The Times returns to its original interest from years earlier in the soil of Africa. The coverage at this point suggests that in spite of the fact that

no African produce had been collected, nor any general trade to Sierra Leone as yet begun...the rains... proved upon the whole much less severe than was expected; and the climate (notwithstanding the great number of deaths among the lower Whites) was thought upon the whole to be quite as good as that of other

${ }^{196}$ The Times, 24 August 1792, 4A. To that end, the nature of Africans themselves shifts in light of such overpoweringly bleak community illness from the kinds of specificity extended before to a simple statement that "the natives appeared to be extremely friendly."

${ }^{197}$ The Times, 3 September 1792, 2D. 
uncleared and unimproved tropical countries. The soil, where it had been cultivated, proved in general extremely productive. ${ }^{198}$

The climate of Africa, once acclimated to and brought under control, is in the end endorsed, concluding with a reversion to the same rhetorical trend since the days of Smeathman, invoking even his language about soil fertility. Reporting on dispatches from Sierra Leone House (the company headquarters in London), The Times states that "the Colony at Sierra Leone were recovering from all the difficulties...during the rainy months. The health of the Colonists, but more particularly of the Nova Scotia Blacks, was improving... order as well as internal harmony was introduced, and the full establishment of the Colony was not questioned."199 This is in stark contrast to a pestilent Africa, or to one where the natives must be suspected of attack and preemptively defended against, indicating a willingness on the part of the press to leap quickly to negative depictions of Africans and Africa, but also the strength of the prevailing rhetoric to draw the press back to its terms once the fear of disaster is resolved.

The conclusion of the 1792 coverage in The Times of the Colony's successful establishment bookends the broader rhetoric of Sierra Leone as well, for The Times would not cover it again for three years. The recovery that accomplishes the unquestioned establishment of the Colony is not merely recovery from the rainy season and its illnesses. Rather, manifestations of internal harmony, "The institution of schools, the establishment of any hospital or dispensary, the regular distribution of lands, and the formation of a more complete and permanent town, were beginning to be entered

\footnotetext{
${ }^{198}$ The Times, 4 December 1792, 3B.

${ }^{199}$ Ibid.
} 
upon." 200 In short, a miniature Britain was coming together, reiterating the viability of Africa for British intent. Africa is not a place one marches over with an army, but rather - and this is with enormous importance in terms of foreshadowing - a place one first constructs rhetorically according to British desire and then arrives and establishes a fulfillment of that desire: a little corner of Britain. Internal harmony suggests a finding of peace between British rhetorical desire and Africa, a sustainable establishment of life on Britain's terms. Harmony means not having to be African in Africa, even if one is a Nova Scotian Loyalist of African descent.

This discovery of Africa-which is to say the discovery of an effective rhetorical construction of Africa and Africans - confirmed the Clapham Sect's first contemplations of not just a post-slavery England and New World, but a post-slavery Africa. They merely needed to invent an Africa - that Africa - first, a project accomplished by the rhetorical creation of Sierra Leone, and subsequently carried out by another invented entity: Sierra Leoneans.

\section{Conclusion}

The disappearance of significant Sierra Leone coverage in The Times until $1800^{201}$ reflects the settling of the colony, a settling of the question of the colony, and a discovered Africa. It is not that British eyes ceased to look to Africa-quite the contrary. But Sierra Leone as a central entry point both geographically and ideologically was by December 1792 established, and the ongoing exploration and discovery of Africa and

\footnotetext{
${ }^{200}$ The Times, 4 December 1792, 3B.

${ }^{201}$ With one exception: see 28 December 1795, 4A, for one of only four mentions of Sierra Leone in The Times between 1792 and 1800, and the only coverage of any length.
} 
Africans - and the accompanying rhetorical construction of the same-would from this point forward be carried out unavoidably in the context of and in relation to Sierra Leone. Thus the rhetoric of Africans and Africa through the colonization of Sierra Leone serves as a key reference point for this period of exploration of Africa between the Abolition Era and the formal colonization of the continent as a whole. And that point suggests not that the British lacked biases towards Africa and Africans, but rather that their biases were complicated by a departure from a slave-trade mindset to one of curiosity and invention, one dictated by desire as much as by the successes and failures of experience.

Regardless of any shifts or inconsistency in selection of specific terms employed in the rhetoric of Sierra Leone, the imposition of those terms and their overall representation of British desire to impose its will on Africa, rhetorically and physically, are a vivid example of the rhetorical imperialism to which Scott Lyons refers when writing of the "ability of dominant powers to assert control of others by setting the terms of debate. These terms are often definitional — that is, they identify the parties discussed by describing them in certain ways." ${ }^{202}$ Lyons writes of what was lost under such imperialism — "our lands, our languages, our cultures, our self-respect" ${ }^{\prime 203}$ —and in so doing portrays precisely what the founding of Sierra Leone meant for the Africans living near the river, the local name of which is never mentioned in any of the British documents. The extent to which Sierra Leone predicts future British (as well as American) rhetorical imperialism in Africa is the subject of Chapters II and IV, and while

\footnotetext{
${ }^{202}$ Lyons, "Rhetorical Sovereignty," 452.

${ }^{203}$ Ibid., 449.
} 
the specifics of that rhetoric undergoes two distinct turns, its nature remains utterly imperialistic. 


\title{
CHAPTER II: LIBERIA AND THE CHRISTIAN TURN IN THE RHETORIC OF
}

\author{
AFRICA \\ "Ethiopia shall stretch out her hand unto God." \\ -Psalm 68:31 \\ "Go, missionaries, be the bearers of every blessing your country owes to Africa. Be the day star of a \\ glorious morning to her benighted sons." \\ -William Augustus Muhlenberg
}

Upon the return of Sierra Leone's Governor MacCarthy from the nascent spin-off colony at St. Mary's, Gambia, the 2 May 1818 edition of The Royal Gazette; and Sierra Leone Advertiser published the homecoming dinner toast made to him by the Chief Justice. In the midst of his various accolades for the Governor, he praised Sierra Leone, "placed here as this Colony is for the purpose of diffusing those benefits and blessings over the vast but hitherto benighted continent of Africa." ${ }^{204}$ Characterizing Sierra Leone as a delivery device for "benefits and blessings" was nothing new. Referring to Africa as "benighted," however, reflected a dramatic and pervasive rhetorical turn among many of those writing about Africa in the first half of the $19^{\text {th }}$ century from how it was referred to and conceived of in the founding rhetorics of Sierra Leone.

Found in the writings of Americans observing the development of Liberia from their offices and pulpits back home, this rhetorical turn is also expressly apparent in a

\footnotetext{
${ }^{204}$ P. 4, col b (also p. 91 in bound archive); Freetown, vol. 1, No. 29.; journal was formerly the African Herald.
} 
stark turn in the way Africa and Africans are further represented in the journals of American Colonization Society (ACS) expeditions. While they invoked and repeated the trends from Sierra Leone, they also made major departures written right on top of the rhetorical constructions they invoked. First, writing of Africans generally, they depict them disparagingly, condemning their intelligence, their spiritual status, and their maturity; alternatively this criticism is aimed at faults the writers seem to find intrinsic to Africans and those brought on by slavery, leading to a benighted, degraded state, a representation pervasive to the founding of Liberia.

At the founding meeting of the ACS, for example, Congressman Henry Clay promoted "the spreading of the arts of civilized life, and the possible redemption from ignorance and barbarism of a benighted quarter of the globe." ${ }^{205}$ African American emigrationist Martin Delany argues, "The continent of Africa then, is...benighted enough, even to an apparent hopeless degeneration." ${ }^{206}$ Pro-slavery activist E.N. Elliot states in his introduction to Cotton is King, "Efforts have been, and are now being made, to extend the benefits of civilization and religion to the benighted races of the earth. ${ }^{207}$ In "Exposure of the American Colonization Society," famed abolitionist—and opponent of Elliot — William Lloyd Garrison writes of efforts "to reclaim and evangelize benighted Africa" and of "poor, miserable, benighted idolators."208 And Lydia Maria Child, one of the most sophisticated, progressive abolitionists, writes in her seminal abolitionist text $A n$

\footnotetext{
${ }^{205}$ Qtd. in Staudenraus, The American Colonization Movement, 28, but also interestingly in Walker, David Walker's Appeal, 48. States, 178.

${ }^{206}$ Delany, The Condition, Elevation, Emigration, and Destiny of the Colored People of the United

${ }^{207}$ Elliot, Cotton is King, xv.

${ }^{208}$ Garrison, Selections from the Writings and Speeches of William Lloyd Garrison, 17, 20.
} 
Appeal in Favor of That Class of Americans Called Africans (famed for chronicling arguments about slavery on the way to refuting it), "A dark cloud has settled more and more gloomily over benighted Africa. The lessons of time, the experiences of ages, from which we have learned so much, are entirely lost to this vast continent. ${ }^{, 209}$

By 1830 , these writers and others-Americans in particular-commonly modified the term Africa with a limited lexicon of synonyms (benighted being the most common) that characterized the continent and its people as having fallen into darkness from a prior state of lightness. Often anti-slavery writers used Ethiopia as a touchstone for a grand African past, one that would challenge pro-slavery claims of African inferiority. Child summarizes historical views of a sophisticated Ethiopia:

The condition of this people in ancient times is very far from indicating intellectual or moral inferiority.-Ethiopia held a conspicuous place among the nations.- - Her princes were wealthy and powerful, and her people distinguished for integrity and wisdom. Even the proud Grecians evinced respect for Ethiopia, almost amounting to reverence, and derived thence the sublimest portions of their mythology. The popular belief that all the gods made an annual visit to the Ethiopians, shows the high estimation in which they were held; for we are not told that such an honor was bestowed on any other nation. ${ }^{210}$

Moving through classical sources to medieval and more recent cases for verification, Child chronicles the basis many of her contemporaries had for believing in a once-great Africa.

This rhetorical practice for describing and relating to the continent as having fallen into darkness is noticeably different from the rhetorics of African viability focused on during the invention and development of Sierra Leone, and it would prove to be

${ }^{209}$ Child, An Appeal in Favor of That Class of Americans Called Africans, 161.

${ }^{210}$ Ibid., 141. See 141-144 for the full extent of Child's historiography (both historical and contemporary to her) of non-African thought and writing on the grandness of ancient Ethiopia. 
different yet again from the subsequent late- $19^{\text {th }}$-century depictions of Africa as the Dark Continent. That writers on both sides of the slavery debate comfortably used the same lexicon to describe Africa as benighted indicates not only the pervasive nature of the rhetoric itself, but also the assuredness which the writers felt that their readership would acknowledge and understand the specific lexicon and its rhetorical implications.

Arguably, that pervasiveness suggests much about American readership (at least readers of political and literary matters) at the time in terms of its sensibilities about Africa and Africans.

American interest in, exploration of, and writing about Africa increased substantially in the second decade of the $19^{\text {th }}$ century with the founding of the ACS and its creation of Liberia, particularly in light of the recent British developments in Sierra Leone. And the American writings, both abolitionist and pro-slavery, of the era of the creation of Liberia reveal this view of a "benighted" Africa to be generally accepted by the various stakeholders in the slavery debates. But it is the prevalence of this rhetoric of a benighted, darkened, fallen Africa among competing stakeholders that suggests the strength of this rhetorical construction: its use crosses political, racial, gender, and regional divides through the duration of its regular appearance in the first half of the $19^{\text {th }}$ century.

Echoing American religious fervor of the time, ${ }^{211}$ the use of the adjective benighted signified a privileging above all others the notion of an Africa in need of

\footnotetext{
${ }^{211}$ See, for example, Staudenraus, who writes, "In the years following the War of 1812 scores of meliorative or 'benevolent' societies were spilling over the country....part of the evangelical zeal that inspirited nineteenth-century Calvinism"; he continues, "The melioristic doctrine of benevolence, ideological ancestor of a later 'Social Gospel,' was a powerful summons for deeds promoting the general welfare....In short, the evangelical-inspired societies attempted to touch every class or group that did not fit into the ideal of a homogenous, Protestant, Bible-reading, industrious society" (The American Colonization Movement, 12, 14). Use of the term "benighted" in reference to Native Americans comes later, starting in
} 
Christian salvation, indicating a significant shift. For while the founders of Sierra Leone had repeatedly included Christianization within their catalog of benefits to be extended to Africa through colonization, it was most often limited to one-third of those benefits (the typical triad being commerce, Christianity, and civilization). ${ }^{212}$ The coming of Liberia, however, was marked by an increased moralizing in the characterization of Africa to the point that it becomes a simple matter of a Christian/non-Christian binary: Africa was not Christian and had, through the scourge of slavery, fallen from whatever grace it once held; Africans had caused their own fall by perpetrating slavery against themselves. The remedy required — given that it was those who conducted the Atlantic slave trade who now cast themselves as spiritual saviors of the Africans who were victims of it—was the forgiveness of sins which Christian salvation brought, something the Americans had, and the Africans did not.

The terminology of a benighted Africa portrayed it as having become dark linguistically, therefore indicating that it had once been enlightened; it had fallen into darkness. All of these adjectives denote a movement from a prior state of existence in Africa — not a fixed and eternal, always already status of darkness, such as that summoned by late- $19^{\text {th }}$ - and many $20^{\text {th }}$-century images of Africa simply as the once and forever dark continent, and a marked shift from the rhetorics of Africa at the founding of Sierra Leone, which placed little importance on the particulars of African existence beyond their viability for British intent. Rather, the moralizing Christian view of Africa in the early- $19^{\text {th }}$ century is of Africa as a verb—a transition—rather than a noun-a stasis.

the late 1830s with missionaries in the American West, such as the Whitmans, or in texts such as James Finley's 1859 Life Amongst the Indians or George Catlin's 1861 Life Among the Indians.

${ }^{212}$ Recalling that the initial purpose of Sierra Leone was as a dumping ground for the unwanted Black Poor of London, and had initially no determination as a proselytizing action. 
The nuanced difference is that of darkened, indicating movement, versus dark, indicating fixity.

While the use of benighted in the Sierra Leone periodical first mentioned here indicates that its use was not limited to writers on one side of the Atlantic in reference to Africa, American writers provide a potent case study of the way rhetoric about Africa evolved. The rhetoric of a benighted Africa further complicates the notion of a consistent, unchanging historical rhetoric (that "grand narrative" described by Derricourt) about Africa by revealing a substantial shift from the rhetorics of Africa during the founding of Sierra Leone. Whether the rhetoric of a benighted Africa was created by travelers, their peers at home, or vice-versa is of less importance than the presence of the overall and repeated use of the term. This interplay between the Christian zeal of the explorers (in their expressed desire to convert spiritually degraded Africans) and their counterparts back home in America (justifying their arguments on slavery through a Christian moral view of Africa) reveals the rhetorical turn from a quarter century before, a marked shift to a moralizing rhetoric of Christian conversion from the Sierra Leone venture, too wrapped up in commerce.

This chapter begins with a review of the historiography of the founding of Liberia, recognizing that creating a colony in Africa meant sending explorers who would discover those places with the potential for accommodating black American emigrants. Then it returns briefly to looking at the American use of the term benighted, more situated now as a response to Liberia. Lastly, the third and most significant part of this chapter focuses on the journals of the three waves of ACS and government agents who traveled there between 1818 and 1821, an exploration period mimicking the British model of forty years 
earlier. These American travel writings at the founding of Liberia reveal the turn in the rhetoric of Africa from the founding of Sierra Leone. Such writings helped to construct that benighted vision of Africa and Africans for those colonization activists and other Americans who encountered their (often posthumously) published volumes. Lastly further consideration will be given to the nature of rhetorical imperialism presented by the rhetoric of Liberia and what it reveals differently from such considerations regarding Sierra Leone.

\section{I: The Founding of Liberia}

As George Brooks, Jr. has explained, the concept of resettling American blacks in Africa was not new with the founding of the ACS in 1816. While many have written of the ACS or its immediate African American emigrationist predecessor Paul Cuffee, "Generally overlooked...is an unsuccessful emigration scheme undertaken by Rhode Island freedmen two decades earlier. In November 1794 the African Society of Providence dispatched one of its officers, James Mackenzie, to negotiate arrangements for the settlement of American freedmen." ${ }^{213}$ Led by Congregationalist Reverend Samuel Hopkins, "one of the first abolitionists on either side of the Atlantic to propose the resettlement of black freedmen in Africa, ${ }^{, 214}$ the Providence society sought to gain settlement allowance for black Americans in Britain's Sierra Leone, and members secured approval on repeated occasions, including from Granville Sharp in 1789, and from Governor Macaulay in 1794 for twelve families. In a 1784 letter, Hopkins states

\footnotetext{
${ }^{213}$ Brooks, "The Providence African Society's Sierra Leone Emigration Scheme," 183.

${ }^{214}$ Ibid., 185.
} 
that "there has been a proposal on foot for some time, that a number of blacks should return to Africa, and settle there," 215 and P.J. Staudenraus explains that ten years before, “in April 1773, Congregational clergyman Samuel Hopkins of Rhode Island, the chief exponent of the still novel doctrine of benevolence, called upon the Reverend Dr. Ezra Stiles, later president of Yale College, and unfolded his plan for training two missionaries for Africa." ${ }^{216}$ And by 1776, Hopkins "proclaimed that American slaves should be sent to Africa," according to Eric Burin, who further explains that in this way, "Many prominent figures hoped to conjoin deportation to abolition" in this early stage of American colonizationist thought. ${ }^{217}$

As J. Gus Liebenow states, the appeal for many American whites was not dissimilar to the British concerns about the Black Poor, albeit on a much larger scale: "Some saw emigration," writes Liebenow, "as a convenient device for ridding cities both North and South of a class that had not been successfully integrated into the American 'melting pot.' The free Black, moreover, had only a vague legal status in most states and was regarded as a constant source of social friction." ${ }^{218}$ Hopkins himself only extended his benevolence so far: in a 1793 sermon, he spoke of how resettling African Americans in Africa "will gradually draw off all the blacks...by which this nation will be delivered from that which, in the view of every discerning man, is a great calamity, and inconsistent with the good of society, and is now really a great injury to most of the white

${ }^{215}$ Ibid., 186.

${ }^{216}$ Staudenraus, The African Colonization Movement, 4.

${ }^{217}$ Burin, Slavery and the Peculiar Solution, 8. Toyin Falola also claims, "As early as 1788, the Negro Union of Rhode Island had proposed that all free Blacks should undertake a mass exodus to Africa" ("Introduction," 13).

${ }^{218}$ Liebenow, Liberia, 12. 
inhabitants." ${ }^{219}$ For as Tom Shick explains, "If human bondage was eventually to end, what would protect society from the greater dangers of miscegenation, which might follow abolition? Colonization offered an attractive solution., ${ }^{220}$ And Charles Foster echoes this assessment, stating, "Many liberal citizens had voted for the African's liberty, but nobody wanted his company." ${ }^{221}$ Despite initial British approval of American involvement once Sierra Leone had gotten off the ground, Hopkins' later refusal to certify the character of willing settlers, the early struggles of the Sierra Leone colony itself, ${ }^{222}$ and finally the ensuing American war with Britain confounded these early plans, allegedly causing "a grievous disappointment for New England blacks."223

Nonetheless, with the eventual success and stability of Britain's model, free-born African American entrepreneur Paul Cuffee took note and undertook perhaps the first successful emigration scheme for free blacks from America. Believing that "AfroAmerican emigration to Sierra Leone would help to build a black Christian nation in Africa and also suppress the nefarious slave trade," Cuffee organized, captained, and footed the bill personally for transporting 38 African Americans across the Atlantic, as well as arranged for their reception in Sierra Leone. ${ }^{224}$ In order to establish a profitable mechanism for making his resettlement effort self-sustaining, Cuffee had secured trading

${ }^{219}$ Brooks, “The Providence African Society's Sierra Leone Emigration Scheme," 191.

${ }^{220}$ Shick, Behold the Promised Land, 4.

${ }^{221}$ Foster, "The Colonization of Free Negroes," 41.

${ }^{222}$ Which Wilberforce and Thornton, in 1802 communiqués to President Jefferson, allegedly blamed on "the American Negroes [who] had caused all the trouble and save for the steadiness of the West Indian Maroons would have wrecked the colony completely." The Sierra Leone Company "wanted no more" (Foster, "The Colonization of Free Negroes," 43).

${ }^{223}$ Burin, Slavery and the Peculiar Solution, 183.

${ }^{224}$ Shick, Behold the Promised Land, 5) 
rights in exchange for transporting free, specifically skilled African Americans to Sierra Leone. But the peace treaty following the War of 1812 barred American ships from conducting trade with the British colony: Cuffee's "trading concessions had evaporated," and he found himself unwelcome in Sierra Leone as a trader and without a means for continuing his project. ${ }^{225}$

Cuffee died in September 1817, shortly after returning from Africa; however, in December of the preceding year, Samuel Mills and Ebenezer Burgess sought his advice on developing their own colonization scheme, what would become the ACS's first expedition to West Africa. ${ }^{226}$ Frankie Hutton suggests Cuffee served as a model for the ACS's philosophy that African Americans would choose emigration: "At least philosophically," Hutton writes, "he elected colonization over living as a 'free' black man in America"; furthermore, Cuffee's project revealed the "desperation felt by free blacks; a small group pooled together to willingly follow Cuffee thousands of miles to what was essentially the unknown. ${ }^{227}$ Despite Cuffee's death, the ACS hoped to utilize such sentiments for the creation of their own colony.

This early history of American interest in resettlement, emigration, and colonization is important in the overall rhetorical analysis of this project because it demonstrates the continuity between Sierra Leone and Liberia as projects within the broader continuity of Britain and America at the turn of the $19^{\text {th }}$ century, in spite of their conflicts. Framing them in this light encourages a comparison of the rhetoric of Africa

\footnotetext{
${ }^{225}$ Staudenraus, The African Colonization Movement, 10, 11.

${ }^{226}$ Ibid., 37.

${ }^{227}$ Hutton, "Economic Considerations," 377.
} 
within each colonial development as a logical critical act, given that the creation of Liberia, as will further be demonstrated, evolved directly from the creation of Sierra Leone. It would not be unreasonable, then, to suppose that the rhetoric of Africa during the creation of Liberia was informed by that of Sierra Leone. As Browen Everill has recently argued, "Although these colonies have been studied extensively...the connections between the two colonies have not. ${ }^{228}$ While Everill is particularly interested in "how [the] transnational and inter-colonial relationships" between Britain and her recently independent colonies revealed essences of empire, particularly the "relationship between 'imperialism' and 'humanitarian intervention,"” her juxtaposition of the colonies underscores how the interconnectedness of the two allows for a broader interrogation of how the Anglophone West conceived of and represented Africa. ${ }^{229}$

To the extent that Hopkins', other nascent colonization societies', and Cuffee's efforts sought to piggy-back on Britain's Sierra Leone accomplishment, the seeking of Cuffee's advice by Mills and Burgess marked a shift, for the ACS signified a recognition by certain American colonization activists that they would have to go it alone if they hoped ever to create a dependable mechanism for resettling African Americans outside of the U.S. To that end, an eclectic group of activists came together to create the American Colonization Society, including Robert Finley (Presbyterian minister and schoolmaster in Baskingridge, New Jersey), Charles Fenton Mercer (Virginia state legislator already promoting settlement schemes), Bushrod Washington (Supreme Court Justice and nephew to George Washington), Samuel J. Mills (fundraiser for the African Education

\footnotetext{
${ }^{228}$ Everill, Abolition and Empire in Sierra Leone and Liberia, 2.

${ }^{229}$ Ibid., 2, 9.
} 
Society and co-founder of the American Bible Society), and Henry Clay (U.S.

Congressman from Kentucky). ${ }^{230}$ While eventually there were "228 auxiliaries spread through all of the states... with the support of nearly all churches, ${ }^{, 231}$ the ACS was a unique invention in that it nationalized and at last unified various American ideas for colonization in one central organization. Finley, often credited with the actual founding of the ACS, set out three specific goals for colonization: "“We should be cleared of them,' Africa would receive 'partially civilized and Christianized' settlers, and the Negroes could enjoy a 'better situation." ${ }^{, 232}$ Sharing these first with friends and colleagues at Princeton in November 1816, and having consulted with Paul Cuffee himself, Finley made his way to Washington, D.C. in December of that same year for a meeting with those who would become the founders of the ACS, an act they formally agreed to on 21 December 1816 with the formation of what was at first titled the American Society for Colonizing the Free People of Color of the United States. ${ }^{233}$

Tom Shick in Behold the Promised Land echoes Finley's sentiment when explaining that the ideology behind the founding of the ACS "was the idea of complete black removal...the immediate goal of removing all free blacks and eventually the entire black population., ${ }^{234}$ And Henry Clay's famed calculations to exactly this end only serve to confirm at least partially Shick's claim: Clay "proposed to raise the ratio of whites to

${ }^{230}$ See Staudenraus, 16, 18, 27; Egerton, 159; Shick, Behold, 5; and Foster, 48.

${ }^{231}$ Foster, "The Colonization of Free Negroes," 62; see also Shick, Behold the Promised Land, 33-34 for further discussion of state auxiliaries and the ACS's attempt to rely on their financial support (the failure of which Staudenraus discusses on pp. 78-81).

\footnotetext{
${ }^{232}$ Staudenraus, The African Colonization Movement, 17.

${ }^{233}$ Ibid., 19, 27-28; Shick, Behold the Promised Land, 6.

${ }^{234}$ Shick, "A Quantitative Analysis of Liberian Colonization," 45.
} 
blacks by colonizing the yearly natural increase of the Negroes while that of the whites remained"; with the increase of African Americans estimated at a "total of 52,000," Clay projected that "an annual appropriation of $\$ 1,040,000$ with the use of 65,000 tons of shipping would carry off this excess of blacks and gradually raise the preponderance of whites from its present five-to-one proportion to perhaps twenty-to-one which would eradicate all cause for alarm." ${ }^{235}$ However, as Staudenraus explains, Clay's interest in solving race politics within the U.S. had to contend with Finley's colonization ideology, which he "urged... as a method of carrying the germs of civilization and Christianity to Africa. Viewed as a missionary enterprise, it would fix 'a seat of liberal learning in Africa from which the rays of knowledge might dart across those benighted regions."”236 "Could they," Finley pondered, "be sent to Africa...we should send to Africa a population partially civilized and Christianized for its benefit."237 That Clay soon stopped coming to Society meetings ${ }^{238}$ reflects at least partially the decision of the ACS to adopt Finley's Christian ideology over Clay's pragmatics, a result of which was the dominance "benighted" in ACS rhetoric thereafter. ${ }^{239}$

With the formalization of the ACS, but with no destination in Africa to settle African Americans, the order of business quickly became sending explorers who would discover and secure a site for a colony while simultaneously raising the funds to sustain

\footnotetext{
${ }^{235}$ Foster, "The Colonization of Free Negroes," 48.

${ }^{236}$ Staudenraus, The African Colonization Movement, 20.

${ }^{237}$ Shick, Behold the Promised Land, 6.

${ }^{238}$ Ibid., 36.

${ }^{239}$ Clay remained a staunch advocate of the ACS and Liberia nonetheless, eventually invoking the rhetoric of a benighted Africa as well (as discussed below).
} 
the transportation and settlement scheme. The first task took the form of three expeditions that took place between 1818-1821, the completion of which established, however tentatively, the colony of Liberia in the location in which it continues as a modern nation today.

The aforementioned Rev. Samuel J. Mills had rushed to the Washington, D.C. meeting that created the ACS, only arriving the night before in time to attend a prayer meeting, an auspicious start from his point of view for a project he perceived as expressly missionary. Mills quickly volunteered his services as primary explorer for the ACS, and upon the group's approval, he recruited "Ebenezer Burgess, the professor of mathematics and natural philosophy at the then infant University of Vermont. Burgess, who prided himself on being a linguist, took for granted that he could serve as interpreter in multilanguage Africa." ${ }^{240}$ And, indicative of such shortsightedness in the American perspective on Africa of the time, Mills encouraged Burgess's thinking and "assured [him] ...that his knowledge of Spanish would be 'eminently useful' to the success of the mission., ${ }^{241}$ In preparation for Mills and Burgess's departure, and having consulted Cuffee already, the ACS committee sought advice from the British who created the model the ACS hoped to copy and so "wrote to William Wilberforce....They asked the 'distinguished philanthropist' Thomas Clarkson for specific information about colonial sites along the African coast." Clarkson's recommendation was that the Americans settle on Sherbro Island, 100 miles down the coast from Sierra Leone. ${ }^{242}$

\footnotetext{
${ }^{240}$ Wilson, Liberia: Black Africa in Microcosm, 14.

${ }^{241}$ Staudenraus, The African Colonization Movement, 41.

${ }^{242}$ Ibid., 37.
} 
By late 1817, the pair had left for England, where they spent a month meeting with several of those involved in Sierra Leone as well as gathering a collection of the books that had documented the Sierra Leone project (which Burgess later summarizes in his account of their trip). Departing in February 1818 for the coast of West Africa, Mills and Burgess spent the weeks en route to Freetown reading through these texts, garnering as much information as possible, much of which they later quoted back to the ACS intermixed with their own findings. After arriving on the continent, they stayed a week in Freetown, where "Mills was less a collector of African data and more a student and admirer of British benevolence. From the moment he reached Sierra Leone he vibrated with missionary zeal." ${ }^{, 243}$ The two hired a local vessel and spent six weeks touring the coastline south of Sierra Leone, including Sherbro and other towns and areas along the way, all the while attempting without success to secure a clear commitment from the people living there to sell them land. As Liebenow and others have stated, the Americans repeated the same mistake of the British in that they "did not appreciate that the concept of 'sale' of land had no meaning in societies where land was distributed communally on the basis of usufructuary right of occupancy rather than individual private freehold,"244 an ignorance that continued to plague them through the establishment of Liberia. ${ }^{245}$

${ }^{243}$ Ibid., 43.

${ }^{244}$ Liebenow, Liberia, 16.

${ }^{245}$ David Kazanjian explains this further: "The ACS appropriated the first of its land in western Africa from indigenous leaders through fee simple treaties that had very different meanings to the two parties: to the ACS representatives, the treaties conferred land as property in exchange for a one-time payment of cash and goods; to the Africans, who did not think of large tracts of land as private property, the treaties simply allowed the Americans to live on the land and to engage in trade ("The Speculative Freedom of Colonial Liberia," 864). 
Nonetheless, they viewed this section of the African coast positively and as having the potential to meet their various intentions (i.e., settlement, Christianization). They set sail for America; however, having left England with signs of consumption months before, two weeks into the return voyage Mills took ill and "died of hiccups on the way home, ${ }^{, 246}$ a death that was subsequently lamented extensively at home to the point that Mills posthumously took on martyr-like proportions. ${ }^{247}$ Despite the loss of his partner, "Burgess arrived in the summer of 1818 ecstatic about Sherbro....With misleading optimism, he assured the Colonization Society"248 of the alignment of Sherbro with their needs and the reception they would receive. Extensive excerpts from Mills' journal were soon published by the Colonization Society in its $2^{\text {nd }}$ Annual Report as well as in Gardiner Spring's Memoir of Samuel John Mills, and Burgess's report to the Society, which included a journal as well as a compilation of source material on Africa, was read to a Society meeting shortly after his return and subsequently published.

Given Burgess's encouraging report, the ACS quickly assembled a second team of explorers whose joint task this time was not only to secure a location for settlers but indeed also to accompany a modest group of them to the location and help establish them there. As a result of negotiations with President Monroe to secure federal funding for the project, the government agreed to hire Samuel Bacon as agent and John Bankson as his assistant; additionally the Society employed Samuel Crozer as agent. With 86 settlers

\footnotetext{
${ }^{246}$ Foster, "The Colonization of Free Negroes," 45.

${ }^{247}$ See in particular Thomas Richard's Samuel J. Mills: Missionary Pathfinder, Pioneer and Promoter for an image of Mills as a martyr to the cause of Christian missionary work in Africa.

${ }^{248}$ Miller, The Search for a Black Nationality, 56.
} 
aboard the Elizabeth, the agents departed New York on 31 January $1820,{ }^{249}$ beginning the first nationalized settlement scheme for free and freed African Americans; Charles Wilson writes that "a local newspaper...The New Yorker, termed the Elizabeth the 'Black Mayflower." 250

The group headed to Campelar at Sherbro, where John Kizell, one of Cuffee's associates, had built a facility to house immigrants; Campelar, however, had no fresh water and was a malarial swamp. ${ }^{251}$ Sherbro, tragically, proved not as hospitable as the agents and settlers had been led to believe, and in short order all three government agents perished. "By the end of September," Wilson continues, "the death list had grown to an appalling forty-nine - more than half the original company of eighty-six.. ${ }^{, 52}$ Daniel Coker, African American missionary and friend of Cuffee, attempted to lead the remnants, who made their way to Fourah Bay at Sierra Leone and awaited ACS assistance. ${ }^{253}$

The loss of Mills quickly paled in comparison to the martyrdom en masse American colonization seemed to require. Shick comments,

To have admitted that the mortality rate made the price of emigration far too high to be continued would have meant the end of the organization. The managers were seemingly unprepared to advise the termination of their project and by extension, their own jobs. Some historians have since considered the effort to have been the work of idealists convinced that their plan was the most humane answer to America's race problem. The mortality rates and the Society's response during the period hardly represent a humane answer to any problem. ${ }^{254}$

\footnotetext{
${ }^{249}$ Staudenraus, The African Colonization Movement, 55, 57-58.

${ }^{250}$ Wilson, Liberia: Black Africa in Microcosm, 19.

${ }^{251}$ Shick, Behold the Promised Land, 22.

${ }^{252}$ Ibid., 22.

${ }^{253}$ Ibid.; also see Staudenraus, The American Colonization Movement, 61.

${ }^{254}$ Shick, “A Quantitative Analysis of Liberian Colonization," 58.
} 
Nonetheless, the loss of the agents was lamented at home such that a sermon preached by William Muhlenberg at St. James Church in Philadelphia in memorial of Bacon and Bankson was itself subsequently published. And Jehudi Ashmun penned and published a memoir of Bacon prior to his own departure as Society agent there. While the fervor of the cause - and thus its missionary bent of the ACS's overall project and its accompanying rhetoric — was only further stirred by these losses, the second expedition had discovered little of Africa and reported even less, with one rather crucial exception: “A young lieutenant named Matthew Perry, who later achieved fame as Commodore of the Africa Squadron" 255 had been "assigned to the war sloop Cyane; his mission: Escort the first group of ACS emigrants to Africa."256 President Monroe, while not having secured federal funding or oversight of the ACS's project, nonetheless as "a supporter of African Colonization" had "ordered naval forces to assist in founding Liberia.",257 And so while escorting the second expedition, Perry sighted Cape Mesurado, recommending it to his superiors upon his return. ${ }^{258}$

In the meantime, with the losses mounting and the risk of the colonization project collapsing altogether, the ACS hastily assembled a third expedition, this time with more agents, fewer colonists, and a mandate to settle wherever they could find a place on the coast that would sustain the health of the settlers. While the government-appointed

\footnotetext{
${ }^{255}$ Liebenow, Liberia, 15.

${ }^{256}$ Van Sickle, “Reluctant Imperialists," 108.

${ }^{257}$ Ibid.

${ }^{258}$ Grand Bassa and neighboring Mesurado were precisely where the third expedition focused its efforts and Mesurado where the colony was finally established, a fact indicated by its close proximity to
} modern-day Monrovia. 
agents included J.B. Winn and his assistant, the Reverend Ephraim Bacon (brother to the preceding agent who had perished just months before), the ACS appointed the Reverend Joseph R. Andrus and his assistant, a very young Christian Wiltberger, ${ }^{259}$ as its agents. This coupled with the fact that two of the settlers, Lott Cary and Colin Teague, were freed blacks who went as missionaries suggested a stronger turn towards a Christianizing focus in the overall project: the sorts of volunteers the project received were increasingly of that mindset, and the government and ACS obligingly appointed such representatives to Africa. As the agents' journals confirm, those who went to at last discover the promised land ${ }^{260}$ recorded their religious activity often as much or more than the details of their travel and discovery. On the expedition that at last found the site that would become Liberia, the encounter with Africa was overwhelmingly perceived and constructed such that faith preempted all other concerns.

On 23 January 1821 the four agents, Mrs. Winn and Mrs. Bacon, and 33 settlers departed Hampton Roads, Virginia on the Brig Nautilus for Sierra Leone. On 8 March 1821, the Nautilus arrived in Freetown with supplies; meanwhile on the voyage, Lott Carey had formed the emigrants into a congregation. The first order of business was to assess the state of the previous settlers, and then to discover a viable settlement site, and to the latter end, Andrus and Bacon left Winn and Wiltberger in charge of the collective group of settlers at Fourah Bay while they explored the coast south of Sierra Leone. Eventually finding Grand Bassa, a polity abutting Mesurado to the south, they negotiated

\footnotetext{
${ }^{259}$ According to his descendants' records, Wiltberger was a 22-year-old church communicant at St. Paul's Philadelphia at the time he left for Africa and was ordained after his return, in 1831. While his journal is one of the largest of the original American explorers in Africa, it remains unpublished and his biography scant at best. That said, his missionary sensibilities are exceptionally ardent in his journal.

${ }^{260}$ To use the words of Tom Shick.
} 
with King Jack Ben and on 12 April 1821 secured approximately 40 square miles of land in exchange for a \$300-a-year tribute to the king. ${ }^{261}$ Meanwhile, however, as Floyd Miller explains, a

lack of a clear understanding as to the relationship between the settlers and the agents again led to bickering and strife. Almost from the moment the Nautilus arrived in Africa, Cary and Teague were unhappy with their ambiguous status, uncertain about their responsibilities to the government and to the Colonization Society, and, finally, disturbed by demands from the agents which they feared would hinder their work as missionaries....Almost two months later the two missionaries accused Andrus, the Society's chief agent, of hoarding provisions for the agents; the following week they again opposed the Colonization Society's authority by refusing to sign the Society's Constitution when Andrus and Wiltberger circulated it among the colonists. ${ }^{262}$

Furthermore, upon hearing of the treaty with King Ben, the ACS rejected it on the basis of the yearly tribute, recalled Andrus as Society agent, and rushed Dr. Eli Ayers to Fourah Bay to replace him. The chaos of the third expedition compounding rapidly, it climaxed when both Andrus and Winn perished of illness (as well as Captain Blair who had captained the Nautilus) and Bacon also fell ill and fled on the next vessel heading west across the Atlantic. ${ }^{263}$

While historians differ on the precise details, Ayers (having arrived in West Africa to find Wiltberger alone with a disorganized group of survivors) met up with Lt. Robert F. Stockton who had been given command of the USS Alligator in support of Ayers. Stockton, nearly as young as Wiltberger at the time, had been a student of Robert Finley in Baskingridge ${ }^{264}$ and shared his sentiments towards colonization. Desperate to

\footnotetext{
${ }^{261}$ Staudenraus, The African Colonization Movement, 62; Shick, Behold the Promised Land, 23.

${ }^{262}$ Miller, The Search for a Black Nationality, 69-70.

${ }^{263}$ Staudenraus, The African Colonization Movement, 62; Shick, Behold the Promised Land, 23.

${ }^{264}$ Staudenraus, The African Colonization Movement, 16.
} 
resolve the situation before more settlers perished or all hope of bringing them together to a settlement site faded, Ayers and Stockton "procured a site 'better adapted to the purpose of colonization than Sherbro' by focusing on the location Perry suggested during the first visit to the coast, Cape Mesurado." ${ }^{265}$ The accounts of Stockton and Ayers' negotiations with King Peter of Mesurado indicate the passing of several days without progress, at which point, on 15 December $1821,{ }^{266}$ Stockton's patience ended: "Most accounts indicate Stockton responded to Peter's resistance to American settlement by aiming his pistol at the king's head, threatening to kill him if he did not sell land to the ACS. $" 267$

While some of the settlers distrusted the ability of the ACS to succeed and chose to stay in Sierra Leone or where they had settled along the way, most followed Ayers to the Cape Mesurado. The glue that held the remnants together had less to do with a philosophy of personal liberation from American slavery and racism than with the missionary work they felt they had come to bring to Africa: "Only the deep sense of mission among the immigrants" writes Shick, "kept the vast majority from abandoning the colony during its initial period of settlement." 268 After a few months of reorganizing, on 25 April 1822, "the first Afro-Americans set foot on Liberian soil," finally

\footnotetext{
${ }^{265}$ Van Sickle, "Reluctant Imperialists," 109; see also Shick, Behold the Promised Land, 23.

${ }^{266}$ Staudenraus, The African Colonization Movement, 65.

${ }^{267}$ Van Sickle, "Reluctant Imperialists," 110; see also Staudenraus, The African Colonization Movement, 65, and Campbell, "Redeeming the Race," 128.

${ }^{268}$ Shick, Behold the Promised Land, 24.
} 
successfully establishing an American colony in West Africa; as a sign of things to come, "The agents organized immediately to occupy the adjacent mainland."269

Almost exactly five years to the day after that first meeting in Washington, D.C., the ACS had established a firm foothold in West Africa, one to which it would send thousands of settlers over the coming decades, of which astoundingly high numbers would, like their predecessors, perish from illness and occasionally conflict with the people among whom they had settled. Their agent-explorers had along the way been some of the first Americans-like the British explorers, such as Smeathman, the Falconbridges, and Park, before them — to go into Africa with the intent of discovering the landscape and people. The body of writing these explorers left behind — some published and distributed, some remaining in manuscript—clarifies that perspective through a rhetoric of Africa and Africans that constructs them primarily as objects of the expression of faith: whatever else the continent and its people might be, they were primarily there to fulfill the agents' and settlers' need to be good Christian evangelists and stewards. The trials and martyrdom experienced during those five years actualized for many of the participants and spectators the Christian ethic of suffering for one's faith, and this in turn confirmed the nature of the colonization enterprise as missionary. As a result, the discovery and colonization of Liberia accompanied (and for many replaced) slavery in American thinking as the discursive entry point for Africa, helping to construct that pervasive new rhetoric of Africa as benighted, fallen, and darkened, a land of spiritual poverty in need of spiritual redemption to be achieved through American missionary work. And while the presence of this lexicon in American writing about

${ }^{269}$ Ibid. 
Africa has already been alluded to earlier in the chapter, it is returned to now for a deeper consideration of how the Liberia experience seems to have informed the rhetorical turn in that writing.

\section{II: The Lexicon of Africa: A Focus on American Writing at the Occasion of Liberia}

The repeated depiction of Africa as benighted or degraded merits further exploration, particularly the proliferation of these terms across the divide of slavery politics. In theory the term benighted could be intended benignly, suggesting one of two historical definitions. The first—“overtaken by the darkness of night"- suggests some negative force inflicted upon the continent, a perspective logically embraced by abolitionists, with the force being the evil of slavery, in particular the act of enslaving one's own. However, the other historical definition - "involved in intellectual or moral darkness," "unenlightened," and "intellectually and morally ignorant"270—seems to suggest a much different locus of agency—Africa itself-that some pro-slavery writers drew upon as justification for why Africans were better off outside of Africa, enslaved in America and the West Indies. Defining Africa therefore not only as a place where bad deeds were done but also as a recipient and victim of such deeds formed an overall view of the continent as a place where things go poorly in general. The fearful mortality rates of British and American colonization efforts seemed only to confirm such a view, and so

${ }^{270}$ The O.E.D.'s etymology dates the term to at least the 1570 s, and its definitions read, " 1 . Overtaken by the darkness of the night; affected by the night 2. Involved in intellectual or moral darkness; Involved in obscurity." Webster's reads, "1. Overtaken by darkness or night 2. existing in a state of intellectual, moral, or social darkness: unenlightened." Dictionary.com reads, "1. intellectually or morally ignorant; unenlightened 2 . overtaken by darkness or night." 
the term benighted and its synonyms began to work for multiple modes of representing

Africa.

To further clarify the extent and nature of this rhetoric in American writing at Liberia's founding and establishment, it will be useful to consider a few further symptomatic texts from writers who did not travel to Africa, prior to considering the writing of those who did. It is important to clarify at the outset that the rhetoric of a benighted Africa endured for perhaps twenty years - beginning with the language of the founders and agents of the ACS and what they hoped to do for Africa through colonization, and winding down by the mid-1830s, after Nat Turner's Rebellion and the failure of Liberia to solve American race problems (among other events) redirected Americans' focus on the problems of race relations from Africa back to the situation within America. ${ }^{271}$

Henry Clay, who spoke ardently in favor of the ACS, was one of the chief architects of the new rhetoric of constructing Africa according to its lack of Christian identity. In his 1827 speech, "On African Colonization," he felt emboldened to say regarding the Society's plans that "every emigrant to Africa is a missionary carrying with him credentials in the holy cause of civilization, religion, and free institutions." ${ }^{272}$ To the extent that every emigrant who left America under the guise of the Society was a missionary, so too Africa must at every moment be a mission, a place open to change and

${ }^{271}$ As will be seen later at the end of this chapter and the beginning of the next, that shift from a focus on Africa to a focus on African Americans in America brought with it an increasingly racialist and dehumanizing rhetoric, different altogether from the rhetoric used during the Liberia colony period (Liberia declares independence and becomes a nation officially in 1847; it had operated as a de facto independent country for some years already, given the U.S. government's isolation of it politically, and the ACS's inability to fund or effectively administrate it from afar).

${ }^{272}$ Clay, Speeches of the Honorable Henry Clay, 582. 
for which change is possible. Employing the so-called "providential" argument that continued to appear on both sides of the slavery debate over the ensuing decades, ${ }^{273}$ Clay summarizes the missionary cause as follows: "Thus to transform an original crime into a signal blessing, to that most unfortunate portion of the globe."274 Arguing that slavery would in the end be seen as salvation not only because it brought some Africans to America to be converted, but also because they could now return and convert the entire continent, Clay's rhetoric continues the image of Africa as unfortunate, as well as mutable. While mutability might seem like an insignificant distinction to focus on, it echoes the notion that benighted or degraded suggests, which is that Africa can change and in fact has changed, a notion resisted by late- $19^{\text {th }}$-century rhetorics about Africa and Africans in which the place and people are depicted as eternally in stasis - it is, once again, that distinction between benighted (darkened), and dark, between whole and degraded.

Expanding on his rhetoric of a binary world of those who have come into light (America) and those who have fallen into darkness (Africa), Clay attacks opponents of African colonization, writing, "They must blow out the moral lights around us, and extinguish that greatest torch of all which America presents to a benighted world, pointing the way to their rights, their liberties, and their happiness." ${ }^{275}$ His choice of the word "moral" echoes the overall Christianization of his rhetoric about Africa, and he was

${ }^{273}$ See American Colonization Society, The Annual Reports of the American Society, "First Annual Report," which argues that African American emigrants might "carry back to the country of their origin the seeds of civilization, which might render their sojournment here a blessing in the end to that country" (6). This is also discussed at length in terms of Samuel Crowther and Martin Delany in the next chapter, under the so-called "providential" interpretation of the Atlantic slave trade.

\footnotetext{
${ }^{274}$ Clay, Speeches of the Honorable Henry Clay, 581.

${ }^{275}$ Ibid., 583.
} 
joined in this moralizing by his detractors, indicating a pervasive sense that this is how one should think and write about the continent at the time, quite a different lens for viewing Africa from the one employed by the founders of Sierra Leone. Much of this has to do with the fact that Africa and Africans were essentially an afterthought: at stake collectively for the ACS, Clay, and their detractors was not what to do about Africa but rather what to do about African Americans and their status in America. Those who would remove them from America constructed their emigration to Africa as the moral act; those who would liberate them in America constructed their freedom there as the moral act. Morality, not pragmatism, became the guiding principle, an utterly different concern from the British colonization of West Africa when pragmatism dictated and morality (in the guise of Christianization) accompanied at best.

Echoing benighted, the term degraded found similar use by various members of the ACS leaders and agents, originally in the first Annual Report published in 1818. The introduction to the Report speaks of being concerned with the "future comfort of an unfortunate class of men with the civilization and happiness of an afflicted, oppressed, and degraded quarter of our globe" and with "placing the situation of their brethren here and in Africa in that scale of happiness and respectability among the nations of the earth from which they have long been degraded..276 Definitions of degraded typically begin with notions of reduced or lowered, and so the word's equally pervasive use and oft proximity to benighted reinforces that concept of Africa's movement from a previously higher state to the currently lower one, a characterization of particular interest to the ACS, since members sought as part of their mission to create further movement, albeit in an

\footnotetext{
${ }^{276}$ American Colonization Society, The Annual Reports of the American Society, "First Annual Report," 2, 5 .
} 
opposite direction. Of particular note, however, is that both terms construct rhetorically an Africa that is in motion and historically capable of change. ${ }^{277}$

William Lloyd Garrison, that champion of abolition, was quick to be one of the great detractors of the Liberian scheme, chiefly because it continued to allow for slavery as well as inequality in America. Yet even in his critique of the ACS's arguments for colonization, he accepts their moralizing terms for characterizing Africa, particularly of an Africa fallen into darkness. In his 1832 "Exposure of the American Colonization Society," he contests their ideas of what should be done about race relations in America, but not their understanding of race itself. Writing, for example, of "those wretches,",278 he discusses "the Africans...a population degraded by slavery, and, to a lamentable extent, destitute of religious and secular knowledge." ${ }^{279}$ The key term here is "degraded," which reiterates the movement from one state of being to another, suggested by that idea of a "benighted" place. Later, paraphrasing the ACS, Garrison writes, "Many a poor native African has been led to embrace the gospel...who else had lived and died a heathen" and calls Africa "a heathenish country."280 Again, by himself invoking terms such as heathen, degraded, and benighted, Garrison is accepting a Christian determinism for discussing Africa—agreeing with that determinism, apparently—and in particular is reiterating that notion of movement, writing of Africa as a place that could

${ }^{277}$ Of particular relevance later in this project when examining the rhetoric of the Dark Continent, which relies on a historically stable or stagnant Africa.

${ }^{278}$ Garrison, Selections from the Writings and Speeches, 20.

${ }^{279}$ Ibid., 24.

${ }^{280}$ Ibid., 20, 24. 
be "redeemed, regenerated, and disenthralled" with "the entire regeneration of Africa" being of utmost importance. ${ }^{281}$

His critique of the ACS's desire "to reclaim and evangelize benighted Africaand various other marvels" has, apparently, not to do with his characterization of Africa as being in a fallen, darkened state, but rather that retrieving it from such is unrealisticthe stuff of marvel. ${ }^{282}$ And again, he deplores their means, essentially the ACS's desire to outsource justice, stating that even if he "were sure that the Society would accomplish the entire regeneration of Africa by its present measures," he would still condemn $\mathrm{it}^{283}$; his agreement with the need for Africa's regeneration is clear. He clarifies this by stating, "Most intensely do I desire to see that ill-fated continent transformed into the abode of civilization," but also when he refers to Africans as "poor, miserable, benighted idolators. ${ }^{284}$ It is important to keep in mind that the point of examining these writers is the revelation that when they employ the term benighted and the rhetoric of Africa in need of salvation, they employ a Christian lens as the chief means with which to view Africa, and that this is a rhetorical shift both in terminology and in focus from the rhetorics of Africa at the founding of Sierra Leone, which constructed Africa according to a variety of British interests but did not privilege Christianity more than others (if they privileged one at all).

So pervasive was the Christianizing lens and its lexicon the rhetoric of Liberia that individuals far more diametrically opposed than Clay and Garrison took it up.

\footnotetext{
${ }^{281}$ Ibid., 24, 20.

${ }^{282}$ Ibid., 17.

${ }^{283}$ Ibid., 20.

${ }^{284}$ Ibid., 23, 20.
} 
Radical African American activist David Walker writes in his Appeal, when excoriating "the enlightened Christians of America" for preventing black literacy, "They are so afraid we will learn to read, and enlighten our dark and benighted minds" ${ }^{285}$ But so too does E.N. Elliott write in the introduction to his equally radical pro-slavery anthology Cotton is King, "Efforts have been and are now being made, to extend the benefits of civilization and religion to the benighted races of the earth. ${ }^{286}$ The arrival of this term benighted is crucial in the history of rhetoric about Africa for two very important reasons: because it signals a shift from the Sierra Leone period to using specific terminology repeatedly to adorn the term Africa itself, something we have seen was not the practice in that period, and because that shift is dominated by religious and moralizing rhetoric, also quite different from the rhetoric of the Sierra Leone era. To modify the meaning of Africa in a way that specifically has to do with darkness — that utterly familiar rhetoric for modern readers - is to predict, even lead to, the next rhetorical turn regarding Africa, when it becomes the Dark Continent.

Before that, however, a close look at the writing of the explorers of the ACS is called for, because they more than any other writers about Africa in the 1810s-1830s invoked and perfected the rhetoric of framing Africa and Africans in the moralizing, Christianizing view of which the term benighted was merely a sign at the wayside.

\footnotetext{
${ }^{285}$ Walker, David Walker's Appeal, 65.

${ }^{286}$ Elliott, "Introduction" to Cotton is King, xv.
} 
III: American Explorers in Africa: American Colonization Society Expeditions, 18181821

An important detail in looking at the rhetoric of Africa during the founding of Liberia is that while it took on a dramatic overtone of religious moralizing and determination, this was not to the exclusion or eradication of the preceding rhetorical moves made in characterizing Africa. Still within the travelers' accounts are to be found what might be thought of as answers to the standard questions expected to be addressed in such narratives, such as details of the landscape, assessments of the fertility of the soil, statements of the temperament of the people, and the potential for trade, all of which might fall under the comparative umbrella of a rhetoric of viability. Siegfried Huigen discusses this rhetoric in his case study of $16^{\text {th }}$-century Dutch explorers in Zimbabwe: it was the

ars apodemica (from the Greek "apodèmeo", "to travel"), the science of travel that had emerged toward the end of the sixteenth century. Among other things, this science of travel insisted upon the notation of observations under a varying number of topical headings, concerning, for instance, geography, place names, politics, customs, and so on and so forth. These observations were subsequently ordered systematically and presented in a travel report. The use of topical questions for the composition of a travelogue derived naturally from the example of the rhetorical inventio (the discovery of subject matter) ${ }^{287}$

Mills and Burgess's specific instructions from the ACS included the following similar guidelines: "We would particularly direct your attention to the climate, soil, and healthiness of the country, and its fitness for agricultural improvements." The directive continued, asking for specific details on mountains, rivers, and "every thing that may be

${ }^{287}$ Huigen, "Travellers to Monomotapa," 214. 
considered interesting and useful to the society." Lastly, it requested they "ascertain the character of the different nations or tribes on the coast.,"288

If the founding of Sierra Leone, then, was accompanied by (and achieved through) rhetorics of Africa that constructed it in terms of its viability for the British interests in settlement of British blacks, commerce, and expansion of British cultural influence, the founding of Liberia too utilized such rhetoric. However, as stated above, this sort of rhetoric was subsumed by the privileged moralizing of an Africa in need of Christianizing. What had been a triad of Christianity, commerce, and civilization during the founding of Sierra Leone was now, during the founding of Liberia, converted to commerce in the service of civilizing Christianity, but "above all," in the words of ACS President Bushrod Washington, "the pure doctrines of the christian [sic] religion.",289 To reiterate from earlier in this chapter, the three expeditions to Africa organized by the ACS between 1818-1821 that accomplished the founding of Liberia resulted in five surviving explorers' accounts representing all three expeditions. They include Burgess's 1818 Address to the American Society for Colonizing the Free People of Color of the United States; extensive excerpts of the journal of Samuel J. Mills, published in the ACS's 1819 Second Annual Report and in slightly different form in Gardiner Spring's 1829 Memoir of Samuel John Mills; brief excerpts from Samuel Bacon's journal in Jehudi Ashmun's 1822 Memoir of the Life and Character of the Rev. Samuel Bacon, A.M.; the 1821 Abstract of a Journal of E. Bacon, Assistant Agent of the United States, to Africa; and the unpublished manuscript of Christian Wiltberger's 1821 diary.

288 American Colonization Society, The Annual Reports of the American Society, "First Annual Report," 12. Report," 3.

${ }^{289}$ American Colonization Society, The Annual Reports of the American Society, "Third Annual 
Additionally, while Stockton did not keep a journal of his time with Ayers, and while we only have letters of Ayers from years after his trip with Stockton, none of which refer to that expedition, we do have Stockton's address in support of colonization from The Proceedings of a Public Meeting of the ACS published in 1829.

In order to set the stage for considering the specific details of these journals, it is worth briefly revisiting Paul Cuffee who immediately preceded the ACS expeditions and who gave counsel to the ACS. Carryover from rhetorics of Sierra Leone can easily be seen in some of his writings about his expeditions there, a continuity the ACS agents themselves maintain to a certain degree. Referring to his first trip to Sierra Leone in 1811, he writes in traditional anthropological detail,

On the $18^{\text {th }}$ of the $3 \mathrm{~d}$ month, I travelled in amongst the natives of Africa. The first tribe I met with was called the Bullone Tribe. Their king, whose name is George, appeared to be very friendly....This tribe, from what I could gather have adopted the mode of circumcission, and seem to acknowledge by words the existence of a Deity.... The Mendingo Tribe professes Mahometanism. I became aquainted with two men of this tribe who were apparently men of considerable learning; indeed this tribe generally, appeared to be a people of some education. Their learning appeared to be the Arabic....They have declined the practice of selling their own tribe; but notwithstanding this, they continue to sell those of other tribes, and thought it hard that the traffic in slaves should be abolished, as they were made poor in consequence thereof. ${ }^{290}$

Cuffee's matter of fact manner of speaking about those he met—King George, the two Mendingo men - and the details of their society is familiar in its similarity to the kind of travel narrative detail provided in Mungo Park, Anna Maria Falconbridge, and others: Cuffee appears like them to relate interesting or unique details of what he encounters, but does so without making grand deductions about Africa or Africans based on them. He resists constructing a grand narrative about Africa, based on his first hand experience.

${ }^{290}$ Qtd. in Hill and Kilson, Apropos of Africa, 17. 
Even when he does turn to speaking of Christianity, he "wish[es] that the inhabitants of the colony might become established in the truth, and thereby be instruments in its promotion amongst our African brethern [sic]. ${ }^{291}$ And typical to outsiders coming to Africa, he exhibits a hint of superiority nonetheless devoid of outright derision (the latter of which we $d o$ encounter in later $19^{\text {th }}$-century writers). At the end of his visit, he gives an "Address" to his "scattered brethren and fellow countrymen at Sierra Leone" in which he instructs them as follows: "I earnestly recommend to you the propriety of assembling yourselves together for the purpose of worshipping the Lord your God." ${ }^{292}$ The condescension of believing himself in the position to offer advice is indicative of his sense of superiority, something that might be unexpected given his own African origins; however, indicative of the rhetorical shift towards the question of Christianity, for Cuffee it is his Christian faith that preempts his racial identity, and thus he indicates he can relate to "fellow countrymen" from a privileged standpoint. ${ }^{293}$

To the extent that this taste of Cuffee's invocation of preceding rhetorics about Africa and Africans reveals that such rhetorics transitioned easily to American travelers and writers, similar repetitions are to be found in the surviving journals of the agents of the ACS and their government counterparts. Many of their depictions of Africans, for example, employ the somewhat condescending and dismissive descriptions familiar from the rhetorics of Sierra Leone. Mills, for example, generalizes about Africans, such as when he suggests, "The natives need not be feared. They are not numerous, have few

\footnotetext{
${ }^{291}$ Ibid., 14.

${ }^{292}$ Ibid., 18.

${ }^{293}$ A move we will see repeated below in the discussion of Samuel Crowther and Martin Delany.
} 
arms, timid in disposition, jealous of each other, and broken up into small, independent, elective governments" or when he observes that "the people are generally idle, superstitious, self-indulgent, and fond of ardent spirits. Polygamy is nearly universal." ${ }^{294}$ Also like his Sierra Leone predecessors he at times writes very specifically of certain individuals, such as his description in Bendou of kings Safah of Chaa and his colleague Somano:

Safah soon made his appearance, marching along between the mud-walled cottages, dressed in a silver-laced coat, a superb three-cornered hat, a mantle around his neck hanging nearly to the ground, blue bafta trowsers, considerably the worse for wear; without stockings or shoes. Safah is large, has a broad African face, and an inquisitive eye. Somano is rather slender, and has a face less striking: both are nearly sixty years of age. ${ }^{295}$

These same sort of familiar combinations of condescending but not condemning descriptions of Africans generally and detailed depictions of specific people appear in the other Liberian explorer accounts as well. Samuel Bacon writes, "I am struck with wonder at the appearance of the native Africans. The sickly and depressed countenance of a Philadelphia coloured man, is not to be seen amongst them. A noble aspect, a dignified mien, a frank and open countenance, the entire demeanor of the wild man!" Later he wanders past "six or seven native villages, and asked for water at as many different huts. I always met with the most friendly reception. The natives manifest much benevolence of feeling." ${ }^{296}$ And later, when he meets King Fara on his exploration south, he claims, "I could not fail to admire the beautiful healthy children in numerous groups, wherever we go," and then writes of the king individually, explaining, that "King Fara

\footnotetext{
${ }^{294}$ Spring, Memoir of Samuel John Mills, 189, 201.

${ }^{295}$ Ibid., 173.

${ }^{296}$ Ashmun, Memoir of Samuel Bacon, 254, 255.
} 
said yesterday, he would come if God pleases; a mode of speech worthy of a Christian," ${ }^{, 297}$ as he does with the headman Tasso, who "was very friendly [and] introduced us to his wife; lamented that he had no palm wine for me, and promised to visit Campelar." ${ }^{298}$ These intimate descriptions specify the broad generalizations these writers at times employ about the Africans they encounter, much as their predecessors did during the Sierra Leone era, thus reiterating that some consistency was in place between rhetorics of Sierra Leone and Liberia.

Those explorers of the third expedition make the same familiar move in reference to Africans. Ephraim Bacon writes, "The people all live in little villages or clusters of cottages in each of which is a Headman, who has a plurality of wives. If a native have but one wife, he is indeed very poor," and so on, but repeats the pattern by writing specifically of King Ben of Grand Bassa, when they were negotiating for settlement land: "The King rose up and spoke to the case in the Bassa language, with great energy; his naked arm presented to view from within his robes, which were made of the country manufactured cloth, something in the form of clerical robes." ${ }^{299}$ This familiar back-andforth of generalizing about Africans and then describing specifically the ones the travelers met personally aligns the ACS agents seamlessly with the likes of Mungo Park.

Similarly, the way the ACS agents report on Africa aligns with the rhetoric of previous explorers, with that ever watchful eye for information that might indicate the viability of that part of Africa for their intentions of settlement, as well as for grosser

\footnotetext{
${ }^{297}$ Ibid., 264; lost on Bacon is the King's use of the customary Muslim preclusion to speaking of the future with certainty.

${ }^{298}$ Ibid., 263.

${ }^{299}$ Bacon, Abstract of a Journal, 28, 23.
} 
geographic details. After the first expedition, Burgess reports thoroughly on questions of agricultural products, domestic crops and stock, and the fertility of the soil, concluding that Africa "south of the great desert" is "a land, stored with the choicest minerals, bearing the richest fruits, and covered with a profuse and luxuriant vegetation, to which the shrubberies and forests of northern latitudes present no analogy." ${ }^{\prime 300}$ His expedition partner Mills echoes and even specifically invokes by name the traditional Edenic representation of Africa, writing at one time of "a noble river [that] flows through a luxuriant country," while at another stating that "we obtain increasing proofs of the fertility of the soil, ${ }^{, 301}$ a recurring (and logical) priority for agrarian societies. He later describes a village near Sherbro Island:

It is a romantic little spot....palm, orange, cocoa-nut, banana, and plantain trees, overshadow the houses. Sugar canes, cotton shrubs, and cassada plants, grown on each side the path [sic] which leads to a few rice fields just behind; then the whole is closely encircled with forest trees and wild vines of the richest foliage. Were it the abode of innocence, it might be esteemed a garden of Eden. ${ }^{302}$

Samuel Bacon two years later echoes the image of abundance, writing of a market full of "bananas, plantains, pine-apples, oranges, limes, guavas, rice, cassada, yams, sweetpotatoes and other productions of the country," and again when further south on the coast, repeats this, writing, "I never saw a country of equal fertility. The most luxuriant growth of cotton trees, currant trees, lime and orange trees, and a variety of timber trees and shrubbery; together with bananas, plantains, cassadas, yams, ground-nuts, sweet- potatoes, and acres covered with pineapple plants, lined our walks for miles." ${ }^{303}$ His brother

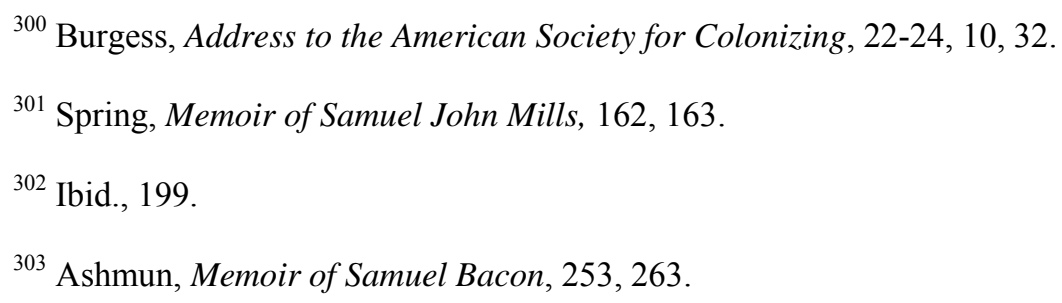


Ephraim repeats this litany of agricultural delights a year later, writing, "The natural growth is luxuriant and abundant... and present every indication of a strong and fertile soil" the products of which include "fowls, fish, oysters, eggs, palm oil and palm wine, cassada, yams, plantains, bananas, limes and pine apples. ${ }^{, 304}$ While it is important to keep in mind that such redundant glorifications of the viability of the African landscape have as much to do with, in Bacon's words, the ACS's promotional effort to "invite her scattered children home, ${ }^{, 305}$ and while it would also seem that the agents carefully read their predecessors' journals, the significance of this is its alignment with the same glorifications of the landscape's viability being promoted during the founding of Sierra Leone.

Having invoked and repeated the rhetorical trends from Sierra Leone, however, the ACS agents depart significantly from those trends and depict Africans disparagingly, condemning their intelligence, their spiritual status, and their maturity. The agents find faults they believe intrinsic to Africans as well as those brought on by slavery, faults which lead to their benighted, degraded state. In the first ACS report, for example, Burgess speaks of having gone "among a people sunk in ignorance and barbarism." Whether he means by "sunk" that they have been there always or that they were brought to such a low state is clarified by his following statement: "A people, who have been scattered and peeled, meted out and trodden under foot,' with cold indifference, by nations of more power, intelligence, and civilization than themselves." ${ }^{\text {306 }} \mathrm{He}$ argues here

\footnotetext{
${ }^{304}$ Bacon, Abstract of a Journal, 14, 16.

${ }^{305}$ Ashmun, Memoir of Samuel Bacon, 270.

${ }^{306}$ Burgess, Address to the American Society for Colonizing, 5 .
} 
that both are true - that the degraded state of Africans was a factor both of their lower "intelligence, and civilization" and having been "trodden under foot" by slavery. His condemnation of the Africans, however, goes beyond merely categorizing them as inferior, as such a critique would lend itself merely to pity or disdain. Burgess clarifies precisely what he means by "ignorance and barbarism"-what exactly that "degraded state" is to which slavery has reduced them—when he writes, "these poor pagans," "the less instructed pagans," and "the more artless pagans" and thereby introduces a theme that is oft repeated by the explorers: the satanic nature of Africans. ${ }^{307}$ For as he explains later, "Their homage is paid to devils"308; and his partner Mills echoes the theme, writing of "the altars on these mountains, which the natives had dedicated to devils.","09

Mills further details the Africans' satanic geography, writing, "Near the Palaverhouse was a little thatched hut, not larger than a spread umbrella, called the witch or devil's house....I passed by the devil's bush, a thicket of shrubs and vines" ${ }^{\prime 310}$ and suggesting that these are not mere place names, but rather information regarding contemporary practice. He describes a scene there and determines it is some sort of satanic ceremony:

The dance begins. Near the town is a thick grove, called the devil's bush, from which they profess to believe the devil makes his appearance occasionally in the evening, during the dance. His approach is known by frightful noises, now resembling the whistling of an elephant, and now the roaring of a lion. The poor

\footnotetext{
${ }^{307}$ Ibid., 11, 12, 20.

${ }^{308}$ Ibid., 30 .

${ }^{309}$ Spring, Memoir of Samuel John Mills, 164.

${ }^{310}$ Ibid., 176.
} 
women and children are obliged to scamper into their houses, and keep clapping their hands, until the devil is gone. Then the dance is renewed. ${ }^{311}$

And Ephraim Bacon echoes the same assessment, in this case writing of the people of Grand Bassa, next door to where Monrovia would soon be established. Bacon writes that the Africans

are in a dreadful state of heathenish darkness; they worship the "Dibbly man" and dedicate daily a part of their food to his Satannic Majesty. They profess to believe that there is a good and merciful Deity, who can and will do them good, and not evil: but that the Devil is all powerful, and that it is necessary to appease his wrath. Every town has its peculiar Devil. ${ }^{312}$

Bacon concludes, "These people are indeed in gross darkness, depending upon their gregres and Devil worship."313 He explains that "all the people wear gregres or charms," items "they never fail to wear when exposed to danger," and laments, "Oh Lord when shall these superstitions cease."314

This latter sentiment is to be found in Burgess as well, who writes of "their superstitions dark and gloomy" and also Mills, who discusses "the superstitious customs of the people" and their vicious customs" 315 with greater precision. Writing of James Tucker on the Boom River near Sherbro, Mills cautions that "he is very superstitious. Some of his people are often accused of witchcraft, or turning themselves into leopards or

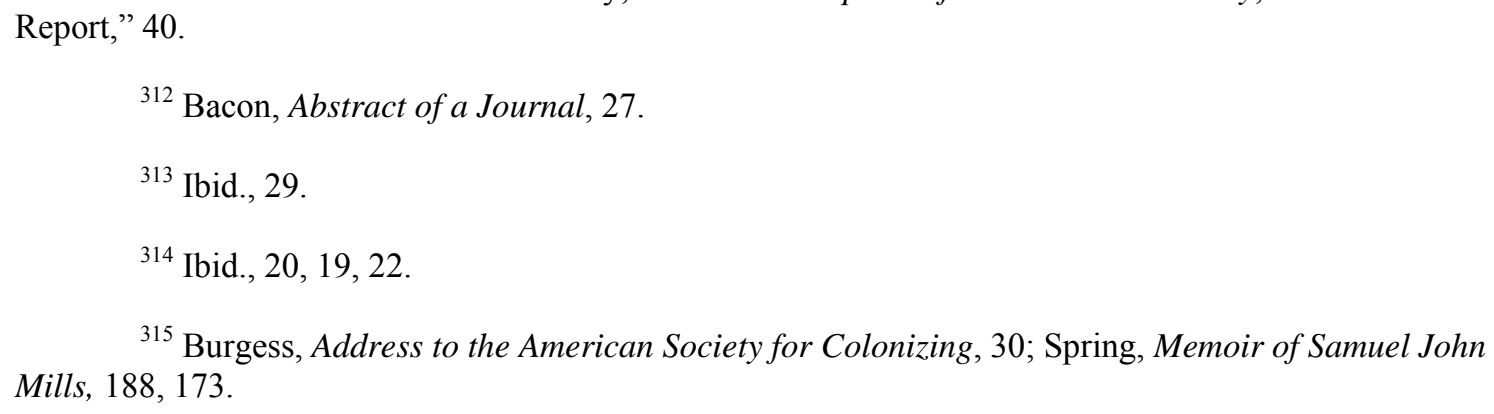

${ }^{312}$ Bacon, Abstract of a Journal, 27.

${ }^{313}$ Ibid., 29.

${ }^{314}$ Ibid., 20, 19, 22.

${ }^{315}$ Burgess, Address to the American Society for Colonizing, 30; Spring, Memoir of Samuel John Mills, 188, 173.

${ }^{311}$ American Colonization Society, The Annual Reports of the American Society, "Second Annual 
alligators, to catch the people."316 Later he offers another example, writing of "the natives who have a particular veneration for serpents, (believing them to be the abode of the evil spirits, whose power and displeasure they deprecate)." ${ }^{317}$ Lt. Robert Stockton, in his address to the ACS years after returning from his naval assignment in which he secured Cape Mesurado at gunpoint, summarizes the other agents' sentiments by speaking of Africa, "where now reigns the blasphemous worship of the Pagan Gods."318 Such a holistic conclusion is common among the agents - and while it was common among most travelers to Africa at that time to generalize about the continent, this conclusion is new in its content and tone and in its unique lexicon. For that benighted, degraded Africa of the proponents and detractors of colonization in America appears in the agents" writings as well. Mills writes of "this dark world" and that "darkness, gross darkness, covers the nations around us."319 Ephraim Bacon writes of "the degraded state of that section of the earth" and twice refers to Africa as "that injured country." ${ }^{320}$ And Robert Stockton calls attention to the "millions who are now in darkness and despair."321

A recurring theme evolving from this state of the continent is that its people have been reduced, which is different from the typical inferiority attributed to Africans by outsiders. Rather the implication is that the darkness and degradation brought on by

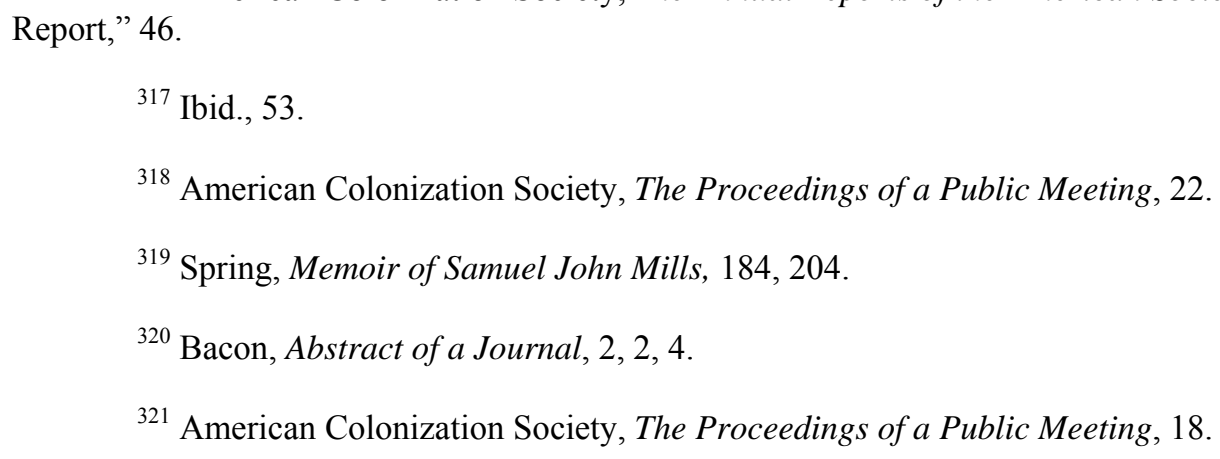


slavery has halted the development of Africans themselves. They are, according to Burgess, "children of nature"; Mills adds, "These people are only children of a larger growth," the latter referring to slavery, that cause of their degradation. ${ }^{322}$ Ephraim Bacon writes of "the degraded children of Africa" and claims that "it indeed requires much patience to deal with these children of the forest. ${ }^{, 323}$ This naturalization and infantilizing of Africans suggests that the darkness and degradation of slavery has somehow pushed Africans back developmentally as individuals and as a society into a pre-civilization past; and while the agents neglect to delve into this notion further, it does establish the precedent for constructing Africa as retrograde in the future, should the ACS fail to reverse the degradation. ${ }^{324}$

This is the rhetoric of the fallen - the benighted state brought on by the enslavement of one's own - a matter on which the agents are even clearer than the founders of the ACS. Burgess refers, for example, to "those parts of the picture of his providence which are now darkly shaded," and elaborates on the "the evil which they have suffered, ${ }^{, 325}$ writing that slave traders

have carried with them ardent spirits to excite the appetite and intoxicate the brain. They have introduced firearms and gunpowder. While the minds of the natives were infuriated to madness, and the instruments of death were in their hands, they have been hurried on to seize each other and sell them to the white men....These three centuries past, no trade to Africa in gold, ivory, ebony, die-woods, ship-

\footnotetext{
Mills, 173.

${ }^{322}$ Burgess, Address to the American Society for Colonizing, 30; Spring, Memoir of Samuel John

${ }^{323}$ Bacon, Abstract of a Journal, 5, 23.

${ }^{324}$ The overall sense of the failure of the Liberian experiment over the subsequent decades might have been seen to support such a deduction, perhaps leading to the rhetoric of the Dark Continent itself.

${ }^{325}$ Burgess, Address to the American Society for Colonizing, 6.
} 
timber, gums, and wax has been so regularly or extensively prosecuted, as that in the lives and bodies of men. ${ }^{326}$

Here Burgess explains that this is a recent fall, rather than a perpetual state of being for Africans: Africa is not always dark, but has darkened "these three centuries past." Such cultural movement means that Africans "have actually forgotten much of their knowledge in the manufactures and the arts which they formerly possessed,",327 which is an enormously significant statement of the recent nature of the fall, given that Burgess recognizes here that they did in fact possess such knowledge previously. Mills echoes this when he writes, "If the slave-trade, that mother of abominations and source of woes unutterable, can be annihilated, Africa will revive and assume a respectable rank among the nations of the earth." ${ }^{328}$ Key to this phrasing is the word "revive," again revealing that these ACS agents believed in an Africa in the past that was both "nation" and one able to "rank" with others; regardless of whether or not Africa surpassed European nations or America on that scale, according to the rhetoric about Africa at this time, it had at least been on the scale of comparison. This will be crucial when analyzing future rhetorics of Africa from the latter part of the $19^{\text {th }}$ century in which the continent is depicted precisely in the opposite way, as never having been capable of much of anything that would compare with the "nations of the earth." For the ACS, this view of Africa meant that their work had a chance for success, whereas later $19^{\text {th }}$-century views of Africans and Africa did not share such optimism.

\footnotetext{
${ }^{326}$ Ibid., 10.

${ }^{327}$ Ibid., 11.

${ }^{328}$ Spring, Memoir of Samuel John Mills, 163.
} 
Mills further laments what once was, writing in this case about the Deong River area and its benighted character visible in the fallen ruins and decay: "This country has seen better days. Its population was once much greater. The ravages of war and the slave-trade are no where more visible than in this river. Towns have been burnt, hamlets are deserted.",329 "These relics of villages,"330 as Mills calls them, vacated utterly by the slave trade, were viewed by Mungo Park, Smeathman, and many others connected with Sierra Leone, when they spoke of rows of houses emptied and ready for the taking. Somehow, the cause of their emptiness eluded the British, whereas Mills and his compatriots recognize it, as Stockton explains: "That part of the country which, 'in Africa's better days,' was covered with numerous villages, but now desolate and untilled, and almost depopulated by the slave trade., 331

And again, what has degraded Africans specifically is not having their fellow citizens removed from the continent, but their selling of each other. The rhetorical juggling required to allow those who have been most active in perpetrating the Atlantic Slave Trade on Africa's west coast $\mathrm{t}^{332}$ - the Americans - to return now as the saviors and redeemers from it is, in the end, simple: the Africans have brought about their own degradation because they, in the words of Stockton, "have been led from the cultivation of their rich and luxuriant soil, and even from the chase, the legitimate pursuit and manly

${ }^{329}$ Ibid., 203.

${ }^{330}$ Ibid.

331 American Colonization Society, The Proceedings of a Public Meeting, 19.

332 Americans argued that the British initiated this trade in the U.S., as indeed they did. And the British, Spanish, and Portuguese were at least as active on the continent, some more so. However, as many local African leaders who met the ACS agents revealed, they distrusted ACS emissaries because the Americans they were accustomed to encountering were typically slave traders. 
employment of savage life, to the unnatural practice of speculating in each other's blood. ${ }^{, 333}$ Burgess echoes this, writing of how the Africans "have been hurried on to seize each other and sell them to the white men., ${ }^{, 34}$ Whatever hand Americans may have had in leading Africans astray can be brushed aside because it is the Americans who now will "induce them to relinquish it and turn their attention towards their own improvement. ${ }^{\prime 335}$ And thus is the constant reiteration of the attempt by the ACS agents in their negotiations with leaders of African polities to get them to give up the slave trade. $^{336}$

"I was fully confirmed in the opinion," writes Ephraim Bacon, "that Africa presented an ample field for the exercises of benevolence, and that the Christian world owed her a debt of gratitude." ${ }^{, 337}$ For what Africa becomes in this rhetorical framework, as has been stated earlier, is terrain in which to pursue Christian endeavor. The "debt" the Christian world owes Africa, according to Bacon, is that Christians now have somewhere in which to practice what they preach: it "would be in as good a cause as we could desire." ${ }^{338}$ His brother Samuel Bacon proclaims, "Oh, what a field for evangelical labour amongst them!"’399 The strongest rhetorical move that could be made towards Liberia in the early- $19^{\text {th }}$ century was that it needed to be Christianized - such a move

${ }^{333}$ American Colonization Society, The Proceedings of a Public Meeting, 19.

${ }^{334}$ Burgess, Address to the American Society for Colonizing, 10.

${ }^{335}$ American Colonization Society, The Proceedings of a Public Meeting, 19.

${ }^{336}$ An irony not lost on those leaders who are reported often to have viewed the Americans with suspicion, since it was most often Americans who they encountered practicing the trade.

${ }^{337}$ Bacon, Abstract of a Journal, 46; or Christian Wiltberger's Diary, 39.

${ }^{338}$ Ibid.

${ }^{339}$ Ashmun, Memoir of Samuel Bacon, 253-54. 
justifies American colonization there and washes away moral qualms about a second relocation of African Americans. Above all this required the casting of Africa as a place fallen into darkness that needed retrieval.

That labor became a rallying cry, and the work to be done was eminently clear.

Samuel Mills establishes this early on, writing that the

altars on these mountains, which the natives had dedicated to devils, are falling before the temples of the living God, like the image of Dagon before the ark. The time is coming when the dwellers in these vales and on these mountains will sing hosannas to the son of David. Distant tribes will learn their song. "Ethiopia shall stretch forth the hand unto God, and worship.",340

Almost every agent and many members of the ACS cite Psalm 68:31, ${ }^{341}$ using Ethiopia as a proxy for Africa, much as was done in biblical times and perhaps in some recognitionto the extent individuals were aware of it—of Ethiopia's ancient Christian heritage. As a unifying epigraph, the psalm cast the work as holy and reiterated Africa as the place holy work was to be done. Mills speaks of bringing "into this country some good men, who will shine as lights in this dark world, ${ }^{342}$ and such a man Samuel Bacon intends to be, proclaiming, "Duty had called me here: God was with me; and I was happy.",343

Ephraim Bacon writes of his intent to "meliorate the conditions of the African race; and propagate the glorious Gospel of God in a heathen land," 344 as Robert Stockton seeks "to civilize this degraded people." 345

\footnotetext{
${ }^{340}$ Spring, Memoir of Samuel John Mills, 164.

${ }^{341}$ See, for example, Bacon, Abstract of a Journal, 2.

${ }^{342}$ Ibid., 184.

${ }^{343}$ Ashmun, Memoir of Samuel Bacon, 246.

${ }^{344}$ Bacon, Abstract of a Journal, 6.

${ }^{345}$ American Colonization Society, The Proceedings of a Public Meeting, 16.
} 
By the time 22-year-old Christian Wiltberger sets sail on the final expedition to find and establish the permanent site that would become Liberia, this rhetoric of Africa is so firmly in place that Wiltberger writes of little in his journal other than the daily "prayer on deck, ${ }^{346}$ discussion of who preached that morning and what verse was explored, ${ }^{347}$ the meetings, sermons, "secret prayer" sessions, and spiritual contemplation he and his companions undertake. Any description of Africa or Africans goes almost entirely without mention, other than as subjects for conversion. Rather the spiritual endeavor of being a good, prayerful, contemplative Christian and encouraging others to do the same consumes the bulk of his text. For example, in his rare mention of Africans, he simply refers to them as "heathen children" or "poor heathens," and "that if the Spirit of God did not change their hearts they would all go to $\underline{\text { Hell., }}{ }^{348}$ Far more often he is caught up in his and his peers' spiritual well being, such as in his letter to his sister, where he states, "It is my earnest desire that you should be a Sunday School teacher." ${ }^{349}$ Considered in isolation, such rhetoric of Africa and Africans where what matters is exclusively whether or not they are coming to prayer might be disregarded due to Wiltberger's youth, his spiritual path (keeping in mind that he was ordained seven years after his return to the U.S.), or his personal religious zeal. Considered in light of his colleagues, however, the rhetorical view of Africa that Wiltberger represents—-where Christianity trumps all else-is a culmination, not an aberration. That he was the last ACS agent standing at the

${ }^{346}$ Wiltberger, Diary, 22. This particular prayer meeting on board the Nautilus, incidentally, took place the evening of their arrival in Freetown.

${ }^{347}$ See for example Wiltberger, Diary, 20 (this while still en route across the Atlantic), 23, 26, etc.

${ }^{348}$ Ibid., 29, 31, 40.

${ }^{349}$ Ibid., 32. 
arrival of Ayers and Stockton and their seizure of Mesurado is a stark reminder of how they envisioned Africa, in terms of who should be entrusted with American ambassadorial duties, so to speak: Christianization, at all costs, and by whatever means necessary. That Cary and Teague, as well as Cuffee, joined in this rhetorical construction of Africa and participated in its realization indicates further the extent to which faith trumped all else, including — as their cases reveal, and as will be discussed extensively in the next chapter-race.

In conclusion, the rhetorical turn in the construction of Africa and Africans by American travel writers, their sponsors, and audiences during the founding of Liberia marked a stark shift from the immediately preceding rhetorics of the same at the founding of Sierra Leone. The continuity between the two, and the particular way the rhetoric of Liberia emerged from that of Sierra Leone is not merely of historical interest. Instead it is utterly suggestive of the source of the long-standing and more popularly known rhetoric of the Dark Continent, which lives on today. The problem, as will be seen later in the rhetorics of the latter part of the $19^{\text {th }}$ century, is the way in which the depiction of Liberia lent itself to appropriation. If a rhetorically providential notion of the fall and its lexicon can be removed, glossed over, or better yet replaced by Darwinian theories about missing links between species, and if spiritual desires can be either found to fail or subsumed by other, greater interests, Africa can be constructed as the land of darkness, or better yet, the Dark Continent.

I want to take a moment to return to the notion of rhetorical imperialism and what the rhetoric of Liberia adds to considerations of it begun with the rhetoric of Sierra Leone. To the extent that rhetorical imperialism is, as Scott Lyons states, to "assert control of 
others by setting the terms of debate, ${ }^{, 350}$ the rhetoric of Sierra Leone goes some distance towards such imperialism. That particular rhetoric is certainly an attempt at asserting control over Africa with the broader intent of bringing Africa into submission; however, the inconsistency of the terms of that rhetoric is such that at best it can only be loosely thematically categorized, as Chapter I demonstrates. While it seems apparent that rhetoric is being leveraged in an imperial fashion in the Sierra Leone endeavor-attempts to limit all definitions and representations of Africans or Africa to how they mattered for British goals and plans - the rhetoric itself comes across as somewhat scattershot when compared with the specific, consistent rhetoric of Liberia.

Lyons writes that the terms referred to above "are often definitional— that is, they identify the parties discussed by describing them in certain ways, ${ }^{, 351}$ and his terms "definitional" and "certain" imply a fixity seemingly missing in rhetorics of Sierra Leone but resoundingly present in Liberia. If, as Lyons continues, "He who sets the terms sets the limits, ${ }^{352}$ it seems the rhetoric of Liberia is much more limiting of Africa and Africans, placing them in a very tight rhetorical box. While arguably rhetorics of both Sierra Leone and Liberia are on the continuum of the imperialism Lyons describes, those of Liberia seem more potent due to their overt nature and more limiting of attempts Africans might make towards rhetorical sovereignty; yet the question remains of the extent to which the specificity matters, if control of representing someone rhetorically has been seized from them to any extent.

\footnotetext{
${ }^{350}$ Lyons, "Rhetorical Sovereignty," 452.

${ }^{351}$ Ibid.

${ }^{352}$ Ibid.
} 
The most extreme version of rhetorical imperialism explored in this dissertation appears in the final chapter; it too is on a continuum of the rhetorics of Sierra Leone and Liberia. However, first is a consideration given to the story of two African descendants coming to Africa as explorers; their journals serve as complicated case studies that reveal the extent to which rhetorical imperialism can be contested, and the limits of rhetorical sovereignty in the specter of that imperialism. 


\section{CHAPTER III: DIASPORANT RHETORICAL CONSTRUCTIONS: THE LIMITS OF RHETORICAL SOVEREIGNTY IN THE TRAVEL WRITINGS OF SAMUEL CROWTHER AND MARTIN DELANY}

The sheer quantity of English language writings about Africa in the era of exploration and discovery signified the heights of fashion to which such narratives had risen amongst the readership of Great Britain and the United States; however, as such they were writings by those whose status as outsiders to Africa was clear and explicit. Black writers - at times participants in the white ${ }^{353}$ movement to Africa, at others in contradistinction to it—also undertook journeys of exploration and discovery to Africa, the journals of which create a new thread in African travel writing. These writers were at once African and outsider: not precisely the subaltern of Homi Bhabha, in that they were not the colonized in the colony, but rather the colonized as the colonizer. ${ }^{354}$

Samuel Ajayi Crowther and Martin Delany made journeys of exploration and discovery to Africa in the middle of the $19^{\text {th }}$ century. And as black writers, their journals

\footnotetext{
${ }^{353}$ It becomes at this point difficult to use terms such as European or American as terms of distinction from African; they are as imprecise as "white" proves to be. The focuses of this chapterMartin Delany and Samuel Crowther - are at once American and European respectively, while African (or black) in origin racially and ideologically; yet they distance themselves from Africans. They are transnationally non-African and non-European/American. To categorize them black writers is as inadequate as naming the tradition they come from white writing. Paul Gilroy writes, "This makes blackness a matter of politics rather than a common cultural condition," a poignant reframing of but not solution to the paradox (qtd. in Crane, "The Lexicon of Rights," 531).

${ }^{354}$ See, for example, George's discussion of this dual identity in terms of Crowther: "One level of the agency of the non-Western subject can be located in the sense in which she participates in and yet reconfigures Eurocentric modes of seeing" ("The Native Missionary,"17).
} 
reflect striking parallels with white travel writing of Africa of the same time, as Andrew Walls puts it, repeating the "conviction of the essential concomitance of Christianity, commerce, and civilisation" as the triad of African need. ${ }^{355}$ Yet they also make distinct rhetorical moves unavailable to their British and American counterparts, displaying at times a greater willingness to engage African communities and individuals in detail (and occasionally with empathy) than their white counterparts. Their experiences and writings therefore can serve as unique case studies for examining Scott Lyons's theory of rhetorical sovereignty, particularly the extent to which his model has historically been achieved by two prominent authors whose experiences came directly as subjects to rhetorical imperialism described in the preceding chapters on Sierra Leone and Liberia. To the extent those chapters establish the specific nuances of late- $18^{\text {th }}$ - and early- $19^{\text {th }}$ century rhetorics of Africa and their imperial nature, the two case studies of this chapter demonstrate the extent to which writers who were subjects of those rhetorics were able to resist such imperialism and reclaim rhetorical sovereignty. Their mutual repetition of the rhetorics in which they were situated indicates the limits of their rhetorical sovereignty. Their moments of resistance (to different degrees) once further into their journeys and farther away from the coast, show to a limited extent cracks in the imperial rhetoric as well as its tenuous nature, suggesting Lyons's theory has at least some historical precedent in Africa.

Crowther's story is unique in that his expedition to the Niger Valley in 1841 was as an African, one who had been enslaved twenty years before but then freed and brought to Sierra Leone, where he converted to Christianity, English language, and British

\footnotetext{
${ }^{355}$ Walls, "Black Europeans, White Africans," 343. Also see Walls, "The Legacy of Samuel Ajayi Crowther," 16; and Campbell, "Redeeming the Race," 127.
} 
culture. ${ }^{356}$ The 1841 Niger Valley Expedition was therefore both homecoming and utterly exploratory, and Crowther wrote about Africa on the expedition simultaneously as objective outsider and returning diasporant. As Olakunle George explains, "Discursively, the unprecedented social location of Crowther and his late nineteenth-century cohort of Christianized Africans compels them to perpetuate racialist and colonialist ideology while also re-configuring it.",357

Martin Delany on the other hand came to Africa after a lifetime in the United States, having spent much of his adulthood advocating black emigration to locations other than Africa. As an African American, his ethos was utterly different from the white ACS agents who traveled to Africa in search of a site for black Americans to be settled. Delany's journey was of a complete and admitted outsider, while simultaneously a selfacknowledged journey to his racial and at least partially ideological roots. The Niger Valley upon his arrival in 1859 was no less foreign to him than the Grain Coast was to Christian Wiltberger. However, Delany's investment was different in that he approached Africa as the objective outsider desiring to be the insider.

Crowther and Delany can collectively be considered and analyzed for their response to and critique of British and American writings about Africa—or simply as challenges to their hegemony. Their actual intersection in Abeokuta, where Crowther and his family served as primary host to Delany for an extended period, highlights the relevance of considering them together, as does the distance which Crowther and Delany both situate themselves from Africa and Africans. Africa remained in Crowther's and

${ }^{356}$ As Northrup writes, "A person such as Samuel Ajayi Crowther underwent a profound transformation in his religious beliefs, wrote and spoke English, and in his devotion to the English people sometimes followed the missionary practice of referring to England as "home"" ("Becoming African," 16).

357 George, “The 'Native' Missionary,” 18. 
Delany's writings generalized and universalized, and Africans were similarly constructed as that somewhat inferior Other in need of rescue. For Crowther, this changes the closer he gets to his home region of Yoruba, at which point he begins instead to describe those around him with specific names, society as being recognizably civilized, and Africa through clear political distinctions and relations. For Delany, the Africa he imagines and describes before his departure remains largely the same while underway — an Africa suitable for receiving his emigrationist agenda, ${ }^{358}$ which is to say a place and people singularly in need - this in spite of his eloquently detailed and specific descriptions of the Yoruba region. To the extent Crowther and Delany both contest the rhetorical conventions of Sierra Leone and Liberia, respectively, they both far more overwhelmingly invoke, reiterate, and represent them. That contesting those conventions was neither the explicit goal of their expeditions nor their writing suggests how resistance to rhetorical imperialism — flashes of rhetorical sovereignty — might appear organically.

The purpose of considering the seminal black travel writing about Africa that Crowther and Delany produced is therefore not simply to examine black writers' rhetoric of Africa and Africans as a counterpoint to that of white writers, but rather to explore the extent to which race in the $19^{\text {th }}$ century is a limiting factor on such rhetoric. The results of this analysis suggest that their efforts to rehabilitate notions of blackness- -through exemplary piety, evangelism, and scholarship on the part of Crowther and radical political activism, professionalism, and publishing on the part of Delany—are subsumed by their parallel argument that Christian faith (accompanied by the accoutrements of

${ }^{358}$ An agenda halted only by the onset of the Civil War, which shifted focus and agenda for Delany as well as many African American leaders, both integrationist and emigrationist, as it suggested a real chance for African Americans to have an equal footing in the United States and thus justified their effort. See Kahn, "The Political Ideology of Martin Delany," 437-38, or Kass, "Dr. Thomas Hodgkin, Dr. Martin Delany," 390, or Kass and Kass, "Doctors Afield," 684. 
overall civilization), in the final analysis, trumps race. That this very argument came out of the colonizing experiences of the early $19^{\text {th }}$ century in Sierra Leone and Liberia strongly indicates in the final analysis the limits of how far race would carry one away from the dominant rhetorics of Africa and Africans of the time.

This chapter is split into a section on Samuel Crowther and a separate one on Martin Delany, after which the question of rhetorical sovereignty is revisited. Because the history of each writer situates them uniquely in relationship to Africa and rhetorics about it, each section in this chapter begins with a preface delineating relevant events from their biographies, information necessary for the theoretical analysis concluding the chapter.

\section{I: Samuel Crowther's Transnational African Experience}

Bishop Samuel Ajayi Crowther was a Nigerian slave turned Sierra Leonean recaptive, turned missionary to Nigeria. ${ }^{359}$ As the first Anglican Bishop of Nigeria, less consideration has been given to Crowther as an author, ${ }^{360}$ yet his Journal of the 1841 Expedition up the Niger River is unique in that his text was written as both outsider and insider to the continent, simultaneously invoking and resisting European rhetorical trends of the time. As the arrival of an extensive contemporary African literature has largely addressed questions and concerns of contemporary rhetorical sovereignty, Crowther's much earlier text challenges European and American claims of African inferiority or

${ }^{359}$ For biographical work on Crowther, see Murphy, "Obstacles in the Way of Love," 49; Lovejoy, "The Children of Slavery," 209; or Walls, "The Legacy of Samuel Ajayi Crowther," 15-16.

${ }^{360}$ See Adeeko, "Writing Africa," 2. 
incapability at the very moment such claims were being cemented. ${ }^{361}$ The first part of this chapter section on Crowther delineates the complicated background of the identity with which he set sail for the Niger Valley in 1841 and from which he viewed and subsequently represented Africa and Africans rhetorically.

The story of Samuel Crowther begins with the "birth of a boy called Ajayi in the town of Ośogun in Yorubaland in what is now Western Nigeria, in or about the year 1807." 362 The time between Crowther's birth and when he was enslaved is documented only to a limited extent, predominantly in his own account consisting of his letter "to the Rev. William Jowett, in 1837, then Secretary of the Church Missionary Society, Detailing the Circumstances Connected with his being Sold as a Slave," more commonly referred to as "Samuel Crowther's Narrative."”363

Crowther begins by detailing his capture, mostly contrasting its horrors with idyllic sentiments of life before, in the "place of my birth, the play-ground of my childhood": "I was in my native country," he explains, "enjoying the comforts of father and mother, and the affectionate love of brothers and sisters." ${ }^{364}$ Crowther then writes the oft-critiqued ${ }^{365}$ lines of how retrospectively he views being enslaved as a blessing:

${ }^{361}$ See Adeeko, who explains Crowther and other early African writers' exclusion from the canon of African Literature and argues why they ought to be reconsidered, given the extent of their resistance to European and American discourse about Africa ("Writing Africa," 2).

${ }^{362}$ Walls, "The Legacy of Samuel Ajayi Crowther," 15.

363 Schön and Crowther, Journals, 371.

${ }^{364}$ Ibid., 374, 372.

${ }^{365}$ For example, see Adeeko: "Slavery's violence is rhetorically equated to the passion necessary for salvation" ("Writing Africa," 20); or Murphy: "Crowther considers his abduction from African an ordeal as well as a deliverance, because in his mind it was the work of God that allowed him this painful but unique opportunity to experience salvation through this unhappy separation from his family" ("Obstacles in the Way of Love," 49). 
From this period, I must date the unhappy_-but which I am now taught, in other respects, to call blessed day, which I shall never forget in my life. I call it unhappy day, because it was the day in which I was violently turned out of my father's house, and separated from my relations; and in which I was made to experience what is called to be in slavery:- - with regard to its being called blessed, it being the day which Providence had marked out for me to act out on my journey from the land of heathenism, superstition, and vice, to a place where His Gospel is preached. ${ }^{366}$

These remarks dually situate Crowther's childhood in the 50-year-long Yoruba wars and the development of Sierra Leone. For it was precisely the decline of the Oyo government and resulting overall instability of the Yoruba region accompanied by the rise of the Fulani slavers that precipitated the sort of raids that took Crowther and his family. ${ }^{367}$ Furthermore, by the time he was purchased by Portuguese slavers, he had "changed hands six times"368 among the Fulani raiders and those who at last sought to export him from the continent.

Crowther's "unhappy day" was nonetheless utterly common at the time, a market glut that both drew the international slave trade to the Bight of Benin ${ }^{369}$ and the attention of British naval pickets patrolling the Atlantic coastline for just such outlawed activity. And when on 7 April 1822 the Portuguese slavers who had purchased Crowther encountered 'His Majesty’s ships 'Myrmidon,' Captain H.J. Leeke, and 'Iphigenia,'

${ }^{366}$ Schön and Crowther, Journals, 372.

${ }^{367}$ Murphy describes how Crowther's “village of Osogun was unexpectedly attacked by Fulani raiders from the North. Unprepared for the onslaught, women and children fled into the bush while the few men who were not in the fields attempted to protect the village and their families with whatever weapons they could lay their hands on. Those who attempted to escape were swiftly followed by Fulani horsemen, who threw lassoes over their heads and herded them as if they were animals" ("Obstacles in the Way of Love," 49).

\footnotetext{
${ }^{368}$ Walls, "The Legacy of Samuel Ajayi Crowther," 15.

${ }^{369}$ See especially Campbell, "Redeeming the Race," 136-137.
} 
Captain Sir Robert Mends," ${ }^{, 370}$ Crowther's rescue by the British initiated the transition from his conception of loss to the aforementioned proclamation of blessing, something completed by his later upbringing and early adulthood in Sierra Leone. ${ }^{371}$

"About six months after my arrival at Sierra Leone," he writes, "I was able to read the New Testament"; he continues, "Being convinced that I was a sinner, and desired to obtain pardon through Jesus Christ, I was baptized on the $11^{\text {th }}$ of December, 1825."372 Baptism and its accompanying blessing were signposts of British acculturation, for he was "baptized by the Reverend John Raban, of the (Anglican) Church Missionary Society, taking the name Samuel Crowther, after a member of that society’s home committee."373

This transition from heathen to Christian, Yoruban to British, was extended when the Church Missionary Society (CMS) started Fourah Bay College in 1827, where "Crowther was one of its first students." 374 The College set out to do more than merely make available a British-style education to recaptives: it was one of the evolving tools of the colony for meeting its one of its original goals of introducing Christianity. Fourah Bay was meant to train African missionaries who could carry out such work on their own

${ }^{370}$ Schön and Crowther, Journals, 382.

371 Foreshadowing the difficulty of reinventing oneself as an Anglophone, Christian Sierra Leonean, Crowther details the harrowing journey faced en route. Rather than freeing those whom they had liberated, the Myrmidon and Iphigenia brought the captured Portuguese vessel down the Lagos River to the coastline and transferred the recaptives (thus clarifying the reason for that particular term) to British brigs. Over the next two and a half months, the British fleet made their way across the West African coast, a dangerous, arduous, and long journey. Northrup explains, "These 'recaptives' had also experienced the trauma of capture, the alienation from community, and an ocean voyage that regularly matched the Middle Passage in its length and miseries" ("Becoming African," 3). Crowther states that of the 187 people freed from the Portuguese, 102 perished on the way to Sierra Leone (Schön and Crowther, Journals, 381, 383).

\footnotetext{
${ }^{372}$ Schön and Crowther, Journals, 384.

${ }^{373}$ Walls, "Legacy of Samuel Ajayi Crowther," 16.

${ }^{374}$ Ibid.
} 
continent - a school, therefore, for being trained in the British rhetorical construction of Africa as that place in need of "Christianity, commerce, and civilization."375 James Frederick Schön, Crowther's missionary partner on the 1841 expedition, reiterated the ideology of Fourah Bay: "the key to evangelization of inland Africa lay in Sierra Leone." ${ }^{, 376}$ Crowther was a realization of that vision, albeit a revision: by the 1830 s, Sierra Leone would be a launch pad for evangelization not by white British missionaries, but by Anglicized African recaptives.

By 1841, the CMS sought to begin this evangelical work in earnest, organizing the ill-fated Expedition up the Niger River, ${ }^{377}$ and Crowther was tapped both as assistant missionary and local interpreter and guide. Hastings explains the irony that "Crowther was certainly a 'native' but he was not a native of the Niger,"378 a fact compounded by the Expedition's expectation that he work on the first-ever Yoruba dictionary on the coastal journey, a linguistic tool that would have no relevance on the lower Niger. ${ }^{379}$ Furthermore, Crowther's primary evangelical focus, which lead to his exclusive evaluation of Africans as either Christian or heathen, as well as ongoing proselytizing to

\footnotetext{
375 Ibid.

${ }^{376}$ Ibid.
}

377 See also Campbell, who writes that "In the 1840s... Britain began to adopt a more assertive policy" against the Atlantic slave trade. Specifically Thomas Buxton argued in The African Slave Trade and its Remedies "that coastal patrols alone would never stem the slave trade...[the] solution was 'legitimate commerce'....Buxton proposed sending expeditions into the interior along all major waterways, beginning with the Niger" ("Redeeming the Race," 137). Campbell adds, "Buxton's book was the direct inspiration for the 1841 British Niger Expedition" (138).

${ }^{378}$ Hastings, "Christian Life in the Age of Bishop Crowther," 345.

${ }^{379}$ See Walls, “The Legacy of Samuel Ajayi Crowther," for discussion of the start to "Crowther's literary career with the publication of Yoruba Vocabulary, including an account of grammatical structure, surely the first such work by a native speaker of an African Language" (16). 
both crew and Africans, did little to save the Expedition from being "an unmitigated disaster":

Within months, a third of the Europeans in the party had perished of fever; the model community established by the expedition's black settlers...survived scarcely longer. In years to come, the Niger venture would be widely lampooned as a symbol of the excesses of sentimental philanthropy, most memorably by Charles Dickens....Mrs. Jellyby's scheme to redeem Borriboola Gha in Bleak House is clearly modelled on the Niger Expedition. ${ }^{380}$

Crowther remained healthy, however, and the duties of ministering to the sick fell to him, a "service with the Niger expedition of 1841, with all its opportunity to widen the scope of his contacts and experiences" that drew the attention of the CMS. ${ }^{381}$ Hastings explains that while the Church Missionary Society "did not want to abandon the Niger Mission," they "feared to send white people to a region where they so rapidly died.",382 Crowther's seeming immunity to the ailments in the region that "became known as the White Man's Grave" suggested him an ideal candidate for further CMS efforts, and so in 1843 he was "brought to England for study and ordination" 383 before returning to Sierra Leone in order to mount a second mission.

He was not alone, as "by 1844, upwards of eight hundred Sierra Leoneans, known locally as 'Saros', had returned to Yorubaland."384 The Saros identity is essential to

${ }^{380}$ Campbell, "Redeeming the Race," 138; furthermore, the expedition failed, as Kass has written, because of "the lack of permanent interest among the African tribes" ("Dr. Thomas Hodgkin, Dr. Martin Delany," 380).

\footnotetext{
${ }^{381}$ McKenzie, Inter-religious Encounters in West Africa, 15.

${ }^{382}$ Hastings, "Christian Life in the Age of Bishop Crowther," 344.

${ }^{383}$ Walls, "The Legacy of Samuel Ajayi Crowther," 16.

${ }^{384}$ Campbell, "Redeeming the Race," 138.
} 
situating Crowther's rhetoric about Africans and Africa. As the "returned, educated

'Sierra Leoneans,"”

The Saros lived in two worlds. They had not been alienated from their native Yorubaland in the way that the black Americans settled in Liberia had been alienated from Africa. They were Yoruba-speakers, glad to be home, but they were also bearers of a new collective culture and religion of whose merits and superiority they were very conscious. ${ }^{385}$

Northrup has done much to explain how Sierra Leone amalgamated language and identity that had not existed collectively for the recaptives in their homelands. ${ }^{386}$ The contrived identity as Yorubans and Yoruba speakers created "the special two-world identity of the Saros, the Christianized Yoruba from Sierra Leone who returned from the 1840s to their native land to become a confident bridge between their new faith and their old culture." "387 Walls adds that one of the chief "criticisms of the 'Black European' missionaries from Sierra Leone...was their aloofness from native life," ${ }^{388}$ reflected in the privileging of their new identity, which Hasting describes as "Yoruba from Freetown, Christianized and in a way Anglicized yet not de-Yorubaized, returned...into the interior

${ }^{385}$ Hastings, "Christian Life in the Age of Bishop Crowther," 343, 351-2.

${ }^{386}$ See Northrup: "In the colony, Ajayi found no familiar faces from his hometown and only a dozen people who spoke his Oyo dialect. Unable to reconnect with the kinship network of his homeland, the liberated Ajayi continued the construction of a new community that encompassed the speakers of all the dialects of his language and their varied traditions that had seemed so strange to him as he had passed through their homelands on his long journey to the coast. The novelty of this broad new identification may be seen in the fact that in their homeland there was no commonly accepted name for the various dialects of the language or for the people who spoke it.... When Ajayi later compiled a dictionary and a grammar of that language and collected elements of the histories of those who spoke it, he called the language and people Yoruba, a name once used only for the northern part of the group. The subsequent creation of a panYoruba identity abroad (under this and other names) and then in the homeland has been so successful that this nationalist myth impedes grasping that the identity became meaningful at a particular historic moment" ("Becoming African," 5).

${ }^{387}$ Hastings, "Christian Life in the Age of Bishop Crowther," 350.

${ }^{388}$ Walls, "Black Europeans, White Africans," 246. 
to promote a style of Christianity."389 Sierra Leone's multicultural, multiracial, multilingual (at first) society ${ }^{390}$ thus situated Crowther in perhaps the prime foundational example of Gilroy's theorem of the Black Atlantic manifested in the metropole. His view of Africa and Africans, therefore, comes from a perspective complicated by these intersections and distancing him from the identity of his childhood accordingly.

Crowther's Journal takes place between 24 June 1841 and 31 October of that same year and documents the journey to the Niger Delta and up the river to Egga, inside Yoruba political boundaries. Crowther writes of the "Expedition," destined for "the Niger, the highway into the heart of Africa,"391 echoing recent British rhetorical practice of not differentiating the continent conceptually (like a being, it has a heart) as well as casting it as a place yet to be discovered (it requires his expedition to "this secret part of Africa"392). But more importantly Crowther situates the center (heart) of Africa in West Africa, revealing his rhetorical understanding of the continent (that the term "Africa" is proxy for West Africa). This notion is furthered when he speaks of his work on board to "fill up the Yaruba column of the Vocabulary of the African Languages," 393 the presumption of which was that such a vocabulary could be comprehensively contained in

${ }^{389}$ Hastings, "Christian Life in the Age of Bishop Crowther," 340, 341.

${ }^{390}$ Northrup writes of the "mutability of collective identity in migration," a factor which created the situation in which recaptives "learned for the first time in exile to think of themselves as Africans" ("Becoming African," 2), an essential insight about Crowther and how he later responds to the Africans he meets on his return to the Niger area. Northrup calls this Crowther's "inner journey of re-identification that accompanied the outer turmoil of captivity and alienation" (4).

\footnotetext{
${ }^{391}$ Schön and Crowther, Journals, 258.

${ }^{392}$ Ibid., 276.

${ }^{393}$ Ibid., 260.
} 
a volume, and that language was limited to West Africa. Such constructions of Africa echo the rhetorical imperialism enacted by the British in the founding of Sierra Leone

Crowther further affiliates himself with the British establishment, when he depicts himself as an ignorant outsider. At Cape Coast, he is given the use of the local "Interpreter...to allow me for the purpose of explaining any thing I should wish to know," 394 thereby casting himself as requiring interpretation so that he can know things, distancing himself from any identity that might accrue from being from West Africa twice over. Furthermore, Crowther writes of people he meets as "Natives," a move he continues upon arrival at the Niger, ${ }^{395}$ writing of "some huts, and Natives in them. The Natives were so timid, that they several times pulled their canoes ashore, and ran away into the bush; where they hid themselves among the grass, and peeped at the steamer with fear and great astonishment." 396 The term Native itself is distancing; and when he qualifies it with a description of people as cowering and fearful, it establishes him on the British side of the Christian/heathen-civilized/uncivilized dichotomy. Crowther employs the use of the term Native for Africans consistently throughout his journal, writing for example, "Many Natives made their appearance," "the Natives gazed at the steamers with wonder," "to engage the Natives to get wood," "our dresses were different from the Natives," or "the Natives have to make a kind of scaffold attached to the outside of their

\footnotetext{
${ }^{394}$ Ibid., 266.

${ }^{395}$ When Crowther disembarks briefly at the Gold Coast and reports finding the grave of Philip Quaque, the Ghanaian missionary whose life unbeknownst to him until this moment had mirrored and predicted his own, Crowther also refers to a missionary school "conducted by a Native of this place" (Schön and Crowther, Journals, 264). Later in that stopover, he writes, "It was very amusing to see the different dresses in which the Natives came to the Meeting, especially the women" (268). This continues throughout his description of the Gold Coast.

${ }^{396}$ Schön and Crowther, Journals, 275.
} 
huts. ${ }^{\prime 397}$ In so doing, he argues that he is the geographical, cultural, and ideological other, like the rest of the British.

Crowther writes that the Expedition leader Captain Allen "offered up a beautiful prayer for Divine protection, and for the success of the Expedition," after which "some could not help remarking that they were going to their graves."398 The concept of Africa as a place from which one required protection is not a new rhetoric. ${ }^{399}$ Crowther's endorsement of it, however, aligns him rhetorically as British, as does the subsequent anthropological approach in his journal, ${ }^{400}$ where he catalogs numbers, sizes, constructions, and layouts of huts, numbers of canoes and who was paddling them and how, and arrangements of agricultural establishments. Here Crowther, for example, uses the term "plantations" instead of farms, a British and American usage brought most recently from American and West Indies slavery nomenclature and serving as a poignant reminder of Scott Lyons's remark about the significance of who selects the terms of representation.

When he moves beyond the term Native, Crowther's concerns are both missionary and ethnographic: he depicts Africans early on as "a people who know no heaven, fear no hell, and who are strangers from the covenant of promise, having no hope, and without God in the world," but he also states that "the people are quiet, and of a friendly

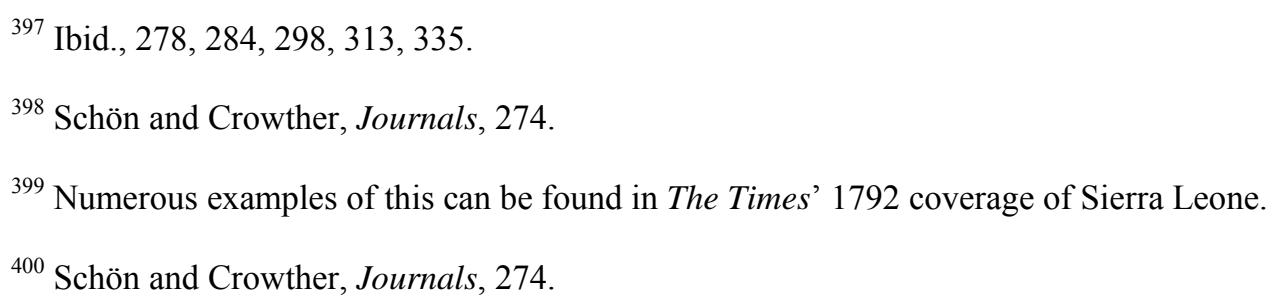


disposition" and "are very timid." ${ }^{\text {" } 01}$ His latter focus continues when he begins to specify rather than generalize Africans, such as when he arrives at Wappa:

They had on a great number of charms and gregrees about their hair, necks, wrists, and waists, decorated with beads and many cowries. Some had only dirty bits of cloth about their waists, and others about their shoulders; which, together with their smoky bows and arrows, and their dirty hair, plaited in different forms, gave them a complete appearance of barbarity. ${ }^{402}$

To the extent that such descriptive detail might curtail rhetorics of universalized Africans, the condescension involved in casting what he sees as inferior echoes further British rhetorics at the founding of Sierra Leone. Crowther also establishes the inferiority of the people in the "interior," repeatedly lamenting "how dirty they were," how "the village is so filthy, that the stench of it was insufferable," that "They are very ragged and dirty indeed...[in] this unpleasant village" and that "the streets are very muddy and filthy."403 Writing of a village named Bezzani, he states that it was "very filthy and muddy. Some of the houses had fallen in; others were ready to fall, and others were no better than pigsties, for their muddiness. ${ }^{, 404}$ Choosing to focus on dirt and the implicit clean point of view that would notice such dirtiness limits these representations of Africans to that which casts them as inferior in British eyes. Again it harkens back to Lyons's statement that "he who sets the terms sets the limits." Crowther both aligns himself with the great British rhetorical imperialist endeavor and provides further terms for it.

Such rhetorics do not form the entirety of Crowther's depiction of people along the Niger, however, and like preceding British rhetorics, depictions of inferiority are co-

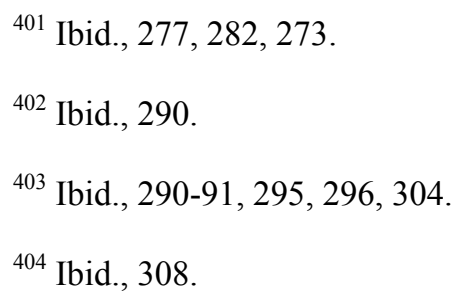


constructed with details of social organization and specifically described individual people. For example, Crowther states "that the Expedition was sent out on purpose to persuade all the Chiefs of Africa to do away with war and slave trade, ${ }^{, 405}$ and meetings to that end occur along the way with local leaders. The first such case was the meeting with King Obi:

He is a middle-sized man, between the age of forty and fifty; his countenance is soft, and he appears to be of a peaceful temper. Today his dress, as I was told, was very plain. He appeared in calico trowsers of a country make, and an English-made jacket of the same stuff: it would have been more respectable had they been cleaner, especially as he had no shirt on. He had on his neck three strings of pipe coral.... His Majesty was not a little proud of this new equipment from the Commander of the Expedition. He marched about the quarter-deck, with apparent satisfaction at having White Men for his friends....made a proclamation the same day, among his people, for the abolition of the slave-trade in his country. ${ }^{406}$

Here Crowther depicts a local political system and a unique individual differentiated from other Africans, and he simultaneously depicts his amusement at the King's simplistic, inferior nature. Similarly, he describes the Attah, the leader who because he "thought it was beneath his dignity to go into a canoe, the Commander of the Expedition, and his friends, were obliged to go to his majesty." ${ }^{407}$

When Crowther "passed Keri market: a great number of people were seen busying themselves about, ${ }^{, 408}$ one description among many of markets he began to see and describe, indicating his recognition of organized economies. One such compelling

\footnotetext{
${ }^{405}$ Ibid., 310.

${ }^{406}$ Ibid., 282-83.

${ }^{407}$ Ibid., 292.

${ }^{408}$ Ibid., 293.
} 
example of this was the extensive dye works described near the Kakandas, where he observes

the number of large country pots buried in the ground (or may properly be called pot-ponds), each containing from fifty to one hundred gallons of water, it appears that the dyeing-trade was carried on here to a great extent. I counted fifty-five of the larger of these ponds, about six feet in the ground, and about three feet in diameter. $^{409}$

Within this description is both technological sophistication on a grand scale, and an implied broad and substantial commercial customer base that would create the need for such a large production facility. Crowther's ongoing juxtaposition of dirtiness and political, economic, and cultural establishments echoes British rhetorics firmly established since the invention of Sierra Leone: Africa is inferior, yet organized enough to be fertile ground for British intent.

Yet Crowther was Yoruba, and the closer he gets to Yoruba political regions, the more his British rhetoric of Africans is mitigated by familiarity with what he sees. When he at last arrives in Egga, he abruptly and systematically attributes names to those he meets, the remaining distance between him and them limited to his Christianity and their Islam. For example, he writes, "We were first led to a man's house whose name is Aruna - he is considered as a gentleman in the town...Aruna led us to two elderly men, Legamah and Lusah...they introduced me to Rogang the Chief." ${ }^{410}$ In Yoruba, everyone and everything gets named, as he shows when he states that he "made inquiry regarding the interior," the answer to which he cites in two pages of explicit geopolitical detail, which the following excerpt exemplifies:

\footnotetext{
${ }^{409}$ Ibid., 297.

${ }^{410}$ Ibid., 314.
} 
Katunga, the capital of Yaruba, was deserted after the death of Abiohdung, the king of Yaruba. Atiba, the heir to the throne, removed the seat of government from Katunga to Aggoh, because the former was too near to Illorrin; while Oluyorle, the commander of the soldiers, or head warrior, took his seat at Kishi, otherwise called Ajanna, in confederacy with Ibariba, a people on the border of Yaruba, nearly speaking the same language. They have since had three battles : one at Igbodo, about seven years ago ; and another at Oshogbo, about three years ago ; in both of which Illorrin, headed by Sitah, a Fulatah, was defeated with great loss.... The principal towns in the country of Yaruba are the following : - Aggoh, Kishi, Ibaddang, Issehin, Shakki, Igboho, Ijaye, Iwo, Eddeh, Oshogbo, Illah, Awaye, and Wahsimi, belonging to Atiba ; and Illorin, belonging to the Fulatahs. Abbeh Okuta belongs to the Egba dialect, having Shodekkeh for its king. ${ }^{411}$

In Yoruba, Crowther is no longer an outsider, no longer in need of an interpreter, linguistically or culturally, and he sheds the anthropologically distanced tone that had echoed the British explorer rhetoric from the founding of Sierra Leone. To this point Crowther's journal echoes that British rhetorical imperialism of constructing Africans and Africa according to British terms, but here we hear a terminology unavailable to the British, who have as yet to receive a Yoruba dictionary from Crowther.

In Egga, Crowther selects the terms for describing Africa, referring to it not as Africa nor the people as natives or Africans, but rather according to the local practice of language in Egga in its rich diversity and specificity. Whatever glimpses of rhetorical sovereignty Crowther might give at this moment are however countered by his resumption and recitation of British intent with Africa. As he states to Rogang,

The Queen of the country called Great Britain has sent the King of the ship to all the Chiefs of Africa, to make treaties with them to give up war and the slave trade - to encourage all their people to the cultivation of the soil — and to mind all that the White People say to them; as they wish to teach them many things, and particularly the Book which God gives, which will make all men happy. I added, likewise, that there are many Nufi, Haussa, and Yaruba people in the WhiteMen's country, who have been liberated from the Portuguese and Spanish slaveships; that they are now living like White Men... and consequently are living a

${ }^{411}$ Ibid., 317-18. 
happier life than when they were in their own country, and much better off than their country-people are at present. ${ }^{412}$

Crowther proceeds to give Rogang an Arabic translation of the Christian Bible, and Roganag makes a gift of some Kola, ${ }^{413}$ both summoning each other symbolically and rhetorically to the place of their identities, and Crowther's mention of Kola without explaining what it is indicates the rhetorically complex place in which he arrives by the conclusion of the journey, immersed in both British rhetorical constructions of Africa and Africans and Yoruba identity and experience. For Yoruba is the conclusion: all the white people are sick, many are dead, and the expedition must turn around, and head down river to the coast.

Once back at sea, Crowther proclaims, "Surely the Lord has been with us, and delivered us from many dangers, both seen and unseen!" ${ }^{414}$ Different perhaps from the prayer for protection issued by Captain Allen upon the group's arrival at the Niger Delta, Crowther's affirmation of success in light of the disaster and death visited upon the white explorers indicates a successful avoidance of the danger of returning to Yoruba and not finding and establishing rhetorical sovereignty over himself and his identities. Crowther is remembered and memorialized in the merged identity of Bishop Samuel Ajayi Crowther, first Anglican bishop of Nigeria. And while for the British, as Hastings has written, Crowther "appeared to represent all they could hope for- - the bestowal of trust by Europeans upon an African, the incarnation of Victorian Christian values in a black

\footnotetext{
${ }^{412}$ Ibid., 314-15.

${ }^{413}$ Ibid., 317.

${ }^{414}$ Ibid., 337.
} 
skin, ${ }^{, 415}$ he also contested such appearances when he dedicated those long portions of his expedition journal to detailed specifics about his time in Yoruba regions.

To the extent Crowther might seem a tool of British endeavor, his invocations of British rhetoric might seem like mimicry, that sly civility Homi Bhabha writes of in The Location of Culture, a pretence of agreement underneath which is resistance (in this case attempts at rhetorical sovereignty) waiting to surface in Egga. Crowther's subsequent work as Bishop of Nigeria situates him, however, somewhere between Bhabha's sly Indian Pilgrim ${ }^{416}$ and Joyce Carey’s Mister Johnson, for Crowther while beholden to British determination is nonetheless empowered through both the expedition and the bishopric to an extent the disingenuous Indian Pilgrim and the obsequious Mister Johnson will never be. ${ }^{417}$ The lack of the sort of slyness Bhabha writes of suggests that Crowther's invocation of British rhetoric is no less sincere than his own expressions of rhetorical sovereignty at Egga. That he both enacts rhetorical imperialism and rhetorical sovereignty suggests the limitations of both entities: the case study of Samuel Crowther argues that British rhetorical imperialism is unable to control the rhetoric of Africa entirely, and African rhetorical sovereignty is unable to free itself entirely from that imperialism. Perhaps the question is not of sovereignty—which may be a misleading term if it implies an absolute state- but rather dominance, for as we have seen, Crowther found British rhetorics of Africa and Africans inescapable.

${ }^{415}$ Hastings, "Christian Life in the Age of Bishop Crowther," 340.

${ }^{416}$ Bhabha, The Location of Culture, 98-99.

${ }^{417}$ As with all Anglican bishops, Crowther's consecration required an Act of Parliament; it took place at Canterbury prior to his return to the continent. The Church of England does not offer honorific bishoprics, and thus Crowther was entered into the House of Bishops on spiritually the same ground as any other. 


\section{II: Martin Delany's Transatlantic African Experience}

I have outgrown, long since, the boundaries of North America, and with them have also outgrown the boundaries of their claims.

$$
\text { -Martin Delany }{ }^{418}
$$

Perhaps best known “as the American black community's first black

nationalist, ${ }^{, 419}$ Martin Robison Delany insisted that black liberation must be, in the words of Norman Haskett “extrinsic to an American identity." 420 Through much of Delany's career, this meant a focus on emigration - first to Central or South America, later to Africa - until the onset of the American Civil War suggested that American identity might be revised. Just months before the War began, Delany returned from a nearly twoyear expedition to West Africa undertaken to lay the groundwork for a colony in Africa to be founded entirely by African Americans. Delany's Official Report of the Niger Valley Exploring Party (1861) and its characterization of his first-hand experience of Africa from an avowedly African American point of view-one of travel and return entirely in the opposite direction of the Middle Passage- begs the question, like Crowther's writing before, of the extent to which African diasporant rhetorics served as counterpoint to British and American rhetorics about Africa. And what Delany's writing about Africa reveals is why the term diaspora is crucial beyond its basic geographic meaning: his Report demonstrates that the diaspora has as much to do with being immersed in a new locale as with living apart from the place of origin.

${ }^{418}$ Delany, The Condition, Elevation, Emigration, and Destiny, 343.

${ }^{419}$ Kahn, "The Political Ideology of Martin Delany," 415; see also Falola, "Introduction to The Condition, Elevation, Emigration, and Destiny," 7, 12.

${ }^{420}$ Haskett, “Afro-American Images of Africa,” 31. 
Delany's rhetoric of Africa and Africans is in far greater alignment with that of the American Colonization Society than his explicit opposition to their whiteness would suggest. While he takes issue with white control of initiatives in Africa-most specifically Liberia- he depicts Africans as heathen natives inferior to Christian African Americans, thereby demonstrating the great extent to which diasporant writing invoked British and American rhetorics. However much Delany refused to accept African American second class citizenship from white Americans, he equally invoked their assumptions that Africans were not Christian and were therefore uncivilized.

Preceding his departure for the Niger Valley, the events of Delany's life suggest that such views of Africans were so overwhelmingly pervasive in mid- $19^{\text {th }}$-century America that even an ardent black nationalist and emigrationist was not immune to them. Born free in Virginia in 1812, Delany moved with his family to Pennsylvania, where he trained as a physician and opened a practice in $1836 .{ }^{421}$ However, his interest in race politics began in this early period as well, most notably with the founding of his newspaper The Mystery in 1843 and later collaboration with Frederick Douglass on The North Star. ${ }^{422}$

His attempt to receive further medical training was formative, for when Delany matriculated into Harvard in 1850, he was the first of three African Americans to do so that year. ${ }^{423}$ Kass explains that "lectures began in November 1850, but in December, the three were asked to withdraw. Their presence was offensive to some of the white men in

${ }^{421}$ Kass, "Dr. Thomas Hodgkin, Dr. Martin Delany,” 374.

${ }^{422}$ Kass, "Dr. Thomas Hodgkin, Dr. Martin Delany,” 374. See also Adeleke, "Martin R. Delany's Philosophy of Education," 224; and Falola, "Introduction to The Condition, Elevation, Emigration, and Destiny," 8.

${ }^{423}$ Adeleke, “Martin R. Delany's Philosophy of Education,” 222. 
the class who had sent a written protest to the faculty."424 He withdrew, but the Harvard experience "made it clear to Delany that blacks could not and would not receive equal status with whites, regardless of ability," ${ }^{, 425}$ leading to his separatist ideology in opposition to Douglass's integrationist one. ${ }^{426}$

Outlining his ideological stance extensively in his first major work, The Condition, Elevation, Emigration and Destiny of the Colored People of the United States (1852), Delany advocates not mere separation from the dominant racist American political system, but outright emigration from the United States. According to Tunde Adeleke, the “depth and ubiquity of racism" were such for Delany "that Blacks could never achieve freedom and equality in the U.S., no matter how hard they struggled; thus, emigration was the only viable alternative." ${ }^{427}$ Delany chose to promote South America as the destination for such emigration, dismissing Africa in The Condition. Writing of Liberia, he states,

Its geographical position, in the first place is objectionable, being located in the sixth degree of latitude North of the equator, in a district signally unhealthy, rendering it objectionable as a place of destination for the colored people of the United States. We shall say nothing about other parts of the African coast, and the reasons for its location where it is: it is enough for us to know the facts as they are, to justify an unqualified objection to Liberia. ${ }^{428}$

${ }^{424}$ Kass, “Dr. Thomas Hodgkin, Dr. Martin Delany,” 375-6.

${ }^{425}$ Amalie Kass and Edward Kass, "Doctors Afield," 683.

${ }^{426}$ For more on the conflict between Douglass and his integrationist views and Delany and his emigrationist ones, specifically in the competing 1853 and 1854 conventions organized by each of them in Rochester and Cleveland, respectively, see Campbell, "Redeeming the Race," 131; Adeleke, "Martin R. Delany's Philosophy of Education," 229; and Kahn, "The Political Ideology of Martin Delany," 416.

427 Adeleke, “Martin R. Delany's Philosophy of Education,” 229.

${ }^{428}$ Delany, The Condition, Elevation, Emigration, and Destiny, 185. 
Delany rejects Liberia because it is a white invention (despite its declaration of independence five years earlier, in 1847). Robert Kahn explains that for Delany, "Colonization is a white-initiated movement that would forcibly remove all free blacks from the United States in order to protect the institution of slavery," whereas emigration "is a black-initiated, voluntary movement that takes the destruction of slavery as one of its important aims. The freeman chooses emigration in the belief that, by amassing political and economic strength in a nation of his own, slavery can be rendered impolitic and, most importantly, unprofitable." ${ }^{429}$

Colonization had divided the political resistance to American slavery among blacks from its inception. For example, "most black leaders" writes James Campbell, "eschewed any discussion of Africa, lest they be tarred as "Colonisationist"” and "in 1835, the newly formed National Negro Convention formally renounced the label 'African', long the standard term of reference for people of colour in the United States. ${ }^{.430}$ Nonetheless, Delany seems to keep Africa in reserve: the appendix to The Condition is entitled "A Project for an Expedition of Adventure, to the Eastern Coast of Africa," the east coast helping to differentiate such a project from Liberia while simultaneously reappropriating the continent in a pan-African sensibility that would merge the continent and the Diaspora in a joint project.

William Haskett has suggested that "before black self-reliance and self-elevation could become operational, the image of Africa would have to be redeemed — that image

${ }^{429}$ Kahn, "The Political Ideology of Martin Delany," 418-19; see also Blackett, "Martin R. Delany and Robert Campbell," 2; Kass, "Dr. Thomas Hodgkin, Dr. Martin Delany," 376; and Falola, "Introduction to The Condition, Elevation, Emigration, and Destiny," 10-11.

${ }^{430}$ Campbell, "Redeeming the Race," 129. See also Kass and Kass who write that Delany "ruled out Liberia, which he continued to view as subservient to its American sponsors even though its independence had been declared in 1847" ("Doctors Afield," 683). 
of Africa as being desolate, the inhabitants of which were 'savage, lazy, idle, and fit only for bondmen." ${ }^{431}$ Pan-Africanity that would liberate African Americans from the scourge of slavery was accompanied by a hierarchy in which African Americans were destined to save the benighted Africans. This is what Wilson Moses refers to as the "the doctrine of the fortunate fall,", ${ }^{432}$ a vision of slavery as "providential, a preparation ordained by God to equip them to carry the light of the gospel back to their native land, ${ }^{, 433}$ familiar from Samuel Crowther's early narrative. As Campbell suggests, Delany and his emigrationist colleagues "claimed the right, indeed the obligation, to 'redeem' Africans, to remake their 'benighted' brethren in their own, higher image.,"434 Repeated here is the hierarchy within the Black Atlantic of Christian determinism, which works both to save and to civilize: thus the rhetorically loaded term "benighted," Delany's use of which echoes the precise construction of Africans by American colonizationists for the preceding forty years. Indeed, when Delany sought funding for his Expedition, he couched his effort for "the enlightenment and civilization of the African race," indicating a convergence of politics and missionary ideology. ${ }^{435}$

Delany's various biographers agree that what brought him at last around from critiquing Liberia to planning a trip to Africa meant to lay the groundwork for a new settlement was his reading of "Bowen's Central Africa and David Livingstone's

\footnotetext{
${ }^{431}$ Haskett, "Afro-American Images of Africa," 33.

${ }^{432}$ Qtd. in Campbell, "Redeeming the Race," 127.

${ }^{433}$ Campbell, "Redeeming the Race," 127.

${ }^{434}$ Ibid., 128.

${ }^{435}$ Qtd. in Blackett, "Martin R. Delany and Robert Campbell," 5; referring to when "Delany requested support from the fund of $\$ 150,000$ left by the Pittsburgh philanthropist Charles Avery."
} 
Missionary Travels and Researches in South Africa." ${ }^{, 436}$ Furthermore, Bowen's text inspired Delany to select Abeokuta (Nigeria) as his destination, and Livingstone's "naturalist-explorer" narrative gave Delany a structure for his own book. ${ }^{437}$ But it was the increasing legal pressures on African Americans in the 1850s, the culmination of which was the Dred Scott decision in 1857, that coalesced with other factors-an established ideological separation from the ACS's Liberia effort, the activism of both the Chatham, Canada emigrationists and the Cleveland Conventions - to provide the impetus at last for Delany to go to Africa.

The mindset with which he departed cannot be understated. His radical resistance to any white influence (from Liberia to his refusal at first to accept expedition funding from white people) suggests that he would also resist white rhetorics about Africa, yet the flashes of Christian superiority he already expressed in his earlier works suggests the rhetorical limits of his black nationalistic and separatist beliefs. His radical politics therefore make him all the more poignant of a case study for the limits of rhetorical sovereignty; for arguably if anyone in $19^{\text {th }}$-century America were likely to resist white rhetorical imperialism, Martin Delany would seem a likely candidate. That the rhetoric of benighted and inferior Africans he utilizes before departure is not contested through the course of his expedition suggests surprisingly a greater limit to his rhetorical

${ }^{436}$ Blackett, "Martin R. Delany and Robert Campbell," 3. See also Kass, "Dr. Thomas Hodgkin, Dr. Martin Delany," 377; and Campbell, "Redeeming the Race," 133.

437 See Campbell, "Redeeming the Race," 133, both for the passages quoted here and for these two concepts of what Delany invoked from Bowen and Livingston. Campbell later writes of Delany's literary "[debt] to contemporary European writing about Africa....[C]ast as journeys of 'exploration' and rendered in the language of natural science, the standard idiom of nineteenth-century accounts of the 'Dark Continent'....Delany's text, in particular, conformed to the conventions of the form, with long discussions of climate, the prevalence and prevention of disease, mineral resources, fertility of the soil...commercial opportunities, flora and fauna, animal husbandry... and personal hygiene for the traveller" ("Redeeming the Race," 141-42). For his own discussion of the influence of these two works, see Delany, The Condition, Elevation, Emigration, and Destiny, 241. 
sovereignty than to Crowther's; however, that he does not refer to Africa as benighted during the expedition indicates some contestation, particularly his view of how Africa would be redeemed once in the hands of African Americans and under their guidance.

As has been shown, Martin Delany set sail with a preconceived notion that Africa was a degenerated place, in which Africans were in need of redemption, and that Christian African Americans could be the redeemers, echoing Crowther's basic binary of an Africa divided into Christian and heathen. Turning to the central text to be analyzed in this section on Delany-his Official Report of the Niger Valley Exploring Party — the shape of his rhetoric of Africa quickly becomes apparent. Early in his Official Report, he states that he will "go on an independent and voluntary mission-to travel in Africa"; he refers shortly to his "mission to Africa," and later writes of "our Mission to Africa." 438 When he further claims himself among "the leading advocates of the regeneration of Africa," ${ }^{439}$ he assumes a historical antecedent of degeneration there, a notion of the fall associated with the categorization of Africa as benighted: the land once great that became lesser. ${ }^{440}$ And so he is both missionary and echo of the rhetoric of Liberia, that white invention he resists so ardently. This crisp repetition of such rhetoric reaffirms the rhetorical hold on Africa by outsiders, and the limits on how much rhetorical sovereignty might be achieved.

${ }^{438}$ Delany, The Condition, Elevation, Emigration, and Destiny, 236, 241, 361.

${ }^{439}$ Ibid., 237.

${ }^{440}$ He defines degeneration in the American context in The Condition, Elevation, Emigration, and Destiny as the distance between citizenship and the status of African Americans in American society. See Kahn, "The Political Ideology of Martin Delany," 426. 
The Expedition is, he proclaims, "the grandest prospect for the regeneration of a people, that ever was presented in the history of the world." about to establish a policy of self-regeneration in Africa, which may, by example and precept, effectually check forever the nefarious system, and reform the character of these people." ${ }^{442}$ If regeneration is a project to be performed upon Africans, a clear line of demarcation is drawn between the agents of this change and those who would receive it—-"these people," the Africans themselves. "I had but one object in view_-" writes Delany, "the Moral, Social, and Political Elevation of Ourselves, and the Regeneration of Africa." ${ }^{443}$ By achieving the salvation of Africa, Delany would enhance the ethos of African Americans, shifting sensibilities about them from inferiority of a literally lesser grade of humanity ${ }^{444}$ to those of great moral contribution, thus regenerating them as well. Africa remains in this, importantly, an afterthought or merely a means to an end rather than a serious consideration in its own right.

While Delany's rhetoric of Africa and Africans in the Official Report is condescending, he does not explicitly portray Africa with that lens: rather, in spite of the implication of a degenerated Africa, the language he uses actually to refer to the continent is strikingly plain. Over the course of chapters IV-XIII of Official Report-the part of his text consisting of his travel journal—-he uses the word Africa approximately 95 times. On no occasion is it appended with or modified by evaluative or moralizing adjectives. Instead, Delany leaves the word to stand by itself, typically using it as the

\footnotetext{
${ }^{441}$ Delany, The Condition, Elevation, Emigration, and Destiny, 333.

${ }^{442}$ Ibid., 350.

${ }^{443}$ Ibid., 243.

${ }^{444}$ See discussions of polygenism in Chapter IV below.
} 
object of a preposition. For example, he writes of "other parts of Africa," "to us in Africa," "reptiles of Africa," "through different parts of Africa," "welcomed me to Africa," "another part of Africa," and so on ${ }^{445}$ all of which align more with the earlier rhetorics of the founding of Sierra Leone rather than adopting those of Liberia.

Delany further echoes those earlier rhetorics in his construction of Africa as a singular entity, indicated by his reference to "the interior," which disregards internal political boundaries and replaces them with a holistic notion that one is either in or out of Africa. He writes of "a good deal of ivory from the interior," that "Ivory enters largely into commerce, being brought by 'middle men' from the distant interior," or of "our return from the interior. ${ }^{" 446}$ Collectively this resonates with his pan-African sentiments of Africa as a country, such as when he refers to Africa as "that country," offers advice "when first going to Africa," or describes factors that "contribute largely to health in Africa, as in other countries. ${ }^{, 477}$ His comfort with assuming that one's experiences in one part of Africa will transfer to the entire continent align him—like Crowther beforewith rhetorical trends about Africa since (at least) the 1780s, indicating that he draws on that rhetorical heritage in spite of the ideological challenges such emulation poses (i.e., his determination to resist white influence). It is all the more telling of the hegemony of that rhetoric that Delany's resistance to overt white involvement does not preclude him from invoking and repeating rhetorics of white writers.

${ }^{445}$ Ibid., 268, 248, 248, 255, 258, 281.

${ }^{446}$ Ibid., 265, 293, 300.

${ }^{447}$ Ibid., 249, 322, 323; note in this example how he parallels Africa with "other countries," indicating his sense of it as one. 
In that vein, Delany — presumably to promote emigration to Africa—quickly establishes a positive outlook, writing of "Africa, with its rich, inexhaustible productions, and great facilities for checking the abominable Slave Trade, ${ }^{, 448}$ echoing rhetorical trends from both the founding of Sierra Leone and Liberia. Delany paints Africa as the land of milk and honey and a power for good; if it is now degraded, then its potential once regenerated is radical, an only slightly exaggerated version of the same rhetoric Lydia Maria Child painted when describing ancient Ethiopia three decades before. He reiterates historical rhetorics of the viability of Africa for production and the importance of commerce when he envisions the transformation of plantation cotton production to Africa as domestic paid labor: "Africa possesses resources," he writes, "which, properly developed, must doubtless render her eventually a great, if not the greatest, producer of all the products of Slave Labor." ${ }^{449}$ This familiar echo of the Sierra Leone Company's rhetoric about exporting African productions and moving sugar production from the West Indies to West Africa is both a positive view of Africa and limiting (i.e., implication that Africans are meant to be laborers). Indeed, Delany seems repeatedly bent on rejecting negative depictions of Africa such as when he writes, "Then all this cowardly cant about the unhealthy climate, the voracious beasts, and venomous reptiles of Africa, will be at a discount, instead of passing current as now for wisdom and prudence. ${ }^{, 450}$ Much of what Delany writes in promotion of Africa could easily be mistaken for the Sierra Leone Company's first investor prospectus.

\footnotetext{
${ }^{448}$ Ibid., 237.

${ }^{449}$ Ibid., 249.

${ }^{450}$ Ibid., 248.
} 
A difference in Delany's rhetoric of Africa from hegemonic white rhetorics, however, is that his generalizations of Africa generally appear in close proximity to specific names and portrayals of towns and regions. For example, his chapter title beginning with "The Interior" continues with the appositive "Yoruba," a move he repeats when he speaks of "The domestic trade among the natives in the interior of our part of Africa—Yoruba." ${ }^{251}$ His specificity actually begins with his travel plan - "to proceed to Lagos, thence through Abbeokuta to Rabba, on the Niger, about 350 miles from the coast," ${ }^{452}$ and it continues as he journeys through Liberia. "I left Monrovia in the bark Mendi," he writes, "stopping at Junk, Little Bassa, Grand Bassa mouth of St. John's River, Sinou, arriving at Cape Palmas. ${ }^{, 453}$ Such specifics throughout counter his universalized or even regionalized sensibilities about Africa and distinguish him from those previous rhetorics of founding Sierra Leone and Liberia that were less interested in specifics than they were in what Africa could do for them. He too has a plan for Africa, but he bothers to represent it in detail, like Samuel Crowther in Egga. Such details are beyond what appeared to be thought necessary for colonization by writers constructing Africa in the Sierra Leone and Liberia eras, so Delany's rhetorics of the Niger Valley begin to paint a picture of resistance to those rhetorical imperialisms.

This is not to say that Delany intentionally couched his descriptions in a way that they would resist white rhetorics of Africa, despite his explicit intention to resist white influence in his project with Africa. Rather, it suggests the latter desire resulted in his acts of rhetorical sovereignty perhaps even unwittingly. This broadens Lyons's notion of

\footnotetext{
${ }^{451}$ Ibid., 284, 356.

${ }^{452}$ Ibid., 249-50.

${ }^{453}$ Ibid., 259-60.
} 
rhetorical sovereignty, extending to rhetorics that arise organically without specific rhetorical intent but born of other desire for resistance. In this way, Delany's desire to have an Africa free of Liberia echoes Crowther's representation of Egga free of the Otherness prescribed by the British expedition to explore and discover the Niger Valley. That both Delany's and Crowther's rhetorics of Africa and Africans involve an interplay between rhetorics they inherited and those more of their own making reiterates that rhetorical imperialism and sovereignty are not an either-or scenario, but rather one of ongoing tension and adjustment. Delany's comfort with white rhetorics about Africa complicates this interplay further because it reveals that they were not exactly white rhetorics, but rather non-African ones, a stark revelation of how close white and diasporant rhetorics were to each other in spite of their political distance. The irony of the alignment of Delany's diasporant rhetoric with white colonizing rhetoric, while he fought so fervently for explicit distance from white society, is all the more revealing of the power of that colonizing rhetoric to inform all rhetoric about Africa.

A clue to the extent of Delany's invocation of preceding rhetorics about Africa is suggested by James Campbell, who argues that when writing the sections on physical and human geography in the Report, Delany invoked the $19^{\text {th }}$-century naturalist-explorer narrative trend of cataloging Africa in the $19^{\text {th }}$ century. ${ }^{454}$ These passages are intimate, magnified depictions of the landscape, both natural and domesticated. Delany writes about the Yoruba Region,

The first plateau or low land from Lagos, extends about thirty-five or forty miles interiorly, with but occasionally, small rugged or rocky elevations breaking the surface, when it almost abruptly rises into elevated lands, undulating and frequently craggy, broken often by deep declivities of glens and dales...The soil

${ }^{454}$ Campbell, "Redeeming the Race," 141-42. 
of the first plateau, for ten or fifteen miles, is moist and sandy, more or less, gradually incorporating with a dark rich earth....the whole being exceedingly fertile and productive; as no district through which we traveled was without cultivation more or less, and that always in a high degree, whatever the extent of ground under cultivation or the produce cultivated. ${ }^{455}$

Such a lush description, Campbell argues, echoes the kind of naturalist approach to the African landscape taken by Bowen and Livingstone, and to do so at first blush it seems at odds with what might be expected of a black nationalist. Yet Delany's depiction of it as a landscape both rich in offerings and in utilization, a fecund place of nonetheless organized productivity, suggests it fit for mass settlement, all of which aligns him with rhetorics of the founding of Sierra Leone far more explicitly than with those of Liberia. Again, this is not to say that Delany intentionally invoked Sierra Leone, but rather than in intentionally avoiding any recognizable rhetorics of Liberia, he retrieved others, a reminder of how Liberia's rhetorics of Africa were built upon rather than replacing those from Sierra Leone.

Delany later writes of "the beautiful clear country" rich with "recent timber to be found growing on the lands" and "perennial streams...both good-tasted, and if the constant use of running stream water be a fair test, I would decide as wholesome. ${ }^{456}$ Such an accommodating natural environment, one already proven by the local population to support productivity, creates a rhetoric of Africa not as an ambiguously Edenic land of milk and honey, but rather one of usable natural resources. Delany argues that it is, in short, a place in which to go and invest, the latter being one of the keys to his immigration scheme. Regardless of the precise goal Delany has in mind (the settling of

\footnotetext{
${ }^{455}$ Ibid., 288-89.

${ }^{456}$ Ibid., 312.
} 
Africa by his own people versus the settling of Africa by another people), the rhetoric of objectification of Africa is all the same: not deviating from the rhetoric of prior travel writing about Africa, Delany too holds it up as if a piece of fruit to be studied for ripeness before purchase.

His goal of replacing American slave cotton production with African paid labor cotton production (indicating that he followed in the trend of thinking how best to use Africa) relied on an ability to cultivate, process, and export. The environment specific to the Yoruba region facilitated the first requirement of cultivation. His discussion of processing facilities such as "iron smelting works" and the fact that the people "manufacture brass," ${ }^{457}$ along with other such technical productions demonstrated African ability to meet the second. And his depictions of the port of Lagos revealed an export infrastructure already in place: "The trade of this port," he writes, "now amounts to more than two millions of pounds sterling, or ten millions of dollars, there having been at times as many as sixty vessels in the roadstead. The merchants and business men of Lagos are principally native black gentlemen." ${ }^{, 458}$ And in terms of scale, Delany explains that Lagos' port economy serves numerous massive upriver towns and cities:

From Abbeokuta, population 110,000, we proceeded to Ijaye, population 78,000, reckoned by the white missionaries and officers of the Niger Expedition of Her Majesty's service, who passed through once, at 80,000; Oyo, population, 75,000; Ogbomoso, population 70,000; Illorin, population 120,000; returning back, via Ogbomoso to Oyo, passing through Iwo, population 75,000; and Ibaddan, population 150,000 an immense city, the estimated number of inhabitants by the Civil Corps who passed through, being 250,000...the population is immense and the city extensive, the walls embracing an outline of at least twenty-three miles. ${ }^{459}$

\footnotetext{
${ }^{457}$ Ibid., 289.

${ }^{458}$ Delany, The Condition, Elevation, Emigration, and Destiny, 347-48.

${ }^{459}$ Ibid., 286-87.
} 
Such descriptions argue compellingly for Delany's dream of replacing slave plantation cotton production with Africa laborers working for their own benefit as well as for the regeneration of the continent. Yet, even a port flush with cash, enormous metropolitan populations, and technological productions are not enough to supplant the image of an inferior Africa Delany is immersed in.

The specific term civilization is a flashpoint in Delany's Report for precisely this contradiction. For example, in reference to house construction, he suggests in future settlements the use of "Venetian jalousies now in use in civilized countries," countries other than the Yoruba region, and other than in Africa. He shortly repeats this distinction, when referring to ants in Africa destroying clothes that pale in comparison to "moths which get into the factories and houses in civilized countries, where woolen goods are kept."461 That he paints such a complex, developed, favorable image of a distinct, specific area - the Yoruba region-while still maintaining that it is out of Africa where one finds civilization calls for an interrogation of the way he constructs Africans themselves. For it is them upon which the burden of civilization rests or falls. Delany's rhetorics of Africans helps to clarify the contradiction of his comfort with depicting a port trading in tens of millions of dollars of merchandise that is nonetheless uncivilized, for unlike prior rhetorics of Sierra Leone and Liberia based on rural settlements distant from cultural metropoles, Delany had specific evidence to the contrary before his eyes.

The most common term Delany uses to refer to Africans - and he does so about ninety times in the section of his Official Report covering his time in Africa-is native.

\footnotetext{
${ }^{460}$ Delany, The Condition, Elevation, Emigration, and Destiny, 326.

${ }^{461}$ Ibid., 327.
} 
This term appears casually throughout the text, at times as an adjective, and often as a stand-alone, unmodified noun. He is interested in "the disposition of the Natives," the "palm oil burnt in native manufactured lamps," the "simple pathways in true native style," and if one were to "settle among the natives."462 There is "the mail-boat managed by the natives," at the mission "many natives, both adult and children, who could speak, read, and write English," and the "joyous acclamations of the numerous natives" who welcomed Delany's arrival. ${ }^{463}$ While there is no need to go into detail of what Sartre and Fanon established long ago regarding the use of the term itself, what these natives are is precisely what Delany is not.

At the same time, however, Delany repeats often his investment in the concept of “my race," which he defines explicitly as "Africa for the African race and black men....By black men I mean, men of African descent who claim an identity with the race." ${ }^{464}$ So for Delany, natives are both what he is - that which he hails as a race identity matching his own - and simultaneously the manifest other: familiar yet distant. By classifying the people he encounters as natives (rather than any other term he could have applied to them), he characterizes himself irretrievably as non-native, as outsider. This binary works similarly to the distinction between the interior of Africa and the coast, with a unifying factor not having to do with anything intrinsically common in Africans, but rather in the extrinsically common quality of being the opposite of African American emigrationists.

\footnotetext{
${ }^{462}$ Ibid., 250, 291, 275, 336.

${ }^{463}$ Ibid., 285, 335, 254.

${ }^{464}$ Ibid., 300, 358; see also 257, which refers to the lecture he delivered in Monrovia entitled "The Political Destiny of the African Race."
} 
Delany makes a subtle distinction with the use of this term when he suggests on several occasions that there are civilized natives, a seeming contradiction since part of the point of African American emigration to Africa was to civilize the Africans. Delany writes of such civilized natives, revealing the common thread that makes them so:

our excellent, faithful, and reliable guide, Spear Mehia is, [sic] a native civilized Christian Prince, the son of the old friend of the missionaries, Nmehia, the deceased King of Kavalla,

and

William Johnson our cook, the only servant we retained — a civilized native - as guide and attendant,

and lastly

a large assemblage waiting, among whom were Messrs. Samuel and Josiah Crowther, H. Robbing, J. C. During, F. Rebeiro, and C. W. Faulkner, civilized native gentlemen. ${ }^{465}$

All of these individuals are Christian—identified specifically as such or bearing Anglicized names stemming from baptism. The question of what it is to be civilized-a question that has plagued the rhetorics of Africa and Africans since at least the late- $18^{\text {th }}$ century — is here clarified: it is not a question of Christian Civilization, but rather of understanding that to be civilized is to be Christian.

That equation is not quite reversible: Christianity in and of itself is not quite enough, according to Delany, to civilize, but rather a starting point from which all accoutrements of civilization flow. He writes of progress occurring "wherever enlightened Christian civilization gains an influence" or of the support he received "to aid

${ }^{465}$ Delany, The Condition, Elevation, Emigration, and Destiny, 274, 287, 296. 
the spread of civilization through the gospel and education." ${ }^{.466}$ And when he cites the treaty he secured for settlement in "Abbeokuta," he explains

that the settlers shall bring with them, as an equivalent for the privileges above accorded, Intelligence, Education, a Knowledge of the Arts and Sciences, Agriculture, and other Mechanical and Industrial Occupations, which they shall put into immediate operation, by improving the lands, and in other useful vocations. $^{467}$

The common thread here has to do with the key terms enlightened, education, and

knowledge, for what is required to civilize is a combination of Christianity and education:

those who have both, are.

What Delany means by Christianity is clear. The notion of education, however, is murky as soon as it is mentioned. What exactly constitutes education in this framework that needs to be learned in order to be civilized, in addition to the Christian requirement? He answers this in thorough detail:

There are other measures and ways by which civilization may be imparted than preaching and praying - temporal as well as spiritual means. If all persons who settle among the natives would, as far as it is in their power and comes within their province induce, by making it a rule of their house or family, every native servant to sit on a stool or chair; eat at a table instead of on the ground; eat with a knife and fork (or begin with a spoon) instead of with their fingers; eat in the house instead of going out in the yard, garden, or somewhere else under a tree or shed; and sleep on a bed, instead of on a bare mat on the ground; and have them to wear some sort of a garment to cover the entire person above the knees, should it be but a single shirt or chemise, instead of a loose native cloth thrown around them to be dropped at pleasure at any moment exposing the entire upper part of the person - or as in Liberia, where that part of the person is entirely uncoveredI am certain that it would go far toward impressing them with some of the habits of civilized life. ${ }^{468}$

\footnotetext{
${ }^{466}$ Ibid., 350, 297.

${ }^{467}$ Ibid., 299.

${ }^{468}$ Ibid., 336-37.
} 
While Delany is not the first to suggest that those coming to Africa should employ Africans as servants in their homes in order to alter them, the detail to which Delany goes is striking and revealing. Taken as a whole, Delany's statement here describes a world of manners (i.e., the accoutrements) that must be learned and practiced alongside Christianity in order to attain civilization.

And so what is more important in terms of civilization than a lucrative trading port doing millions of dollars of business is the ability to use a fork. After all of Delany's anti-Liberia rhetoric and arguments for refusing white influence or involvement, he invokes precisely the same Christianizing rhetoric that defined the Liberian era. Not using the term benighted or referencing an Africa fallen from a once-great past belies the fact that Delany nonetheless portrays Africa and his endeavor with it in precisely the same way as the American Colonization Society had forty years before, indicating how pervasive and unavoidable rhetorical imperialism may be.

Such a subjective criterion is primarily indicative, however, not of cultural disdain, but rather of the distance Delany would place between African Americans and Africans in order to establish the clear hierarchy within the race necessary to his project. If Providence created slavery so that African Americans could return to Africa with Christianity, the presumption Delany makes is that Christianity was accompanied by a broader set of manners that must also be transferred to Africans in order to accomplish Christian civilization. To that end, he must point out Africans' inferiority precisely enough to justify the presence of African Americans, for the conclusion of the line quoted earlier is, "Africa for the African race and black men to rule them." ${ }^{469}$ However distant

\footnotetext{
${ }^{469}$ Ibid., 358.
} 
from white versions of and influence on Africa Delany might desire to be, he nonetheless perfectly recreates past rhetorics of an Africa that will necessarily submit to non-African interests.

Delany's hierarchy privileging diasporants above Africans aligns him with British and American views of Africa and Africans. And while it might seem to call into question his black nationalist and Pan-African ideologies, it perhaps is a better indication of the difficulty of disentangling oneself from American and British rhetoric of Africa. This privileging of diasporants and accompanying painting of Africans as inferior is woven throughout his Official Report. One such example is when he writes of "a meeting of the native cotton-traders, chiefs, and others...held at the residence of the great chief Ogubonna": before proceeding, the chief summons Delany and his African American counterpart Robert Campbell because "we knew how things ought to be done." ${ }^{470}$ At the same moment that Delany characterizes a chief as being "great," he establishes the chief's inferiority by quoting the chief's own words to this effect.

Further critiques ensue, such as when he addresses sanitation: "One important fact, never referred to by travellers as such, is that the health of large towns in Africa will certainly be improved by the erection of cesspools, whereas now they have none. With the exception of the residences of missionaries and other civilized people, there is no such thing in Africa." ${ }^{471}$ The critique here works further to establish this hierarchy between African Americans and Africans in the way it relies on Delany's sense of such knowledge as normative, a move that excludes Africans from it explicitly. To wit,

\footnotetext{
${ }^{470}$ Ibid., 296.

${ }^{471}$ Ibid., 331.
} 
civilization has to do with cesspools, and so Africans, who deal with their waste differently, are according to this criterion uncivilized. Even Yoruba parenting falls under his scrutiny: he begins with a compliment—-"The children are also passionately beloved by their parents" — but concludes with the familiar condescension — "sometimes with too much indulgence. ${ }^{, 472}$ Here he operates confidently as if in a position to pass judgment, the confidence lying in an assumption the reader will agree. In fact, Delany's overall critique of Africans rides entirely on his comfort with this: that African American readers (specifically the target emigrationist African American readership) are already predisposed to a sense of superiority over Africans, that they too are immersed in mainstream American rhetoric of Africa, in spite of their resistance to mainstream American rhetoric of themselves.

With "native progress" in mind and the hierarchy established between who will encourage that progress and who will experience it—specifically those who have "advanced" or "higher intelligence" and those who have not yet "attained it"—Delany writes that "the improved arts of civilized life must now be brought to bear." in a section entitled "What Africa now Requires," broader civilization combine, and the risks if they do not: "Christianity certainly is the most advanced civilization that man ever attained to, and wherever propagated in its purity, to be effective, law and government must be brought in harmony with itotherwise it becomes corrupted, and a corresponding degeneracy ensues, placing its

\footnotetext{
${ }^{472}$ Ibid., 308.

${ }^{473}$ Delany, The Condition, Elevation, Emigration, and Destiny, 340, 341, 341.

${ }^{474}$ Indicative of the rhetoric of Africa as a place in need.
} 
votaries even in a worse condition than the primitive." ${ }^{475}$ This is the first and only time Delany employs the problematic term primitive to depict Africans, ${ }^{476}$ and its use exaggerates even the Christian/heathen binary employed by Crowther as well as the Liberian-era rhetorics that privileged the same. It takes on more striking proportions when we consider the linguistic correlates of primitive: while primal or primeval are inappropriately naturalized for comparison, primary underscores the location of unChristianized Africans on Delany's continuum of blackness. They are first, originary, yet fixed and without agency for change. ${ }^{477}$

Delany cannot extract himself from imperial rhetoric about Africa. For even though he has the evidence of African civilization, society, and accomplishment right before his eyes - cities, civic governance, and citizens - he maintains the rhetoric of an Africa in need. His efforts at promoting Africans, in particular the "the intelligent and advanced Yorubas"- whom he again elevates when he writes, "Such a people as the Yorubas and other of the best type"-must be read as promotions of them as both future exemplars for other Africans ${ }^{478}$ and targets for the beginning of his efforts to meet Africa's needs (much as the British placed their hopes in the amalgamated Sierra

${ }^{475}$ Delany, The Condition, Elevation, Emigration, and Destiny, 340.

${ }^{476}$ A term in common use at the time within evolutionary science debates.

${ }^{477}$ In this characterization lies hints of the Dark Continent rhetoric of an Africa eternally fixed in a retrograde state, a rhetoric to arrive less than twenty years after Delany's return from Africa.

${ }^{478}$ Ibid., 347, 359. Delany's argument of the primacy of the Yorubas is not unfamiliar, given Crowther's experiences and prior advocacy of them, as well as Bowen's; however, the limitations brought by Delany's inexperience in a broader African context causes the myopic nature of his view. This issue is starkly dramatized when he writes of "the superiority of the people in our part of Africa, and what may be expected of them compared with some in other parts; and how the Portuguese influence has ruined them" (377). Such a sentiment reiterates the belief in hierarchy Delany had established, extending it beyond African Americans and Africans to one among the regions of Africa as well. 
Leoneans, or the Americans in the Americo-Liberians). To that end, Delany's representation of the Yoruba as a complexly organized and diversified society does much to begin the rehabilitation process Delany sets out to accomplish in his project; however, the nature of that rehabilitation has to do with a different destiny for the Yoruba than becoming equals of Delany's emigrationist African Americans.

The purpose for which Delany portrays the fertility and friability of the Yoruba region and the steadfastness, organization, and productivity of the people is nothing other than the production of cotton, which "is here raised in the greatest quantities, we having frequently passed through hundreds of acres in unbroken tracts of cultivated land." ${ }^{479}$ Indeed, "the African," writes Delany, "as has been justly said by a Manchester merchant, has in all ages, in all parts of the world, been sought to raise cotton wherever it has been produced.." ${ }^{480}$ Delany's conclusion of his expedition and project is to make explicit a seemingly naturalized connection between the growing of cotton and Africans, regardless of whether they are continental or diasporant. With a rationale that paid African laborers will produce cotton more economically for the world market than distant African American and African Caribbean slave labor, Delany's plan is for African cotton production (under the encouragement and supervision of African Americans) to make American cotton production - and thereby slavery—obsolete. He argues that such a scheme would

render it impossible for America to compete with Africa in the growth and sale of cotton....Firstly, landed tenure in Africa is free, the occupant selecting as much as he can cultivate, holding it so long as he uses it, but cannot convey it to another; secondly, the people all being free, can be hired at a price less than the interest of

\footnotetext{
${ }^{479}$ Ibid., 293.

${ }^{480}$ Ibid., 351.
} 
the capital invested in land and people to work it - they finding their own food, which is the custom of the country. ${ }^{481}$

Delany invests his scheme with the view of Africans as both cheap labor and, more importantly, an undifferentiated laborer society. "In Africa at present," he states, "[labor] is nine hundred per cent less, being only ten cents or five pence a day for adult labor."482 And that population "will produce the staple cotton, also sugar cane, coffee, rice, and all the tropical staples, with two hundred millions of natives as an industrial element to work this immense domain. The world is challenged to produce the semblance of a parallel to this. It has no rival in fact." ${ }^{, 43}$ What Delany suggests here is a flat African society in which all individuals are merely laborers - no intellects, no owners, no artists, musicians, etc. - and that labor is and can further be limited to agriculture, particularly if the entire continent takes up its natural inclination to produce cotton. Furthermore, his emphasis of the word "natives" through the use of italics not only highlights his class distinction among blacks, but more importantly that he and his fellow emigrationists are not part of that class of laborers of which he writes, but rather, as with all matters African for Delany, managers of the change to be brought to Africa.

When he writes, "By this it will be seen and admitted that the African occupies a much more important place in the social and political element of the world than that which has heretofore been assigned him, ${ }^{, 484}$ Delany seems to suggest that the importance of Africans in the world is cotton, a mentality painfully close to that of plantation owners

\footnotetext{
${ }^{481}$ Ibid., 352.

${ }^{482}$ Ibid., 353.

${ }^{483}$ Ibid., 346.

${ }^{484}$ Ibid., 354.
} 
themselves. Yet Delany argues that wresting control of the production of cotton from those very owners is "our only hope for the regeneration of our race from the curse and corrupting influences of our white American oppressors." ${ }^{485}$ Setting aside any critique of this logic, at stake here is that presumption of Africans as a universal, willing proletariat, the assumption that Africans would "produce it as an indigene in their own-loved native Africa to enrich themselves, and regenerate their race."486 Such a presumption that Africans work cotton to save Africa reiterates Delany's arguments thus far that black race solidarity does not mean black race unanimity. But more important, it aligns Delany's rhetoric of Africa and Africans with precisely the same abolitionist ruminations of the Sierra Leone Company and American Colonization Society, who sought at least in part to undo slavery by removing the productions of slavery from the New World to Africa. Whatever notions Delany may have had of black solidarity, his rhetoric of Africa and Africans is in this regard in explicit solidarity with the historical rhetorical imperialism of Africa that preceded him.

An African American emigration activist who commands such phrases as "white American oppressors" seems strategically poised to overthrow or at least hotly contest whatever rhetorical imperialism was previously enacted on the continent of Africa. Yet, despite his diligent observance and recording of extensive African civil society and its vast economic development, his insistence on an African American interaction with Africa devoid of white influence, and his avoidance of the lexicon of Liberian-era rhetoric of Africa, we find Martin Delany invoking the rhetorics of African inferiority, African heathenism, and African viability for settlement and commerce from the periods

\footnotetext{
${ }^{485}$ Ibid., 298.

${ }^{486}$ Ibid., 355.
} 
of the founding of Sierra Leone and Liberia. That Delany does this in spite of his desire to emigrate to Africa is not an indication of a lack of rhetorical sovereignty but rather that he, as a diasporant, is perhaps not in the position to speak for Africa as much as he is to speak for his diasporant, American identity. That Samuel Crowther arguably shows greater indications of rhetorical sovereignty when describing the Egga area of Yoruba, for example, seems to have to do with traces of remaining identity in Crowther linked to his childhood in the region. Such a disparity between the level of rhetorical sovereignty exhibited by Crowther versus Delany suggests that rhetorical sovereignty in the case of Africa privileges the experiences of where one is from over one's race.

\section{Conclusion: A Sign of Things to Come}

Despite the fact that Delany never returned to Africa nor established the settlement at Abeokuta for which he secured a treaty, ${ }^{487}$ his efforts garnered much attention. He appeared to several whites as willingly doing the work they would prefer to hand off to someone else, a similar and parallel desire of the British temporarily being fulfilled by Crowther and his counterparts. In a letter that Delany prints in the end of Official Report, seemingly as a boast of the public's regard for his expedition, Ralph Clarence of Natal, South Africa makes a request for precisely the kind of industrious African manual laborers described by Delany.

${ }^{487}$ See Blackett, "Martin R. Delany and Robert Cambpell," 22-23; Kass, "Dr. Thomas Hodgkin, Dr. Martin Delany," 388 and 390; Campbell, "Redeeming the Race," 147; and Falola, "Introduction to The Condition, Elevation, Emigration, and Destiny," for details of Delany's return the U.S. and his work during and after the Civil War. 
Assuming that African Americans could come and boss the work of Africans for

little pay, Clarence conflates such economic efforts with Christianizing ones as the means

of saving Africa. He writes to Delany,

I cannot but think, if it were practicable for a few thousands, or even hundreds, of your West Coast men to come round to the East Coast, that is, to Port Natal, an immense amount of good would be derived therefrom; not only in assisting to abolish the barbarous customs of our natives in showing them that labor is honorable for man... What we want is constant and reliable laborers....I have thought that some might work their passage down to the Cape of Good Hope in some of Her Majesty's Men-of-War, and from there they might work their passage in some of the coasting vessels that are continually plying backwards and forwards....[S]hould I not require them myself I will give them such information as may lead them to find good masters. I have always said that Natal is the key to the civilization of South Africa; but, however, there are sometimes two keys to a door, and yours on the West, though a little north of the Line, may be the other; and, by God's blessing, I trust that the nations of the East and West may, before long, meet in Central Africa, not in hostile array, as African nations always have done, but in the bonds of Christian fellowship. ${ }^{488}$

Clarence's use of the term "masters" unavoidably connotes slavery, an undertone only heightened by his request for a trade in reliable workers arriving by regular shipping lanes. However, it is the hint of "hostile" Africans that foretells a shift in the sense of the people and their place: Africa is soon to be dark, and southern Africa is where it will happen.

${ }^{488}$ Qtd. in Delany, The Condition, Elevation, Emigration, and Destiny, 377-78. 


\section{CHAPTER IV: THE SECOND RHETORICAL TURN: THE DARK CONTINENT, INHUMANITY, AND THE PLACE THAT NEVER COULD}

If he went to Africa, the savages would cook him and eat him.

-George Fitzhugh, 1854

I would say colonialism is a wonderful thing. It spread civilization to Africa. Before it they had no written language, no wheel as we know it, no schools, no hospitals, not even normal clothing.

-Ian Smith, Prime Minister of Rhodesia, 1964-1979

In Thomas Richards' 1906 biography Samuel J. Mills Missionary Pathfinder, Pioneer and Promoter, the author writes that on the American Colonization Society (ACS) agent's arrival at the west coast of Africa, "The dream of his life had become real, and his eyes beheld the Dark Continent." Richards then quotes from Mills' journal that classic ACS-era refrain, "Ethiopia shall stretch forth her hand unto God and worship.",489 The juxtaposition of "Dark Continent" and Ethiopia as proxies for Africa is uncanny; for while "Dark Continent" has been identifiable as nomenclature for sub-Saharan, black Africa ever since Henry Morton Stanley included it in the title of his seminal work, its use in reference to Mills's travels sixty years before is utterly anachronistic. According to all available sources, from the O.E.D. and other etymological dictionaries to histories and scholarly discussions, the first appearance of the phrase "Dark Continent" was in Stanley's 1878 Through the Dark Continent, which chronicles his continental crossing

${ }^{489}$ Richards, Samuel J. Mills Missionary Pathfinder, Pioneer and Promoter, 213. 
from Zanzibar to the Congo River estuary. Similarly, the companion phrase "Darkest Africa" appears first in the lexicon for Africa with Stanley's 1890 In Darkest Africa, which reported his rescue mission of a British colonial official displaced from Khartoum. The concept of the continent as dark was immediately accepted and quickly became pervasive,${ }^{490}$ and it continues in wide use today as a common metaphor. ${ }^{491}$ Yet while the typical attribution for first use of the term goes to Stanley, the explanation of its usage as a metaphor is regularly extended to the latter half of the $19^{\text {th }}$ century, the century as a whole, or the Victorian era, ${ }^{492}$ with the term's meaning understood as being a view of Africa as a mysterious and unknown region by those who had yet to explore its interior. Historically, rhetorics of Africa in the $19^{\text {th }}$ century, however, do not in fact align with such a broad, continuous, sweeping generalization. Rather, as it became increasingly apparent that the American colonization scheme in Liberia (like its British precursor Sierra Leone) failed to achieve its intended goals, and while increasing tension within the slavery debates (including increased violence) led to ever more racialist and racist depictions of African Americans and Africans, a rhetoric of an Africa of potential transitioned to a view of Africa as a failed, problematic experiment on the part of the West, a culmination of which included the bloodbath of the American Civil War. In the

\footnotetext{
${ }^{490}$ See, for example, Nature 13 June, 1878, “The Dark Continent," in which Stanley's text is reviewed; furthermore, a brief survey of texts shortly following Stanley's include Jones's 1881 Negroland; or, Light Thrown Upon the Dark Continent; Buel's 1889 Heroes of the Dark Continent; Johnston's 1892 Missionary Landscapes in the Dark Continent; Hotchkiss's 1901 Sketches from the Dark Continent; Naylor's 1905 Daybreak in the Dark Continent; Burlin's 1920 Songs and Tales from the Dark Continent, etc.

${ }^{491}$ Consider the dozen or more articles in the popular press from the last fifteen years that appear at the front of a rudimentary database search, including pieces in Time, The Economist, and Harpers, among many others, or that certain word processing software recognizes the term and attempts to autocorrect it if not capitalized.

${ }^{492}$ For example, see the O.E.D., Webster's, and Wikipedia; see also Jarosz, "Constructing the Dark Continent: Metaphor as Geographic Representation of Africa," 106.
} 
meantime, scientific developments - most specifically Darwin's theories of evolutionenabled further racialist thinking and rhetoric that resituated Africans in the periphery of human development and civilization. These conditions enabled an evolution in the lexicon for describing Africa: given that a prevailing rhetoric of Africa constructed it as a place that had been covered in darkness, it was no great feat to replace the concept of a transitioning Africa—-through Lubbock's notions of social Darwinism ${ }^{493}$ — with an Africa forever mired in a pre-civilized state, not evolving. The shift from darkened to simply dark linguistically was incredibly easy and rhetorically efficient, as underneath the metaphor of darkness and light was the consistent question of Africa's development, (regardless of how it was answered). The current explanation that $19^{\text {th }}$-century writers understood the "Dark" in "Dark Continent" as a representation of their own ignorance of Africa is resisted by the history of $19^{\text {th }}$-century rhetoric which instead suggests the term regressively condemned Africa itself as permanently fixed in ignorance. The Dark Continent construction was not of Africa in a state of ignorance into which it had fallen or from which it might be liberated, but rather that Africa was, had been, and would be permanently ignorant. Even linguistically it would take a logical twist to understand that adjectives modifying the word Africa directly—dark and darkest—would actually be intended to describe not Africa itself, but British and American conceptions of the continent.

This chapter sets out therefore to address two significant contemporary misrepresentations of late- $19^{\text {th }}$-century rhetorics about Africa. The first is the idea that the rhetoric of the Dark Continent and Darkest Africa spanned the $19^{\text {th }}$ century or the

\footnotetext{
${ }^{493}$ See Brantlinger, "Victorians and Africans," 187; Brantlinger's assessment of Lubbock is discussed below.
} 
Victorian era. ${ }^{494}$ The second is the suggestion that this rhetoric referred to a European and American lack of knowledge about the continent. This chapter will argue instead that 1) an altogether different rhetoric of Africa was in place prior to Stanley's first use of the Dark Continent rhetoric in $1878^{495}$ and 2) as this different, preceding rhetoric reveals, the dark depiction of Africa was actually an elaboration of a rhetoric of inherent African inferiority in place since the failure of the Liberia colonization scheme. At stake in such a clarification overall—and with this second and final rhetorical turn in $19^{\text {th }}$-century constructions of Africa - is the specific nature of Stanley's characterization: it is a rhetoric rather than a metaphor and its understood meaning has been altered over time, which has implications for broader theories of rhetorical imperialism and rhetorical sovereignty.

To arrive at these conclusions, this chapter will first consider the evolution in rhetoric about Africa post-Liberia and how it was impacted by Darwin's theories-those rhetorics leading up to Stanley's expeditions. Then, in order to situate Stanley in rhetorics of Africa contemporary for his time and so reveal one of the dominant modes of thinking at the time he framed his famous phrase, attention will be given to the rediscovery of Great Zimbabwe. In this way, the $19^{\text {th }}$-century evolution of rhetoric of Africa can be clearly displayed, as can the accurate nature of the appellation Dark. The rhetorical implications for the ongoing use of "Dark Continent" today can be assessed in terms of function and benefits accrued by those who employ it and the accompanying

\footnotetext{
${ }^{494}$ A seemingly popular, if inaccurate, conflation commonly used in reference to the Dark Continent rhetoric.

${ }^{495}$ We know of at least one prevalent, preceding rhetoric of Africa - the benighted, darkened, degraded Africa. The subsequent shift in rhetoric which led to and perhaps reached its zenith in Stanley (of an Africa patently fixed in savagery, backwardness, and an eternal lesser nature) is what will be explored here.
} 
liability for Africa and the Africans about whom it is used. That such rhetoric endures today, with its construction of Africa as an undeveloped, retrograde place, suggests how rhetorical imperialism might long survive the empire that created it, and the vast and troubling implications for such a scenario. And it further suggests the necessity for examining with much greater scrutiny Western powers' historical rhetoric of Africa, which is really just the history of rhetorical imperialism in Africa (and the final concern in this concluding chapter).

Conventional definitions and usages seem to accept that the term "Dark Continent" means that those of the $19^{\text {th }}$ century felt Africa was an unknown, mostly unexplored mystery. As a result, the rhetoric upon which Stanley's metaphor relies today has been accepted rather than recognized for its rhetorical nature, in spite of the fact that the concept of an unexplored and unknown Africa has been revealed patently untrue in previous chapters here as well as through Stanley's own reference to more than a hundred years of carefully documented exploration. ${ }^{496}$ While those since Stanley may have begun to believe that $19^{\text {th }}$-century Europeans and Americans felt Africa to be unexplored and unknown, we have clearly seen that those living before Stanley (and Stanley himself) would not accept such a characterization.

Recent scholarly interest in the term "Dark Continent" has sought to address both its evolution and its endurance as a means of problematically characterizing Africa. While Hammond and Jablow's oft-cited The Africa That Never Was is interested in broad discourse about Africa since the late-1500s, more recent scholarship has focused on the flashpoint of what Patrick Brantlinger calls the "Myth of the Dark Continent." First to suggest that Stanley's "Dark Continent" phrasing meant something other than that Africa

${ }^{496}$ Stanley, Through the Dark Continent Volume I, 2. 
was unknown to Europeans (or that the phrase simply had a racialized overtone), Brantlinger argues, "The myth of the Dark Continent developed during the transition from the main British campaign against the slave trade, which culminated in the outlawing of slavery in all British territory in 1833, to the imperialist partitioning of Africa which dominated the final quarter of the nineteenth century. ${ }^{, 497}$ He explains further the purpose of the myth, writing, "By mid-century, the success of the antislavery movement, the impact of the great Victorian explorers, and the merger of racist and evolutionary doctrines in the social sciences had combined to give the British public a widely shared view of Africa that demanded imperialization on moral, religious, and scientific grounds." ${ }^{498}$ Brantlinger agrees with Nancy Stepan's framework in The Idea of Race in Science: Great Britain, 1800-1960: “A fundamental question about the history of racism in the first half of the nineteenth century is why it was that, just as the battle against slavery was being won by abolitionists, the war against racism was being lost. The Negro was legally freed by the Emancipation Act of 1833, but in the British mind he was still mentally, morally and physically a slave." ${ }^{499}$

But both Brantlinger and Stepan miss a crucial step in the rhetoric of Africans by moving straight from Abolition in England to racist, mid-century, evolutionary doctrine. Citing Katherine George's claim that Western racism towards Africa took a hiatus when with the "Enlightenment arose new standards of objectivity," ${ }^{1500}$ Brantlinger argues that

\footnotetext{
${ }^{497}$ Brantlinger, "Victorians and Africans," 166.

${ }^{498}$ Ibid., 167-68.

${ }^{499}$ Qtd. in Brantlinger, "Victorians and Africans," 168.

${ }^{500}$ George, "The Civilized West Looks at Primitive Africa, 1400-1800," 62-72. This claim is further supported in Mary Louise Pratt's Imperial Eyes, but also by Siegfried Huigen in "Natural History
} 
"this period of relative objectivity did not end in 1800 but continued well into the nineteenth century." ${ }^{501} \mathrm{He}$ elaborates, stating, "Abolitionist portrayals of Africans as perhaps noble but also innocent or 'simple' savages were patronizing and unintentionally derogatory. Nevertheless, portrayals of Africans between 1800 and the 1830s were often both more positive and more open-minded than those of later years" ${ }^{\text {"502 }}$ Brantlinger's assertion that the rhetoric of the first third of the $19^{\text {th }}$ century was relatively benign and of a different sort from what was to come, however, misses the rhetorical history of Africa, as earlier chapters in this project have revealed. The core of the problem with Brantlinger's argument is that he limits his consideration to British Victorians and utterly ignores that local partner, America, as well as the fact that Stanley, the father of the Dark Continent rhetoric, was himself a British-American hybrid. That said, Brantlinger's focus on Darwinian influences leading to the shift to rhetoric of a dark Africa is essential.

Extending Brantlinger's initial effort, Lucy Jarosz in "Constructing the Dark Continent: Metaphor as Geographic Representation of Africa" also seeks to problematize Stanley's term, in this case not only considering briefly its origins, but also looking at its latter-day repercussions for the continent in two examples, the Kariba Dam project and the AIDS epidemic. One of Jarosz's chief contributions is a greater effort to "reveal the historical persistence and the ideological power of the metaphor" itself. She argues that it

and the Representation of South Africa in the Eighteenth Century," where he challenges Pratt's limitation on that hiatus to the mid- $18^{\text {th }}$ century. Huigen instead cites the writing of late-18th-century Dutch traveler Robert Jacob Gordon: "We have seen that in Gordon's writings the landscape is anything but depopulated, and that the indigenous people are seldom reduced to their corporeality. The "contact zone", the reciprocal contact between colonists and the indigenous population that Pratt asserts was being repressed by the latter half of the eighteenth century, is also not skimped by Gordon. He even seems to have felt a good deal of sympathy with the indigenous population. After his third journey he writes to his benefactor Fagel that people do not essentially differ from each other" (73).

\footnotetext{
${ }^{501}$ Brantlinger, "Victorians and Africans," 173.

${ }^{502}$ Ibid., 170.
} 
"identifies and incorporates an entire continent as Other in a way that reaffirms Western dominance and reveals hostile and racist valuations of Africa and Africans," specifically that construct it "as a negatively valued foil for Western notions of superiority and enlightenment." ${ }^{, 503}$ Jarosz explains that this works through a construction of Africans and Africa "as quintessential objects, ahistorically frozen within a web of dualities such as light/dark, found/lost, life/death, civilized/savage, known/mysterious, tame/wild, and so on, ${ }^{, 504}$ clarifying precisely the nature of the rhetoric of a dark Africa. For although Jarosz is unclear on the precursors to the Dark Continent rhetoric with its ahistorical and dichotomous quality, her clarification of how that late-century rhetoric relies on a notion of a fixed, unchanging Africa locked in some originary nature makes for stark contrast with the early-century rhetorics of a mobile Africa fallen from past glory.

Interestingly Jarosz writes that the metaphor also "counterposes the Dark as sin, ignorance, and brutality with the Light of Christian doctrine and epistemology. Here the Dark Continent does not signify place or person but more a lack of Christian belief and practice, ${ }^{, 05}$ an argument unwittingly in support of the metaphor's heritage from the Liberia-era rhetoric, for such aspects of the rhetoric of Africa were not new to the Dark Continent era. An issue for Jarosz's critique of the historical development of the metaphor is that she relies on Hammond and Jablow for her primary source material, rather than doing broader research herself, with the result that she explicitly focuses on "British colonial commercial, religious, and exploratory initiatives," in particular

${ }^{503}$ Jarosz, "Constructing the Dark Continent: Metaphor as Geographic Representation of Africa," 105.

\footnotetext{
${ }^{504}$ Ibid., 106.

${ }^{505}$ Ibid., 107.
} 
"discourses of explorers, missionaries, and literary authors of nineteenth century

Britain." ${ }^{, 506}$ She therefore both attributes the Dark Continent metaphor to "Victorian origins" and allows herself the extent of "literary authors of nineteenth century Britain" as source material for the Dark Continent.

Being rooted in the span of $19^{\text {th }}$-century Britain allows her to ignore different metaphors of Africa from earlier in the century as well as American sources for metaphors of Africa that might have influenced Stanley. Like Brantlinger, Jarosz disregards the significant interplay across the Atlantic of those interested and involved in Africa, and a key member of that trans-oceanic community was Stanley himself. Only in England until 18 years of age, Stanley left for America, becoming embroiled directly in American race politics for much of the next decade, after which he spent much of the following decade in Africa itself. By the time Stanley penned his famous words, he was not strictly British, and arguably neither was his thinking; limiting the source of the Dark Continent metaphor to British rhetoric is equally problematic. Nonetheless, one of the great strengths of Jarosz's work is to recognize that the Dark Continent is not just a metaphor with an understood meaning, but rather language being put to use to sway and accomplish: she recognizes its rhetorical nature in spite of not having the background or inclination to refer to it as such.

Her concern for the ongoing abuse of the continent through the mechanism of the metaphor is echoed by others, such as Peter Schmidt and Jonathan Waltz, who write of how such scenarios "attract historical archaeologists keen to confront and transform misleading historical representations-representations that, in some cases effectively

${ }^{506}$ Ibid., 105. 
denied cultural and human rights to contemporary Africans. ${ }^{, 507}$ Robbie McLaughlan has also recently written of how "nineteenth-century maps of Africa can be interpreted as the site and scene of imperial wish fulfillment, ${ }^{, 508}$ as he argues for reflexivity in the Metropolitan center resulting from Victorian cartography of Africa, late-19 $9^{\text {th }}$-century explorer-adventurer literature, and Freud's development of psychology. Writing of a late Victorian explorer, McLaughlan states that he "simply glosses over the gaps in empirical understanding with imagined projections and creative conjectures marked by a spurious scientific rigour, a methodology and rhetoric that exemplify how colonial discourse depicted and controlled this blank space on the world map," a space that held the "threatening aura of blankness. ${ }^{, 509}$ McLaughlan is particularly interested in how that gap in British knowledge, particularly in the era of cartography, had psychological impact on the British and how Freud picked up on this in the development of his work. ${ }^{510}$ While McLaughlan is less interested in the historical generation of the rhetoric itself, his work begins the essential consideration of why what remained rhetorically from Stanley's metaphor was primarily an understanding of dark equating with unknown.

Martin Hall in "The Legend of the Lost City: Or, the Man with Golden Balls" further examines mythmaking about Africa through the example of a new archaeologythemed resort in rural South Africa. Outlining what he proposes is a classical colonial representation of historical Africa - "a tripartite skeleton of creation, destruction and

\footnotetext{
${ }^{507}$ Schmidt and Walz, "Re-Representing African Pasts through Historical Archaeology," 63.

${ }^{508}$ McLaughlan, Re-Imagining the 'Dark Continent' in Fin De Siecle Literature, 7.

${ }^{509}$ Ibid., 2.

${ }^{510}$ Referring specifically to Freud's use of the term Dark Continent in his theories on sexuality.
} 
discovery" ${ }^{\prime 11}$ - he argues that the colonial myth accounts for any archaeological site not in the historical record by envisioning first a "Lost Age" founded by a wandering group of non-Africans who create an essentially Edenic peace and unheralded prosperity, only to be broken by the arrival of a "Dark Disaster," typically in the form of barbarous black Africans from the north. This golden age is wiped out, leaving only an "Enchanted Ruin" behind, enough of which "remains to inspire generations of explorers." a trope, however, Hall considers this a "master narrative that structures a cultural politics of Africa." "513 "The world," continues Hall, "only has one role for Africa—as a destiny for other people's expeditions." ${ }^{, 514}$ Perhaps it is Lindy Steibel, who shares Hall's interest in the debates over Great Zimbabwe and how they speak to late- $19^{\text {th }}$-century rhetorics of Africa, who most clearly explains that with Britain's desire for Africa to be brought by explorers "from a vague sense of remote space to its contextualisation in a recognisable place on the map of their imagination" was an underlying sense that "sub-Saharan, darker people were assumed to be savage, literally and morally darker, dwelling in a darkened African interior. ${ }^{" 515}$

While scholars have identified the presence and importance of the Dark Continent rhetoric of Africa as a significant moment (with broad contemporary implications) in the evolution of thinking about and characterizing the continent and its people, they have left open for further exploration the greater rhetoric from which it evolved as well as the

\footnotetext{
${ }^{511}$ Hall, "The Legend of the Lost City: Or, the Man with Golden Balls," 180.

${ }^{512}$ Ibid., 180-81.

${ }^{513}$ Ibid., 181.

${ }^{514}$ Ibid., 198.

${ }^{515}$ Stiebel, “Creating a Landscape of Africa: Baines, Haggard and Great Zimbabwe,” 123, 128.
} 
opportunity to connect it to the rhetoric of Africa already in place at the time, that of Great Zimbabwe. Filling that gap, which is the work of the remainder of this chapter, will serve to contextualize the rhetoric of the Dark Continent in a broader, ongoing, historical rhetoric of Africa that has otherwise been subsumed and so further clarify the nature and embedded meaning in the single most common depiction of Africa today.

I: Rhetoric of Africa after Liberia: Politics, Science, and Unchecked Racism One of the chief questions about the Liberian-era rhetoric of a fallen, benighted Africa is why it did not last. Why, that is, do we not today speak of the Benighted Continent? Because Brantlinger's ongoing analysis of the myth of the Dark Continent is tied up with his focus on literary representation rather than rhetorical analysis of language, his "Genealogy" does not consider the heritage of the adjective "dark" itself. But the pressing issue of why darkened became dark rather than surviving itself must be addressed in order to develop a more accurate interpretation of Stanley's appropriation of the term. And past rhetorical analysis of the precursors of "dark" through a focus on British rhetorics has so far remained incomplete due to the neglect of American rhetorics of Africans and Africa, an omission now to be addressed because it was precisely this American rhetoric in which Stanley was immersed for the decade prior to the start of his life as an explorer of Africa.

At a basic level, part of the demise of the rhetoric of a benighted Africa has to do with the failure of the Liberia scheme itself to meet the goals of those who created it (and most actively promoted its rhetoric). The stated goals for Liberia included the creation of a settlement site for all free and freed African Americans; they also included the broad 
Christianization of the continent through both missionary work and the eradication of African slavery through alternative commerce. That a colony at Cape Mesurado was eventually established and the country of Liberia went independent in 1847 are not indicators of success for the scheme; for the vast majority of free and freed African Americans remained on American soil, African slavery was not abolished, nor was a substantial alternative commercial trade established between Liberia and the U.S. (or elsewhere), and Liberia did not show signs of turning the Continent or even West Africa Christian. These failures inherently devalued the rhetoric that had logically encouraged and convinced the commitments to them: the power of the image of a once fallen Africa just waiting for assistance in order to revive had faded and been replaced by incredulity at such notions. For if anything, the failure of Liberia was a rejection of the notion of African potential and outright called into question that heritage of greatness. Ethiopia of the past was a false legend: she would not stretch out her hand to God (and probably never had). South Carolina physician and racial theorist Josiah C. Nott argued in 1844, "We have no evidence that civilization has ever eminated [sic] from Africa beyond Egypt, and we know that all modern attempts to carry civilization into it have failed,",516 displaying precisely that incredulity.

The 1830 s to the 1860 s in American rhetoric saw a wave of such sentiments in which depictions of Africans and Africa shifted progressively to dehumanizing representations of the people and concepts of the continent as a corrupting place that would bring anyone in it to wretched and taboo forms of existence. The majority of these characterizations, however, were focused on dehumanizing Africans, a logical step for

${ }^{516}$ Nott, "The Natural History of the Caucasian and Negro Races," 219. 
pro-slavery activists who sought to justify the existence of slavery permanently. A brief chronological survey of this rhetoric reveals the trend and its progression, as well as where, in its latter stages, it begins to overlap with developments in evolutionary science.

Soon after Nat Turner's Rebellion, William and Mary law professor Thomas Roderick Dew wrote "Abolition of Negro Slavery," which ran in the American Quarterly Review in late 1832. In it, Dew writes that the "black carries a mark which no time can erase; he forever wears the indelible symbol of his inferior condition; the Ethiopian cannot change his skin, nor the leopard his spots. ${ }^{, 517}$ As an early transitional rhetoric, Dew interestingly indicates a fixed notion of Africans as permanently inferior and does so by invoking the American Colonization Society rhetoric of a regenerating Ethiopia. Not only does Dew reject the notion of a once-great Ethiopia that would return to civilization, but he also animalizes it by equating Ethiopians with leopards, predatory and dangerous. This recasting of Ethiopia both summons the ACS's language and reappropriates it for a foil not just of African potential but more importantly for ACS vision altogether: it is a rejection both of Africa and of those Americans who considered the continent optimistically.

Just a few years later, in 1837, South Carolinian lawyer, politician, and judge William Harper delivered an address to the South Carolina Society for the Advancement of Learning in Columbia. A long examination on civil and human rights at a national level, "Memoir on Slavery" follows in Dew's footsteps by rejecting the Liberian-era notion of an African past with Ethiopian grandeur, instead citing "ancient barbarism." 518

\footnotetext{
${ }^{517}$ Dew, “Abolition of Negro Slavery," 58.

${ }^{518}$ Ibid., 130. Like the Liberian-era characterizations of Africa, where both sides of the slavery debate invoke similar rhetoric, some such moves continue briefly, such as when abolitionist Angelina
} 
But Harper's greater focus is on Africans themselves: "The negro race," he writes, is "inferior to our own in mind and character, marked by inferiority in form and features," whereas "the civilized European man," he argues, is "the most perfect variety of the human race." ${ }^{519}$ Of note is Dew's reference to polygenism, the theory of the time that different human races evolved from different origins, each with their own strengths and limitations, an argument employed often in pursuit of relegating Africans to eternal slavery.

Among the most ardent rhetors in the transition from benighted to simply dark Africa was the group of physicians and scientists who wrote and lectured in promotion of polygenism, including Harvard professor and Cornell lecturer Louis Agassiz, ${ }^{520}$ Egyptologist George Gliddon, physician and author Josiah C. Nott (quoted above), and physical anthropologist Samuel George Morton. Nott in particular was an adherent of Morton and his theories on the correlation between brain size within skulls and intellectual capacity of individual races. Morton's categorization of skull measurements according to four main categories included Africans as the lowest of the four and specified a series of criteria for Africans, which Nott subsequently turned to political ends in the pro-slavery argument. In his pointedly titled 1844 lectures delivered in Mobile, "The Natural History of the Caucasian and Negro Races," ${ }^{, 521}$ Nott explains Morton's

Grimke, in "Appeal to the Christian Women of the South," writes of the difference between being born under American republican government versus "the petty despotisms of barbarian Africa" (112). However, the consistency of this decreases as pro-slavery activists pursue critiques of Africans while abolitionists target notions of freedom for all in the United States.

${ }^{519}$ Ibid., 131.

${ }^{520}$ The power of Agassiz's scientific theories on race (today commonly dismissed as scientific racism) can not be underestimated, given his status at these northern, influential schools. 
craniometry: "There is a marked difference between the heads of the Caucasian and the Negro, and there is a corresponding difference no less marked in their intellectual and moral qualities. ${ }^{, 522}$ This basic premise guides a series of deductions he uses to refute any historical greatness in Africa, any potential for regeneration suggested by the ACS and other colonization or emigration activists (e.g., Delany), and any notions of common, singular ancestry with Africans themselves. "Nature has endowed them," he contends, "with an inferior organization, and all the powers of earth cannot elevate them above their destiny." ${ }^{, 523}$ That destiny according to Nott is a permanent, historically-based state of inferiority:

We can carry back the history of the Negro (though imperfectly) for 4,000 years: we know that he had all the physical characteristics then which he has now, and we have good grounds for believing that he was morally and intellectually the same then as now. One generation does not take up civilization where the last left it and carry it on as does the Caucasian - there it stands immovable; they go as far as instinct extends and no farther. ${ }^{524}$

Morton and Nott contend first and foremost that a physical racial consistency exists, second that such physicality is historically consistent, and third that it is a predictor of the interior of beings, where the biological body is a permanent, stable text. Here Nott again rebukes the Liberian-era rhetorics of a once-civilized Africa now fallen due to the scourge of slavery. Africa in Nott's rhetoric was never civilized and if in a low state, has been in that low state these " 4,000 years."

\footnotetext{
${ }^{521}$ Note plural "Races"; for Nott, this was an essential detail clarifying the distinct, separate racial origins.

${ }^{522}$ Nott, "The Natural History of the Caucasian and Negro Races," 232.

${ }^{523}$ Ibid., 235.

${ }^{524}$ Ibid.
} 
Nott makes, however, not merely a refutation of preceding rhetorics but invokes a phrase newly arriving in American rhetorics of Africans - cannibalism. While occasional references to cannibals dated at least as far back as $16^{\text {th }}$-century Portuguese settlements on the east coast of Africa, ${ }^{525}$ anthropophagy became a trope for depicting Africans and situating them through this taboo practice developmentally lower than "Caucasians." Nott argues,

History cannot designate the time when the Caucasian was a savage. Caucasian races have often been plunged by circumstances into barbarism, but never as far as we know, into savagism. Cannibalism appears to belong exclusively to the African and Oceanic Negroes - the Bushman, the Hottentots, and perhaps the Caribs; but history does not tell us when and where the Caucasian has gorged his appetite on human flesh and blood. ${ }^{526}$

Gone is the African that might be converted to Christianity, that might agree to end the slave trade, or that might become a legitimate trading partner. And gone as well is the Africa that ever bore any hint of greatness. Morton having made craniometric arguments that Egyptians were not black, Nott further dismisses African heritage, ${ }^{527}$ asking, "Where I repeat, except here, will you find from the Mediterranean to the Cape of Good Hope, a single record or a single monument to show that civilization has ever existed? Where are the ruins of her Memphis, her Thebes, her Rome, her Athens or her Carthage. Their intellects are as now as they always have been, as dark as their skins. ${ }^{, 528}$ Nott was

${ }^{525}$ See Huigen, "Travellers to Monomotapa," 208; and Brantlinger, "Victorians and Africans," 184. Brantlinger writes, "As Dorothy Hammond and Alta Jablow note, cannibalism was not an important theme in British writing about Africa before mid-century. But 'in the imperial period writers were far more addicted to tales of cannibalism than ... Africans ever were to cannibalism."”

${ }^{526}$ Nott, "The Natural History of the Caucasian and Negro Races," 235.

${ }^{527}$ In so doing, Nott clarifies a specific rhetoric of ahistorical Africa incapable of constructing lasting monuments or structures, a rhetoric that would be directly invoked twenty-five years later in the (re-) discovery of the Great Zimbabwe ruins and directly lead to Stanley's rhetoric that the continent was eternally "Dark" rather than darkened.

${ }^{528}$ Nott, "The Natural History of the Caucasian and Negro Races," 233. 
widely known at the time, not merely as a follower of Morton, but also as the co-author with Gliddon of the widely-read 1854 tribute to Morton's polygenist work, Types of Mankind, as well as a renowned researcher on Yellow Fever. His conflation of permanently uncivilized, ahistorical Africans with the word "dark" makes for a compelling transition from the rhetorics of the Liberia era as well as a suggestive precursor for Stanley's use of the same term. It also further argues that the contemporary concept of "dark" equating with unknown and unexplored is a fallacy under which is buried crucial rhetoric such as Nott's.

The failure of Africa as an alternative for Africans led several pro-slavery activists, such as leading slavery advocate George Fitzhugh, to contend that slavery served Africans better than any other circumstance they would encounter and that it was in fact in their best interest to be removed from Africa. In his 1854 Sociology for the South, Fitzhugh writes that an African's or African American's “defect of character would alone justify enslaving him, if he is to remain here. In Africa or the West Indies, he would become idolatrous, savage, and cannibal, or be devoured by savages and cannibals.. ${ }^{, 529}$ That Africa itself is such a "dark" place not because it is unknown, but because Fitzhugh conceives of it precisely only reiterates and exaggerates Nott's claims. For it is Fitzhugh, that attorney of Alexandria and immediate neighbor to several of the founders of the ACS, who confidently asserts that if a slave were freed and "went to Africa, the savages would cook him and eat him. ${ }^{, 530}$ It is important to note that Fitzhugh's second and arguably better-known work is his 1857 Cannibals, All! ${ }^{531}$

\footnotetext{
${ }^{529}$ Fitzhugh, Sociology for the South, 132.

${ }^{530}$ Ibid., 134.
} 
Once the language of anthropophagy had been employed and the rejection of an Africa bearing potential was accomplished, American rhetoric of Africans began to invoke some of the developing evolutionary science, such as when lawyer and professor Albert Taylor Bledsoe in his 1857 "Liberty and Slavery" equates "a Hottentot, or an African, or an ape." ${ }^{532}$ E.N. Elliott, editor of the 1860 Cotton is King, expands on Bledsoe's claim when referring to Samuel Cartwright's "Ethnology of the Negro or Prognathous Race," writing that

the negro is now an inferior species, or at least variety of the human race, is well established, and must, we think, be admitted by all. That by himself he has never emerged from barbarism, and even when partly civilized under the control of the white man, he speedily returns to the same state, if emancipated, are now indubitable truths. ${ }^{533}$

These are the rhetorical conditions into which Stanley entered when he arrived in New Orleans in 1859 at the impressionable age of 18.

Unlike these post-Liberia, ante-bellum rhetorics, the accompanying and subsequent rhetorics of evolutionary science on both sides of the Atlantic have been well documented for their depictions of Africa and Africans. ${ }^{534}$ With Darwin's On the Origin of Species and The Descent of Man came the notion of the Great Chain of Being and speculations on an overall hierarchy of beings, from which racial notions of the primacy of Caucasians and inferiority of Africans were already predisposed from the preceding notions of polygenism and craniometry, among others. As a result, Cynthia Russett

${ }^{531}$ Brantlinger chronicles parallel mid-century British rhetorics of cannibalism, such as "Winwood Reade, who in Savage Africa (1863) writes that 'the mob of Dahomey are man-eaters; they have cannibal minds; they have been accustomed to feed on murder"' (184).

${ }^{532}$ Bledsoe, "Liberty and Slavery," 321.

${ }^{533}$ Elliott, Cotton is King, xiii.

${ }^{534}$ See, for example, George Stocking's Victorian Anthropology and John Haller Jr.'s Outcasts from Evolution: Scientific Attitudes of Racial Inferiority, 1859-1900. 
explains, "Scientists sought to stabilize at least one set of relationships and by inserting lesser orders (women, savages) between themselves and the apes, to distance themselves from the animality and erosion of status that Darwinism seemed to imply." 535 Physician and theorist James Hunt, for example, famously left the Ethnological Society and formed his own Anthropological Society of London in 1863 due to his continued belief in polygenism and rejection of Darwinian theories of a single species of humans. ${ }^{536}$ Hunt and others suggested that Africans might be the missing link between the primates and civilized Europe. Brantlinger reiterates this, suggesting that while Thomas Huxley's 1863 "Man's Place in Nature"

involves a refutation of the idea that Africans, Australians, or other primitive peoples are the "missing link" or evolutionary stage between the anthropoid apes and civilized (white) mankind,

John Lubbock seems to counter Huxley when in his 1870 The Origin of Civilisation and the Primitive Condition of Man he argues,

Not just that contemporary "savages" represent the starting point of social evolution but that they are below that starting point. The original primitives from whom Europeans evolved contained the seeds of progress; modern savages had not progressed, according to Lubbock, and hence must be lower on the evolutionary scale than the ancestors of the Europeans. ${ }^{537}$

While both Huxley and Lubbock argued for a view of Africans that suggested they could evolve (as opposed to Hunt's fixed view), they nonetheless situated Africans beneath all others, which is a continued rejection of a once great or civilized Ethiopia. Whatever Africans might (or might not) have it in them to do, they had not—up to this point—-done

\footnotetext{
${ }^{535}$ Russett, Sexual Science, 14.

${ }^{536}$ See Russett, Sexual Science, 26-27; and Brantlinger, "Genealogy of the Myth of the Dark Continent," 182.

${ }^{537}$ Brantlinger, "Victorians and Africans," 184.
} 
it. However Brantlinger might have skipped over the step of the Liberian-era rhetorical precursors of an African benightedness, he aptly concludes that "Victorian Africa emerged draped in that pall of darkness that the Victorians themselves accepted as reality, ${ }^{, 538}$ particularly if that Victorian umbrella in this case extends to mid-to-late-1 $19^{\text {th }}$ century America.

II. The Africa That Never Could: Dark Continent Rhetorics and Great Zimbabwe The task of this chapter is to interrogate the presence of the "Dark Continent" in Henry Morton Stanley's writing about Africa, and to attempt to interrogate the intent in his usage of the term. It is also to situate Stanley in broader late- $19^{\text {th }}$-century debates about the nature of Africa and Africans with regard to Great Zimbabwe that might give insight into both his seeming creation of the term "Dark Continent" and the speed of its acceptance. What brought Stanley to the international stage was the report of his successful location of Scottish missionary David Livingstone in November 1871. As they explored together for some time before Stanley returned to the coast, and as he published his first, immensely successful book How I Found Livingstone in Central Africa, it might be deduced that the elder missionary-explorer served as somewhat of an inspiration for the younger journalist, or might even have inspired certainly terminology for Africa. However, not only does Stanley refute such a notion, claiming that he "cared not one jot or tittle about his discoveries, except so far as it concerned the newspaper which commissioned me for the 'search,", ${ }^{339}$ but a close examination of Livingstone's own publications reveals that he had no such specific terminology of Africa to lend to

\footnotetext{
${ }^{538}$ Ibid., 198.

${ }^{539}$ Stanley, How I Found Livingstone, 489.
} 
Stanley. At no point does Livingstone in his Narrative of an Expedition to the Zambesi or The Last Journals of David Livingstone, in Central Africa refer to Africa as the Dark Continent, nor use any synonym for darkness in reference to the continent or its people. Rather when the word appears, it is in reference to shade within forested sections of the landscape.

Stanley's own prose in "his first bestseller," ${ }^{540}$ How I Found Livingstone also is barren of the phrase "Dark Continent." Its single reference to darkness not having to do with an absence of physical daylight is found in his eulogy to Livingstone:

With every foot of new ground he travelled over he forged a chain of sympathy which should hereafter bind the Christian nations in bonds of love and charity to the Heathen of the African tropics. If he were able to complete this chain of love - by actual discovery and description of them to embody such peoples and nations as still live in darkness, so as to attract the good and charitable of his own land to bestir themselves for their redemption and salvation - this, Livingstone would consider an ample reward. ${ }^{541}$

For Stanley, Livingstone and his rhetoric of those "still in darkness" (the "still" indicating that the state is not permanent) represented an older generation, one that clung to notions of charitable salvation of Africans and regeneration of the continent. It is when Stanley has duly discovered and then textually buried the now-deceased Livingstone that he returns to Africa to set right what problems remained with the continent.

For Stanley, a next-generation product of the poorhouses of Britain and the racialized conflagration of the Civil War (of which he was a combat veteran of both sides), a return to Africa was neither about redeeming Africans nor Christianizing Africa.

\footnotetext{
${ }^{540}$ Brantlinger, "Victorians and Africans," 176. Brantlinger continues, "Stanley's other books were also best-sellers: In Darkest Africa, for example, sold one hundred and fifty thousand copies in English, was frequently translated, and, according to one reviewer, "has been read more universally and with deeper interest than any other publication of' $1890 . "$

${ }^{541}$ Stanley, How I Found Livingstone, 490.
} 
It was instead to be "perilous labors" and "months of fighting for so dear life among cannibals and cataracts," hoping to rectify the fact that Livingstone "had died by the shores of Lake Bemba, on the threshold of the dark region he had wished to explore!"542 Here begins Stanley's rhetoric of "dark"; however, it is immediately more complicated than those contemporary definitions of the Dark Continent. For while Stanley specifically refers to a geographic issue, it is merely one "region" of the continent, not the continent as a whole, and the frustration is that it is the single remaining portion of the entire continent that according to Stanley and his financiers remains unexplored. The problem with this "dark region" is precisely the fact that the rest of the continent has in fact already been brought to light, which is to say brought into British and American certainty.

Explaining that he "knew what had been accomplished by African Explorers, and...how much of the dark interior was still unknown to the world," he specifies the latter precisely to the editor of the Daily Telegraph (his co-financier with Bennett of the New York Herald): "The outlet of Lake Tanganika is undiscovered. We known nothing scarcely[sic] —except what Speke has sketched out—of Lake Victoria; we do not even know whether it consists of one or many lakes, and therefore the sources of the Nile are still unknown. Moreover, the western half of the African continent is still a white blank." ${ }^{, 543}$ The Daily Telegraph explained that Stanley's expedition was "to solve, if

\footnotetext{
${ }^{542}$ Stanley, Through the Dark Continent, Volume I, vii, ix, 1.

${ }^{543}$ Ibid., 2. The "white blank" here refers to Stanley's imaginary space left open on the map of mid-coast Africa south of the Bight of Benin. In fact, the map he worked from was a 1676 Portuguese map of precisely the region he suggested he would clarify. Over the course of twelve pages (11-21), Stanley represents the cartographic evolution from that 1676 map to his own 1877 update, a process in which first the Portuguese markings are erased and then the lines progressively re-drawn over the course of Livingstone, Speke, Burton, and Stanley's collective effort. That the original bears striking similarity to Stanley's final version further indicates what it meant for a region to be unexplored and dark. It must, by
} 
possible, the remaining problems of the geography of Central Africa; and to investigate and report on the haunts of the slave traders...He will represent the two nations whose common interest in the regeneration of Africa was so well illustrated when the lost English explorer was rediscovered by the energetic American correspondent." ${ }^{454}$ Demonstrating the cross-Atlantic nature of rhetoric of Africa, Stanley interestingly chooses to quote this passage from the British paper in which he is designated an American.

Stanley further indicates his tension between the previous, missionary ways of characterizing the outsider's relation to Africa (i.e., Livingstone's) and his own, which are more loyal to the adventurer mystique of Mungo Park and the long-gone African Association. When he quotes the Daily Telegraph further - that "it may be hoped that very important results will accrue from this undertaking to the advantage of science, humanity, and civilization" ${ }^{545}$ - he attributes such old desires to the paper itself rather than stating them as his own (having repudiated such goals at the end of his prior book).

In a span of more than 800 pages, Stanley only employs the term "Dark Continent" approximately six times, and the terms "dark" or "darkness" little more. Typically he invokes the phrase by itself without explaining it. He only comes close to clarifying its purpose specifically one time, early in the expedition, when he at last sets sail from the island of Zanzibar for the eastern coast of the continent:

The parting is over! We have said our last words for years, perhaps for ever, to kindly men! The sun sinks fast to the western horizon, and gloomy is the twilight

Stanley's standards, have been explored, surveyed, and recorded by Northern Europeans or Americans, a clarification that usefully explains why the Portuguese discovery of Great Zimbabwe in the $16^{\text {th }}$ century did not count, and the ruins had to be re-discovered by Karl Mauch in 1871 .

\footnotetext{
${ }^{544}$ Qtd. in Stanley, Through the Dark Continent, Volume I, 3.

${ }^{545}$ Ibid.
} 
that now deepens and darkens. Thick shadows fall upon the distant land and over the silent sea, and oppress our throbbing, regretful hearts, as we glide away through the dying light towards the Dark Continent. ${ }^{546}$

His capitalization indicates that he does not merely mean it is physically dark due to nightfall, but imbued with a greater meaning. A few nights earlier, after first arriving on Zanzibar, he waxed poetic in a similar fashion, perhaps predicating that meaning alluded to in the above passage:

As little as his eyes can pierce and define the details in that gloomy streak on the horizon, so little can he tell whether weal or woe lies before him. The whole is buried in mystery, over which he ponders, certain of nothing but the uncertainty of life. Yet will he learn to sketch out a comparison between what he sees at sunset and his own future. Dark, indeed, is the gloom of this fast-coming night over the continent, but does he not see that there are still bright flushes of colour, and rosy bars, and crimson tints, amidst what otherwise would be universal blackness? And may he not therefore say_- "As those colours now brighten the darkening west, so my hopes brighten my dark future"? ${ }^{547}$

The foreboding of the "throbbing, regretful hearts" in the "gloomy" night of departure seem to coincide with "the uncertainty of life," of "his own future." The "universal blackness" seems to indicate that unclear future - a "dark future" because of its "uncertain" fate - to which Stanley is destined; the "flushes of colour, and rosy bars, and crimson tints," his optimism.

Stanley's metaphor of the Dark Continent has to do with the daring explorer risking all in hopes of achieving a glorious fate, a sentiment only further clarified when in Volume II, just before setting off on the Congo River first descent, ${ }^{548}$ he writes that "the object of the desperate journey is to flash a torch of light across the western half of the

${ }^{546}$ Stanley, Through the Dark Continent, Volume I, 54.

${ }^{547}$ Ibid., 29-30.

${ }^{548}$ This is the latter part of his expedition, following his successful completion of surveying the lakes, which made up the first two "mysteries" he set out to resolve. 
Dark Continent."549 Here, at the moment of perhaps his greatest daring — other than simply setting out in the first place-Stanley invokes the Dark Continent phrasing once again, this time seemingly using it as a device simply to enhance the drama, for it is a "desperate journey." Suggesting that clarifying a two-hundred-year-old Portuguese map was an act of desperation is the sort of literary license for which Stanley became a celebrity of his time, but it also reveals that he is a writer of literary license and hyperbole, a significant insight when considering his use of the Dark Continent and its intended meaning.

Of chief importance to this chapter is that Stanley's depictions of Africans demonstrate that like all writers, he was a product of those who had preceded him. Occasionally referring to his employees on the expedition as "my dark followers,",550 where dark simply depicts their complexion, he also describes Africans as "natives," “cannibals," "human beasts of prey," "negro," as well as those with "willing hands and...loyal hearts," and "ignorant children of Africa." 551 When passing through WaneKirumbu, in Uregga, he writes of a smithy operation, noting that "from one generation to another, something has been communicated and learned, showing that even the jungle man is a progressive and an improvable animal." ${ }^{, 52}$ That this is just two pages before he refers to other Africans as "cannibals" indicates how Stanley invokes those more optimistic historical rhetorics of Africans (children, noble potential) alternatively with the

\footnotetext{
${ }^{549}$ Stanley, Through the Dark Continent, Volume II, 99.

${ }^{550}$ Ibid., 281, 315; also see Volume I where he writes, "The dark brother, wild as a colt, chafing, restless, ferociously impulsive, superstitiously timid, liable to furious demonstrations, suspicious and unreasonable, must be forgiven seventy times seven, until the period of probation is passed" (56).

${ }^{551}$ Stanley, Through the Dark Continent, Volume II, 39, 113, 361, 371, 374, 373.

552 Ibid., 111.
} 
more recent, harshly racist ones (animalistic, cannibal), in between including specific depictions of people with whom he had worked. That he invokes these familiar terms (both old and new) for Africans suggests that his depiction of Africa is also an act of invoking that which came before - that "Dark" Africa is an inheritance from Clay and Mill's “benighted” Africa.

With the Dark Continent metaphor, Stanley is not suggesting that the continent is unknown, but that it is risky - the explorer cannot know what will happen there, a fact Stanley knew from personal experience as well as from having read the explorers' library on Africa. ${ }^{553}$ In Through the Dark Continent, he is utterly clear on the fact that Africa is already mostly known and that his proposed goal (and subsequently great accomplishment) is to clarify what remained vague. His 800 -page travelogue provided an incredible amount of specific information, such that Africa remained anything but unknown. Yet immediately upon the publication of his book, which actually clarifies Africa and in dramatic fashion highlights the impressive nature of his quest, rather than praising that clarity, literary society instead re-appropriates his terminology and focuses on the mystery with which he started.

Not to do so would allow Africa to cease serving as the universal Other ${ }^{554}$ - the unknown which served as a foil to the West (which was rational, enlightened, gaining certainty all the time through its science and reason). Arguably the Dark Continent could

553 "It lead me to purchase quite an extensive library of books upon Africa, its geography, geology, botany, and ethnology. I thus became possessed of over one hundred and thirty books upon Africa, which I studied with the zeal of one who had a living interest in the subject, and with the understanding of one who had been already four times on the continent. I knew what had been accomplished by African Explorers, and I knew how much of the dark interior was still unknown to the world" (Stanley, Through the Dark Continent, Volume I, 2).

${ }^{554}$ Of which Jarosz, among others, writes: see, for example, 105-06, 108, 112-13. 
not be allowed to refer metaphorically to the risk of the explorer, when it could instead maintain a distance with Africa that would continue to refute common human ground with Africans. Rather, Africa needed to remain unknown in order to maintain the West's identity of itself as superior, as agent, as ruler, as consumer. No moment in the exploration of Africa more resoundingly clarifies this than the explorers' debates over Great Zimbabwe, debates that raged at precisely the same time as Stanley's explorations (he in fact refers to them ${ }^{555}$ ) and that reveal why Stanley's intent to dramatize his text was subsumed by greater cultural, political, and economic needs to keep Africa mysterious and unknown rather than to allow it, against all the facts, to assume a place of equal status with the West.

When in 1871 German explorer Karl Mauch encountered a large stonework complex in what is now southeastern Zimbabwe, his find shattered the same preconceived incredulity at the possibility of African monuments voiced by Josiah Nott twenty-seven years earlier. For here was a grand structure with intricate mortar-free stonework of conical multi-story buildings intertwined with five-meter high, doublelayered barricade walls, in a state of abandonment (the word "zimbabwe" is generally translated as "great house of stone"). The decay and disuse indicated that the stone structures were not of recent construction, but their purpose, the meaning of the patterned designs woven into the architecture, and the identity of their builders was unknown.

555 “'Mono-Matapa,' that great African word, which, from its antiquity and its persistent appearance on our maps - occupying various positions to suit the vagaries of various cartographers and the hypotheses of various learned travellers - has now become almost classic, bears a distant relation to the tribe of the Watuta....Zimbaoa, the capital of this interesting land, was said to be fifteen days' travel west from Sofala, and forty days' travel from Sena. Indefatigable and patient exploration by various intelligent travellers has now enabled us to understand exactly the meaning of the various names with which early geographers confused us" (Through the Dark Continent, Volume I, 393-94). 
Mauch's report was quickly published, translated, and disseminated across Europe ${ }^{556}$ and equally as quickly, the unmistakable record of sophisticated civilization that the stone structures presented was attributed to a source other than black Africans. One of the first to popularize the idea of a foreign builder of the ruins was explorer and painter Thomas Baines, who created the "Map of the Gold Fields of South Eastern Africa," with specific pinpointing of the "Supposed Realm of the Queen of Sheba." At the same time, Baines painted what became a popular vista of the region entitled the "Land of Ophir." ${ }^{557}$ At the heart of the reports coming out of upper Southern Africa was the identification of King Solomon's city of gold, constructed by the Phoenicians. "Since the last century," explains Scott Carroll, "a debate has ensued with the publication of rival theories to explain the origin of the ruins. The various arguments that have been put forth can be categorized into two groups: those who maintain that the walls were the work of indigenous Africans (the Bantu) and those who argue that the structures were built by foreigners, ${ }^{558}$ with those two factions categorized by David Chanaiwa as "indigenists" and "diffusionists," respectively. ${ }^{559}$ The scholarly debate has grown so extensive and is filled with enough political (and, as will be argued, rhetorical) intrigue that a sub-field of historiography of the debate itself has formed with new contributions ongoing at both levels. ${ }^{560}$

\footnotetext{
${ }^{556}$ Carroll, "Solomonic Legend: The Muslims and the Great Zimbabwe," 237.

${ }^{557}$ Qtd. in Stiebel, “Creating a Landscape of Africa,” 123, 125.

${ }^{558}$ Carroll, "Solomonic Legend: The Muslims and the Great Zimbabwe," 233.

${ }^{559}$ Chanaiwa, The Zimbabwe Controversy: A Case of Colonial Historiography, 3.

${ }^{560}$ For further contributions to the debate over origins, see Balsan, "Ancient Gold Routes of the Monomotapa Kingdom"; Bisson, "Trade and Tribute: Archaeological Evidence for the Origin of States in
} 
Perhaps most significant is the way the debate was quickly appropriated for political and economic purposes. Daniel Tangri explains that

Cecil Rhodes perceived the political value of Great Zimbabwe....It was easy enough to suggest that the ancient grandeur of Rhodesia had been overrun by invading Bantu. Colonization of Rhodesia, and subjugation of the Bantu, could be justified on the grounds that the British were repatriating former "white" territory and re-establishing civilization there. In this case it was clearly in Rhodes' interests to develop a picture of Great Zimbabwe, probably the site of some former power in the region, as a thriving Phoenician center. ${ }^{561}$

Rider Haggard, author of King Solomon's Mines and She, both of which share Ophir-like settings in southern Africa, was a friend and collaborator with Rhodes on Great Zimbabwe. Incorporating legends of the Phoenician settlement of Britain, Haggard further argued that "the British were the heirs of the Phoenicians in southern Africa, and Great Zimbabwe was 'the heritage of the Anglo-Saxon race." ${ }^{\circ 62}$ And Rhodes and his British South Africa Company sponsored several archaeological teams to research the ruins and find the evidence necessary to justify the Phoenician argument. ${ }^{563}$

It was not until 1906 that David Randall-MacIver published the first indigenist argument. Before that time, all of the writings and theorizing about Great Zimbabwe

South Central Africa"; Chanaiwa, "Politics and Long-Distance Trade in the Mwene Mutapa Empire during the Sixteenth Century"; Chennell, "Great Zimbabwe in Rhodesian Fiction"; Chrisman, "The Imperial Unconscious? Representations of Imperial Discourse"; Ficke, "The Source of Rider Haggard's 'She",; Fontein, The Silence of Great Zimbabwe: Contested Landscapes and the Power of Heritage; Hall and Vogel, "Some Recent Radiocarbon Dates from Southern Africa"; Huigen, "Travellers to Monomotapa: The Representation of Southern Africa by the Dutch in the Seventeenth Century" as well as "Natural History and the Representation of South Africa in the Eighteenth Century"; McNaughton, "A Possible Semitic Origin for Ancient Zimbabwe"; Schmidt and Walz, "Re-Representing African Pasts through Historical Archaeology"; and Tangri, "Popular Fiction and the Zimbabwe Controversy." Among the historiographies are David Chanaiwa, The Zimbabwe Controversy; Hull, "The Legend of the Lost City: Or, the Man with Golden Balls"; and David Leaver, "Great Zimbabwe: Colonial Historiography."

\footnotetext{
${ }^{561}$ Tangri, "Popular Fiction and the Zimbabwe Controversy," 295.

${ }^{562}$ Ibid., 296.

${ }^{563}$ Ibid., 295-96. As Tangri and others have documented, Rhodes promoted diffusionist findings and suppressed indigenist ones, funding both sides along the way.
} 
share one common factor: the impossibility of local construction. Not surprisingly, the rhetoric of Great Zimbabwe echoed that of the broader rhetoric of Africans and Africa arising from the post-Liberia era. The same rhetoric of Josiah Nott that rejected the possibility of any African monuments or any civilization at any point in the last 4,000 years, or that of Lubbock and Huxley that situated Africans distantly beneath the civilized people of Europe and America, framed the way Mauch, Baines, Rhodes, Haggard, and archeologist Theodore Bent and researcher Alexander Wilmot perceived and reacted to the unparalleled ruins. As Bent's and Wilmot's writings reveal, the rhetoric of an Africa forever frozen in inferiority and savagery, without development or potential for progress (as opposed to the temporarily benighted Africa), was precisely the rhetoric the first explorers of Great Zimbabwe invoked and repeated. They too envisioned an Africa that was not briefly darkened or benighted, but rather an utterly dark Africa devoid of the potential in ancient or modern times of constructing anything of the grandeur of Great Zimbabwe.

Bent spends most of the time in his 1893 article "On the Finds at the Great Zimbabwe (With a View to Elucidating the Origin of the Race that Built Them)" explaining how the ruins and their artifacts mirror similar structures and items thought to be of Phoenician origin in and around the Mediterranean. He dismisses African origins swiftly: "Firstly, the ruins and the things in them are not in any way connected with any known African race. ${ }^{, 564}$ Seeing no reason to justify such a claim, he instead focuses his work on proposing the Phoenician origin, such as when he writes, "In Lucian's description of a temple at Hierapolis, near the Euphrates, in his work De Syria dea, we have much that is in accord with these temples at Zimbabwe, the double walls, the sacred

${ }^{564}$ Bent, "On the Finds at the Great Zimbabwe," 132. 
enclosure, the peculiar nature and structure of the tower."565 Again looking for Phoenician parallels, he observes a structure mirroring Phoenician stone worship and suggests the findings are "all pointing to the fact that the ancient inhabitants of these ruins, whenever they found a curious formed stone, brought it here and put it on the platform, where they kept all their revered stones-a spot which would compare well with the...Bethel of the Phoenicians, closely akin to the Southern Arabians." ${ }^{, 566}$ Referring to the design on a soapstone bowl found at the ruins, Bent continues: "This alone is sufficient to prove the foreign element of the builders of the ruins, and that they came from more northern climes, as is also evidenced by the fact that for the town and fortress they chose the southern or shady side of the hill, whereas the Kaffirs always prefer the sunny side. $" 567$ Bent concludes,

The cumulative evidence in favour of this race being one of the many tribes of Arabia is very strong. The special cult, the monolithic decorations, and the later evidence of Arabian intercourse with this country when their power was reduced only to the coast line. Furthermore, we know that the Red Sea was bristling with activity centuries prior to our epoch; that Arab ships brought spices from India, the cassia tree from China; and the wealth of Arabia in those days was proverbial. The Bible is full of allusions to it, the monuments of Egypt bear equal testimony to the wealth of the people of Punt. ${ }^{568}$

And so the great length and breadth of Bent's work is to find the material artifacts that support his preconceived conclusion that Africans did not build the Zimbabwe.

So certain is he that African construction is not a possibility that Bent configures his exploration of the site disregarding Africans entirely: thus he frames the dilemma as

\footnotetext{
${ }^{565}$ Ibid., 125.

${ }^{566}$ Ibid., 128.

${ }^{567}$ Ibid., 129.

${ }^{568}$ Ibid., 132.
} 
having to do with which foreign group actually built the site. For example, he writes, "It is impossible that a collection of things such as there could be brought together here by any but a highly commercial race like the Arabians were, or their kinsmen of Phoenicia. ${ }^{„ 569}$ He makes short work, on the other hand, of the Africans, stating simply that the artifacts found are "above the capabilities of modern Kaffirs, and tools, chisels, and adze, and spades, all pointing to a higher state of civilisation. ${ }^{, 570}$ Bent's disregard of Africans' potential and African history is entirely aligned with the rhetorics of Africa and Africans preceding him for decades, and so it is no surprise that he too invokes a simple dismissal of the continent and its people, who in his mind continue to live in the dark in which they have always lived, watching as others come and go building massive stone civil structures along the way. Africa in Bent's rhetoric, like that of his predecessors as well as his contemporary Stanley, is a recipient for non-African intent, lacking any volition, agency, or potential of its own.

Alexander Wilmot, compatriot to Bent and Rhodes, sought in his 1896 work Monomotapa to support Bent's archaeology with archival textual support for a Phoenician origin. Operating under the same premises of Bent, Wilmot sought not to discredit Africans, for that went without saying, but to find the evidence that would support one foreign settler over another. ${ }^{571}$ Haggard, in the introduction to Wilmot's work, clarifies the utterly familiar ahistorical sense of Africa the three of them shared:

Southern and Central Africa has been named the country without a past. Till within recent years its untravelled expanses were supposed from the beginning to

${ }^{569}$ Ibid., 130.

${ }^{570}$ Ibid., 131.

${ }^{571}$ The early debates over Great Zimbabwe differed from the modern ones in that the early ones ignored African potential outright, whereas the modern ones pit African against foreign construction. 
have harboured nothing but wild beasts and black men almost as wild, who for ages without number had pursued their path of destruction as they rolled southward from the human reservoir of the north, each wave of them submerging that which preceded it. ${ }^{572}$

Here is the dark Africa, eternally fixed in its brutal savagery, unchanging and unproductive. Ironically, what Haggard suggests has been harboured is not anything that mediates this ahistorical, savage Africa, but rather some brief visitors from elsewhere who came into the continent briefly to build something superb and then left - the builders of Great Zimbabwe were literally "harboured" in Africa, but were not and did not become of it.

Wilmot favors Bent's claims, supporting them by elaborating on Bent's findings with further information from findings on Phoenicians. For example, Wilmot performs precisely such a move when he explains, "Mr. Bent proves that these buildings were erected by people who practiced the nature worship of Phoenicia....the birds (vultures or hawks) represent Astarte, the female element in creation, and there are rosettes (emblems of the sun) used in the same way as on the Phoenician sepulchral stelae in the British Museum."573 Wilmot quotes Bent directly, writing that "eastern Africa was an 'Ophir;' and he adds that, in his opinion, 'The cumulative evidence is greatly in favor of the golddiggers being of Arabian origin, before the Sabaeo-Himyaritic period.",574 What we learn from these details is Wilmot's conclusion: "Knowing that the Zimbabwe forts of Southeastern Africa were erected by a Phoenician people, one question which naturally

\footnotetext{
${ }^{572}$ Haggard, "Introduction,” xiii.

${ }^{573}$ Wilmot, Monomotapa, 5-6.

574 Ibid., 9.
} 
arises is, What was their original form?",575 Like Bent, Wilmot is quick to dismiss any relevance of the African presence in the ruin's history. Indeed, to that end he states that "it does not seem either that the materials of the forts were ever required by nations who made huts their dwelling places," framing one form of architecture as mutually exclusive of another.

This is a reiteration of the latter- $19^{\text {th }}$-century rhetoric of Africa binaries: hut/zimbabwe is a parallel to dark/light, civil/savage, and other extreme oppositions that remind us Wilmot is situated in these rhetorics of Africa rather than the Liberia-era ones (which saw a more flexible, fluid possibility for Africa to move in and out of civil advancement and greatness) or Sierra Leone-era rhetorics (which, while tinged with some condescension, were far less specific or consistent in the way they constructed Africans and Africa). Wilmot, on the other hand, sees that

Everything around is dark, and the mere distant and uncertain glimmerings of light which we can perceive may frequently lead us in a wrong direction. The greatest indulgence, therefore, is justly due to an effort of exploration in a comparatively new direction, regarding, as it does, so difficult a problem as the partial solution of the questions raised in the discovery of the African Sphynxes of the modern world. ${ }^{577}$

For Great Zimbabwe is a problem not of an undiscovered mysterious Africa, but of something out of its place by being in Africa; and Africa itself offers no assistance in discerning the mystery the "Sphynxes"-or zimbabwes_-present. That "dark" which poetically surrounds everything is Africa, a hindrance in its "absence of any record" that creates work "necessarily of an eminently unsatisfactory character, as it merely represents

\footnotetext{
${ }^{575}$ Ibid., 9-10

${ }^{576}$ Ibid., 10.

${ }^{577}$ Ibid., 120.
} 
a species of groping after truth. ${ }^{, 578}$ Dark Africa is that which must be worked around in order to achieve one's own goals, whether they lie with or without it, something even the honored descendents of the creators of Great Zimbabwe were, according to Wilmot in his final historical analysis, unable to do, for they were consumed, literally, by cannibal hordes from the north. ${ }^{579}$

Close analysis reveals that buried underneath the notion of an unknown, unexplored Dark Continent is the heritage of a known, dark, savage Africa, a heritage that continues to actively reproduce the continent as a racialized Other there for the ongoing purpose of other people's projects. Lucy Jarosz writes that the metaphor of the

\section{Dark Continent}

homogenizes and flattens places and people, denies the actualities and specificities of social and economic processes which transform the continent, and obscures a nuanced examination of the forces of cultural and economic imperialism unfolding within Africa in their relation to Europe and America. Thus, the metaphor legitimates the status quo and perpetuates unequal relations of power. $^{580}$

If we look to the history of rhetoric about Africa-rhetoric achieved in a clearly delineated path from Enlightenment-influenced considerations of the fundamental similarity of all people to increasingly disparaging rhetorics that were employed in order to have Africa perform the purpose most needed of it by outsiders - we begin to exhume the act of rhetorical imperialism in its entirety, in the process gaining a more accurate sense of its nature and its borders so a more effective pursuit of its antidote of rhetorical sovereignty can be mounted.

\footnotetext{
${ }^{578}$ Ibid.

${ }^{579}$ Ibid., 213.

${ }^{580}$ Jarosz, "Constructing the Dark Continent: Metaphor as Geographic Representation of Africa," 105 .
} 
If, on the other hand, we leave the rhetoric of the Dark Continent intact, swallowing the masquerade that a century ago outsiders were ignorant of Africa, we too consume a conveniently false series of sensibilities of Africa: that it is the place unlike the rest of the global community, having pockets and edges that remain unknown; that it bears a darkness that equates with grimness, for darkness is not a question mark, but a depiction denoted with foreboding of tragic eventualities; that it somehow continues to be a place where things that should not happen are obscured from the light, where old taboos such as cannibalism are continued in new taboos such as habitual genocide. Yet rhetoric is performative as well as purposeful. And so one remaining question is to whose benefit it is to continue what are now age-old rhetorics of Africa and what precisely is being gained by such ongoing performance. One means towards rhetorical sovereignty for Africa itself must be a more complete knowledge of the path rhetorical imperialism took so to know precisely where to start dismantling its residue. 


\section{CONCLUSION}

To the extent that the analysis in this dissertation has proposed moments of rhetoric during the period of exploration and discovery of Africa, it equally indicates the depth and breadth of work that remains to be done. Certainly the question of whether or not Britain and the U.S. have operated imperiously with their rhetorics of Africa seems to be resolved, at least to the extent of pushing the history of such imperialism further back than the late-1800s rhetoric of the Dark Continent. Rhetorical trends about Africawhether directly related to the Dark Continent or not - are strongly indicated. And even if some of those trends seem to be expressed more ambivalently than the hostility implied by the use of the term imperialism, there nonetheless appears to be a repeated desire among British and American writers to construct a version of Africa based on their own

first impressions or those of preceding European explorers rather than through retrieving information from Africans.

It is difficult to imagine, for example, Africans themselves referring to Africa as benighted or as the Dark Continent (at least not without a sense of irony today). Equally it is difficult to imagine them in 1785 describing themselves primarily as viable and promising receptacles for British intention. And while various historical African leaders have been quoted in this project as saying they are interested in learning what the white men have to share, it nonetheless seems difficult to imagine that they would choose to make a habit of describing themselves primarily with the adjective "inferior." Above all 
else, they would in all likeliness not have referred to themselves as Africans, not at least until they were hailed as such by the British and Americans who descended upon them. In short, the terms and characterizations so familiarly used about Africans have been resoundingly supplied for the Africans rather than inquiring of them what terminology they themselves would supply. To the extent that such British and American supply—a pretty word for the imperialism it in fact was—existed in 1785 or 1817 or 1878, the contemporary examples discussed in this text, from popular Hollywood films such as 2012 to the purportedly more intellectualized BBC series Africa: Eye to Eye with the Unknown reveal that the taking hold and defining of Africa from the outside continues to be a common practice in spite of whatever contestations have occurred along the way, even since the end of colonialism. It seems that despite departing more or less from the land, Britain and America continue to be particularly interested in constructing their own versions of Africa as much as they are in oil rights, and thus the rhetorical imperialism that pre-dated colonialism—or accompanied it as one of its chief tools—-has outlasted colonialism itself. A measure of the power of rhetorical imperialism may very well be the apparent endurance of the terms employed to contain an empire as well as the endurance of the act of maintaining control over those terms, both of which could, for example, be ascertained by measuring how many non-Africans recognize the term Dark Continent versus the term Pan-African. A prevalence of familiarity with the former over the latter in public discourse or public consciousness would provide some insight on such imperial endurance.

The existence of rhetorical imperialism in Africa is not truly a question; rather, it is the presumption from which this study was launched, a presumption about history that 
also serves as the reason Scott Lyons' theory of rhetorical sovereignty exists in the first place. For the project here has not really been to trace the progression of imposed rhetoric of Africa from some starting place at the dawn of Abolition, but rather to backtrack from the present where such imposed rhetoric so vividly continues through familiarly historical terminology. Lyons' considerations of taking back control of terminology, characterizations, and writing that constructs one's identity for the public work within an understanding that such rhetoric has been seized and controlled by someone else before. But if the nuances of the history of that misplaced control and power are not pursued thoroughly, we run the risk of misplaced effort and of eventually striving to undo that which was not the problem in the first place. It is not merely enough to reject the terms that have been applied to one inappropriately; rather the goal must be to convince society to accept a change in terminology describing places or peoples. And to that end, the original terms imposed through rhetorical imperialism must be unpacked and the nature and complexity of their falsehood revealed as completely as possible, so that they can be replaced with accurate, authentic terminology, representation, and meaning.

To the extent therefore that this project has further revealed historical Anglophone rhetoric of Africa, it also hints at what might need to be contended with during efforts at rhetorical sovereignty, in terms of countering the residue of rhetorical imperialism. For example, while several scholars have identified and elaborated the rhetoric of the Dark Continent, efforts at rhetorical sovereignty will not succeed if those seeking to resist rhetorical imperialism merely argue against the premise that Africa unknown to Anglophone writers in the late- $19^{\text {th }}$ century. Equating dark with geographic ignorance is, 
as we know, a gross misunderstanding of the way Africa was perceived and constructed by Anglophone writers in the $19^{\text {th }}$ century; and so if all that is addressed in attempts at sovereignty is the issue of geography, polygenism remains uncontested. But even if polygenism is addressed, as Appiah has begun to do, such efforts only go a certain length towards addressing the earlier construction of Africa as fallen beneath Britain and America, all the while minimizing the ongoing practice of Anglophone writers viewing Africa as a blank slate to be constructed and described by themselves without guidance and mentoring by Africans themselves.

The latter is not a surprising revelation, of course. Given that this project has focused on moments of discovery - those first impressions in which Africa was originally perceived and conceived and subsequently related to others - it is not unreasonable to expect that writers in the midst of discovery would seize Africa rhetorically and construct it as they desired. That such explorers would repeatedly make the same move, however, of taking hold of the rhetoric of Africa and Africans through successive generations and across the Atlantic and back again is striking in how it reveals Anglophone writers' sense of pressures or expectations on them, or perhaps even a personal sense of entitlement, to imperialize Africa rhetorically.

Future work thus seems to fall along two lines. First, there is much rhetorical analysis and critique to be done on contemporary rhetoric of Africa - whether the critic is inclined to characterize it as ongoing imperialism or not. It continues to be far too easy for the $\mathrm{BBC}$, as a prime example, to characterize Africa using the old terminology without any sort of contestation or response. Second, there is a great deal more work to 
be done in the history of rhetoric of Africa, particularly in fleshing out what has been hinted at here.

For example, while I have argued for a rhetorical etymology of the notion of a dark Africa and attempted to suggest its origin and progression in an effort to track one specific sort of rhetorical imperialism with greater precision than has been done before, this project has certainly not accounted for a majority of the rhetorical imperialism carried out on Africa, even during the time period under scrutiny here. For example, there is the question of the way Africa and Africans were constructed rhetorically in the United States between independence and the founding of the ACS, or between the mid$19^{\text {th }}$-century evolutionary debates and the first decades after the Civil War. Additionally, there is a great deal of analysis to be done on the rhetoric of Liberia itself after 1823, both on a domestic U.S. track and within Liberia pre- and post-independence.

And the trove of unanalyzed writings of Sierra Leone, from The Times to the Colony's own newspapers to the vast corporate, Crown, and newly-arrived periodicals dating from the early-1800s through the $19^{\text {th }}$ century, to the explosion of travel narratives occasioned by Sierra Leone-from Mungo Park to Maria Falconbridge and numerous others - are ripe for rhetorical analysis and critique and would do much to build a more complete picture of what other rhetorics of Africa and Africans were brought about by way of Britain's first African colony.

While South Africa as a British settlement followed Sierra Leone and would not serve as an indicator of first British experiences in exploring or settling in Africa as Sierra Leone has here, it was a close second. The same genres of writing exist on South Africa, both domestically within Britain and within the colony itself; analyses that would 
reveal specific similarities and differences in the rhetoric of Africa and Africans can only help further to flesh out the portrait of Anglophone rhetorical imperialism towards Africa.

As British and American interests in Africa expanded, so too the library of exploration and discovery of which Stanley is only one-although one quite fittingly trans-Anglophone-example. A great deal of work remains to be done on the rhetoric of Stanley, Livingstone, Burton, and their contemporaries as well as on the explorations and discoveries of further parts of Africa as the $19^{\text {th }}$ century progressed. While the explorers' histories are increasingly being told, the way they constructed Africa and Africans for their readers in Britain and America and the trends of such rhetoric remains essentially untouched.

In terms of assessing the history of rhetorical sovereignty in resistance to rhetorical imperialism, a great deal of work awaits with the likes of Samuel Crowther, Martin Delany, and the countless other Africans or disaporants for whom these two have stood proxy here. A longitudinal study of Crowther in terms of the question of rhetorical sovereignty, for example, would allow the full arc of his career, from missionary understudy (pursued in this project) to fully consecrated Bishop, to inform the extent to which he eventually achieved sovereignty over his own representation. Such work could provide insight into the nature of efforts at sovereignty and the extent to which the individual's effort at control over identity can elicit change for the group.

The writings of Crowther and Delany refute previous arguments that either historical Africans or diasporants answered rhetoric of Africa with silence, but rather demonstrate the contributions as well as resistance writers of the Black Atlantic made to the rhetoric of Africa being constructed by writers of the White Atlantic. One of the most 
important areas of future work to be done is to expand our knowledge of specific Black Atlantic responses to the rhetorics of benighted Africa and the Dark Continent: for example, details of how African or diasporant writers reacted in the late-1870s and 1880s to the Dark Continent rhetoric —at the moment of its inception — would create a picture of historical rhetorical sovereignty, an inevitable field of study branching out from Lyons' initial concept as well as a logical parallel field to the study of historical rhetorical imperialism.

Methodologically speaking, other means of assessing the rhetoric of Africa are needed to create a more comprehensive picture of the rhetorical imperialism that has been achieved. For example, the more adjectival analysis in reference to Africa and Africans used here could easily be replaced with a more thematic approach, such as looking at trends of illness or of the peace/threat dichotomy and unpacking what lies beneath such tropes. A cartographic approach in terms of visual rhetoric - both the primacy of maps and the way prior maps were discarded, overlooked, or ignored or the way blankness was worked historically as a tool for entry—would find ample source material for exploring British and American rhetorical imperialism towards Africa through an altogether different lens. Or a generic approach that seeks rhetorical consistencies within categories of texts and attempts to discern what kinds of writings achieve what kinds of rhetorics about Africa would help in-and-of-itself to isolate what genres will be most useful for further work. And all of these tracks of research could be carried out in other languagespecific study, for the limitation of this study to Anglophone writers suggests just how small of a window into the rhetoric of Africa has been opened here. 
Last is perhaps the most important direction future work will need to continue to move, which is further back in time. While this project was limited to the Abolition-toBerlin-Conference period of exploration as a means of pragmatic containment, it began from stumbling several years ago upon a rhetoric - the trope of a benighted, degraded, fallen Africa - hitherto not critiqued, one that strikingly challenged the historiography of Anglophone inventions of Africa. The question of what came before-particularly what the precise rhetorics of Africa and Africans were in, say, the $17^{\text {th }}$ and $18^{\text {th }}$ centuriesremains a painful ignorance, one I can only hope will be relieved through efforts both by Rhetoric scholars taking an increasing interest in the history of rhetoric of Africa and by African Studies scholars seeing rhetoric as a useful if not essential tool for critiquing outsiders' engagement with Africa. 


\section{REFERENCES}

2012. Directed by Roland Emmerich. 2009. Culver City, CA: Sony Pictures, 2010. DVD.

Adeeko, Adeleke. "Writing Africa under the Shadow of Slavery: Quaque, Wheatley, and Crowther." Research in African Literatures 40, no. 4 (2009): 1-24. http://www.jstor.org/stable/40468159.

Adefarakan, Temitope. "'At a Crossroads': Spirituality and the Politics of Exile: The Case of the Yoruba Orisa." Obsidian 9, no. 1 (2008): 31-58.

Adeleke, Tunde. "Martin R. Delany's Philosophy of Education: A Neglected Aspect of African American Liberation Thought." Journal of Negro Education 63, no. 2 (1994): 221-36. http://www.jstor.org/stable/2967385.

Africa: Eye to Eye with the Unknown. 2013. London: BBC Home Entertainment, 2013. DVD.

Ajayi, J. F. A., and Michael Crowder. History of West Africa: Volume One. New York: Columbia University Press, 1972.

—. History of West Africa: Volume Two. New York: Columbia University Press, 1973.

Alie, Joe. A New History of Sierra Leone. New York: St. Martin's Press, 1990.

American Colonization Society. The Annual Reports of the American Society for Colonizing the Free People of Colour of the United States, Volumes 1-10, 181827. 1818-1910. Reprint, New York: Negro Universities Press, 1969.

-. The Annual Reports of the American Society for Colonizing the Free People of Colour of the United States, Volumes 11-20, 1828-36. 1818-1910. Reprint, New York: Negro Universities Press, 1969.

-. The Proceedings of a Public Meeting Held in the Middle Dutch Church. Together with Addresses Delivered on that Occasion by the Rev. Mr. Gallaudet, Principal of the Deaf and Dumb Asylum at Hartford, Connecticut, Captain Stockton, of the United States Navy, Francis S. Key, Esq. of the District of Columbia, and the Letters from Captain John B. Nicolson, of the United States Navy. New York: The Protestant Episcopal Press, 1829. 
Appiah, Kwame Anthony. In My Father's House: Africa in the Philosophy of Culture. New York: Oxford University Press, 1992.

Ashmun, Jehudi. Memoir of the Life and Character of the Rev. Samuel Bacon, A.M. Washington City (D.C.): Jacob Gideon, Jr.: 1822. http://hdl.handle.net/2027/uva.x002127356.

Bacon, Ephraim. Abstract of a Journal, E. Bacon, Assistant Agent of the United States, to Africa. Philadelphia: S. Potter, \& Co., 1821. http://hdl.handle.net/2027/loc.ark:/13960/t4km05g73.

Balsan, Francois. "Ancient Gold Routes of the Monomotapa Kingdom." The Geographic Journal 136, no. 2 (1970): 240-246. http://www.jstor.org/stable/1796283.

Bartlett, Robert. "Medieval and Modern Concepts of Race and Ethnicity." Journal of Medieval and Early Modern Studies 31, no. 1 (2001): 39-56.

Bent, Theodore. "On the Finds at the Great Zimbabwe (with a View to Elucidating the Origin of the Race that Built Them)." The Journal Anthropological Institute of Great Britain and Ireland 22 (1893): 123-136. http://www.jstor.org/stable/2842116.

Bhabha, Homi. The Location of Culture. 1994. Reprint, London: Routledge, 1998.

Bisson, Michael. "Trade and Tribute: Archaeological Evidence for the Origin of States in South Central Africa." Cahiers d'Études Africaines 22 (1982) 343-361. http://www.jstor.org/stable/4391813.

Blackett, Richard. "Martin R. Delany and Robert Campbell: Black Americans in Search of an African Colony." The Journal of Negro History 62, no. 1 (1977): 1-25. http://www.jstor.org/stable/2717188.

Bledsoe, Albert Taylor. "Liberty and Slavery." In Cotton is King, and Pro-slavery Arguments, edited by E.N. Elliott, 319-331. 1860. Reprint, New York: Negro Universities Press, 1969.

Blood Diamond. Directed by Edward Zwick. 2006. Burbank, CA: Warner Home Video, 2007. DVD.

Bourdain, Anthony. No Reservations. The Travel Channel. Season 2, Episode 10, September 3, 2006.

Braidwood, Stephen. Black Poor and White Philanthropists: London's Blacks and the Foundation of the Sierra Leone Settlement 1786-1791. Liverpool: Liverpool University Press, 1994. 
Brantlinger, Patrick. "Victorians and Africans: The Genealogy of the Myth of the Dark Continent." Critical Inquiry 12, no. 1 (1985): 166-203.

http://www.jstor.org/stable/1343467.

Brooks, Jr., George. “The Providence African Society's Sierra Leone Emigration Scheme, 1794-1795: Prologue to the African Colonization Movement." The International Journal of African Historical Studies 7, no. 2 (1974): 183-202. http://www.jstor.org/stable/217128.

Burgess, Ebenezer. Address to the American Society for Colonizing the Free People of Colour of the United States. At a Special Meeting, in the City of Washington, November 21 ${ }^{\text {st }}$, 1818. Washington: Davis and Force, 1818.

Burin, Eric. Slavery and the Peculiar Solution: A History of the American Colonization Society. Gainesville: University Press of Florida, 2005.

Campbell, James. "Redeeming the Race: Martin Delany and the Niger Valley Exploring Party, 1859-60." New Formations 45 (2002): 125-149.

Canagarajah, Suresh. Resisting Linguistic Imperialism in English Teaching. New York: Oxford University Press, 1999.

Carroll, Scott. "Solomonic Legend: The Muslims and the Great Zimbabwe." The International Journal of African Historical Studies 21, no. 2 (1988): 233-247. http://www.jstor.org/stable/219935.

Cartwright, Samuel. "Ethnology of the Negro or Prognathous Race." The Boston Medical and Surgical Journal 58, no 10 (1858): 1-15. http:// http://archive.org/details/101168906.nlm.nih.gov.

Chanaiwa, David. The Zimbabwe Controversy: A Case of Colonial Historiography. Syracuse: Program of Eastern Africa Studies, Maxwell School of Citizenship and Public Affairs, Syracuse University, 1973.

-. "Politics and Long-Distance Trade in the Mwene Mutapa Empire during the Sixteenth Century." The International Journal of African Historical Studies 5, no. 3 (1972): 424-435. http://www.jstor.org/stable/217093.

Chennells, Anthony. "Great Zimbabwe in Rhodesian Fiction." Matatu 34 (2007) 1-25. http://proquest.umi.com/pqdweb?did=0000001682730231.

Child, Lydia Maria. An Appeal in Favor of That Class of Americans Called Africans. Edited by Carolyn Karcher. 1833. Reprint, Amherst: University of Massachusetts Press, 1996. 
Chrisman, Laura. "The Imperial Unconscious? Representations of Imperial Discourse." Critical Quarterly 32, no. 3 (1990): 38-58. http://web.ebscohost.com.

Clapham, Christopher. Liberia and Sierra Leone: An Essay in Comparative Politics. Cambridge: Cambridge University Press, 1976.

Clay, Henry. "On African Colonization." In Speeches of the Hon. Henry Clay, of the Congress of the United States, 571-583. Cincinnati: Shepard \& Sterns, 1842.

Clegg, III, Claude. The Price of Liberty: African Americans and the Making of Liberia. Chapel Hill: University of North Carolina Press, 2004.

Cohen, Jefferey. "On Saracen Enjoyment: Some Fantasies of Race in Late Medieval France and England." Journal of Medieval and Early Modern Studies 31, no. 1 (2001): 113-146.

Coleman, Deirdre. "Sierra Leone, Slavery, and Sexual Politics: Anna Maria Falconbridge and the 'Swarthy Daughter' of Late 18th century Abolitionism." Women's Writing 2, no. 1 (1995): 3-23.

Coombes, Annie. Reinventing Africa: Museums, Material Culture and Popular Imagination in Late Victorian and Edwardian England. New Haven: Yale University Press, 1994.

Crane, Gregg. "The Lexicon of Rights, Power, and Community in Blake: Martin R. Delany's Dissent from Dred Scott.” American Literature 68, no. 3 (1996): 527-53. http://www.jstor.org/stable/2928243.

Crowther, Samuel. "Samuel Crowther's Narrative" In Journals of the Rev. James Frederick Schön and Mr. Samuel Crowther: Who, with the Sanction of Her Majesty's Government, Accompanied the Expedition up the Niger in 1841 on Behalf of the Church Missionary Society. By Schön, James Frederick, and Samuel Crowther, 371-385. 2nd ed. London: Cass, 1970.

Curtin, Philip D. "Review: Swing Low, Sweet Chariot: The Mortality Cost of Colonizing Liberia in the Nineteenth Century by Antonio McDaniel." The Journal of Interdisciplinary History 27, no. 3 (1997): 558-560. http://www.jstor.org/stable/205958.

-. The Image of Africa: British Ideas and Action, 1780-1850. Madison: University of Wisconsin Press, 1964.

Darwin, Charles. On the Origin of Species. London: John Murray, 1859.

—. The Descent of Man. London: John Murray, 1871. 
Delany, Martin Robison. The Condition, Elevation, Emigration, and Destiny of the Colored People of the United States; and, Official Report of the Niger Valley Exploring Party. 1852, 1861. Reprint, Amherst, N.Y.: Humanity Books, 2004.

Derricourt, Robin. Inventing Africa: History, Archaeology and Ideas. London: Pluto Press, 2011.

Desai, Gaurav. Subject to Colonialism: African Self-Fashioning and the Colonial Library. Durham: Duke University Press, 2001.

Dew, Thomas Roderick. "Abolition of Negro Slavery." In Cotton is King, and Proslavery Arguments, edited by E.N. Elliott, 21-70. 1860. Reprint, New York: Negro Universities Press, 1969.

Dworkin, Ira. "In the Country of My Forefathers." Atlantic Studies 5, no. 1 (2008): 99118. doi: $10.1080 / 14788810701878291$.

Egerton, Douglas. "Review: An African Republic: Black and White Virginians in the Making of Liberia by Marie Tyler-McGraw." American Studies 48, no. 4 (2007): 159-60. doi: 10.1353/ams.0.0014.

Elliott, E.N. Introduction to Cotton is King, and Pro-slavery Arguments, edited by E.N. Elliott. 1860. Reprint, New York: Negro Universities Press, 1969.

Everill, Bronwen. Abolition and Empire in Sierra Leone and Liberia. Hampshire: Palgrave Macmillan, 2012.

-. "Bridgeheads of Empire? Liberated African Missionaries in West Africa." The Journal of Commonwealth History 40, no. 5 (2012): 789-805. doi: $10.1080 / 03086534.2012 .730833$.

Falconbridge, Anna Maria. Narrative of Two Voyages to the River Sierra Leone During the Years 1791-1792-1793. Edited by Christopher Fyfe. Liverpool: Liverpool University Press, 2000.

Falola, Toyin. Introduction to The Condition, Elevation, Emigration, and Destiny of the Colored People of the United States; and, Official Report of the Niger Valley Exploring Party. Martin Robison Delany. Amherst, N.Y.: Humanity Books, 2004.

Ferguson, Moira. "Anna Maria Falconbridge and the Sierra Leone Colony: 'A Female Traveller in Conflict."' Lumen: Selected Proceedings from the Canadian Society for Eighteenth-Century Studies 16 (1997): 1-24. doi: 10.7202/1012436ar.

Ficke, Herman. “The Source of Rider Haggard's 'She.” Studies in English 6 (1926): 178-180. http://www.jstor.org/stable/20779374. 
Fitzhugh, George. "Sociology for the South; or the Failure of Free Society." In A House Divided: The Antebellum Slavery Debates in America, edited by Mason Lowance, 132-135. Princeton: Princeton University Press, 2003.

—. Cannibals, All! Richmond: A. Morris, 1857. http://books.google.com.

Fontein, Joost. The Silence of Great Zimbabwe: Contested Landscapes and the Power of Heritage. Oxon and New York: University College London Press, 2006.

Foster, Charles. "The Colonization of Free Negroes, in Liberia, 1816-1835." The Journal of Negro History 38, no. 1 (1953): 41-66. http://www.jstor.org/stable/2715813.

Fyfe, Christopher. A History of Sierra Leone. 1962. Reprint, London: Oxford University Press, 1962.

-. "Maryland in Liberia." The Journal of African History 12, no. 4 (1971): 671-72. http://www.jstor.org/stable/181029.

—. Sierra Leone Inheritance. London: Oxford University Press, 1964.

Garrison, William Lloyd. "Exposure of the American Colonization Society." In Selections from the Writings and Speeches of William Lloyd Garrison, 13-25. 1852. Reprint, New York: Negro Universities Press, 1954.

—. Thoughts on African Colonization. 1832. Reprint, New York: Arno Press, 1968.

George, Katherine. "The Civilized West Looks at Primitive Africa: 1400-1800, a Study in Ethnocentrism." ISIS 49, no. 1 (1958): 62-72.

http://www.jstor.org/stable/226605.

Gilroy, Paul. The Black Atlantic: Modernity and Double Consciousness. Cambridge, Massachusetts: Harvard University Press, 1993.

Griffin, Francis. "Henry Smeathman [?-1786]." The Proceedings of the Royal Entomological Society of London. Series A, General Entomology 17, no. 1-3 (1942): 1-9.

Grimke, Angelina. Appeal to the Christian Women of the South. New York: New York Anti-Slavery Society, 1836.

Haggard, H. Rider. Preface to Monomotapa (Rhodesia). Alexander Wilmot. London: T. Fisher Unwin, 1896. http://books.google.com/.

—. King Solomon's Mines. London: Cassell and Company, 1885. 
—. She, a History of Adventure. London: Longmans, Green, 1887.

Hahn, Thomas. "The Difference the Middle Ages Makes: Color and Race Before the Modern World." Journal of Medieval and Early Modern Studies 31, no. 1 (2001): $1-37$.

Hall, Martin. "The Legend of the Lost City: Or, the Man with Golden Balls." Journal of Southern African Studies 21, no. 2 (1995): 179-199. http://www.jstor.org/stable/2637020.

Hall, Martin and J.C. Vogel. "Some Recent Radiocarbon Dates from Southern Africa." The Journal of African History 21, no. 4 (1980): 431-455. http://www.jstor.org/stable/182003.

Haller, Jr., John. Outcasts from Evolution: Scientific Attitudes of Racial Inferiority, 1859-1900. Urbana: University of Illinois Press, 1971.

Hammond, Dorothy and Alta Jablow. The Africa that Never Was: Four Centuries of British Writing about Africa. 1970. Reprint, Prospect Heights, IL: Waveland Press, 1992.

Harper, William. "Memoir on Slavery." In Cotton is King, and Pro-slavery Arguments, edited by E.N. Elliott, 78-135. 1860. Reprint, New York: Negro Universities Press, 1969.

Harris, Stephen. "The Election of the Angles." In Race and Ethnicity in Anglo-Saxon Literature, 45-82. New York: Routledge, 2003.

Haskett, Norman. "Afro-American Images of Africa: Four Antebellum Black Authors." Ufahamu: Journal of the African Activist Association 3, no. 1 (1972): 29-40.

Hastings, Adrian. "Christian Life in the Age of Bishop Crowther." In The Church in Africa: 1450-1950. Oxford: Oxford University Press, 1996. 338-395.

Hill, Adelaide Cromwell, and Martin Kilson. Apropos of Africa: Sentiments of Negro American Leaders on Africa from the 1800s to the 1950s. London: Cass, 1969.

Howard, Allen. "Nineteenth-Century Coastal Slave Trading and the British Abolition Campaign in Sierra Leone." Slavery and Abolition 27, no. 1 (2006): 23-49. doi: 10.1080/01440390500499893.

Huigen, Siegfried. "Travellers to Monomotapa: The Representation of Southern Africa by the Dutch in the Seventeenth Century." History and Anthropology 9, no. 2-3 (1996): 207-230. doi: 10.1080/02757206.1996.9960878. 
- "Natural History and the Representation of South Africa in the Eighteenth Century." Journal of Literary Studies 14, nos. 1-2 (1998): 67-79. doi: $10.1080 / 02564719808530189$.

Hurlbut, George. "Geographical Notes." Journal of the American Geographical Society of New York 24 (1892): 391-450. http://www.jstor.org/stable/196706.

Hutton, Frankie. "Economic Considerations in the American Colonization Society's Early Effort to Emigrate Free Blacks to Liberia, 1816-1836." The Journal of Negro History 68, no. 4 (1983): 376-389. http://www.jstor.org/stable/2717564.

Huxley, Thomas. Evidence as to Man's Place in Nature. London: Williams and Norgate, 1863.

Jarosz, Lucy. "Constructing the Dark Continent: Metaphor as Geographic Representation of Africa." Geografiska Annaler. Series B, Human Geography 74, no. 2 (1992): 105-115. http://www.jstor.org/stable/490566.

Jones-Royster, Jacqueline. "When the First Voice you Hear is Not Your Own." In Cross Talk in Comp Theory: A Reader, Second Edition, edited by Victor Villanueva, 555-566. Urbana, IL: NCTE, 2003.

Kachru, Braj. The Other Tongue: English Across Cultures. New York: Oxford University Press, 1982.

Kahn, Robert. "The Political Ideology of Martin Delany." Journal of Black Studies 14, no. 4 (1984): 415-440. http://www.jstor.org/stable/2784084.

Kass, Amalie. "Dr. Thomas Hodgkin, Dr. Martin Delany, and the 'Return to Africa."' Medical History 27, no. 4 (1983): 373-393. www.ncbi.nlm.nih.gov.

Kass, Amalie, and Edward Kass. "Doctors Afield: Martin Delany, Thomas Hodgkin, and the Black Nationalist Movement." The New England Journal of Medicine 305, no. 12 (1981): 682-84.

Kazanjian, David. “The Speculative Freedom of Colonial Liberia.” American Quarterly 63, no. 4 (2011): 863-893. doi: 10.1353/aq.2011.0059.

Kelly, Kathleen Ann. “"Blue' Indians, Ethiopians, and Saracens in Middle English Narrative Texts," Parergon 11, no. 1 (1993): 35-52.

Killingray, David. "Sierra Leone Settlers." The Journal of African History 36, no. 3 (1995): 507-08. http://www.jstor.org/stable/182480.

Kup, A. P. "John Clarkson and the Sierra Leone Company." The International Journal of African Historical Studies 5, no. 2 (1972): 203-220. 
http://www.jstor.org/stable/217514.

—. Sierra Leone: A Concise History. New York: St. Martin's Press, 1975.

—. A History of Sierra Leone, 1400-1787. 1961. Reprint, London: Cambridge Univ. Press, 1962.

Land, Isaac, and Andrew Schocket. "New Approaches to the Founding of the Sierra Leone Colony, 1786-1808." Journal of Colonialism and Colonial History 9, no. 3 (2008): n.p. doi: 10.1353/cch.0.0021.

Leaver, David. "Great Zimbabwe: Colonial Historiography.” In Encyclopedia of African History, Vol. 1, edited by Kevin Shillington, 1022-1024. New York: Routledge, 2004.

Liebenow, J. Gus. Liberia: The Quest for Democracy. Bloomington: Indiana University Press, 1987.

Livingstone, David. The Last Journals of David Livingstone, in Central Africa. London: John Murray, 1874. http://books.google.com.

Livingstone, David and Charles Livingstone. Narrative of an Expedition to the Zambesi and its Tributaries. London: John Murray, 1865. http://books.google.com.

Lovejoy, Paul. "The Children of Slavery -- the Transatlantic Phase." Slavery and Abolition 27, no. 2 (2006): 197-217. doi: 10.1080/01440390600765524.

Lubbock, John. "The Origin of Civilisation and the Primitive Condition of Man." Transactions of the Ethnological Society of London 6 (1868): 328-341. http://www.jstor.org/stable/3014269.

Lyons, Scott. "Rhetorical Sovereignty: What Do American Indians Want from Writing?" College Composition and Communication 51, no. 3 (2000): 447-68. http://www.jstor.org/stable/358744.

Matthews, John. A Voyage to the River Sierra-Leone, on the Coast of Africa. London: B. White and Son, 1791. www.books.google.com.

McKenzie, P.R. Inter-religious Encounters in West Africa: Samuel Ajayi Crowther's attitude to African Traditional Religion and Islam. Leicester, UK: University of Leicester Study of Religion Sub-Department, 1976.

McLaughlan, Robbie. Re-imagining the 'Dark Continent' in fin de siécle Literature. Edinburgh: Edinburgh University Press, 2012.

McNaughton, David. "A Possible Semitic Origin for Ancient Zimbabwe." The Mankind Quarterly LII, nos. $3 \& 4$ (2012): 323-335. http://www.dlmcn.com. 
Meacham, Standish. Henry Thornton of Clapham, 1760-1815. Cambridge: Harvard University Press, 1964.

Miller, Floyd J. The Search for a Black Nationality: Black Emigration and Colonization, 1787-1863. Urbana: University of Illinois Press, 1975.

Mouser, Bruce. "Trade, Coasters, and Conflict in the Rio Pongo from 1790-1808." The Journal of African History 14, no. 1 (1973): 45-64.

http://www.jstor.org/stable/180776.

Mudimbe, V.Y. The Invention of Africa: Gnosis, Philosophy, and the Order of Knowledge. Bloomington: Indiana University Press, 1988.

Muhlenberg, William Augustus. A Sermon in Memory of the Rev. Samuel Bacon, and John P. Bankson, Agents of the United States, Under the Direction of the American Colonization Society. Philadelphia: Clark \& Raser, 1820.

Murphy, Laura. "Obstacles in the Way of Love: The Enslavement of Intimacy in Samuel Crowther and Ama Ata Aidoo." Research in African Literatures 40, no. 4 (2009): 47-64. http://www.jstor.org/stable/40468161.

Ngugi, Wa Thiong'O. Decolonising the Mind: The Politics of Language in African Literature. Oxford: Heinemann, 1986.

Northrup, David. "Becoming African: Identity formation among liberated slaves in nineteenth-century Sierra Leone." Slavery and Abolition 27, no. 1 (2006): 1-21. doi: 10.1080/01440390500499794.

Nott, Josiah. "The Natural History of the Caucasian and Negro Races." In Cotton is King, and Pro-slavery Arguments, edited by E.N. Elliott, 208-238. 1860. Reprint, New York: Negro Universities Press, 1969.

Nott, Josiah and George Gliddon. Types of Mankind. Philadelphia: Lippincott, Grambo \& Co., 1854.

Nwankwo, Ifeoma. "The Promises and Perils of US African-American Hemispherism: Latin America in Martin Delany's Blake and Gayl Jones's Mosquito." American Literary History 18, no. 3 (2006): 579-599. doi: 10.1093/alh/aj1013.

Ogunleye, Tolagbe. "Dr. Martin Robison Delany, $19^{\text {th }}$-Century Africana Womanists: Reflections on His Avant-Garde Politics Concerning Gender, Colorism, and Nation Building." Journal of Black Studies 28, no. 5 (1998): 628-649. http://www.jstor.org/stable/2784798. 
Park, Mungo. Travels in the Interior Districts of Africa. 1799. Reprint, edited by Kate Marsters. Durham: Duke University Press, 2000.

Paul, Heike. "Out of Chatham: Abolitionism on the Canadian Frontier." Atlantic Studies 8, no. 2 (2011): 165-88.

Pennycook, Alastair. English and the Discourses of Colonialism. London: Routledge, 1998.

Phillipson, Robert. Linguistic imperialism. Oxford: Oxford University Press, 1992.

Pinderhughes, Charles. "Toward a New Theory of Internal Colonialism." Socialism and Democracy 25, no. 1 (2011): 235-256. doi: 10.1080/08854300.2011.559702.

Pratt, Mary Louise. Imperial Eyes: Travel Writing and Transculturation. London: Routledge, 1991.

Randall-MacIver, David. Mediaeval Rhodesia. 1906. Reprint, London: Cass, 1971.

Reade, Winwood. Savage Africa. London: Smith, Elder and Co., 1863. http://books.google.com.

Reid, Mandy. "Utopia Is in the Blood: The Bodily Utopias of Martin R. Delany and Pauline Hopkins." Utopian Studies 22, no. 1 (2011): 91-103. doi: 10.5325/utopianstudies.22.1.0074.

Richards, Thomas. Samuel J. Mills Missionary Pathfinder, Pioneer and Promoter. Boston: The Pilgrim Press, 1906. http://www.archive.org/details/cu31924051258410.

Rosenfeld, Louis. "Martin Robison Delany (1812-1885): Physician, Black Separatist, Explorer, Soldier." Bulletin of the New York Academy of Medicine 65, no. 7 (1989): 801-818. www.ncbi.nlm.nih.gov.

Russett, Cynthia. Sexual Science: The Victorian Construction of Womanhood. Cambridge: Harvard University Press, 1989.

Ryan, Susan. "Errand into Africa: Colonization and Nation Building in Sarah J. Hale's Liberia." The New England Quarterly 68, no. 4 (1995): 558-583. http://www.jstor.org/stable/365875.

Said, Edward. Orientalism. 1978. New York: Vintage, 1994.

Sawyerr, Harry. "Christian Evangelistic Strategy in West Africa: Reflections on the Centenary of the Consecration of Bishop Samuel Adjayi Crowther on St. Peter's Day, 1864." International Review of Missions 54, no. 215 (1965): 343-352. 
Schama, Simon. Rough Crossings: Britain, the Slaves and the American Revolution. London: BBC Books, 2006.

Schmidt, Peter and Jonathan Walz. "Re-Representing African Pasts through Historical Archaeology." American Antiquity 72, no. 1 (2007): 53-70.

http://www.jstor.org/stable/40035298.

Schön, James Frederick, and Samuel Crowther. Journals of the Rev. James Frederick Schön and Mr. Samuel Crowther: who, with the sanction of Her Majesty's Government, accompanied the expedition up the Niger in 1841 on behalf of the Church Missionary Society. 2nd ed. London: Cass, 1970.

Sharpe, Jenny. "The Middle Passages of Black Migration.” Atlantic Studies 6, no. 1 (2009): 97-112. doi: 10.1080/14788810802696311.

Shaw, Ibrahim Seaga. "The Politics of Humanitarian Intervention: a Critical Analogy of the British Response to End the Slave Trade and the Civil War in Sierra Leone." Journal of Global Ethics 6, no. 3 (2010): 273-285.

Shelby, Tommie. "Two Conceptions of Black Nationalism: Martin Delany on the Meaning of Black Political Solidarity." Political Theory 31, no. 5 (2003): 664-692. http://www.jstor.org/stable/3595691.

Shick, Tom. Behold the Promised Land: A History of Afro-American Settler Society in Nineteenth-Century Liberia. 1980. Reprint, Baltimore: The Johns Hopkins University Press, 1977.

-. "A Quantitative Analysis of Liberian Colonization from 1820 to 1843 with Special Reference to Mortality." The Journal of African History 12, no. 1 (1971): 45-59. http://www.jstor.org/stable/180566.

Siegfried, Huigen. "Travellers to Monomotapa: The Representation of Southern Africa by the Dutch in the Seventeenth Century." History and Anthropology 9, no. 2-3 (1996): 207-230. doi: 10.1080/02757206.1996.9960878.

Smeathman, Henry. Some Account of the Termites Which Are Found in Africa and Other Hot Climates. London: J. Nichols, 1781.

-. Plan of a Settlement to be Made Near Sierra Leone on the Grain Coast of Africa. London: T. Stockdale, 1786.

Smith, Ian. The Great Betrayal: The Memoirs of Ian Douglas Smith. London: John Blake Publishing, 1997.

Smith, James Wesley. Sojourners in Search of Freedom: The Settlement of Liberia by 
Black Americans. Lanham, MD: University Press of America, 1987.

Spring, Gardiner. A Memoir of Samuel John Mills, Second Edition. Boston: Perkins \& Marvin: 1829. http://books.google.com/.

Stanley, Henry. How I Found Livingstone in Central Africa. 1872. Reprint of 1895 Edition, Mineola: Dover Publications, 2001.

—. Through the Dark Continent, Volume I. 1878. Reprint of 1899 Edition, New York: Dover Publications, 1988.

—. Through the Dark Continent, Volume II. 1878. Reprint of 1899 Edition, New York: Dover Publications, 1988.

Staudenraus, P. J. The African Colonization Movement, 1816-1865. New York: Columbia University Press, 1961.

Stein, Jordan Alexander. “'A Christian Nation Calls for its Wandering Children': Life, Liberty, Liberia.” American Literary History 19, no. 4 (2007): 849-873. doi: 10.1093/alh/ajm036.

Stiebel, Lindy. "Creating a Landscape of Africa: Baines, Haggard and Great Zimbabwe." English in Africa 28, no .2 (2001): 123-133. http://www.jstor.org/stable/40238934.

Stocking, George. Victorian Anthropology. New York: The Free Press, 1987.

Substance of the Report of the Court of Directors of the Sierra Leone Company to the General Court, Held at London On Wednesday the 19th of October, 1791. London: James Philips, 1791.

Tangri, Daniel. "Popular Fiction and the Zimbabwe Controversy." History in Africa 17 (1990): 293-304. http://www.jstor.org/stable/3171818.

The Black Presence Exhibition. The National Archives (UK). Accessed 7 October 2012. http://www.nationalarchives.gov.uk/pathways/blackhistory/work_community/poo r.htm.

“The Dark Continent.” Nature 18, no. 450 (13 June 1878): 175-179. doi: $10.1038 / 018175 \mathrm{a} 0$.

The National Archives. "Work and community." The Black Presence Exhibition. http://www.nationalarchives.gov.uk/pathways/blackhistory/work_community/poo r.htm.

“The Royal Gazette - Sierra Leone 1808-1810 / 1817-1827." Government Publications 
Relating to Sierra Leone 1808-1961. Government Publications Relating to Africa in Microform Series, Microform Academic Publishers, West Yorkshire, UK, Group One 1808-1865, Reel 8, 1967.

The Times (London). "Sierra Leona," 26 November 1792.

-. "Sierra Leona Bill," 4 May 1791, 2B.

—. "Sierra Leona Bill," 13 May 1791, 2C.

—. "Sierra Leona Bill," 18 May 1791 2B.

—. "Sierra Leone," 17 May 1791, 3A.

—. "Sierra Leone Bill,” 24 May 1791, 2 D.

—. "Sierra Leone Bill," 31 May 1791, 2B.

—. "Sierra Leone Company," 10 February 1792, 3D.

—. "Sierra Leone House," 11 July 1792, 3B.

—. "Sierra Leone House," 24 August 1792, 4A.

—. "Sierra Leone House," 4 December 1792, 3B.

—. "Sierra Leone House, Dec. 24.," 28 December 1795, 4A.

-. n/t, 26 January 1792, 3B.

—. n/t, 6 February 1792, 3B.

-. n/t, 3 September 1792, $2 \mathrm{D}$.

Van Sickle, Eugene. "Reluctant Imperialists: The U.S. Navy and Liberia, 1819-1845." Journal of the Early Republic 31, no. 1 (2011): 107-134. doi: 10.1353/jer.2011.0007.

Walker, David. David Walker's Appeal, in Four Articles; Together with a Preamble to the Coloured Citizens of the World, but in Particular, and Very Expressly, to Those of the United States of America. Edited by Sean Wilentz. 1829. Reprint, New York: Hill and Wang, 1995.

Walls, Andrew. "Black Europeans, White Africans: Some Missionary Motives in West Africa." Religious Motivation, Biographical and Sociological Problems for the Church Historian 15 (1978): 339-48. 
-. "The Legacy of Samuel Ajayi Crowther." International Bulletin of Missionary Research 16, no. 1 (1992): 15-21. http://search.proquest.com/docview/1299971112?accountid=14665.

Wilmot, Alexander. Monomotapa (Rhodesia). London: T. Fisher Unwin, 1896. http://books.google.com/.

Wilson, Charles Morrow. Liberia: Black Africa in Microcosm. New York: Harper \& Row, 1971.

Wilson, Ellen Gibson. The Loyal Blacks. New York: Capricorn Books, 1976.

Wiltberger, Christian. Diary, 21 January - 31 December 1821. Microfilm Collection, Acc. \# MSS 17078, Library of Congress, 1977.

Winterbottom, Thomas. An Account of the Native Africans in the Neighbourhood of Sierra Leone, Volume I. 1803. Reprint, London: Frank Cass and Co. Ltd., 1969. 
Department of English

11802 Squires Lane

University of Louisville

Louisville, KY 40223

Louisville, KY 40292

(502) 471-0107

dpmaha1@louisville.edu

\section{Education}

Ph.D. in Rhetoric and Composition, August 2013

University of Louisville

Dissertation: "The Rhetoric of Africa: Historical Turns in Constructing a Continent, 1780-1890."

Committee: Carol Mattingly (Director), Glynis Ridley, Beth Willey, Stephen Schneider, Wyatt MacGaffey

M.A. in English, August 1998

Bread Loaf School of English

Specializations in Nature Writing with John Elder and Elizabethan Drama with Emily Bartels and John Wilders

B.A. in Sociology/Anthropology, May 1993

Middlebury College

Minor in Classical Civilization

\section{Dissertation:}

This project focuses on the history of rhetoric during the transitional period between the Abolition era and the formal period of colonization, as witnessed in English language writings, both British and American. As a model for rhetorical analysis, the project scrutinizes primary source documents from the founding of the Sierra Leone and Liberia colonies through the travel writings of early, to the discovery of Great Zimbabwe with an eye to the way Africans and Africa are characterized rhetorically. In this period, English language rhetorics shift from constructing Africans and Africa inconsistently, ambivalently, or even positively, to casting them as benighted or fallen from grace, and lastly to constructing them as utterly and always dark. Through tracing the arc of this rhetorical narrative, the project considers the limits of rhetorical imperialism on rhetorical sovereignty. 


\section{Teaching and Administrative Experience:}

Graduate Teaching Assistant, University of Louisville, 2011-2012

First Year Composition, Professional Writing

Director of Diversity and Global Studies, Kentucky Country Day School, Louisville, KY, 2007-present: Coordinator for extensive programming and development in Multiculturalism, Diversity, and Global Studies

o Ghana Sister School Program, Tamale, Ghana: Established and formalized Sister School cultural and educational exchange between students and faculty at Tamale Islamic Science Secondary School (TISSEC) and Dahin Sheli Primary/Junior High School. Hosted Tamale delegations in Louisville, including the President of Ghana, the former Vice President of Ghana, and the Metro Chief Executive of Tamale. Created and managed strategic partnerships with Colwod Women's Cooperative, Shekinah Clinic, Tamale Scholarship and Aid Fund, Sister Cities International/The Gates Foundation, and Healing the Children/Rotary International

o Argentina Sister School Program, La Plata, Argentina: Established and formalized yearly month-long reciprocal Sister School cultural and educational exchanges with the School for Fine Arts and Lincoln Academy

o Jiujiang Sister School/Cultural Studies Program, Jiujiang, China: Established student and faculty reciprocal exchanges on trips, online exchange, instructional exchange

o Emerging Haiti Service/Cultural Exchange Program, starting June 2013 with student/faculty service trip, based on and extending prior Earthquake Relief efforts

o Diversity Programs: Development of student affinity groups, annual regional Middle School Students of Color Conference and High School Students of Color and Diversity Conference, recent visits of Hamza Yusuf, Simon Ortiz, Vice President Aliu Mahama, symposiums on interfaith relations, faculty/staff diversity forum, faculty cultural competency training, extensive public and private sector community partnerships in support of programming

o Teaching of term courses in African Literature, Arabic Literature, East Asian Literature, and Creative Writing

English Instructor, Waynflete School, Portland, Maine, 2006-07

African Literature; Introduction to Literature and Writing

English Instructor, Carolina Day School, Asheville, North Carolina, 2003-06 African Literature, Arabic Literature, and East Asian Literature

English Instructor, Steamboat Springs High School, Steamboat Springs, Colorado, 2002-03 America Literature, World Literature Editor of student and faculty literary journal

Adjunct Faculty, Whatcom Community College, Bellingham, Washington, 2001 First Year Composition, Introduction to Literature 
English Instructor, Kentucky Country Day School, 1998-2001

World Literature, Introduction to Literature and Writing

Editor of student and faculty literary journal

Founder and Director of Kentucky Author in Residence Series

English Instructor, Sayre School, Lexington, Kentucky, 1995-98

American Literature, Introduction to Literature and Writing

History and Drama Teacher, Palm Valley School, Rancho Mirage, California, 1994-95

Dean of Students and Founding Faculty, Summerbridge /The Breakthrough Collaborative, Louisville, Kentucky, 1992, 1993

\section{Publications:}

"A School Community Rises to the Challenge." In Water \& Its Spiritual Significance. Edited by Elena Lloyd-Sidle and Gray Henry-Blakemore. Louisville, KY: Fons Vitae Press, 2010.

“The Power Broker: Robert Kennedy, Jr.” Canoe and Kayak. March 2007

"Good Company: Paddling-related businesses banking on a cleaner planet." Canoe and Kayak. March 2007.

“Buyer’s Guide.” Paddler, January/February 2007.

“Essex Industries: Good Products and Deeds.” Paddlesports Business. Winter 2006.

"Straight Jacket: Wrestling with the Mandatory PFD Use Issue." Paddle Dealer. Spring 2004.

“The 10 All-time Greatest Sea Kayaking Expeditions.” Paddler. April 2003.

“Mission Statement.” Mountain Hardwear. Spring 2003.

Nut News. Mountain Hardwear. 2002-2003.

"Vermont Yankee Reactor." Nuclear Choices: A Citizen’s Guide to Nuclear Technology. MIT Press, 1993.

"Review: Desirable Daughters by Bharati Mukherjee." The Steamboat Local. September 3, 2002.

"Review: Brown: The Last Discovery of America by Richard Rodriguez." The Steamboat Local. November 10, 2002. 
“'The Story of Miss Li': Uncommon Ground: Morality Tales Across Cultures." Indiana University East Asian Studies Center. 2001.

“Review: Akhenaten, Dweller in Truth by Naguib Mahfouz.” LEO Weekly. April 2000.

“An Interview with Sena Jeter Naslund, author of Ahab's Wife." LEO Weekly. September 1999.

Extensive portfolio includes dozens of further publications in Canoe and Kayak, Paddlesports Business, Paddler, Paddle Dealer, The Steamboat Springs Local, and LEO Weekly, since 1998, all available upon request.

\section{Conference Presentations:}

"Samuel Crowther and the Limits of Rhetorical Sovereignty in the Transnational African Experience." African Literature Association Conference, Charleston, South Carolina. March 2013.

"What does the Test Test? Official Language Policy Rhetorics, Local Language Practices, and Africa's Translingual Models for English in the World." African Studies Association Conference, Philadelphia, Pennsylvania, November 2012.

"Learning from Ghanaian English Composition: An Argument for Empathy in Translingual Ecology." Thomas R. Watson Conference on Rhetoric and Composition. Louisville, KY, October 2012.

"Linguistic and Rhetorical Sovereignty as a Human Right: the Occasion of Englishes in Abina and the Important Men.” African Literature Association, Dallas, Texas, April 2012.

"War and Peace Commodified: Writing the Peace and Stability Operations Industry into Existence.” Kentucky Philological Association Conference, Morehead, Kentucky, March 2012.

"The Power and Place of Affinity Groups in Institutional Recruitment and Retention of Diversity." Bellarmine University Dialogue on Diversity Conference, Louisville, Kentucky, November 2011.

"Driving Blind but Getting Somewhere: African Literature in the Secondary Setting" (with Lowell Libby). African Literature Association Conference, Morganton, West Virginia, March, 2007.

"Contemporary African Literature" and "Contemporary Arabic Literature," North Carolina English Teachers Association Annual Conference, High Point, North Carolina, September 2005 
"Contemporary World Literature," North Carolina Association of Independent Schools Annual Conference, Charlotte, North Carolina, November 2004

"Contemporary World Literature," North Carolina English Teachers Association Annual Conference, Charlotte, North Carolina, September 2004

\section{Fellowships and Awards:}

Cox Family Foundation Grant 2012-13: for research of multilingual education pedagogy in primary and secondary education in Ghana

World Affairs Council Global Visionary Award, December 2010

Bill and Melinda Gates Foundation/Sister Cities International African Urban Poverty Alleviation Program Grant, 2009 (grant co-author and director, 2009)

Fortnight Grant: for attendance of Sister Cities International Conference, Belfast, Northern Ireland, 2009

Zoo Press Poetry Prize Honorable Mention for the collection An Agreement with Gravity, 2002

Teaching East Asian Literature in the High School Classroom Grant, Indiana University East Asian Studies Center, 2001-02

Eric David Memorial Award for Excellence in Teaching, 1999

Short Award for Excellence in Teaching, 1997

Stories in the Land Teaching Grant, Orion Society, 1996-97

Orion Society Fellowship, Bread Loaf School of English, 1996

\section{Related Activiy}

Founder and Coordinator, Kentucky Association of Independent Schools Diversity Consortium

Tamale Committee, Sister Cities of Louisville, 2007-present. Committee Co-Chair and SCL Board Member, 2009

Board Member, Arcadia Community Center, Louisville, Kentucky, 2007-2008.

Sister Cities speech to the Vice President of Ghana, Louisville, Kentucky, November 2009

Louisville delegate to Sister Cities International 2009 Conference, Belfast, Ireland 
Board of Directors, North Carolina English Teachers Association (NCTE affiliate), 2005

Teaching East Asian Literature in the High School Summer Workshop, East Asian Studies Center, Indiana University, July 2001

\section{Teaching Competencies:}

Colonial and Post-Colonial Rhetoric, Visual Rhetoric, British Colonial Rhetoric, African Literature, Arab and Middle Eastern Literature, East Asian Literature, Post-Colonial Theory, $20^{\text {th }}$ Century American Literature, Introduction to Literature, Business and Technical Writing, First Year Composition, Creative Writing (poetry and short and long fiction), Print and Web Journalism, Public Relations Writing.

\section{Areas of Interest:}

Historical Rhetorics, New Rhetorical Models for Archival Analysis, Archival Research, Emerging Global Literature, Citizen Diplomacy Intersections between Government and Education, Sister Cities, Public Sector Collaboration with Non-Profit Volunteerism, Humanitarianism and Aid Best Practices, NGO and Non-Profit Best Practices and Implementation, Global Studies and International Classroom and Student Exchange, Diversity Pedagogy, Program, and Practice, Interfaith Dialogue and Collaboration, Northern Ghana.

\section{Research Competencies:}

Coursework: Qualitative Research Theory, Methods, and Analysis, including field research project; Applied Statistics. Dissertation research in online and physical archival materials. Professional journalistic research experience. 